UNIVERSIDADE DE SÃO PAULO

FACULDADE DE FILOSOFIA, LETRAS E CIÊNCIAS HUMANAS

DEPARTAMENTO DE SOCIOLOGIA

PROGRAMA DE PÓS-GRADUAÇÃO EM SOCIOLOGIA

\title{
"TERCEIRA IDADE" E CIDADE: O ENVELHECIMENTO POPULACIONAL NO ESPAÇO INTRA-URBANO DE SANTOS
}

Juliana Andrade Oliveira

Dissertação apresentada ao Programa de Pós-Graduação em Sociologia, do Departamento de Sociologia da Faculdade de Filosofia, Letras e Ciências Humanas da Universidade de São Paulo, para obtenção do título de Mestre em Sociologia.

Orientador: Prof. Dr. Mario Antonio Eufrásio

São Paulo

2006 
Aos meus pais. 


\section{AGRADECIMENTOS}

Creio que nunca encontrarei palavras suficientes para expressar a gratidão e o sentimento terno e feliz de saber que pude contar com pessoas tão boas nessa fase da minha vida.

Este trabalho é um sonho meu e de outras almas e agradeço a elas e a Deus por terem me ajudado a realizá-lo. Muitas pessoas queridas - e surpreendentemente outras não tão próximas - foram decisivas para que essa dissertação viesse a existir. Verdadeiros anjos e fadas madrinhas indicaram-me o caminho e ampararam meus passos iniciais. Pessoas iluminadas que têm em mim o mais profundo e eterno agradecimento.

À Prof ${ }^{\mathrm{a}}$ Dr $^{\mathrm{a}}$ Rosana Baeninger, querida professora e amiga, por ter sido a primeira a acreditar na pesquisa, em mim e por ter me transmitido sua arte de pesquisar ao orientar o projeto dessa pesquisa. Muito obrigada por ter me emprestado um pouco da sua luz.

À Prof ${ }^{a}$ Dr $^{a}$ Maria Helena Augusto Oliva, que na hora certa não me deixou perder o ânimo frente às barreiras iniciais da transição entre uma universidade e outra.

Ao Prof. Dr. Mário Eufrásio, que com a maturidade e a clareza do seu fazer científico, aceitou e cumpriu o desafio de orientar uma pesquisa parcialmente fora do seu tema, oferecendo muito mais que orientação, mas também uma amizade companheira e sincera.

Fabíola Rodrigues, grande companheira de graduação e de sonhos, muito obrigada por ter sido a amiga de todas as horas e também ter tornado meu trabalho muito mais interessante do que eu poderia imaginar.

Alessandro Figueira e Daniel Sobreira, amigos de outro tempo, muito obrigada por também terem sido amigos de sempre.

À Gláucia Destro, companheira de estudos e de tema que partilha comigo a mesma paixão pela terra natal, agradeço as valiosas observações sobre aquilo que parece que acontece só com o outro, mas que acontecerá com todos nós: a velhice. Muito obrigada por ter divido comigo um pouco da sua sensibilidade.

Estabelecer-me em São Paulo foi uma aventura que influenciou sobremaneira meu olhar sobre Santos, que deixava de ser minha casa para se transformar no "outro" a ser observado e compreendido. Mas essa aventura não teria sido bem sucedida e não teria 
possibilitado a própria realização do trabalho se não fosse a acolhida da Tatiana Busto, do Danilo França, do Xicko (Francisco Veiga), da Juliana Ventura, da Lara Damha, do Diogo Oliva e do Eduardo Dias. Muito obrigada por toda a força!

Essa pesquisa nunca teria sido possível sem a colaboração gentil de todos os senhores e senhoras que entrevistamos. Muito obrigada pelas suas valiosas palavras, por pensarem junto comigo e compartilhar a história de suas vidas. Agradeço também a todos os estudiosos da cidade de Santos, sem os quais essa pesquisa não viria a existir.

Agradeço aos funcionários do Departamento de Sociologia, na pessoa da Ângela, à CAPES por ter subsidiado essa pesquisa por alguns meses e à Fundação Jorge Duprat Figueiredo de Medicina e Segurança do Trabalho - FUNDACENTRO por ter oferecido a oportunidade de uma dedicação parcial em horário de trabalho à confecção dessa pesquisa. Foi muito bom poder contar com um ambiente de pesquisa e com novos colegas. Agradeço especialmente à Dra Leda Leal Ferreira, chefe da Divisão de Ergonomia da Fundacentro onde trabalho, por me dar tranquiilidade, liberdade e acolhimento, proporcionando-me o melhor bem estar possível dentro das minhas condições de trabalho, possibilitando decisivamente o bom andamento dos trabalhos dessa dissertação.

E agradeço principalmente àqueles que sempre estiveram presentes, não por senso de dever, mas porque creram, amaram, e sustentaram como pilares a mim e aquilo que mal conheciam. Queridos pais, esse sonho realizado é obra de vocês. 


\section{SUMÁRIO}

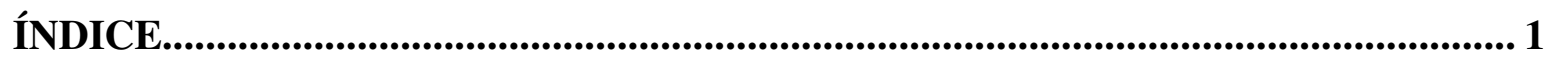

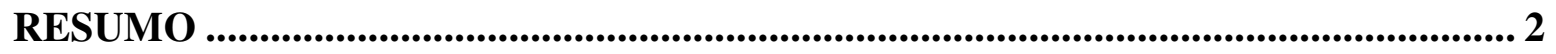

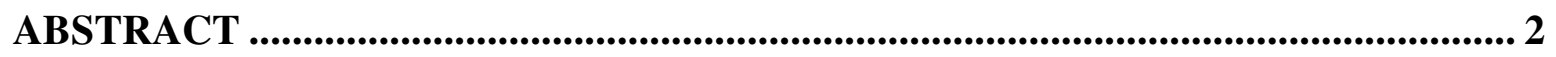

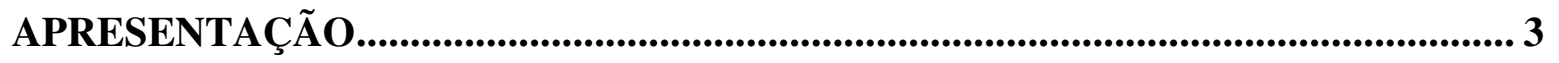

CAPÍTULO 1: O ENVELHECIMENTO POPULACIONAL DE SANTOS................... 6

CAPÍTULO 2: TEORIAS DA ESTRUTURA URBANA ............................................... 34

CAPÍTULO 3: A FORMAÇÃO DE SANTOS .......................................................... 64

CAPÍTULO 4: ENVELHECENDO NA CIDADE: A PRODUÇÃO DAS

LOCALIZAÇÕES URBANAS DE IDOSOS. .................................................................. 116

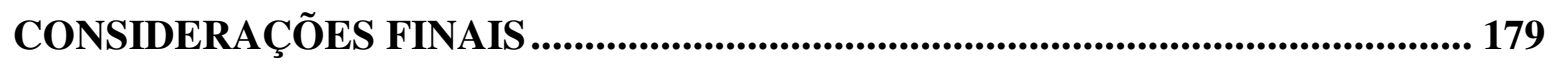

REFERÊNCIAS BIBLIOGRÁFICAS ................................................................ 182 


\section{ÍNDICE}

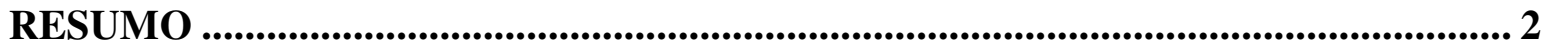

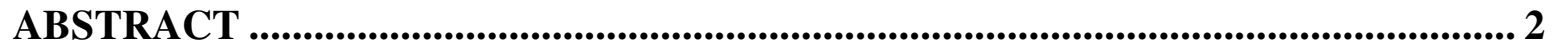

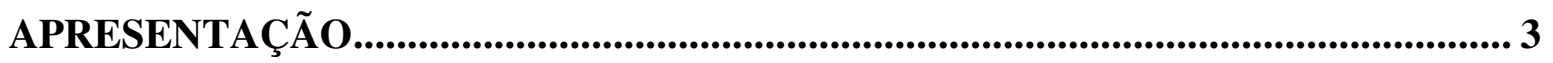

CAPÍTULO 1: O ENVELHECIMENTO POPULACIONAL DE SANTOS................... 6

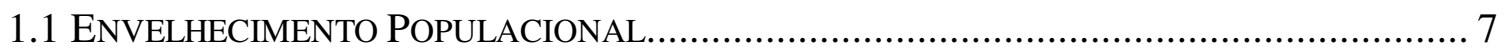

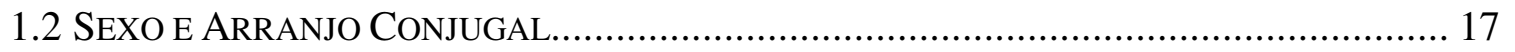

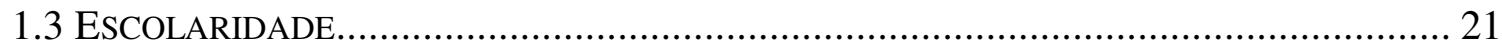

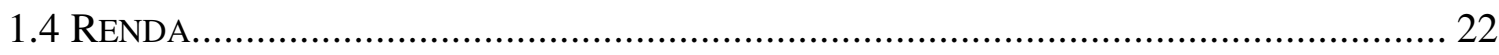

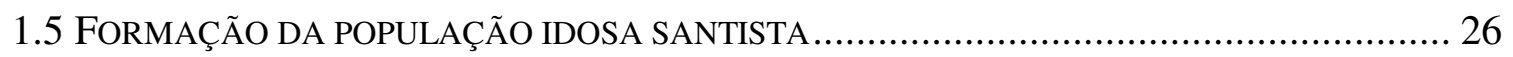

CAPÍTULO 2: TEORIAS DA ESTRUTURA URBANA ............................................. 34

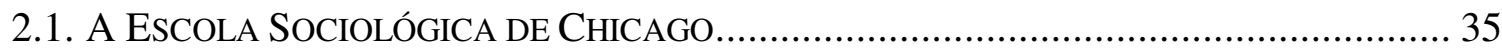

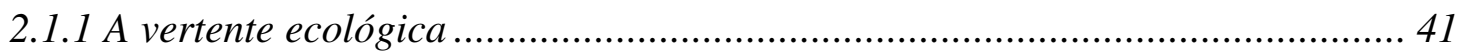

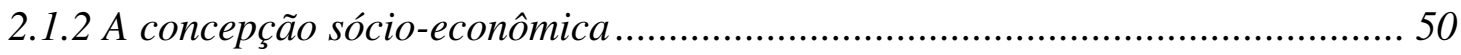

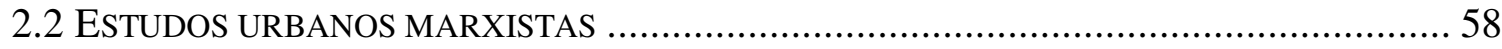

2.3 TEORIA DA LOCALIZAÇÃO INTRA-URBANA DE VILLAÇA. ............................................ 61

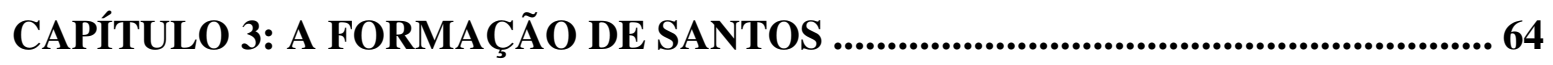

3.1 DO PERÍODO COLONIAL AOS PRIMEIROS “TEMPOS MODERNOS”................................. 64

3.2 "MAIS OUTRAS FUNÇÕES": O TERCEIRO MOMENTO DE ESTRUTURAÇÃO URBANA........ 87

CAPÍTULO 4: ENVELHECENDO NA CIDADE: A PRODUÇÃO DAS LOCALIZAÇÕES URBANAS DE IDOSOS. ................................................................. 116

4.1 A PRODUÇÃO DAS LOCALIZAÇÕES URBANAS ....................................................... 118

4.2. A SOCIABILIDADE E A APOSENTADORIA ......................................................... 128

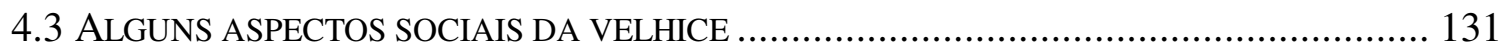

4.4 LoCALIZAÇÕES URBANAS DE IdOSOS DE SANTOS ................................................ 139

4.4.1 Procedimentos da pesquisa de campo:.......................................................... 139

4.4.2. No espaço público intra-urbano: praças, jardins e a rua............................... 141

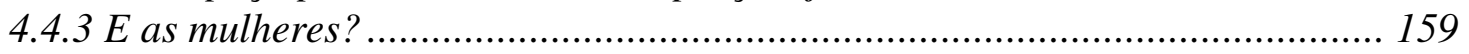

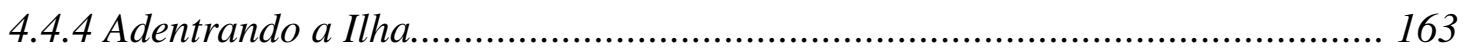

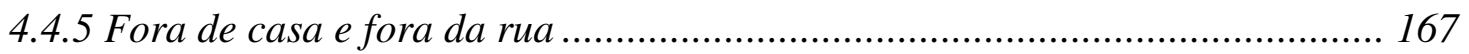

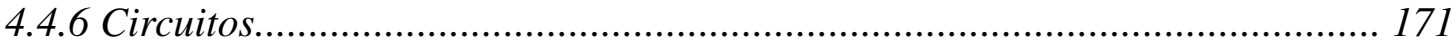

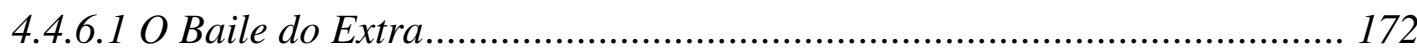

CONSIDERAÇÕES FINAIS ............................................................................................... 179

REFERÊNCIAS BIBLIOGRÁFICAS ................................................................ 182 


\title{
RESUMO
}

Este trabalho tentou compreender o envelhecimento populacional da cidade de Santos-SP e o cotidiano da sua população no espaço intra-urbano. Por meio do estudo da formação da estrutura urbana de Santos, de entrevistas semi-estruturadas e de uma reflexão sobre a sociabilidade na aposentadoria, sugerimos que a maioria da população idosa santista, que tem autonomia física e financeira, se faz mais presente em certos espaços da cidade do que em outros, conforme a lógica estrutural que organizou as áreas residenciais e as localizações urbanas na cidade. $\mathrm{O}$ estilo de vida engendrado durante os anos em que foram trabalhadores e o ideal cada vez mais socializado de um envelhecimento autônomo faz com que o segredo do bem envelhecer seja cada vez mais se abrir para o mundo de fora de casa. O uso de pontos do espaço intra-urbano por esses idosos como local de permanência e de sociabilidade - não só de rápida passagem - marcam-nos como "localizações urbanas de idosos", conferindo uma nova identidade à cidade, à velhice e aos próprios idosos.

Palavras chaves: estrutura urbana, espaço intra-urbano, envelhecimento, Santos, terceira idade.

\begin{abstract}
This work aims to comprehend the populational aging of the city of Santos, in São Paulo, Brazil, and the day-by-day of its aging population in the intra-urban space. By the study of the making of Santos's urban structure and through the analysis of interviews halfstructured, we suggest that the major part of the aged population of Santos with its physical and financial autonomy is more present in some spaces than in others, according to the logic of the urban structure that organized the residential areas and the urban locations in the city. The use of the certain places to stay instead of just a place to pass though marks them and the city itself. We call this marked places as "aging urban locations".
\end{abstract}

Keys words: urban structure, intra-urban space, aging, Santos, third age. 


\section{APRESENTAÇÃO}

O objetivo desta pesquisa é analisar as implicações urbanas do envelhecimento populacional em Santos-SP, cidade central da Região Metropolitana da Baixada Santista (RMBS), com grande participação na economia do Estado de São Paulo, abrigando o maior porto da América Latina. De acordo com o Censo Demográfico de 2000 do Instituto Brasileiro de Geografia e Estatística (IBGE), Santos tem 417.473 habitantes, e é altamente urbanizada $(99,46 \%$ da população vivendo em área urbana). Economicamente é uma cidade que vive predominantemente do setor de serviços voltado para sua própria população residente e metropolitana, para o porto e para o turismo. Das cidades da região é a que tem proporcionalmente menos população flutuante, a que mais perde nas trocas migratórias e a que se destaca continuamente desde a década de 1960 pelo seu grande número de idosos.

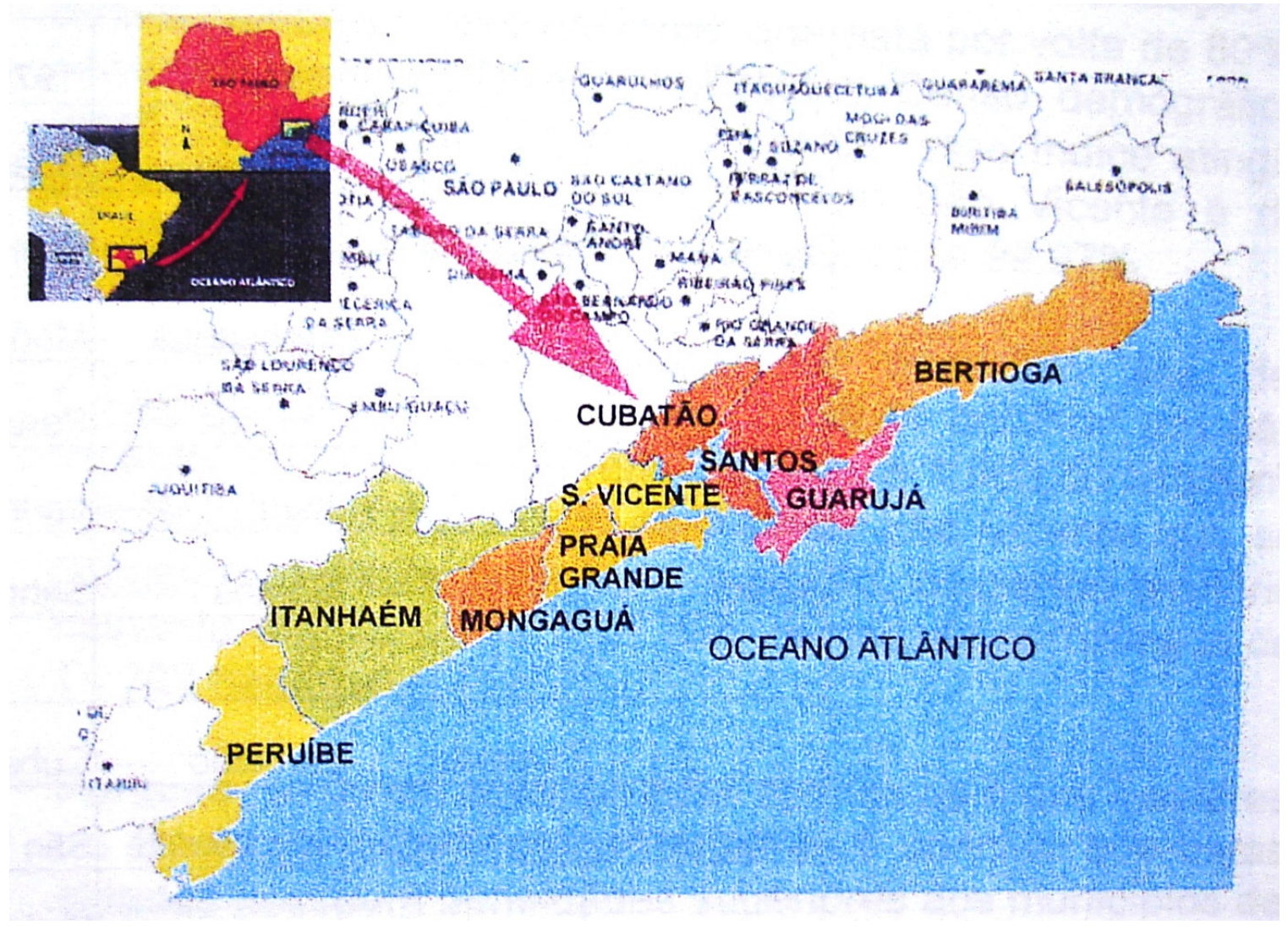

Figura 1: Localização da Região Metropolitana na Baixada Santista e dentro do Estado de São Paulo. Extraído de Carriço, (2002) p. 09. 
Em Santos, a proporção da população de 60 anos ou mais da cidade é de 15,7\%, quase o dobro da proporção dessa faixa etária na população total do país, que é de 8,56\%. Comparada com outras cidades da mesma classe de tamanho populacional (entre 200 mil e 500 mil habitantes), é a que tem a maior proporção de idosos no estado de São Paulo, se destacando também dentro da sua região metropolitana pelas características diferenciadas dessa população em termos de renda e grau de instrução. Quais os fatores que levaram Santos a exibir esse perfil populacional?

Junto com o envelhecimento populacional que acontece no país como um todo, vem à tona também uma redefinição da velhice: como considerar idosa uma pessoa que pode ter quarenta anos ainda por viver? E como vive essa atual geração de jovens idosos? Como veremos, Santos tem os elementos para "reinvenção" da velhice da qual falou Debert (1999) e novamente se destaca por isso.

A nosso ver, pode ser frutífero buscar uma análise crítica dos processos que levaram Santos a estar numa fase do envelhecimento populacional que outras cidades do país poderão, em breve, vivenciar. Entretanto a vontade de conhecer a fundo suas origens e tendências futuras e o fato de esta pesquisadora ser natural de Santos e estar próxima dos personagens desse novo envelhecimento também motivaram essa pesquisa.

Entre as variadas maneiras de constituir esse fenômeno num objeto de estudo, optamos pela de relacionar o espaço intra-urbano de Santos com os usos que a população idosa faz dele. Para isso, foi necessário estudar o aumento do número de pessoas idosas como um fenômeno demográfico e entendê-lo dentro da história da formação da cidade que conhecemos hoje, o que nos exigiu conhecer duas grandes discussões das ciências sociais: a construção sociológica do tema da cidade e a construção social do envelhecimento.

O primeiro capítulo tenta cumprir o primeiro passo: caracterizar o envelhecimento populacional de Santos. No segundo capítulo procuramos compreender como a sociologia urbana pode ajudar nessa tarefa, e vemos no conceito de estrutura urbana uma chave de compreensão dos processos que formam e organizam a cidade. O terceiro capítulo tem a função de examinar a história da formação da cidade à luz desse olhar sociológico e situar o envelhecimento populacional como processo constitutivo da Santos atual. 
Postas as origens da cidade e do envelhecimento da sua população, o objetivo do quarto capítulo foi compreender como a população idosa usa os espaços da cidade. Novamente foi necessário recorrer a ferramentas teóricas que pudessem evidenciar exageradamente - tal como uma lupa aumenta um pequeno ponto que se quer observar em detalhe - como certos espaços da cidade escolhidos sob uma determinada lógica urbana e social e sob determinadas concepções sociais da velhice ou da vida pós-trabalho - são marcados pela presença de pessoas com mais de 60 anos. O conceito de localização urbana nos ajuda a ressaltar a centralidade e a especificidade social desses espaços, que só puderam ser reconhecidos por meio de uma pesquisa de campo.

Entre os nossos procedimentos de pesquisa esteve a habitual e necessária revisão bibliográfica e também entrevistas semi-estruturadas feitas em três fases: a primeira, exploratória; a segunda, de identificação das localizações urbanas e de teste das hipóteses iniciais do projeto de pesquisa; e a terceira de conhecer a história da vida de três senhoras e dois senhores com mais de 60 anos, confirmando algumas hipóteses que surgiram no decorrer da pesquisa e apontando outras perspectivas. Em todos os momentos deste texto em que há falas dos entrevistados optamos por utilizar pseudônimos para preservar a identidade das pessoas e mostrá-las como personagens, ao invés do uso das siglas, a nosso ver, tão impessoais. A análise da pesquisa de campo está posta em sua maior parte no capítulo quatro, mas ela deu bases também para as hipóteses sobre a estruturação urbana de Santos expostas do capítulo três.

No final do trabalho há algumas considerações finais que sumarizam as conclusões de toda a pesquisa e ainda muitas questões. Afinal, há um longo caminho pela frente na tarefa de estudar uma população e uma cidade que ainda têm muito a amadurecer. 


\section{Capítulo 1: O Envelhecimento Populacional de Santos}

Quando iniciamos, em 2003, o projeto de pesquisa que resulta agora nesta dissertação, o envelhecimento populacional já era um tema debatido nas ciências sociais brasileiras, mas hoje, em 2006, a construção do tema já chega a ser revisada, como mostrou a atualização do estudo do IPEA sobre os idosos brasileiros (Camarano et al, 2004). Conceitos e novas categorias foram sendo criados para dar conta das particularidades de um tema que vem se demonstrando cada vez mais complexo. A análise dos dados da população idosa começa a ser feita separadamente em duas grandes faixas etárias (de 60 a 79 anos e de 80 anos ou mais), e comparativamente entre as variáveis mais importantes para caracterizar as condições de vida dessa população (sexo, raça/etnia, grau de instrução, esperança de vida, mortalidade, e o recente conceito de "autonomia física"). Há, ainda, autores que estudam temas peculiares ou mais relevantes para os idosos, como a aposentadoria e o fim do período de trabalhar, o acesso aos serviços de saúde, as universidades da terceira idade, e a própria situação e imagem social do idoso (Debert, 1999; Peixoto, 2000; Pacheco 2004; Py, 2004; entre outros.). E além das ciências sociais, as ciências biológicas e outras ciências humanas também têm aumentado sua atenção para o tema, que ficou definitivamente consagrado nas políticas públicas depois da ratificação do Estatuto do Idoso em 2003. Diante desses avanços precisamos revisar o cenário de nosso objeto de estudo, que fornece a oportunidade de observar numa cidade a intensificação de um fenômeno sociodemográfico nacional.

Neste primeiro capítulo, o objetivo é caracterizar o envelhecimento populacional de Santos observando-se comparativamente o estado, o país e a região metropolitana nas suas características sócio-demográficas, com foco nas variáveis fundamentais condicionantes da participação do idoso na dinâmica da estrutura urbana ${ }^{1}$ : autonomia física (a capacidade do idoso de realizar as atividades cotidianas sem ajuda de terceiros), renda, grau de instrução, sexo e estado conjugal.

\footnotetext{
${ }^{1}$ A escolha das variáveis se deu após o exame da bibliografia brasileira sobre o envelhecimento populacional que observou quais os fatores condicionantes da experiência de envelhecer (Veras, 1995; Debert, 1999; Berquó, 1996; Camarano, 2004; Freitas, 2004 para citar alguns) e também pela disponibilidade dos dados demográficos e de pesquisa de campo.
} 
Como o segmento idoso que mais cresce no Brasil é o de 80 anos ou mais - em ritmo maior até que o da população idosa total - o intervalo correspondente à classificação “idoso" é cada vez mais longo - uma pessoa de “60 anos ou mais” pode ter até mais de 90 anos, e em Santos, como veremos, essa situação é recorrente. Para uma análise mais objetiva da população idosa torna-se necessário desagregá-la em dois grupos etários: de 60 a 79 anos e de 80 anos ou mais. Essa divisão, sugerida por Camarano et al (2004), será utilizada em todo o capítulo, sempre que os dados do Censo Demográfico e da PNAD (Pesquisa Nacional por Amostra de Domicílios) possibilitarem esse procedimento.

\subsection{Envelhecimento Populacional}

O envelhecimento populacional define-se pelo aumento da participação das faixas etárias mais avançadas na estrutura etária da população. Pode ser resultante da emigração da população jovem em idade reprodutiva, ou da queda das taxas de mortalidade, natalidade e fecundidade. Telles (2003), que estudou a constituição dos arranjos familiares dos idosos, salienta que de acordo com a faixa etária sobre a qual a queda de mortalidade se incide, temse uma estrutura etária diferenciada, com outra configuração de envelhecimento. Se a mortalidade cai entre os mais jovens, a população ficará "rejuvenescida", pois aumenta proporcionalmente os grupos em idade pré-reprodutiva, e, dependendo do nível de fecundidade (se não estiver baixo), há uma renovação da população. Se a mortalidade cai entre os mais velhos, intensifica o aumento da população idosa. Essa é a situação mais recorrente nos países desenvolvidos, nos quais essa queda é resultante de melhoria das condições sociais, da boa saúde da população, resultando num aumento da longevidade.

Quando a taxa de mortalidade está estável e a taxa de fecundidade caindo há "uma redução relativa da participação da população jovem e aumento da participação da população velha" (Telles, 2003). É o que se chama de envelhecimento populacional "pela base”. Mas se aumenta o número de velhos e não há redução no número de jovens, ocorre o envelhecimento populacional "pelo topo". No Brasil, ocorre redução tanto na taxa da mortalidade quanto na de fecundidade.

Esse padrão de comportamento demográfico de poucos filhos por mulher e aumento da longevidade começa a se configurar nos anos 1970, segundo a mesma autora. Mas o 
envelhecimento populacional está dentro da evolução demográfica da população brasileira desde a década de 1940, quando declinava a imigração internacional que fazia com que a população sempre tivesse muitos adultos jovens (Berquó, 1999). Começa, então, a crescer a proporção de idosos e se inicia a "Transição Demográfica" (Ramos, 2002 apud Freitas, 2004), que consiste na mudança do padrão de distribuição etária por meio da variação da taxa da mortalidade e da fecundidade, influenciadas pelos avanços científicos na prevenção de doenças e no aumento da longevidade; pela consolidação da urbanização; pela queda da imigração; por fatores culturais de redução do tamanho da família entre outros ${ }^{2}$.

A Transição Demográfica é um fenômeno marcado por quatro estágios. O primeiro é caracterizado por alta fecundidade e alta mortalidade, resultando numa população predominantemente jovem. No segundo estágio, a fecundidade continua alta, mas com os avanços científicos e sociais na prevenção de doenças, começa a cair a taxa de mortalidade. No terceiro estágio, a taxa de fecundidade entra em queda junto com mortalidade e começa a haver maior proporção de adultos e jovens, não mais de crianças. No último estágio, com a continuidade da redução da taxa de fecundidade e de mortalidade, torna-se expressivo o número de idosos. Segundo Freitas (2004), a população brasileira está no terceiro estágio dessa transição. De fato, a pirâmide etária brasileira de 2000 (gráfico1) mostra uma predominância de jovens adultos e uma proporção maior de idosos que a dos censos anteriores.

\footnotetext{
${ }^{2}$ Não há um consenso sobre os fatores exatos que causam a Transição Demográfica, sendo este um fenômeno vastamente estudado pela Demografia. Nos limites deste texto, seguimos as premissas de Freitas (2004).
} 


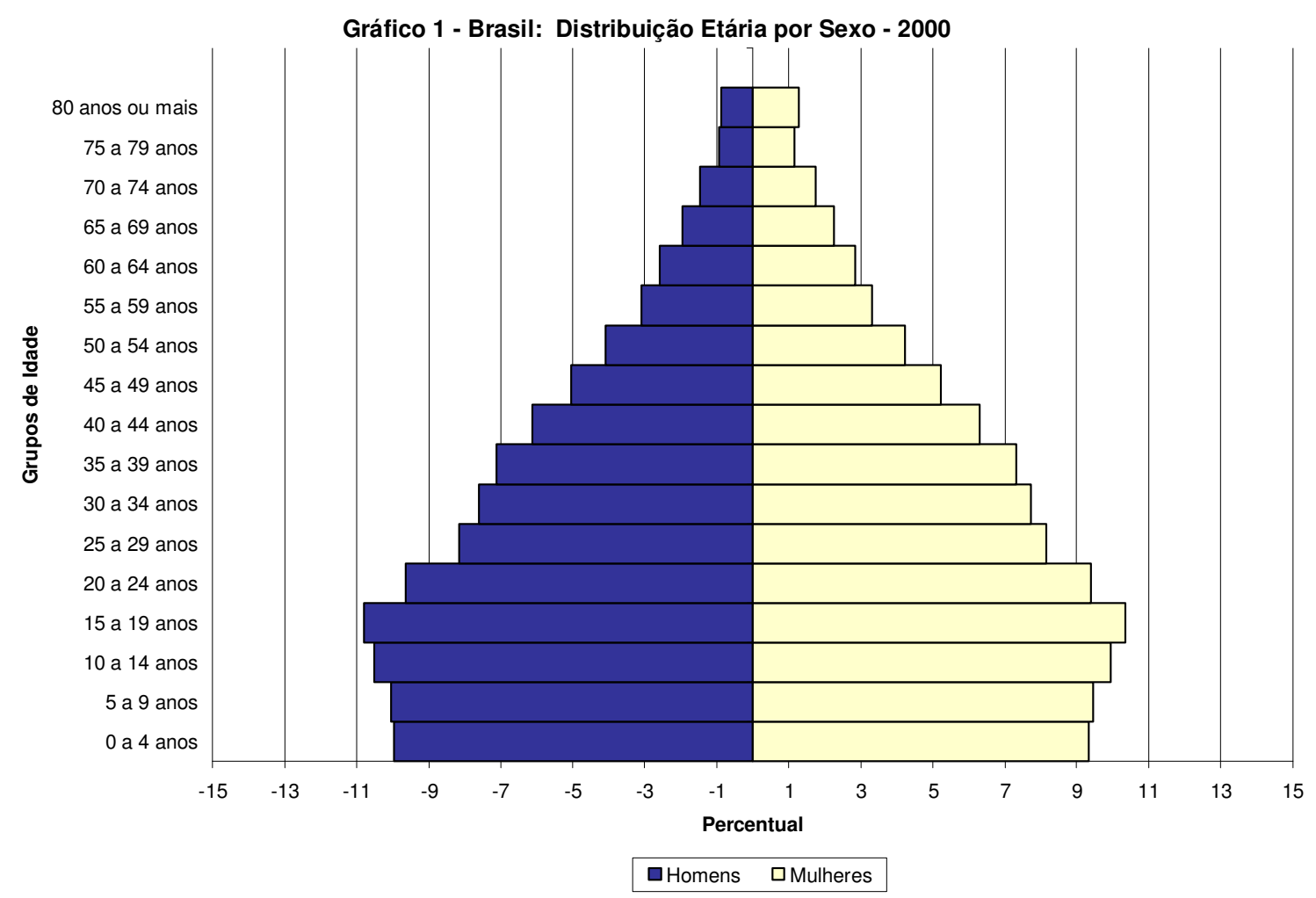

Fonte: IBGE/Censo Demográfico 2000.

Gráfico 2 - Brasil: Distribuição etária por sexo - Ano 1991

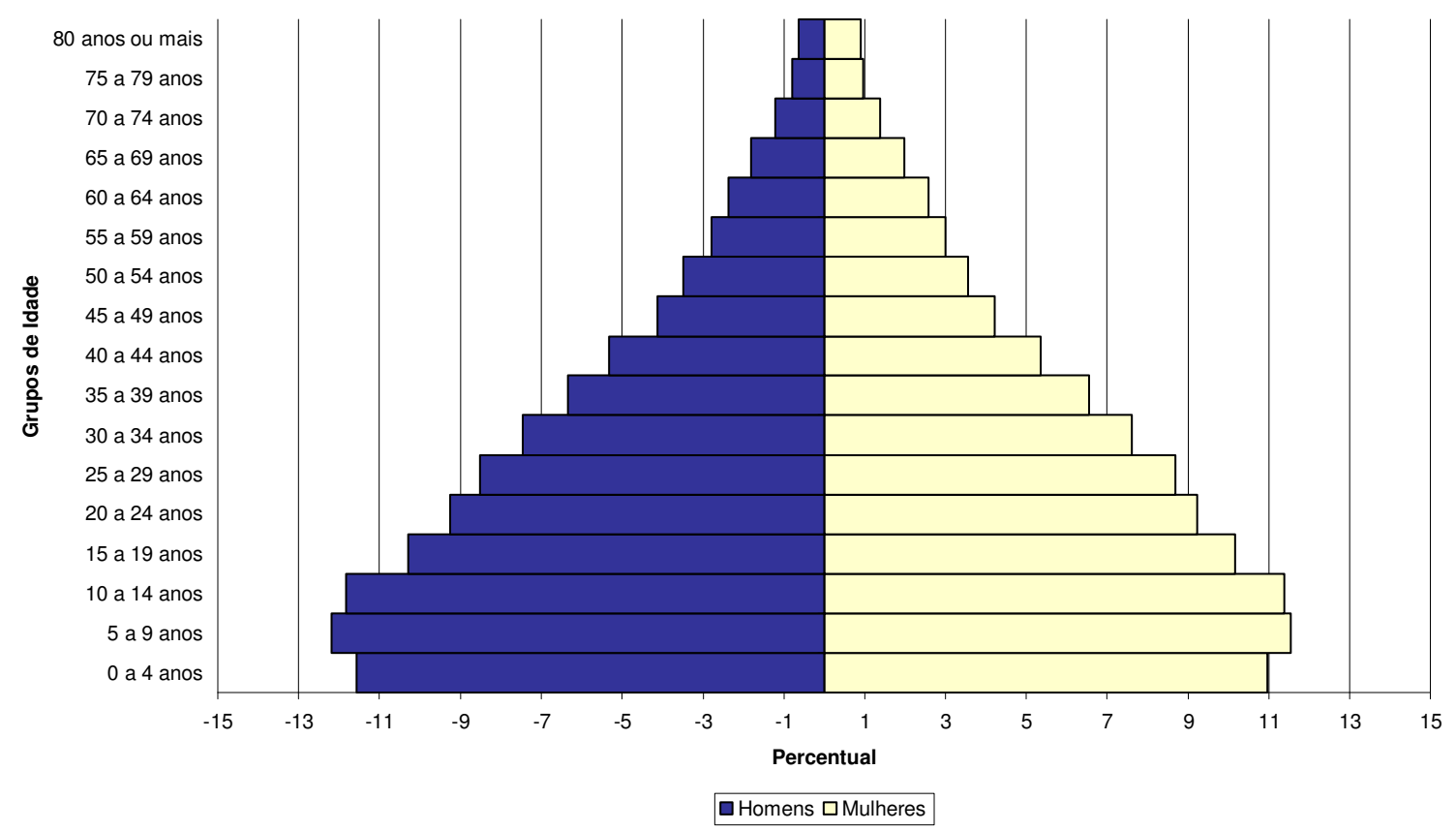

Fonte: IBGE: Censo Demográfico 1991 


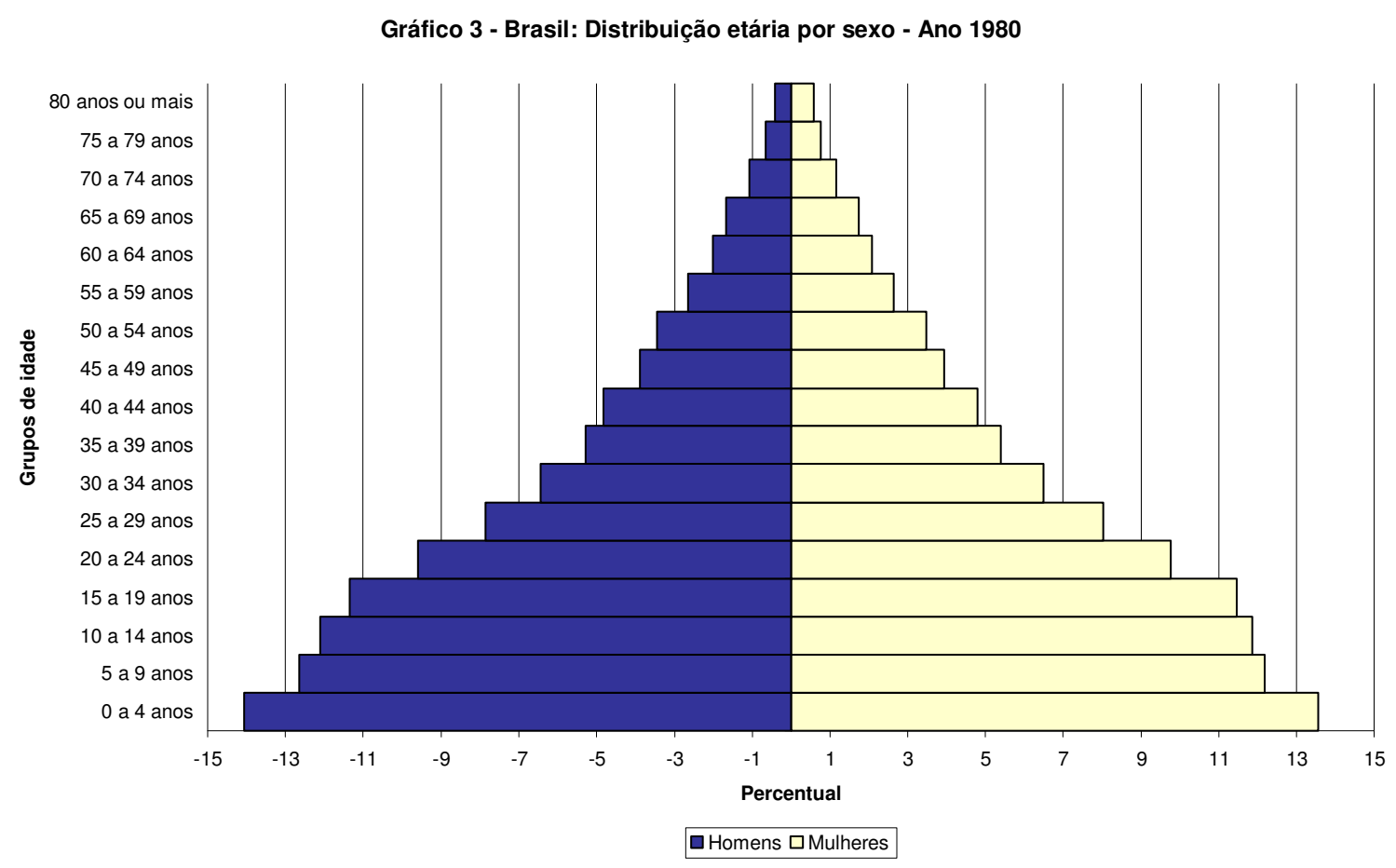

Fonte: IBGE: Censo Demográfico 1980

Camarano et al (2004) assinala que o aumento da população idosa no Brasil deve-se principalmente à alta fecundidade entre os anos 1950 e 1960 e à redução da taxa de mortalidade da própria população idosa, o que resulta também no aumento da expectativa de vida. Por outro lado, a taxa de fecundidade cai sistematicamente a partir da década de 70, o que faz com que a proporção de pessoas idosas pareça maior nas décadas posteriores, já que a reposição de jovens foi diminuindo. O Censo 2000 mostra que a faixa etária que mais cresceu foi a de 80 anos e mais.

A Transição Demográfica é também resultado da transição epidemiológica que acontece desde o começo do século XX. Se antes eram causas comuns de morte as doenças infecto-contagiosas com alta incidência em crianças com menos de um ano (mortalidade infantil) e na população em geral, hoje, esses eventos são reduzidos, resultando num declínio expressivo da mortalidade geral. Entre 1980 e 2000 a maior redução da mortalidade na população foi na faixa dos 70 a 79 anos e a esperança de vida passou de 58,5 anos para 68,5 
anos entre 1980 e 2003 (IBGE 2003 in Freitas, 2004). Na população feminina, a esperança de vida era de 76 anos em 2000 e essa diferença está aumentando. E mesmo a idade média ao morrer, que não acompanha necessariamente a evolução da esperança de vida ao nascer, aumenta no Brasil.

Com a queda na taxa de fecundidade que vem ocorrendo desde os anos 1970, a população em idade reprodutiva e a população em idade ativa sofre uma redução, o que pode causar um desequilíbrio nas contas relacionadas à previdência social, sobretudo com a crescente informalidade da economia. Camarano et al (2004) alerta que o envelhecimento populacional no Brasil vem acompanhado de um envelhecimento da PEA (população economicamente ativa). Nesse mesmo contexto, o ritmo de crescimento absoluto da população brasileira vem diminuindo desde 1960 e desde 1940 o segmento que mais cresce é o idoso, ou seja, o envelhecimento populacional é uma tendência consolidada. No entanto, outra tendência crescente é a chamada "onda jovem", fenômeno demográfico caracterizado pelo predomínio na estrutura etária da faixa dos 15 a 24 anos devido às descontinuidades demográficas geradas pelas mudanças nos padrões de fecundidade e mortalidade das décadas imediatamente anteriores, sobretudo na queda da mortalidade infantil (Bercovich e Massé, 2004). A pressão no mercado de trabalho cresce, pois os muitos adolescentes e crianças que compunham a base larga da pirâmide etária dos anos 1970 e 1980 estão agora buscando seus primeiros empregos, concorrendo com idosos que, mesmo depois de aposentar-se, ainda não puderam sair do mercado de trabalho.

Telles (2003) ressalta que no Brasil há mais gastos públicos com previdência do que com educação, o que faz com que o envelhecimento populacional seja visto inicialmente como um problema econômico-social. Os gastos públicos com a população idosa são ainda maiores quando lembramos que futuramente a tendência é que cresça ao Estado a demanda por cuidados de idosos, pois a população idosa cresce mais entre seus mais velhos (aumento da longevidade) e a tendência da organização das famílias é a de participação cada vez menor das mulheres, que são na grande maioria dos casos, as que cuidam dos idosos em casa:

"A maior parte da responsabilidade com o cuidado ao idoso é atribuída à família, e mais precisamente, à mulher, que ocupa predominantemente os papéis de 
mãe e esposa no curso da vida familiar. Apesar de muito se falar na família no cuidado e apoio aos jovens e aos idosos, na prática, é que as responsabilidades diárias dependem do tempo e da disponibilidade de tempo das mulheres". (Telles, 2003, p.23)

Essa informação pode ser corroborada por nosso universo de entrevistados. Somente mulheres apareceram como "cuidadoras" de idosos (a maioria era esposas cuidando de seus maridos ou, mais raramente, de seus pais), e mesmo as que precisavam de cuidados, eram auxiliadas por mulheres, geralmente parentes.

Com as mulheres cada vez mais presentes no mercado de trabalho e o aumento no número de divórcios, a organização familiar sofre uma redefinição e precisará de mais assistência do Estado. Além disso, o envelhecimento populacional dos países emergentes ocorre menos por melhoras na qualidade de vida e mais por avanços tecnológicos na medicina (Freitas 2004). É também, e talvez principalmente, fruto de um prolongamento de uma vida sofrida e carente de cuidados.

No entanto, as conclusões de Camarano et al (2004) em estudo de revisão sobre as condições de vida do idoso brasileiro apontam para uma relação de dependência mais favorável aos idosos:

"A relação entre envelhecimento e dependência não é tão clara. Uma parcela expressiva de indivíduos que, apesar de serem considerados idosos, ainda está em pelo vigor físico, gozando de boa saúde e está inserida no mercado de trabalho, mesmo aposentada, assumindo papéis não esperados, como o de suporte a outros membros da família, especialmente a filhos adultos" (Camarano et al, 2004, p.71).

Essa situação foi presente em nossas entrevistas nas famílias pobres, residentes em bairros mais interiores de Santos (os bairros mais pobres). Segundo nosso universo de entrevistados que eram chefes de domicílio, quanto menor a renda, mais pessoas no domicílio.

Por outro lado, as mesmas autoras afirmam que "uma parcela não desprezível da população idosa tem dificuldades em ouvir, enxergar, subir escadas e lidar com as atividades básicas do cotidiano. (...) É esse o segmento que demanda cuidados, o que, no caso brasileiro, recai em quase toda a sua totalidade sobre a família" (Camarano et al, 2004, p.71). 
Se o envelhecimento populacional já é flagrante e consolidado no Brasil, em Santos é ainda mais intenso e particular, pois se difere não só das estatísticas nacionais, mas também do envelhecimento populacional que se observa na sua própria região metropolitana, como mostra a comparação entre as distribuições etárias do Brasil, do Estado de São Paulo, da Região Metropolitana de Santos (RMBS) e de Santos:

Gráfico 4- São Paulo: Distribuição Etária por Sexo - Ano 2000

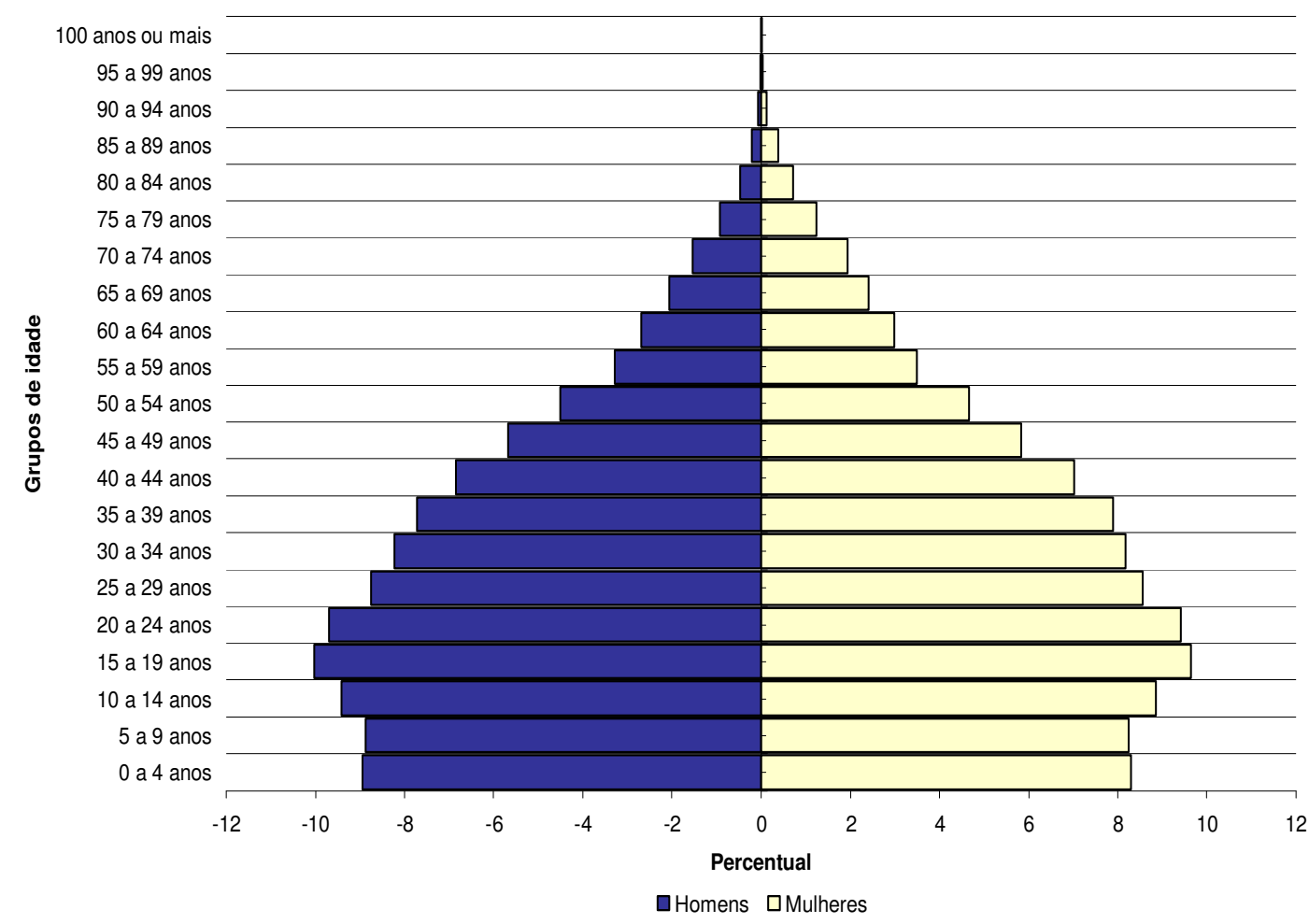


Gráfico 5 - Região Metropolitana da Baixada Santista: Distribuição Etária por Sexo - Ano 2000
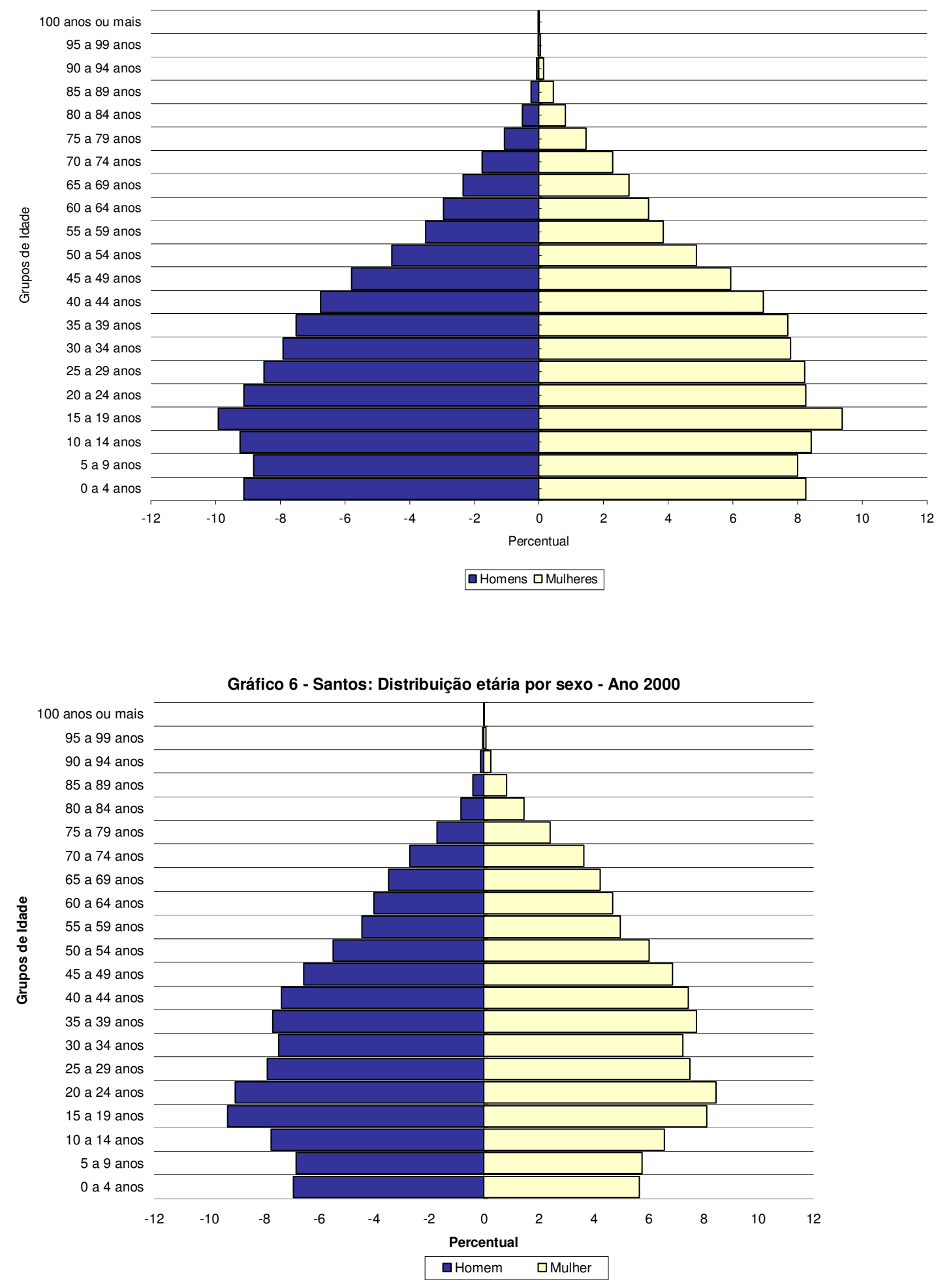

Fonte: IBGE, Censo Demográfico 2000. 
As distribuições etárias do estado de São Paulo e da região parecem seguir o mesmo padrão, apresentando a "onda jovem”. Porém, esse predomínio de jovens (entre 15 e 24 anos) é mais acentuado em Santos, assim como é mais acentuado o aumento do número de idosos e a diminuição da fecundidade e da natalidade, observável pela base estreita da pirâmide. Mas em Santos, há ainda diferenças dentro da distribuição da própria população idosa, como mostram o gráfico e a tabela a seguir:

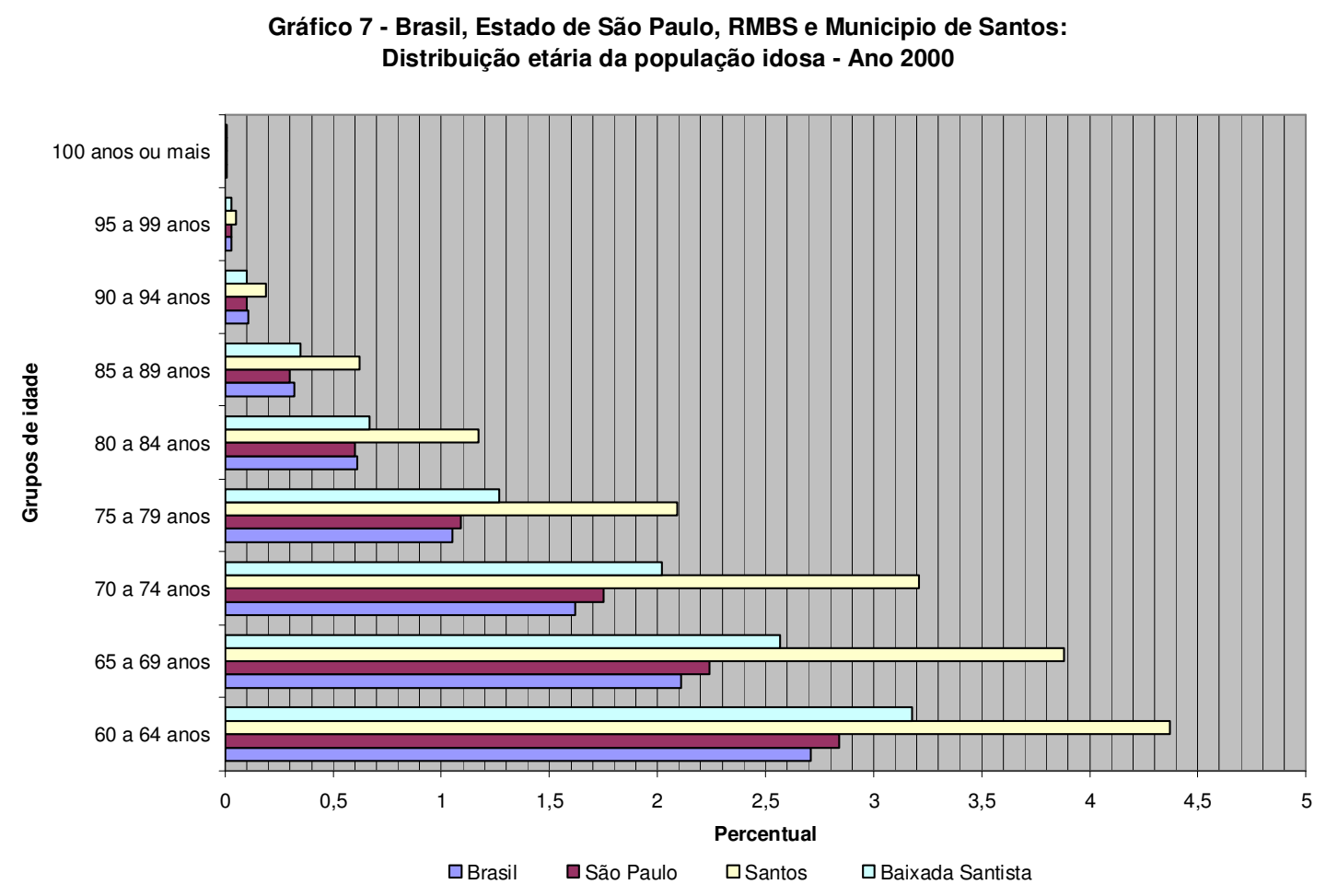

Fonte: IBGE, Censo Demográfico 2000. 


\begin{tabular}{|c|c|c|c|c|}
\hline \multicolumn{5}{|c|}{ Tabela 1- População residente por grupos de idade (percentual) } \\
\hline Grupos de idade & Brasil & São Paulo & Santos - SP & RMBS \\
\hline 0 a 4 anos & 9,64 & 8,62 & 6,25 & 8,68 \\
\hline 5 a 9 anos & 9,74 & 8,55 & 6,26 & 8,39 \\
\hline 10 a 14 anos & 10,22 & 9,14 & 7,11 & 8,82 \\
\hline 15 a 19 anos & 10,57 & 9,83 & 8,68 & 9,64 \\
\hline 20 a 24 anos & 9,51 & 9,55 & 8,73 & 9,34 \\
\hline 25 a 29 anos & 8,16 & 8,66 & 7,67 & 8,36 \\
\hline 30 a 34 anos & 7,67 & 8,21 & 7,35 & 7,84 \\
\hline 35 a 39 anos & 7,22 & 7,81 & 7,71 & 7,6 \\
\hline 40 a 44 anos & 6,21 & 6,93 & 7,41 & 6,86 \\
\hline 45 a 49 anos & 5,14 & 5,76 & 6,72 & 5,87 \\
\hline 50 a 54 anos & 4,16 & 4,59 & 5,77 & 4,71 \\
\hline 55 a 59 anos & 3,21 & 3,4 & 4,73 & 3,68 \\
\hline 60 a 64 anos & 2,71 & 2,84 & 4,37 & 3,18 \\
\hline 65 a 69 anos & 2,11 & 2,24 & 3,88 & 2,57 \\
\hline 70 a 74 anos & 1,62 & 1,75 & 3,21 & 2,02 \\
\hline 75 a 79 anos & 1,05 & 1,09 & 2,09 & 1,27 \\
\hline 80 a 84 anos & 0,61 & 0,6 & 1,17 & 0,67 \\
\hline 85 a 89 anos & 0,32 & 0,3 & 0,62 & 0,35 \\
\hline 90 a 94 anos & 0,11 & 0,1 & 0,19 & 0,1 \\
\hline 95 a 99 anos & 0,03 & 0,03 & 0,05 & 0,03 \\
\hline 100 anos ou mais & 0,01 & 0,01 & 0,01 & 0,01 \\
\hline
\end{tabular}

Os dados acima mostram como o número de idosos em Santos é proporcionalmente maior, mas mostram também um envelhecimento mais jovem que o de São Paulo e o do Brasil, com maior proporção de "jovens idosos" (entre 60 a 69 anos) em Santos. Isto significa que, a não ser que haja forte alteração no padrão de mortalidade ou de migração, a população idosa em Santos tende a persistir e a aumentar entre seus mais velhos: a base está posta. A distribuição da Região Metropolitana da Baixada Santista parece seguir a mesma tendência de Santos, mas é preciso considerar que os dados do município de Santos, presentes também nessa distribuição, podem estar causando essa aproximação.

Um dos fatores determinantes da independência do idoso e, conseqüentemente, da sua participação na organização diária da estrutura urbana, ou seja, na produção das localizações urbanas é a autonomia física ou funcional. Sem ela, mesmo que o idoso tenha alto grau de instrução ou renda, terá menos chance de vivenciar a cidade e consumir seu 
espaço. Esse fator é condicionado preponderantemente pelo aumento da idade. Como já observamos, em Santos há concentração de população idosa nas primeiras faixas do intervalo etário, o que resulta - ao menos com relação ao quesito idade - numa população mais independente e autônoma. Mas a autonomia ou a independência do idoso é fruto de uma relação entre suas condições físicas, renda, arranjo domiciliar e familiar, sua localização espacial, (Camarano et al 2004) entre outras variáveis que foram observadas nas entrevistas analisadas no quarto capítulo. Numa perspectiva populacional, a variável que mais diferencia as condições de vida entre os idosos é a de sexo ${ }^{3}$.

\subsection{Sexo e Arranjo Conjugal}

A análise da estrutura etária da população idosa revela uma característica importante do envelhecimento populacional brasileiro: a feminização da velhice. Já em 1999, Berquó chamava atenção para este fenômeno e para a diferença entre as condições de vida das idosas e dos idosos. Uma população idosa com maioria feminina significa uma velhice mais solitária, dependente, mas cada vez mais ativa, com mais espaço para a reinvenção da velhice a qual discutiu Debert (1999) e que tentamos identificar em Santos no quarto capítulo.

No Brasil $55 \%$ da população idosa é de mulheres ${ }^{4}$, e quanto mais idoso o segmento, mais feminino é, principalmente nas áreas urbanas (nas áreas rurais predominam os homens, que participaram menos nos fluxos migratórios para a cidade). A taxa de mortalidade da população idosa é menor entre as mulheres, mas se vivem mais, são as mulheres também as que mais sofrem com a debilidade física até a morte.

A velhice feminina é socialmente bastante diferente da masculina, a começar por uma das condições que mais influenciam o bem-estar do idoso, segundo os dados verificados por Telles (2003): o estado conjugal. Há mais homens idosos casados do que idosas, embora o

\footnotetext{
${ }^{3}$ Não só sexo e nem gênero, mas ambos são decisivos no envelhecimento do(a) brasileiro(a), pois se as mulheres são mais longevas, é em grande parte porque estiveram longe das condições dos trabalhos pesados, reservados aos homens. Por outro lado, sofrem as consequiências da ausência da aposentadoria devido aos constrangimentos sociais antigos que as impediam de trabalhar.

${ }^{4}$ As informações analíticas desse capítulo foram elaboradas por um conjunto de estudos que utilizamos aqui conforme nossa construção do tema do envelhecimento populacional. Não são dados elaborados por nós, portanto.
} 
número de idosas casadas esteja aumentando, junto com o número de viúvos na última década. Ainda assim, é grande a diferença entre os sexos. No Brasil há 40,8\% das mulheres idosas viúvas, o mesmo número de mulheres casadas, para 77,3\% de homens casados.

Ainda de acordo com Telles (2003), que utilizou como fonte de dados a PNAD de 1999, as idosas brasileiras estão na sua maioria morando com parentes (filhos, genros ou noras) $(21,3 \%)$, em famílias monoparentais ${ }^{5}$ (20\%), em terceiro lugar, casadas sem filhos (18,4\%), 15,9\% morando sozinhas e 12,6 \% chefiando domicílios com cônjuge e filhos.

A população idosa feminina, de maneira geral, é a que menos usufrui a aposentadoria, vivendo da pensão dos maridos, e/ou da ajuda dos filhos. "Experimentam menor autonomia e maior percentual de pessoas que não tem rendimento e, provavelmente por isso, moram em casa de 'outros parentes"' (Camarano et al 2004, p.54). Mas a tendência é a do aumento futuro do número de aposentadas, devido à maior presença no mercado de trabalho atualmente (Wajman, 2004).

No Brasil apenas $12 \%$ dos homens idosos estão viúvos e 6,2\% estão divorciados, sendo que o número de viúvos vem decrescendo com o recasamento. Já o número de viúvas vem aumentando e já é 3,4 vezes maior que o de viúvos. Aumenta também o número de divorciados, mas mais entre as mulheres: 6,2\% de homens idosos divorciados para 11,8\% de mulheres idosas divorciadas.

Em Santos há mais mulheres idosas do que homens, como mostrou o gráfico 6. Nos gráficos 8 e 9 vemos que a maioria dessas mulheres é viúva.

\footnotetext{
${ }^{5}$ Famílias sem cônjuge, mas com algum parente.
} 
Gráfico 6 - Santos: Estado Conjugal da populacão de 60 a 79 anos por sexo - Ano 2000

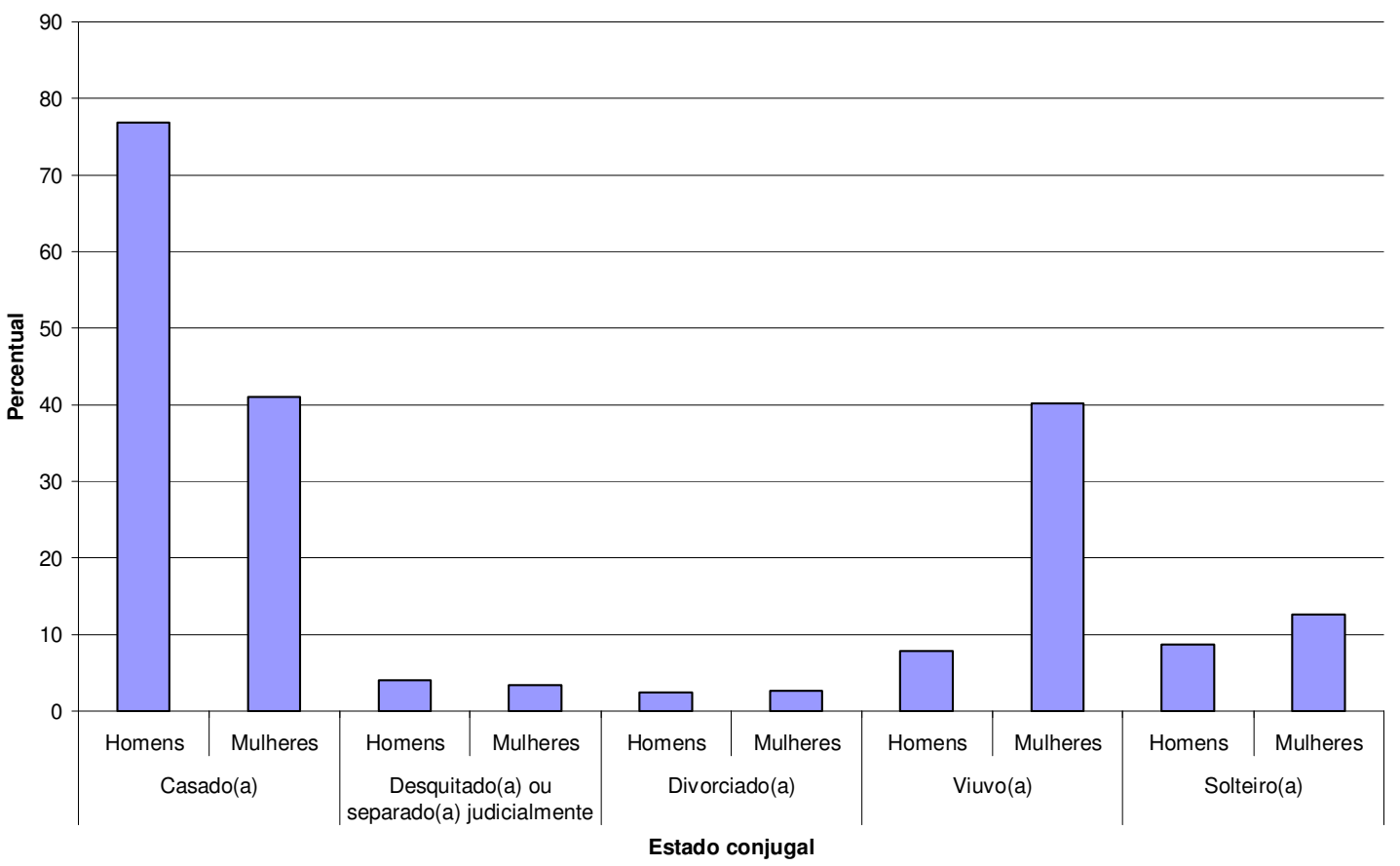

Fonte: IBGE, Censo Demográfico 2000. 
Gráfico 9 - Santos: Estado conjugal da população de 80 anos ou mais por sexo - Ano 2000

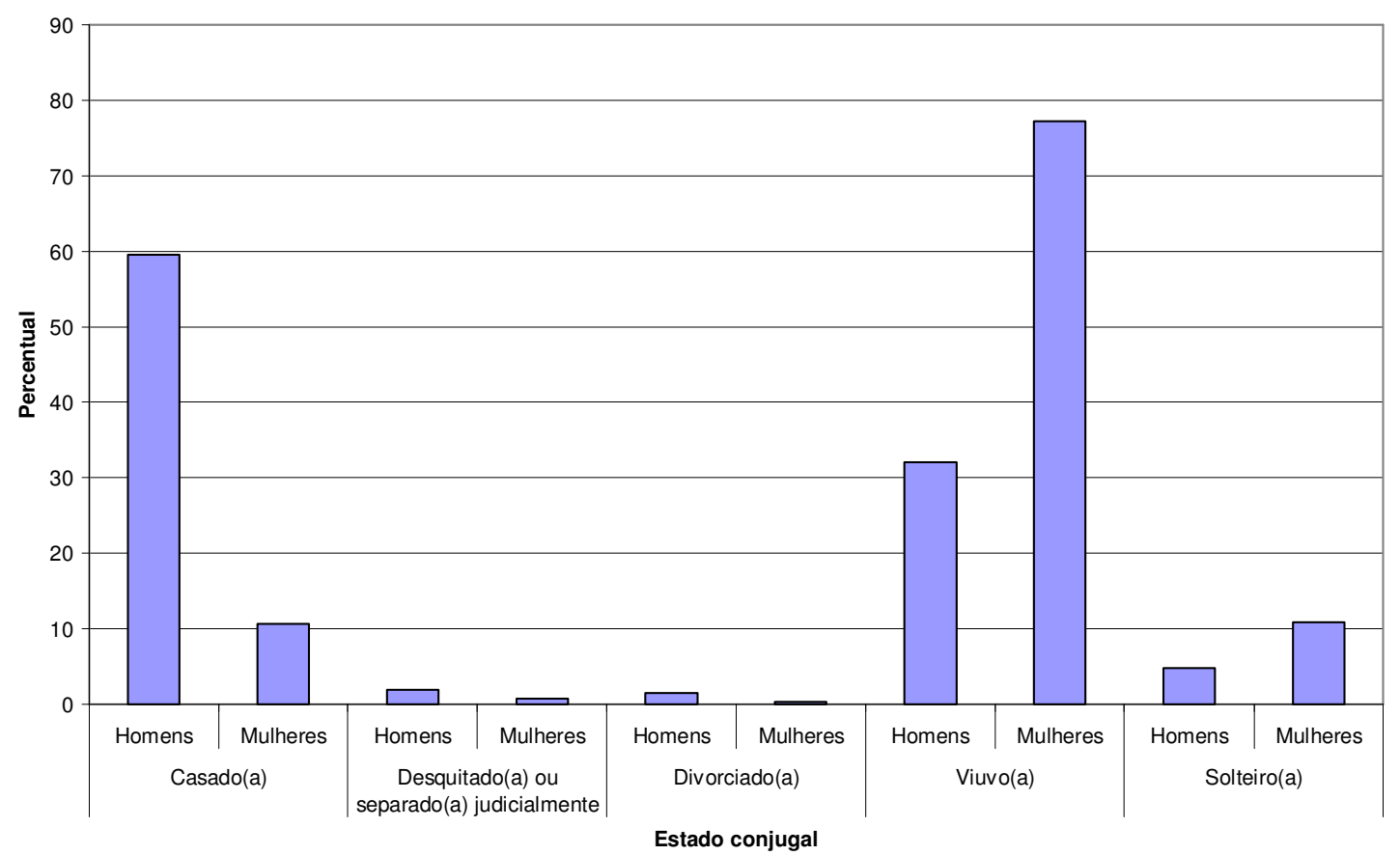

Fonte: IBGE, Censo Demográfico 2000.

Assim como na população idosa nacional, em Santos há predomínio de homens casados e de mulheres viúvas, mas a proporção de viúvas é maior: são cinco vezes mais numerosas que os viúvos no segmento de 60 a 79 anos, embora em comparação com a mesma relação de proporção no estado de São Paulo o número seja apenas um pouco acima (40,03\% no estado e 40,2\% em Santos).

O alto número de homens casados entre os idosos de mais de 80 anos ou mais, junto à grande proporção de viúvas entre as idosas da mesma faixa pode indicar a tendência de recasamento entre os homens, observada por Telles (2003). É interessante observar que entre as idosas viúvas santistas muitas têm sustento próprio e ajudam na renda da família dos filhos. Por essa renda vir, muitas vezes, de pensão por viuvez, elas evitam o recasamento, preferindo não oficializar novas uniões - assim me contaram alguns entrevistados. Isso pode explicar também a grande diferença de recasamento entre homens e mulheres (os homens não têm uma pensão por viuvez a perder). 


\subsection{Escolaridade}

A escolaridade do idoso brasileiro melhorou, principalmente entre as mulheres idosas, que em 1940 eram 74,2\% analfabetas e em 2000 são menos de 30\%. Houve aumento na quantidade de anos de estudo, sendo que o primeiro segmento de idosos (60 a 79 anos) teve mais anos de estudo acumulados que o segundo. Ainda assim, os maiores ganhos de escolaridade estão com os homens, que acumularam uma média de cinco anos de estudos contra 4,8 das mulheres. Há grande diferença na escolarização segundo os grupos etários e as regiões. Entre São Paulo e Brasil essa diferença já se destaca, mas é ainda maior com relação aos idosos de Santos, que estão com mais anos de estudo acumulados, conforme observamos no gráfico ${ }^{6}$ a seguir:

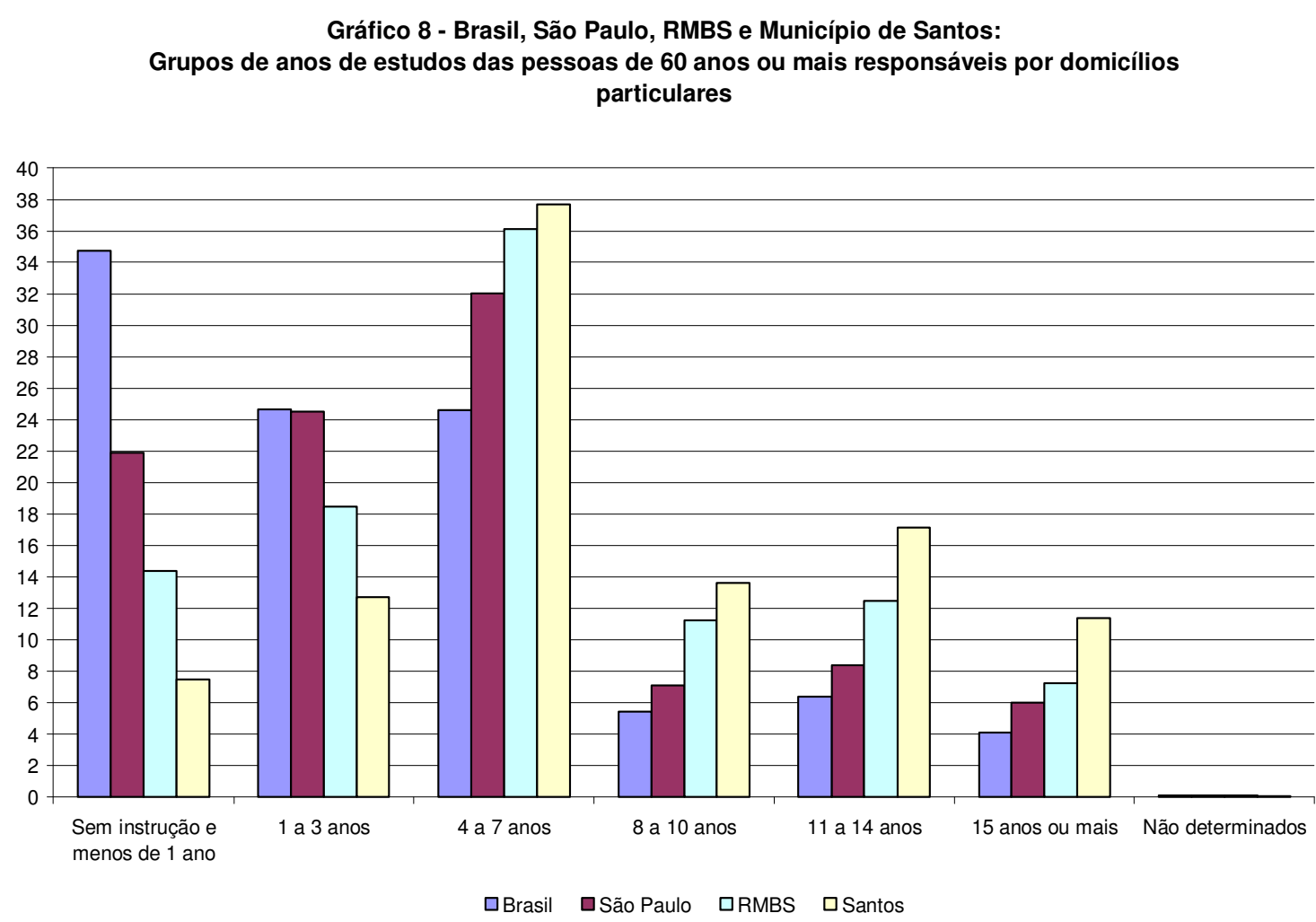

Fonte: IBGE, Censo Demográfico 2000.

Os idosos que residem em Santos têm, em média, mais anos de estudo do que a média do país ou mesmo da região metropolitana, superando-os a partir da faixa de 4 a 7

\footnotetext{
${ }^{6}$ A variável "grau de instrução" só estava disponível no SIDRA IBGE (Sistema de Recuperação de Dados Agregados do IBGE) para pessoas responsáveis por domicílio particular, e não para o total da população residente.
} 
anos de estudos. Chama atenção o alto número de idosos que tem de 11 a 14 anos de estudo, e de mais de 15 anos de estudo: nesse último intervalo, são quase quatro vezes mais que na população nacional, e mesmo dentro da sua região, quase duas vezes maior. Com esses índices, os idosos santistas podem ter tido boa trajetória ocupacional, e conseqüentemente, aposentadoria melhores. A distribuição de renda entre os idosos santistas, segue a mesma tendência, como veremos na próxima seção.

\subsection{Renda}

O rendimento do idoso no Brasil é melhor atualmente do que o da população jovem, afirma Camarano et al 2004. O estrato de menor renda entre os idosos tem renda maior do que o estrato de maior renda entre os jovens, em média. Dessa forma, os idosos têm capacidade de fornecer suporte familiar, e freqüentemente, dividem o domicílio com seus filhos e netos.

Entre 1940 e 2000 o rendimento dos idosos melhorou continuamente, embora entre os censos de 1980 e 1991 tenha diminuído. Mas a partir deste último, a proporção de idosos sem rendimentos volta a cair, principalmente entre as mulheres, que sempre foram as mais pobres. Isso se deve em grande parte à Constituição de 1988, que assegura pelo menos um salário mínimo mensal a todas as pessoas carentes acima de 65 e a universalização da previdência rural ${ }^{7}$.

A evolução do rendimento entre homens e mulheres é bem diferenciada, assim como suas trajetórias ocupacionais. O rendimento dos homens cresce até os 55 anos, quando começa a declinar, provavelmente com o início da aposentadoria, geralmente menor do que seu salário ou renda anterior. Com as mulheres os rendimentos absolutos são mais baixos; crescem até a faixa dos 45 a 49 anos, declinam até os 60 anos quando voltam a subir, atingindo o ponto máximo na faixa dos 75 a 79 anos. O rendimento feminino é, dessa forma, menos afetado pela idade, e provavelmente não está tão ligado a uma evolução ocupacional; cresce nas faixas etárias mais avançadas devido a pensões por viuvez.

\footnotetext{
${ }^{7}$ No Estatuto do Idoso, em seu artigo 34, lê-se: "Aos idosos, a partir de 65 (sessenta e cinco) anos, que não possuam meios para prover sua subsistência, nem de tê-la provida por sua família, é assegurado o benefício mensal de 1 (um) salário-mínimo, nos termos da Lei Orgânica da Assistência Social - Loas".
} 
A maior parte da renda dos idosos, ainda segundo Camarano et al (2004), vem da aposentadoria e cada vez menos de trabalho atual. Em 1980, 35,5\% da renda do idoso éramos provenientes de aposentadoria, em 2000 já são 51,3\%. Entre as mulheres a importância da aposentadoria é maior, novamente, devido ao peso das pensões por viuvez. Para as autoras, dois fatores explicam essa maior participação da aposentadoria no rendimento da população idosa brasileira: o envelhecimento da própria população idosa (o segmento mais idoso dificilmente trabalha, e vive mais da aposentadoria) e o aumento da cobertura da previdência, principalmente para as mulheres e para os idosos do meio rural.

Aumenta também a contribuição do idoso na renda da família, que em 2000 passou a responder por mais da metade do orçamento familiar $(58,5 \%)$. Neste aspecto, a relação entre envelhecimento e dependência pode tornar-se inversa, já que muitas vezes além de independentes financeiramente, podem estar ajudando os membros mais jovens da família.

Em Santos, assim como na variável escolaridade, os idosos estão com renda melhor do que a população idosa nacional, conforme os gráficos 10 e 11:

Grafico 10 - Distribuição do rendimento nominal mensal entre pessoas de 60 a 79 anos de idade responsáveis por domicílios particulares - Ano 2000

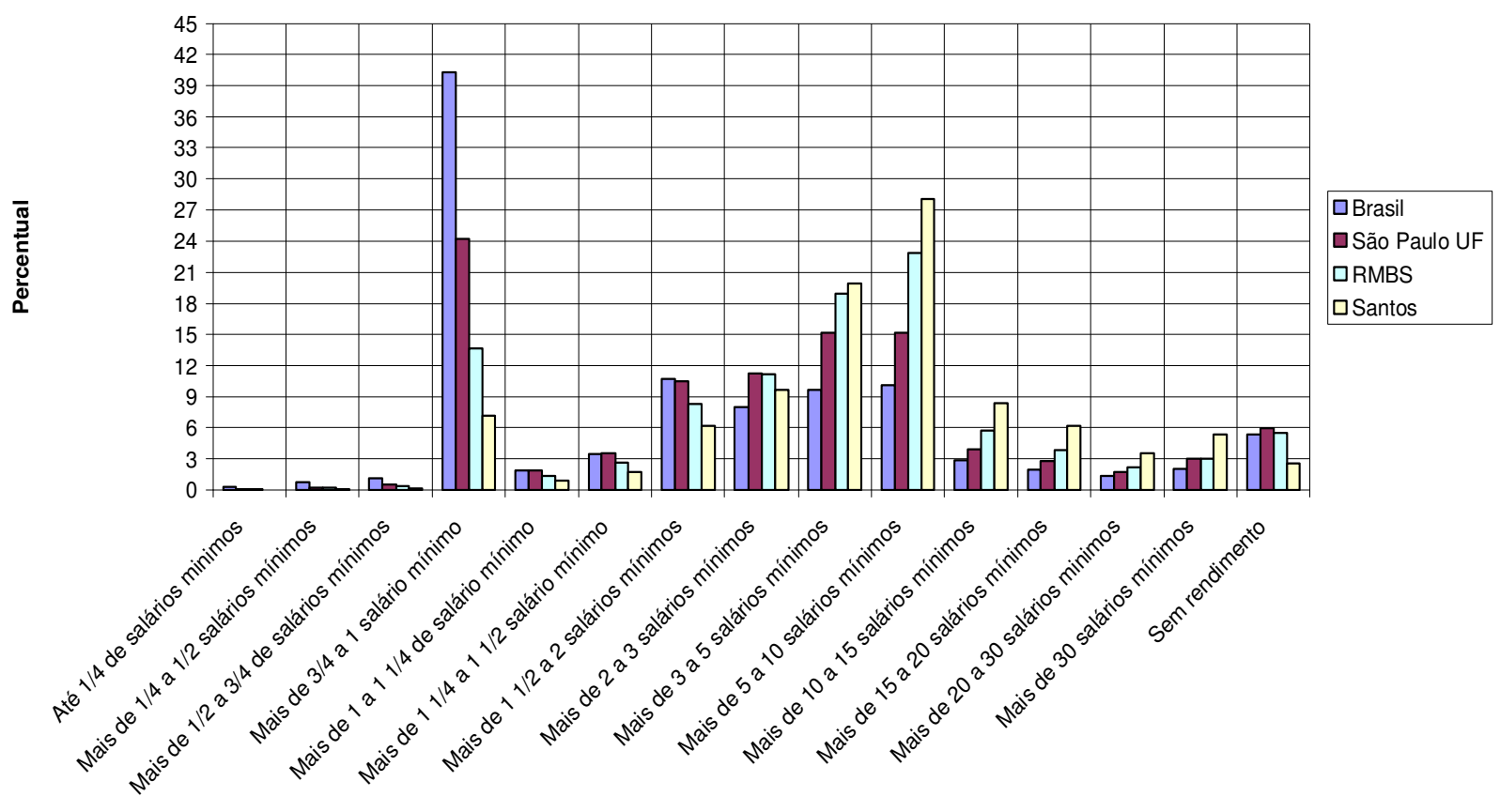

Classes de rendimento 
Gráfico 11 - Brasil, São Pulo UF, RMBS, Município de Santos: Distribuição de rendimento nominal mensal por pessoas de $\mathbf{8 0}$ anos ou mais de idade responsáveis por domicílios particulares - Ano 2000

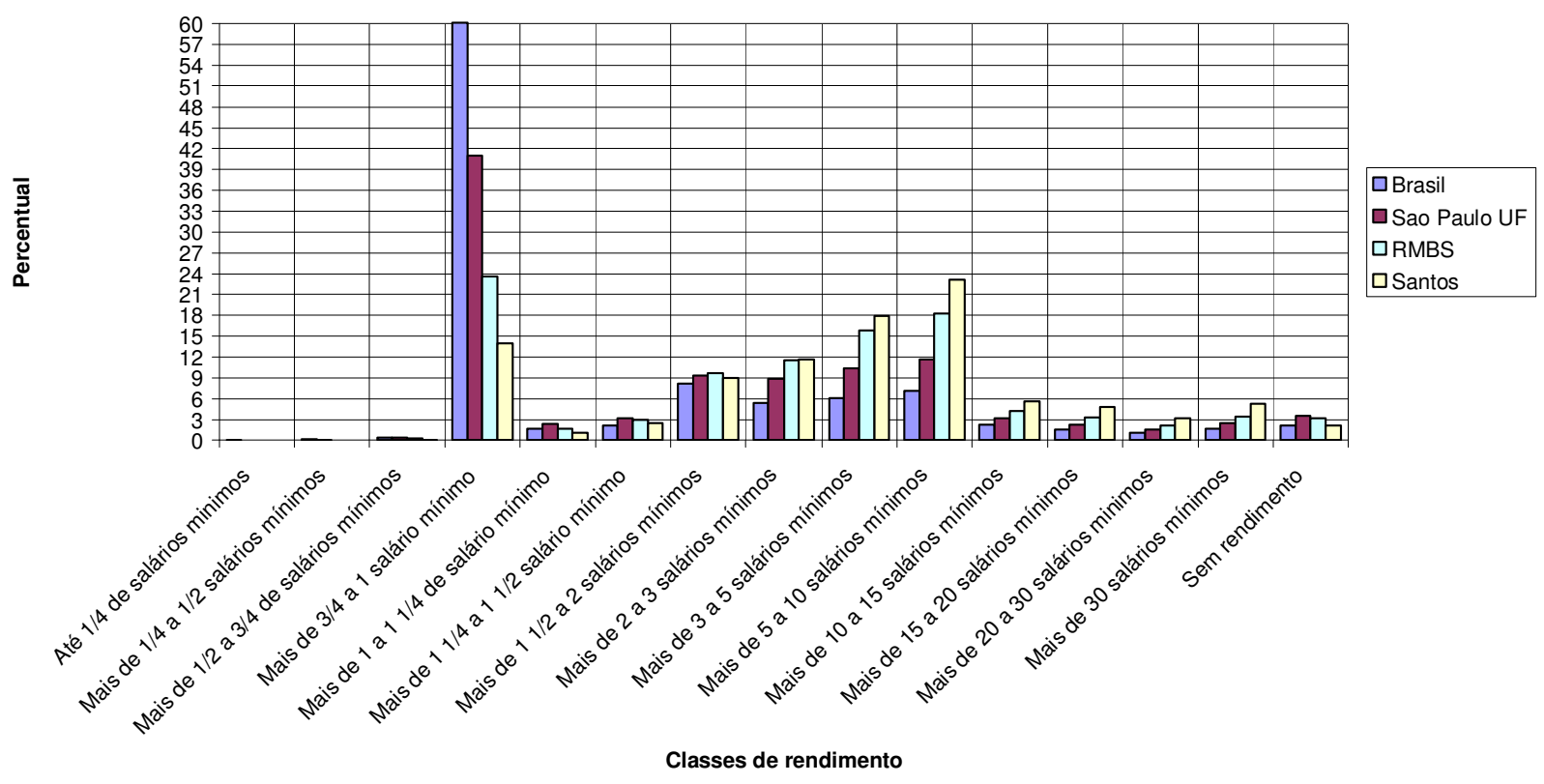

\begin{tabular}{|c|c|c|c|c|}
\hline Classes de rendimento mensal & Brasil & São Paulo & RMBS & Santos \\
\hline Até 1/4 de salário mínimo & 0,29 & 0,06 & 0,05 & 0,02 \\
\hline Mais de $1 / 4$ a $1 / 2$ salário mínimo & 0,79 & 0,25 & 0,21 & 0,08 \\
\hline Mais de $1 / 2$ a $3 / 4$ de salário mínimo & 1,16 & 0,51 & 0,37 & 0,14 \\
\hline Mais de $3 / 4$ a 1 salário mínimo & 40,29 & 24,23 & 13,63 & 7,19 \\
\hline Mais de 1 a 1 1/4 de salário mínimo & 1,88 & 1,89 & 1,36 & 0,88 \\
\hline Mais de $11 / 4$ a $11 / 2$ salário mínimo & 3,46 & 3,51 & 2,65 & 1,75 \\
\hline Mais de $11 / 2$ a 2 salários mínimos & 10,71 & 10,47 & 8,28 & 6,22 \\
\hline Mais de 2 a 3 salários mínimos & 8,00 & 11,26 & 11,20 & 9,64 \\
\hline Mais de 3 a 5 salários mínimos & 9,71 & 15,15 & 18,97 & 19,95 \\
\hline Mais de 5 a 10 salários mínimos & 10,08 & 15,21 & 22,87 & 28,10 \\
\hline Mais de 10 a 15 salários mínimos & 2,87 & 3,96 & 5,76 & 8,34 \\
\hline Mais de 15 a 20 salários mínimos & 1,98 & 2,81 & 3,87 & 6,20 \\
\hline Mais de 20 a 30 salários mínimos & 1,33 & 1,74 & 2,20 & 3,59 \\
\hline Mais de 30 salários mínimos & 2,06 & 3,00 & 3,04 & 5,40 \\
\hline Sem rendimento & 5,39 & 5,95 & 5,53 & 2,52 \\
\hline Total & 100 & 100 & 100 & 100 \\
\hline
\end{tabular}




\begin{tabular}{|l|r|r|r|r|r|}
\hline $\begin{array}{l}\text { Tabela } 3 \text { - Pessoas de } 80 \text { anos ou mais de idade responsáveis por domicílios } \\
\text { particulares e classe de rendimento nominal mensal (percentual) - Santos-SP 2000. }\end{array}$ \\
\hline Classes de rendimento nominal mensal & Brasil & São Paulo & RMBS & Santos-SP \\
\hline Até 1/4 de salários mínimos & 0,07 & 0,03 & 0,00 & 0,00 \\
\hline Mais de 1/4 a 1/2 salários mínimos & 0,18 & 0,09 & 0,04 & 0,00 \\
\hline Mais de 1/2 a 3/4 de salários mínimos & 0,38 & 0,36 & 0,20 & 0,09 \\
\hline Mais de 3/4 a 1 salário mínimo & 60,06 & 41,02 & 23,54 & 13,98 \\
\hline Mais de 1 a 1 1/4 de salário mínimo & 1,68 & 2,36 & 1,64 & 1,09 \\
\hline Mais de 1 1/4 a 1 1/2 salário mínimo & 2,13 & 3,18 & 2,93 & 2,45 \\
\hline Mais de 1 1/2 a 2 salários mínimos & 8,17 & 9,36 & 9,74 & 8,97 \\
\hline Mais de 2 a 3 salários mínimos & 5,36 & 8,80 & 11,50 & 11,62 \\
\hline Mais de 3 a 5 salários mínimos & 6,09 & 10,32 & 15,87 & 17,86 \\
\hline Mais de 5 a 10 salários mínimos & 7,16 & 11,63 & 18,23 & 23,06 \\
\hline Mais de 10 a 15 salários mínimos & 2,28 & 3,22 & 4,27 & 5,63 \\
\hline Mais de 15 a 20 salários mínimos & 1,54 & 2,22 & 3,31 & 4,77 \\
\hline Mais de 20 a 30 salários mínimos & 1,10 & 1,47 & 2,16 & 3,15 \\
\hline Mais de 30 salários mínimos & 1,70 & 2,45 & 3,33 & 5,22 \\
\hline Sem rendimento & 2,11 & 3,50 & 3,24 & 2,11 \\
\hline Fonte: Censo Demográfico IBGE, 2000. & \multicolumn{5}{|l}{} \\
\hline
\end{tabular}

Assim como na distribuição sobre grau de instrução, podemos observar que a renda dos idosos santistas é maior que a dos idosos brasileiros em média, e mesmo que a dos idosos da sua própria região. Em Santos, nos dois intervalos etários, os idosos concentramse nas faixas médias de renda entre 3 e 10 salários mínimos, sobretudo na de 5 a 10 salários mínimos, o que garante $60 \%$ de população idosa predominantemente de classe de renda média. Devemos destacar que é maior nesse caso o potencial consumidor e provedor familiar, podendo ter peso no movimento dos setores de comércio e serviços na cidade.

Em âmbito nacional há grande concentração na faixa de até um salário mínimo, acentuando-se no segmento mais idoso. Isso ocorre porque na população idosa brasileira, a velhice traz uma garantia de renda aguardada a vida toda, com o recebimento do auxílio previdenciário assegurado pela Lei Orgânica de Assistência Social (um salário mínimo).

Tanto nas distribuições do Brasil e de São Paulo, quanto na santista e na metropolitana, o intervalo etário de 60 a 79 anos tem melhor renda, o que pode ser proveniente de o que pode ser proveniente de uma permanência de aposentados no mercado de trabalho ou de trabalhadores dessa faixa etária na economia informal, já que é mais difícil para os idosos de 80 anos ou mais continuarem no mercado. No entanto, é interessante destacar que nas distribuições do Brasil e de São Paulo a desigualdade de renda é acentuada 
na faixa mais idosa, ao contrário do que ocorre na distribuição santista, o que pode ser um reflexo de uma renda melhor distribuída já nas faixas etárias anteriores.

Grau de instrução e renda são fatores que pesam nas condições de vida da população e para os velhos são ainda mais importantes no acesso aos cuidados que precisam (mais caros e constantes do que aqueles exigidos pelos jovens e adultos). É verdade que a família é a instância cuidadora decisiva no bem-estar do idoso, mas é crescente também o número de serviços privados para essa população, que tem mais recursos e mais necessidades de gastos do que a população jovem. Além disso, pelos gráficos anteriores sabemos que os idosos de Santos, além de terem melhor renda e grau de instrução, são comparativamente mais jovens, indicando uma população com maior probabilidade de autonomia física, portanto, com mais poder de participação na produção de localizações urbanas na cidade.

Acreditamos que o envelhecimento populacional é mais acentuado em Santos porque é também um dos processos resultantes da formação da estrutura urbana dessa cidade. Por isso é preciso investigar como se formou essa população e como a própria estrutura urbana de Santos se constituiu. Seriam esses idosos de Santos a população residente que envelheceu e construiu, ela mesma, a estrutura urbana da cidade ou são, em parte, população idosa que chegou depois, proveniente tanto de outras unidades de federação, como da própria região metropolitana?

\subsection{Formação da população idosa santista}

O estudo da formação da própria estrutura urbana da cidade enquanto o conjunto dos processos que organizam seu tecido urbano ${ }^{8}$ demonstrará que o envelhecimento populacional que se observou é resultado dessa própria estruturação intra-urbana e urbanoregional. Para Alberto Jakob, que em sua tese de doutoramento analisou demograficamente a constituição urbana da Região Metropolitana da Baixada Santista, o envelhecimento

\footnotetext{
8 "Tecido urbano", "mancha urbana" são expressões que utilizamos para designar puramente o espaço de assentamento da cidade, a área urbanizada, o próprio espaço intra-urbano.
} 
populacional santista é resultante do comportamento passado dos fluxos migracionais que constituíram a população da região ${ }^{9}$.

A análise dos dados da população de Santos dos Censos de 1970 até 2000 mostra um aumento contínuo na taxa de longevidade e queda na taxa de mortalidade. Isso indicaria um envelhecimento populacional "natural", sem necessária entrada de migrantes idosos ou saída de migrantes jovens. De acordo com Jakob (2003), o envelhecimento populacional de Santos já vem desde 1980, quando $21 \%$ dos casais residentes estavam acima dos 60 anos de idade, e ainda, quase a metade dos casais residentes com idade média de 45 anos ou mais. Porém, a migração é um forte fator nesse processo, pois Santos foi um dos primeiros municípios do Brasil a ser alvo de fortes surtos de migração: primeiro a migração internacional na época do intenso comércio do café; depois, nos anos 1950 e 1960, a migração interna (intra-estadual, interestadual (nordestinos em sua maioria) e intrametropolitana) com a demanda de mão de obra das empresas de construção civil que erguiam os prédios da orla da praia, e ainda a demanda de mão de obra do complexo industrial de Cubatão, cidade que não tinha infra-estrutura suficiente para abrigar a mão de obra qualificada.

No entanto, Santos foi também o primeiro município a diminuir essa migração e o primeiro a ter saldos cada vez menores na migração intra-metropolitana ("expulsando" população para os municípios vizinhos). Já a partir de 1980 a cidade passou a receber menos gente do que mandava para fora. E os poucos que ainda chegavam eram mais velhos do que os emigrantes, constituindo migração de retorno daqueles que, depois de certo período de trabalho, podiam melhorar suas condições residenciais, deixando os municípios periféricos ${ }^{10}$, ou, dito de outra forma, como num processo metropolitano de sucessão entre zonas urbanas, como veremos. Já na década de 1980 a população migrante era envelhecida em relação à das

\footnotetext{
${ }^{9}$ Esse trabalho de Jakob (2003) será utilizado também no capítulo terceiro, sobre a estruturação de Santos. Os dados que serão apresentados a seguir foram elaborados por este autor através do exame dos Censos Demográficos de 1960, 1970, 1980, 1991 e alguns dados do Censo 2000, da FIBGE.

${ }^{10}$ Quando mencionamos a migração de retorno (quando o migrante retorna ao seu município de nascimento) não estamos pensando em migrantes aposentados, mas assim em famílias que ainda estão no meio de seu ciclo vital, como estudou Cunha (1994). Para Jakob (2003) "a migração de retorno não apresentou nenhum impacto significativo no processo de envelhecimento populacional observado no município de Santos” (p.120).
} 
décadas anteriores. Além disso, os municípios periféricos ${ }^{11}$ estavam em franco crescimento, oferecendo novas oportunidades de trabalho e residência. A migração das famílias jovens, tanto a migração intra-metropolitana, como aquela migração intra-estadual e interestadual (nordestinos) que outrora se dirigia a Santos, passou a se concentrar nesses municípios, e não mais em Santos, já com urbanização consolidada, e custo do espaço cada vez mais alto.

Pela estrutura ocupacional da população das cidades da RMBS elaborada por Jakob, nota-se que em Santos é mais alto o número de empregadores, aposentados e pensionistas, sobretudo na população residente. Desde o período de 1959 a 1970 Santos é a cidade que contém maior número de aposentados na sua população. Enquanto a média da RMBS nesse período era de $4,7 \%$ de população aposentada, Santos já dispunha de $6 \%$. Comparando com os municípios centrais da RMBS, Santos estava bem acima, pois São Vicente possuía 4\%, Praia Grande 3,6\% e Guarujá 1,9\% de população aposentada nesse período, em média ${ }^{12}$.

$\mathrm{O}$ crescimento do número de aposentados em relação às outras categorias de ocupação (empregado e empregador) na década de 1960 se explica, ao nosso ver, pelo Decreto No 3087 de 1960 que institui a aposentadoria especial. Em linhas gerais, esse decreto permitia aos trabalhadores submetidos a condições insalubres, penosas ou perigosas, segurados pela previdência social há pelo menos 25 anos e com 50 anos ou mais de idade aposentar-se. Em 1964 o Decreto No. 53.831 de 25 de março especificava as categorias profissionais que teriam direito a aposentar-se com 25 anos de contribuição, a chamada aposentadoria especial. Dentre elas, muitas que em Santos eram numerosas como os próprios trabalhadores portuários (estivadores, conferentes, motorneiros), operários de construção de navios, pescadores, trabalhadores em metalúrgica e siderurgia e outros. Por isso, já na década de 1960 Santos podia destacar-se com alto número de aposentados ${ }^{13}$.

\footnotetext{
${ }^{11}$ Nesse estudo dividiremos os municípios da RMBS em dois grupos: os municípios centrais (Santos, São Vicente, Cubatão, Praia Grande, Guarujá e Bertioga) e os municípios periféricos (Peruíbe, Itanhaém e Mongaguá), divisão também utilizada por Carriço (2002) e Jakob (2003). Como se verá ao longo do trabalho, esses dois grupos diferenciam-se não só geograficamente, mas também no seu modo de ocupação e na circulação de pessoas. Pode-se dizer que a área urbana regida pela estrutura urbana que atua em Santos compreende todos os municípios centrais, com exceção de Bertioga, já mais distante para deslocamentos diários.

${ }^{12}$ Grande parte da classe trabalhadora de Santos está no Porto, e algumas categorias profissionais portuárias têm direito á aposentadoria especial por se tratar de um trabalho insalubre e perigoso. Daí talvez uma explicação da precocidade da cidade em ter um grande número de aposentados.

${ }^{13} \mathrm{Em} 1968$ esse decreto foi revogado, e depois, em 1979 regulamentado novamente, como explica Freitas, 1998. Depois de muitas alterações quanto às exigências para que o trabalhador tenha o direito ao benefício
} 
Nos anos 1980 essa proporção continua aumentando: 11\% de aposentados entre a população residente, correspondendo já a mais de 30.200 pessoas. Entre a população total (contando também os migrantes), os aposentados eram 9,8\% em 1980. Em 1991, já são $13 \%$, correspondendo a 47.300 pessoas.

Jakob nota que até entre os migrantes o número de aposentados cresce; tornam-se quase quatro vezes mais entre os anos 1960 e 1970: de 2,4\% na década de 1960, para 9,1\% da população migrante na década de 1970 , e aumenta para $13,2 \%$ no período entre 1981 e 1991. A proporção de aposentados é sempre mais alta entre os não migrantes, mas devemos lembrar que os aposentados migrantes do período de 1959 a 1970, no censo de 1980 já são considerados não migrantes, a não ser que tenham saído de Santos, o que é pouco provável, dado o número maior da população.

O imaginário construído acerca de uma velhice ativa na cidade é divulgado na mídia local como um fator de atração de aposentados e já se incorporou essa idéia no senso comum da região. Tanto que há trabalhos acadêmicos da região que ressaltam Santos como uma cidade atrativa de aposentados pela sua qualidade de vida ${ }^{14}$ e a pesquisa de emprego e desemprego realizada trimestralmente pela UNISANTA colocou dentre seus objetivos específicos averiguar migração de aposentados. De fato, as pesquisas demonstram uma contínua entrada de aposentados na cidade, constatando em setembro de 2003 que dos 369 entrevistados, 14, ou seja, 3.8\% migraram para Santos no momento da aposentadoria, ou depois, num "índice praticamente igual ao apurado em março de 2003" (NESE-UNISANTA, 2006). Nas pesquisas seguintes (realizadas semestralmente) esse índice manteve-se, em média, em $3 \%$.

No estudo de Jakob também foi avaliada essa hipótese, e o autor apontou que a migração idosa foi mais sentida nos municípios periféricos da RMBS (10,8\% dos migrantes não-metropolitanos em Itanhaém e 14,6\% em Mongaguá) do que nos centrais. A exceção foi Praia Grande, o único entre os municípios centrais a ter taxa expressiva de migração não-

(como o tempo de exposição aos agentes prejudiciais, por exemplo) a legislação em vigor continua beneficiando (ainda que de maneira dificultosa ao trabalhador) as categorias mencionadas.

${ }^{14}$ A conclusão de Elias Haddad da sua dissertação em Gestão de Negócios, foi a de que " a qualidade de vida de Santos, comprovada nesse trabalho, pode atrair novos moradores e consequentemente gerar desenvolvimento econômico. Essa é uma peculiaridade da nossa cidade que, se potencializada, pode impulsionar o seu desenvolvimento, que se pretende, seja sustentável”. (HADDAD FILHO, 2004). 
metropolitana de idosos (12,8\%). No entanto, entre os anos de 1981 e 1991 a participação dos aposentados na estrutura ocupacional de Santos cresceu, especialmente entre os não migrantes, conforme já mostramos acima. Para o autor "significa envelhecimento de sua população, em grande parte devido ao seu alto volume de emigrantes que se dirigem para São Vicente e Praia Grande” (Jakob, 2003, p.101).

O IPAT $^{15}$, instituto de pesquisas de mercado do jornal local, inaugurou seus trabalhos com uma "pesquisa sobre a terceira idade" em Santos e em quatro cidades de seu entorno, para averiguar, dentre outras questões, se Santos recebia muitos migrantes idosos. O objetivo principal da pesquisa ${ }^{16}$ foi conhecer a população idosa que seria público alvo de um programa de televisão. Foram entrevistadas quase 3500 pessoas em todos os bairros de Santos, Guarujá, Praia Grande, Cubatão e São Vicente, municípios centrais da RMBS, que compõem os deslocamentos da população idosa que circula em Santos, de acordo com o que observamos em nossa pesquisa de campo.

No relatório disponibilizado no site do instituto há dados agregados ou separados por cidade. Vimos, então, que a cidade que tem mais idosos migrantes é Praia Grande, e não Santos, como se pensava, embora Santos ainda seja a cidade que mais tem idosos na região. Essa notícia foi o destaque do jornal ao publicar a pesquisa, salientando que mais da metade $(53,3 \%)$ dos idosos entrevistados em Santos, são naturais da cidade. Dos outros 46,7\% que não são naturais, a maioria está residindo na cidade há mais de dez anos e veio por motivos de trabalho, embora haja a parcela daqueles que vieram há menos de cinco anos depois de aposentar-se. É importante salientar que essa última parcela tem se demonstrado sempre presente.

Além de migração idosa, Praia Grande dispõe do maior saldo migratório positivo ${ }^{17}$ da população entre as cidades da RMBS, de acordo com Jakob (2001). Junto com o saldo migratório negativo de Santos, Jakob (2001) indica uma migração intra-metropolitana centrífuga. No seu estudo posterior, o mesmo autor nos mostrou que essa migração intra-

\footnotetext{
${ }^{15}$ Instituto de Pesquisa A Tribuna

${ }^{16}$ Assim como no IBGE, nessa pesquisa foi considerada idosa toda pessoa com 60 anos ou mais.

${ }^{17} \mathrm{O}$ saldo migratório é a diferença entre a população que veio residir no município e a que saiu no ano pesquisado. Quando é positivo, mais pessoas chegaram do que saíram.
} 
metropolitana produz envelhecimento em Santos, pois os que saem são mais jovens. O quadro abaixo, produzido pelo IPAT, mostra a migração em toda a região analisada.

1. Hà quanto tempo mora na cidade?

\begin{tabular}{|l|r|}
\hline \multicolumn{1}{|c|}{ Tempo } & $\%$ \\
\hline Menos de 1 ano & 2.1 \\
\hline De 1 a 2 anos & 2,2 \\
\hline De 3 a 5 anos & 4,1 \\
\hline De 6 a 10 anos & 6,3 \\
\hline De 11 a 20 anos & 6,9 \\
\hline Mais de 20 anos & 32,6 \\
\hline Nasci e sempre morel na cidade & 44,7 \\
\hline Ná sel Năo Lembro & 11 \\
\hline Total & 100,0 \\
\hline
\end{tabular}

1.1 Para quem não nasceu na cidade. Por que veio morar na cidade?

\begin{tabular}{|l|c|}
\hline \multicolumn{1}{|c|}{ Motivo } & $\%$ \\
\hline Para trabalhar aqui & 51,3 \\
\hline Depois de aposentar-me & 22.2 \\
\hline Outra razao & 20,5 \\
\hline Total & 100,0 \\
\hline
\end{tabular}

\subsection{Outra razão para vir morar na cidade}

\begin{tabular}{|l|r|}
\hline \multicolumn{1}{|c|}{ Motivo } & $\%$ \\
\hline Morar com parentes & 40,4 \\
\hline Saude e Qualidade de Vida & 22,3 \\
\hline Conjuge & 12.8 \\
\hline Casa propria & 6,9 \\
\hline Filhos & 0,6 \\
\hline Pais & 6,1 \\
\hline Vuvez & 50 \\
\hline Total & 100,0 \\
\hline
\end{tabular}

2. Você è aposentado?

\begin{tabular}{|l|c|}
\hline Aposentado & $\%$ \\
\hline Sim & 75.7 \\
\hline Nâ & 243 \\
\hline Total & 1000 \\
\hline
\end{tabular}

Fonte: IPAT, 2005 
De todos os entrevistados da região, $16,7 \%$ são migrantes, e $22 \%$ dos idosos não naturais chegaram a Santos depois de aposentar-se. É um número considerável e muito maior do que o apurado por Jakob 2003. Nesse caso, a diferença de amostra pode ser fundamental, pois como veremos, há grandes diferenças entre os idosos de cada bairro de Santos, ou seja, de acordo com os bairros visitados pelo IPAT, esse número pode aumentar ou diminuir.

Mas a grande migração idosa constatada ficou por conta do município de Praia Grande. O boom de apartamentos de veraneio de Praia Grande aconteceu depois da edificação da maior parte dos prédios da orla de Santos, como se fosse uma alternativa barata àquelas terras já especuladas. Da mesma forma, idosos da classe média vêem em Praia Grande oportunidades imobiliárias já ausentes de Santos, ou a chance de transformar seus apartamentos e casas de veraneio em moradia. Em entrevistas em Santos, esses casos foram recorrentes, assim como entrevistamos idosos que moravam em Praia Grande realizando atividades lúdicas no $\mathrm{SESC}^{18}$ de Santos, no hipermercado Extra ${ }^{19}$, e em outros pontos de encontro que listaremos no quarto capítulo. Entrevistamos também em Santos, senhoras que moravam em Praia Grande, São Vicente e até Guarujá, que desejavam residir em Santos. Dessa forma, mesmo não sendo pólo de atração migratória, Santos sente os efeitos dessa migração.

Assim, analisar a produção de localizações urbana em Santos por idosos, não significa analisar somente os idosos habitantes da cidade de Santos. Os deslocamentos intrametropolitanos acontecem também entre a população idosa ${ }^{20}$. Santos é o centro das trocas urbanas dessa grande área intra-urbana, ou seja, a estrutura urbana que organiza o seu cotidiano é um conjunto de fluxos populacionais que não se conforma aos limites administrativos da cidade, sendo a população idosa de toda a área, um motor dessa

\footnotetext{
${ }^{18}$ O Serviço Social do Comércio (SESC) é uma entidade de direito privado resultante das políticas sociais da Confederação Nacional do Comércio e está instalado em Santos em uma grande construção que abriga um complexo de espaços de esporte e lazer além do teatro, assim como em outras cidades no país. No Brasil, o SESC foi a instituição pioneira em trabalhar de maneira focada a um público de mais de 60 anos, inaugurando o incentivo à Terceira Idade como concepção de envelhecimento saudável e ativo.

${ }^{19}$ Há um único hipermercado Extra em Santos, que fica no entroncamento de duas importantes avenidas (Francisco Glicério e Ana Costa) e uma artéria local (a Rua Pedro Américo). No capítulo 4 veremos como esse supermercado tornou-se um lugar de concentração de idosos ao promover um baile de dança de salão.

${ }^{20}$ Essa afirmação só pode ser corroborada pela nossa pesquisa de campo, e por isso não oferecemos nenhuma taxa, pois nossa amostra foi aleatória.
} 
estruturação urbana que se faz dia a dia. Mas nesse trabalho somente a população idosa santista será estudada, não só para que a pesquisa possa se realizar, mas também porque o espaço intra-urbano de Santos, estruturado de maneira cada vez mais segregadora, tem sido seletivo até mesmo para essa população, delineando um envelhecimento populacional bastante particular, como vimos nos parágrafos anteriores.

A formação dessa área intra-urbana, e como se organizou a estrutura urbana atual é o objeto do terceiro capítulo, não sem antes visitar as ferramentas teóricas para essa análise. 


\section{Capítulo 2: Teorias da estrutura urbana}

A presença dos idosos na cidade de Santos, seja pela circulação ou pela residência, vem, aos poucos, produzindo ou transformando algumas localizações urbanas enquanto espaços de vivência e sociabilidade. Para entender esse processo é necessário discutir teoricamente a produção social do espaço urbano. Adotamos o conceito de Flávio Villaça de espaço intra-urbano por ter sido o que melhor captou essa dimensão espacial do cotidiano citadino. Os pressupostos teóricos e os conceitos clássicos do estudo do espaço urbano formam a base para a teoria de Villaça (1998), que, a nosso ver, conseguiu fornecer um esquema de análise do espaço constitutivo das metrópoles, e não uma abordagem do espaço regional.

Nesse capítulo nosso objetivo é visitar brevemente os principais conceitos que se utilizam nos estudos sociológicos urbanos buscando iluminar nosso objeto de estudo: a relação entre a população idosa e a estruturação do espaço intra-urbano de Santos.

Num primeiro olhar, cremos que os efeitos de um crescimento da proporção da população idosa na produção social do espaço ainda não são suficientemente contemplados por teorias que enfatizem a distribuição dos meios de produção e da força de trabalho como principal motor da produção do espaço urbano. No nosso caso, estudamos um grupo populacional que não se encaixa em nenhuma dessas categorias ${ }^{21}$. Para isso seria necessária uma incursão em teorias sociológicas que procuram explicar não só a produção do espaço urbano, mas também a sua organização, oferecendo acurada descrição do comportamento dos grupos sociais na cidade e das suas características culturais próprias, relevantes para $a$ estruturação do espaço da cidade. A Escola de Chicago foi a que iniciou este mergulho teórico e empírico nos estudos urbanos (Eufrásio, 1999) e cunhou o importante conceito sociológico de estrutura urbana. Ela representa o início dos estudos da cidade enquanto um sistema social de escala própria, no qual os "fatos sociais" da sociedade moderna se revelam.

\footnotetext{
${ }^{21}$ Embora os idosos aposentados já tenham sido força de trabalho e haja grande parte daqueles que ainda trabalham, não é como força de trabalho que usufruem a cidade, como veremos adiante.
} 
Por outro lado, não podemos deixar de considerar que no sistema capitalista o espaço deve ser considerado como mercadoria, sendo disputado por classes sociais, como lembra Lefebvre (1991). Castells (2000), em uma pretensa crítica a Escola Sociológica de Chicago, assinala que a cultura urbana a qual Park buscou não pode ser considerada uma variável independente dos processos econômicos, políticos e ideológicos que estruturam a própria sociedade capitalista como um todo. Nesse sentido, nossa pesquisa se assenta sobre os pressupostos teóricos construídos pelos principais teóricos em estudos urbanos da Escola Sociológica de Chicago (Ernest Burgess e Robert Park) e também pelo economista Homer Hoyt, mas procura não deixar de observar as considerações do debate marxista da produção social do espaço da sociedade capitalista, indispensáveis para analisar qualquer formação urbana consolidada, principalmente as metropolitanas.

Já se encontram esboços de uma concepção de estrutura urbana em Engels, n'A Situação da Classe Trabalhadora na Inglaterra e na obra de Johann Georg Kohl, geógrafo que já no século XIX, teria anunciado certas teses que somente no início do século XX seriam desenvolvidas, como a relação de referência mútua entre a área comercial e a residencial, e a sua teoria da expansão da cidade a partir da busca do campo pelas elites (Peucker, 1968:03). Entretanto, foram Robert Park e Ernest Burgess os primeiros sociólogos a delinear um campo de estudos urbanos dentro das ciências sociais.

\subsection{A Escola Sociológica de Chicago}

Mário Eufrásio (1999) analisou sociologicamente a formação da Escola Sociológica de Chicago com foco nas suas construções teóricas sobre a cidade. Para esse autor é possível classificar tais contribuições teórico-metodológicas em duas linhas principais. A primeira seria a "vertente ecológica" e a segunda Eufrásio chamou de "concepção sócioeconômica", ambas buscando compreender o desenvolvimento da cidade utilizando o conceito de "estrutura urbana". No entanto o mesmo autor explica que a proposição de um estudo sobre a cidade veio antes de uma teoria urbana (Eufrásio, 1995, 1999). É preciso, portanto, analisar o breve período de formação da própria sociologia norte-americana para compreender as bases e a motivação do programa de investigação proposto por Robert 
Park, que veio a gerar a sociologia urbana de Chicago como uma corrente teórica. Dessa forma, averiguando os objetivos dos primeiros autores, entenderemos as contribuições do método de pesquisa que faz da Escola Sociológica de Chicago uma iniciativa ímpar nos estudos urbanos, relevantes até hoje.

As primeiras empresas investigativas que tentaram explicar a explosão moderna que agitava as cidades americanas motivaram o próprio nascimento da sociologia, enquanto uma disciplina, nos Estados Unidos. Quase de repente, vultosas somas de dinheiro transformavam ou criavam quarteirões inteiros naquele momento histórico de construção do país. Vilas de agricultores davam lugar a cidades comandadas por magnatas e movimentadas por muitos operários de nacionalidades diversas, explorados à exaustão. Invenções tecnológicas, a luz elétrica e o vapor facilitavam a vida cotidiana, e o consumo aumentava bem como a população que chegava em busca de trabalho e de ascensão social. A cidade crescia sem planejamento algum ou leis reguladoras, dando abrigo à "delinqüência" e ao crime. Em meio a esse estado quase anômico, se visto de longe, alguns homens vindos de uma sociedade rural, sentem o estranhamento e tentam entender aquele aparente caos.

Os primeiros sociólogos, assim como boa parte da população norte-americana daquela época, têm quase todos uma origem rural, com uma sólida crença protestante, a qual via na religião uma forma de compreender e explicar o mundo. Segundo Coser (1980) e Hinkle (1954), autores que analisaram o nascimento da sociologia nos Estados Unidos os primeiros sociólogos norte-americanos conviviam com o espírito reformador e moralista do "Movimento da Reforma", um movimento de reação à súbita e intensa industrialização, que abandonava valores tradicionais. Largamente difundido naquela época, esse movimento incitou uma crítica aos valores daquela sociedade moderna que se formava, motivando a criação da própria Sociologia como uma ciência dedicada a investigar os problemas sociais que se avolumavam. De maneira geral, naquela época, esses pensadores buscaram formar uma ciência que explicasse e predissesse a mudança social, mas comprometidos eticamente “com o melhoramento das condições sociais urbanas" (Hinkle, 1954, p.3). Segundo Coser (1980), “os primeiros cursos de sociologia, quer oferecidos pelos presidentes de faculdades ou por jovens professores, tendiam a ser uma variada combinação de exortação moral, 
descrição factual, problemas sociais, darwinismo conservador ou reformista, movimento cristão, economia institucional e preocupação com várias formas de patologia social”.

O Departamento de Sociologia da Universidade de Chicago foi o que mais avançou cientificamente na disciplina, sendo em certa altura quase o representante da sociologia americana como um todo. Mas antes dele, outras tentativas de explicar os problemas sociais já tinham sido realizadas, embora a maioria ainda não primasse por um método científico. $\mathrm{O}$ primeiro trabalho comprometido com a compreensão sociológica, e não com a reforma social foi Folkways, de Sumner, que veio a ser utilizado como ponto de partida pelo grande líder da Escola Sociológica de Chicago, Robert Park.

Como disse Coser (1980), o subtítulo do livro de Sumner - "Estudo da Importância Sociológica dos Usos, Maneiras, Hábitos, Costumes e Moral" diz em grande parte do que se trata: uma tentativa de delinear uma teoria geral da sociedade humana por meio de categorias de comportamento humano. Os principais conceitos dessa obra são os folkways e os costumes (os “mores”). Os folkways são as maneiras habituais de fazer as coisas, aprendidas por "tentativa e erro" desde o começo da civilização. Quando esses folkways se demonstram as melhores maneiras de lidar com as atividades cotidianas, são transformados em costumes. Os costumes são hábitos mais carregados de significado cultural, ou como disse Coser mais adequadamente, "podem tornar qualquer coisa certa (...) são coercivos e se impõem. (...) Enquanto as sanções contra os desvios dos folkways podem ser relativamente moderadas, as sanções pelas infrações dos costumes são mais rigorosas, precisamente porque são consideradas uma garantia de bem estar do grupo" (Coser, 1980, p. 390).

Sumner também atribuiu significado à idéia de instituição, que era uma conseqüência dos outros dois conceitos: quando os folkways que haviam se transformado em costumes e ganhavam uma representação material, teríamos, então, uma instituição. Havia instituições naturais, que tinham se desenvolvido lentamente, como o casamento, e instituições “criadas", produtos de um mundo moderno, de uma invenção racional, como os bancos. Ambos eram instituições porque eram idéias válidas para toda a sociedade, dotadas de uma estrutura material. Com isso, Sumner queria mostrar como havia uma evolução da sociedade, e que qualquer interferência que não respeitasse as instituições, os costumes e os 
folkways, tenderia ao fracasso. Essas idéias subjazem a primeira investida em pesquisa urbana de Park.

É consenso entre os sociólogos que estudaram a Escola de Chicago como uma escola teórica $^{22}$ que William G. Sumner, Lester F. Ward, Albion W. Small, Franklin G. Giddings, Edward A. Ross, Charles H. Cooley foram os seis pais fundadores da sociologia norte-americana. William Thomas e Robert Park, da segunda geração, foram decisivos porque consolidaram a sociologia como disciplina científica com perspectiva própria, sem ser o estudo apenas dos problemas sociais. Os desdobramentos de suas obras foram mais do que teóricos, mas também institucionais e acadêmicos.

Desses teóricos, o mais importante para nós é Robert Park, professor da Universidade de Chicago que buscava captar e analisar os elementos principais de um modo de vida urbano. Em 1915, motivado por suas observações empíricas sobre a cidade de Chicago e, segundo Eufrásio (1999), pelo estudo das obras de Sumner, Simmel, Durkheim, Cooley e principalmente de The Polish Peasant, de William Thomas, Park propõe um programa de investigação que objetiva não só estudar a cidade de Chicago, mas apreender o que é comum a todas as cidades: a cultura urbana. Assim como a antropologia cultural de Franz Boas estudava culturas de outras sociedades, a cultura urbana também deveria ser tomada como objeto de estudo antropológico, pois possuía, em si, um modo de vida próprio.

Para Park, a cidade é mais do que "um mero agregado de organizações sociais" (Eufrásio, 1999:49), é uma organização natural, cultural, moral e econômica. O seu espaço - edifícios, ruas, praças, escolas, igrejas - é resultante do comportamento dos seus indivíduos, mas em conjunto, forma um todo que age sobre eles, gerando a cultura urbana. A sua materialidade é organizada em uma estrutura que resulta de processos naturais de interação entre os homens; é um conjunto organizado, que "se estrutura por certa associação entre seus elementos e resulta de um processo (...) não intencional de trabalho de sucessivas gerações de homens" (Park, 1915, p.29-30 in Velho, 1976). Ou seja, a cidade é uma construção histórica, mas acontece naturalmente, assim como explicou Sumner sobre a transformação dos folkways em instituições.

\footnotetext{
${ }^{22}$ Ver Hinkle (1980), Coser (1980), Bulmer, (1984), Eufrásio (1995 e 1999), entre outros.
} 
Tal como Durkheim imaginou a sociedade, a cidade é um organismo composto de várias partes, engendrado pela interação da organização física, com uma "ordem moral",23 e uma organização econômica. Cada parte desse organismo possuiria uma função e um espaço, formando as áreas naturais e especialmente as vizinhanças.

Dessa forma, muito do que era tratado como problema social por outros pesquisadores, para Park, eram características naturais da cidade e deviam ser compreendidas dentro daquele todo articulado. O objetivo de seu artigo, portanto, era propor um programa de investigação que, por meio de diversas indagações, visaria fundamentalmente desvendar os processos e fatores que formam a cidade, tentando explicála primeiramente, e não imediatamente resolver seus problemas.

$\mathrm{O}$ artigo de Park está dividido em quatro seções, que são os temas principais a ser investigados: 1) "A organização local e o plano da cidade", 2) "A organização industrial e a ordem moral", 3) "As relações secundárias e o controle social" e o 4) "O temperamento e o meio urbano" (Park, 1915 in Velho 1976).

No decorrer da primeira seção Park intuiu uma idéia de uma estrutura urbana, que seria formada pela interação entre a organização física e a ordem moral dos indivíduos no espaço da cidade, como sugerimos nos parágrafos acima. Para o autor a organização física revela que a cidade é composta por um conjunto de áreas naturais, ou seja, de "regiões" de diferente composição, função e caráter social na cidade. Essas regiões ou áreas, por sua vez, são formadas por vizinhanças, isto é, por conjuntos de construções (residências, estabelecimentos comerciais) ocupando, geralmente, o espaço de um quarteirão ou pouco mais, onde há uma espécie de "homogeneidade moral", impressa por seus habitantes:

"Através dos tempos, todo setor e quarteirão da cidade assume algo do caráter e das qualidades de seus habitantes. Cada parte da cidade tomada em separado inevitavelmente se cobre com os sentimentos peculiares à sua população. Como efeito disso, o que a princípio era simples expressão geográfica converte-se

\footnotetext{
23 "Ordem moral” é uma expressão utilizada por Park no artigo de 1915 sem a definição do conceito no seu texto. De acordo com o contexto acadêmico do autor e do artigo, cremos que "ordem moral" quer designar algo como um ordenamento social e cultural de indivíduos que se agruparam de acordo com seus hábitos cotidianos. Claro que nosso objetivo aqui não é atribuir uma definição clara a essa expressão, mas somente esclarecer que não se trata de um julgamento de valor do autor.
} 
em uma vizinhança, isto é, uma localidade com sentimentos, tradições e uma história sua" (idem, p.34).

Em última instância, toda cidade pode ser tomada como um conjunto de áreas naturais formadas por vizinhanças. "Na organização social e política da cidade, ela [a vizinhança] é a menor unidade local” (idem, p.35). A própria presença da vizinhança é um exemplo da interação entre a organização física e a ordem moral dos habitantes na cidade, evidenciando a existência de processos tipicamente urbanos. A organização econômica também é contemplada por Park, e participa da alocação das áreas naturais. Em 1921, ao expor a teoria ecológica, Park diz que a organização econômica advém do processo ecológico de competição pelos meios de sobrevivência, gerando a divisão do trabalho (Eufrásio, 1999): “A organização econômica da sociedade é um efeito da livre competição; é uma organização ecológica" (Park 1921 in Eufrásio 1999).

Ainda sobre as partes da cidade, é interessante destacar a idéia apresentada por Park na quarta parte do texto sobre as "regiões morais", que seriam as áreas da cidade onde os indivíduos de gostos e predileções parecidos se encontram para se divertir e conviver. Não são áreas constituídas de residências, mas caracterizadas pelas atividades ali desenvolvidas (jogos de carta, boates, cinemas, etc):

“(...) na organização que a vida da cidade espontaneamente assume, se manifesta uma disposição da população para se segregar, não meramente de acordo com seus interesses, mas de acordo com seus gostos e temperamentos. A distribuição da população resultante deve ser provavelmente muito diferente daquela trazida por interesses ocupacionais ou condições econômicas" (Park 1915 in Eufrásio, 1999, p.55).

Ao nosso ver, essa é uma idéia que pode ser associada à de "localizações urbanas de idosos" que veremos adiante, pois são também locais eleitos pelos idosos para lazer e sociabilidade.

Ainda assim, a idéia de estrutura urbana não está desenvolvida nesse artigo de Park como uma teoria; esta tarefa será realizada por Ernest Burgess em 1922, depois de formular a teoria ecológica junto com Park em 1921. 


\subsubsection{A vertente ecológica}

Ernest Burgess realizou seu doutorado em 1916 na Universidade de Chicago, e depois de lecionar brevemente em outras universidades retorna à Chicago como professor de sociologia ao lado de Park. No curso introdutório da disciplina de Sociologia, os dois professores ensinavam a teoria que iam construindo à medida que, junto com seus alunos, executavam o programa de investigação proposto por Park. Devido a grande demanda e sucesso da disciplina, decidiram publicar em livro as aulas que proferiam organizadas didaticamente para que se transformasse numa espécie de manual. Então, em 1921, é publicado Introduction to the Science of Sociology, obra na qual aparece, formulada pela primeira vez, a teoria de ecologia humana. Segundo os autores, essa é a perspectiva que daria conta de explicar os processos que constituem a sociedade e, conseqüentemente, a cidade. Embora, segundo Eufrásio (1999), a veia ecológica já se fizesse notar num artigo de Park de 1918, somente nessa obra de 1921 é que a definição de um enfoque ecológico viria a dar substrato para a teoria de estrutura urbana de Burgess.

Examinando o período entre 1915 e 1940 Eufrásio (1999), com base no estudo de Quin (1940) apresenta seis concepções de ecologia humana perpassando os estudos sociais daquela época ${ }^{24}$. A mais sofisticada e de acordo com o que Park propôs é aquela que analisa os "aspectos das relações humanas que não envolvem estímulo e respostas mentais ou conscientes diretos", ou seja, os aspectos do processo de competição entre os homens. A competição é o primeiro processo de interação entre os seres vivos, e acontece em qualquer sociedade, desde as vegetais, às animais e humanas. É uma interação "sub-social e impessoal [que] ocorre por intermédio do meio ambiente natural do qual os participantes dependem, de modo que quando uma unidade muda de posição, afeta os outros". Assim, a competição gera uma organização dos homens no espaço, sobre a qual incidem os processos

\footnotetext{
${ }^{24}$ Eufrásio alerta que, infelizmente, a concepção de ecologia humana que ficou mais conhecida é uma distorção da que foi criada por Park, Burgess e McKenzie. Os estudos que se seguiram sobre áreas sociais, comunidades e vizinhanças são os que foram tomados como representativos da ecologia humana, apesar de não possuírem o enfoque principal dos estudos ecológicos: a busca pelos processos de competição que constituem a comunidade estudada: "As monografias sobre a Hobohemia, a Gold Coast, e a Little Sicily, o Ghetto, o Black Belt, as gangs, áreas de vício e delinquiência e outras áreas da sub-áreas da cidade representariam, nesse sentido, estudos de complexos sócio-culturais, e não de estruturas espaciais sub-sociais preconizadas na concepção sofisticada" (Eufrásio, 1999, p.100)
} 
sociais propriamente ditos, ou seja, aqueles que resultam da competição, como as interações de conflito, assimilação e acomodação ${ }^{25}$.

Eufrásio (1999) também examinou os enunciados da obra de Burgess sobre a teoria ecológica, e demonstrou que a organização resultante da interação dos indivíduos com o meio ambiente por meio do processo de competição seria, para Burgess, a essência da organização das áreas naturais na cidade. As áreas naturais, por sua vez, seriam formadas por comunidades e vizinhanças, fazendo com que o estudo das comunidades seja fundamental para caracterizar a cidade. Burgess explica que as comunidades podem ser tomadas sob três aspectos: ecológico, cultural e político. Destes, o que interessa ao estudioso do urbano são os dois primeiros, pois o aspecto político seria uma demarcação utilizada pelos gestores sociais e pelos políticos propriamente ditos.

No tratado de 1921, onde estão as concepções e conceitos utilizados em toda a obra posterior de Park e Burgess, há uma definição do termo "comunidade" e a sua diferença do termo "sociedade". Apesar de naquela época já haver confusão quanto ao uso desses termos, Park e Burgess esclarecem que a comunidade tem raízes geográficas, ou seja, está vinculada a uma área local, apesar de ter, “em abstrato”, as características da sociedade que pertence. A sociedade é o conjunto dos grupos sociais e das comunidades com características em comum. No estudo da cidade interessa abordar a comunidade, pois ela expressa socialmente "a distribuição geográfica dos indivíduos e instituições" de determinada área (Park e Burgess, 1921 in Eufrásio 1999, p.69).

As comunidades ou vizinhanças são formadas por forças ecológicas, culturais e políticas. As forças ecológicas são as que organizam fisicamente o espaço da vizinhança, devido ao processo de competição, resultando na "distribuição e segregação por residência e ocupação" dos indivíduos. As forças culturais agem sobre a organização formada pelas forças ecológicas e geram as diferenças de linguagem, costumes e tradições locais. As forças políticas são as que organizam as instituições públicas (no sentido formal do termo) e o aparelho administrativo da comunidade. Importante salientar que para Burgess as forças

\footnotetext{
25 Segundo Park e Burgess, esses três tipos de interação relacionam os grupos sociais na cidade e dão forma às áreas naturais. São conceitos básicos da ecologia humana que depois foram grandemente apropriados por parte da psicologia social que se desenvolveu nos Estados Unidos a partir dos anos 1950. Não nos cabe aqui explicitá-los, mas recomendamos uma visita à obra de Park e Burgess 1921, onde aparecem pela primeira vez nas ciências sociais.
} 
ecológicas são as principais, pois denotam a organização que dará base para a incidência das outras forças. Foi pelo estudo das forças ecológicas que o autor chegou ao esquema das cinco zonas urbanas concêntricas que explicam o crescimento da cidade.

A teoria de Burgess da estrutura urbana partiu desses princípios ecológicos e da observação de que havia padrões da distribuição das vizinhanças na cidade. Burgess observou que os padrões de organização física e moral da cidade se modificavam à medida que se afastavam do centro, como se os conjuntos de comunidades e vizinhanças formassem zonas urbanas concêntricas, que se sucederiam enquanto a cidade se expandia.

A motivação principal da teoria de Burgess é explicar justamente o processo de crescimento da cidade, e para isso o autor utiliza o conceito de estrutura urbana, uma construção ideal de um esquema de expansão da cidade. Observando os processos que incidiam sobre as áreas naturais de Chicago e de outras cidades do país também em franco desenvolvimento, Burgess concluiu que o crescimento da cidade se dá radialmente, por processos de invasão, expansão e sucessão de uma zona urbana sobre outra, formando zonas urbanas concêntricas a partir do primeiro local de comércio e produção, geralmente o ponto de origem da cidade.

Burgess visualizou uma representação gráfica para essa estrutura urbana, como mostra a figura a seguir: 


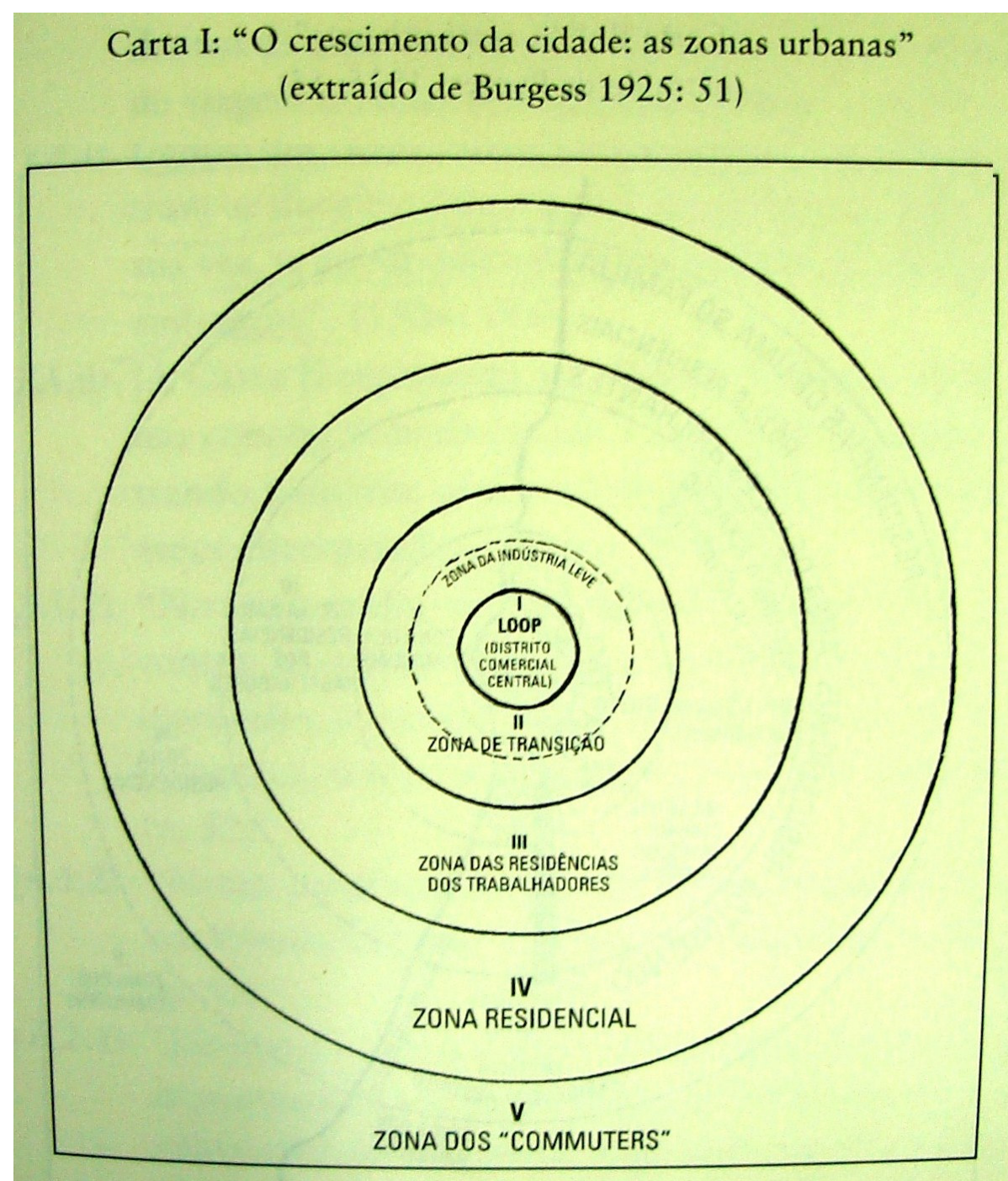

Figura 2: Representação gráfica da estrutura urbana elaborada por Burgess em 1922. Figura extraída de Eufrásio, 1999, p.81.

Nesse esquema de zonas urbanas que se sucedem, o centro é a primeira zona circular, chamado de CBD ou Loop (Central Business District, que significa Distrito Comercial Central). Nessa área está a primeira e maior região de comércio e negócios da cidade, onde estão os arranha céus (no caso de Chicago), as lojas de departamento, as estações ferroviárias, enfim, a zona que concentra os serviços e atividades econômicas tipicamente urbanas. 
Segue-se a esse primeiro círculo uma segunda zona, chamada de "Zona de Transição", pois é uma zona residencial, contígua ao centro, que também contém comércio e fábricas. Com o passar do tempo, e com a expansão do CBD, a Zona de Transição vai se tornando cada vez mais comercial, favorecendo a desorganização social ${ }^{26}$ e a deterioração, predominando geralmente casas pobres e cortiços que abrigam os imigrantes de primeira de fixação, que precisam morar perto do trabalho (as fábricas de manufatura). Comunidades étnicas compõem essa zona, como a Chinatown (chineses), a Little Sicily (italianos), o Ghetto (judeus), no caso de Chicago. No caso da cidade de São Paulo, nosso exemplo mais próximo de Chicago, seriam os bairros do Bexiga e da Mooca (concentrando imigração italiana), o bairro da Liberdade (de imigração japonesa, chinesa e coreana) e o bairro do Bom Retiro (concentrando primeiramente imigração judaica, depois coreana e recentemente boliviana).

Imediatamente após está a "Zona da Casa dos Trabalhadores Independentes", na qual habitam os imigrantes que ascenderam social e economicamente, desejam habitações melhores e mais distantes da sujeira e do barulho da Zona de Transição, mas ainda não podem ficar muito longe do local de trabalho. Afastando-se mais ainda, sempre radialmente, encontramos a "Zona das Melhores Residências", formada por edifícios de apartamentos de "uma só família", ao contrário dos prédios de cortiço da Zona de Transição que abrigam várias famílias num só domicílio. Nessa zona - que recebe aqueles que estavam na zona anterior e ascenderam ainda mais economicamente - já se encontram bancos, salões de beleza e restaurantes um pouco mais requintados, formando pequenos centros comerciais de importância regional, que Burgess chamou de "loops satélites". Já são um começo do processo de descentralização centralizada, que veremos adiante.

Por último, já nos limites territoriais da cidade, a quinta e última, a Zona dos Commuters, onde estão as mansões das grandes famílias ricas matricêntricas, que tem bons carros, podendo trabalhar nas localizações centrais da cidade e habitar distante delas, na

\footnotetext{
${ }^{26}$ O processo de desorganização social é citado por Burgess, mas não é caracterizado, como em The Polish Peasant, de Thomas e Znanieck, obra na qual esse conceito apareceu pela primeira vez. Mas Burgess quer apontar a idéia de que na Zona de Transição o indivíduo, geralmente um imigrante recém chegado, está sujeito a viver um conflito moral entre a sua cultura e a que ele está encontrando, com "senso de perda pessoal e conflito mental". Isso faria com que naquela área fossem mais freqüentes crimes e delinqüência, atentando contra a ordem social vigente, e, ao mesmo tempo, propondo uma reorganização social. Ver Thomas e Znaniecki, 2004.
} 
tranquiilidade das áreas verdes. Normalmente a Zona dos Commuters já se encontra fora dos limites administrativos da cidade central, mas está perto das vias de acesso ${ }^{27}$.

Assim, cada zona interna tende a "estender sua área pela invasão da zona próxima externa”, ocasionando a expansão da estrutura urbana (Burgess, 1924 in Pierson, 1970). Mesmo que não haja mais território na metrópole, a expansão adentrará cidades vizinhas, tanto para dar lugar para a Zona dos Commuters, como para abrigar aqueles que não acompanharam a valorização econômica das residências internas. De certa forma, podemos considerar que Burgess indica que a última zona é a que dá a direção da expansão, ao ser seguida pelas outras. Essa vocação direcionadora da classe ${ }^{28}$ de alta renda (que é quem ocupa a Zona dos Commuters) será recuperada e enfatizada por Hoyt, como veremos adiante.

O padrão zonal da expansão urbana pode ser distorcido por outros dois fatores que influenciam o crescimento: barreiras naturais do terreno, que podem ser topográficas e hidrográficas, e barreiras artificiais, como o arruamento e a direção das redes de transportes. A existência de lagos, rios, e mar influenciam o direcionamento da expansão, pois atraem as classes mais ricas, que desejam aproveitar a paisagem privilegiada. Um rio pode dividir a cidade ao meio e tornam um dos lados mais desenvolvido que o outro (o que abriga o centro). Da mesma forma, quando a cidade cresce sobre um terreno montanhoso, as áreas mais altas, geralmente mais isentas de riscos físicos e biológicos como inundações e epidemias é que são as procuradas pelos grupos mais abastados, e não necessariamente as mais afastadas. Esse é o caso dos Jardins e da Avenida Paulista em São Paulo, por exemplo.

\footnotetext{
${ }^{27}$ Burgess não se atém aos limites políticos municipais. Seu esquema de expansão abrange a área urbana na qual é possível deslocar-se diariamente, e, por isso, atribui aos transportes a delimitação da área urbana: “A área metropolitana pode ser considerada como incluindo o território urbano que é fisicamente contíguo, porém está agora sendo definida pelos meios de transporte que possibilitam a um homem de negócios viver num subúrbio de Chicago e trabalhar no loop e sua esposa fazer compras na loja Marshall Field’s e assistir à ópera no Auditorium". (Burgess, 1922-25, p.50 in Eufrásio, 1999, p.85).

${ }^{28}$ Para acompanhar a trajetória das classes sociais no espaço da cidade é preciso considerá-las, inicialmente, como grupos de indivíduos com renda e lugar semelhantes no processo de produção capitalista, pois nas estatísticas oficiais disponíveis, estão classificados somente em números de salários mínimos. Nessa dissertação concentraremos nossa atenção, seguindo a linha de Hoyt, nas localizações residenciais da classe de alta renda, que define o vetor de expansão da cidade. Posteriormente, numa análise da situação recente da estrutura urbana mais direcionada a caracterizar as localizações urbanas de idosos, observaremos aspectos sociais, simbólicos e culturais na distribuição da população pela cidade. Então, poderemos analisar as classes sociais definindo-as não só pela renda, mas também por suas práticas sociais, pelo espaço que conseguem ocupar, pelo seu tipo de circulação e uso da cidade.
} 
Em Santos este fator quase não atua, pois a cidade está numa planície e as únicas áreas altas são os morros, que ao contrário, foram evitados, por serem áreas mal servidas de infraestrutura $^{29}$.

Burgess (1929) discute o arruamento em forma de tabuleiro de xadrez, que é o de Chicago e o da maioria das cidades americanas e em grande parte também é o caso de Santos. Nesse tipo de arruamento os locais privilegiados são os que estão nas direções dos pontos cardeais, nos catetos dos ângulos retos, e não os que ficam entre eles (as bissetrizes noroeste, sudoeste, etc), pois a tendência dos meios de transportes é circular nas "artérias" principais (retas norte, sul, leste e oeste). Essas avenidas geralmente são as que fornecem a direção para o crescimento do bairro. Nos locais onde há cruzamentos de meios de transporte, ou de grandes vias de circulação, formam-se, geralmente pequenos centros, como é hoje o Largo da Batata, em São Paulo.

O planejamento das ruas e a disposição das barreiras naturais podem, juntos, produzir locais desfavoráveis para residência, como é o caso dos morros em Santos e das extremidades opostas às áreas residenciais de alta renda. Essas terras são comumente habitadas por pessoas muito pobres e abrigam a indústria pesada.

Burgess, com o conceito de estrutura urbana, visava também fazer considerações acerca da expansão como processo, como diz o título da segunda seção de seu artigo. Assim, a estrutura urbana não é uma fotografia ou um mapeamento da cidade, mas uma construção ideal que tenta explicar os processos que fazem a cidade organizar suas comunidades e a se expandir. O primeiro deles é chamado de invasão, que consiste na chegada de um contingente populacional numa zona urbana provocando a sua invasão na outra zona mais exterior. Burgess referia-se, naquela época, às grandes massas de imigrantes chegando à cidade e fixando-se concentrada e primeiramente na zona central ${ }^{30}$. À medida

\footnotetext{
${ }^{29}$ Nos últimos anos os morros têm recebido equipamentos urbanos, saneamento básico, escolas e postos de saúde, mas ainda continuam aquém das outras áreas da cidade, e ainda oferecem riscos de desabamento. A exceção fica por conta dos morros Nova Cintra e Santa Terezinha, de terras mais planas, abrigando inclusive mansões e um condomínio fechado.

${ }^{30}$ É preciso lembrar o momento histórico em que esta teoria foi concebida, que foi o começo do século XX, época, nos Estados Unidos, de construção das grandes cidades, de superprodução (período anterior à crise de 29) e chegada de muitos imigrantes europeus que fugiam da Primeira Guerra Mundial. Nesse sentido, essa teoria é melhor aplicada para explicar a formação das cidades nessa mesma época no Brasil. No caso de Santos, entendemos que a aplicação é válida, pois nesta mesma época a cidade crescia com os avanços da produção do café,
} 
que ascendem economicamente e começam a adquirir outros costumes, mudam-se para a zona urbana seguinte, ocupando as habitações deixadas pelos grupos que residiam ali anteriormente e que também se mudaram para a zona seguinte ${ }^{31}$. Esse processo de sucessão de grupos populacionais em zonas urbanas impulsiona a classe da zona mais externa a procurar outros terrenos, pois o local onde estavam já começava a adquirir características indesejadas. As zonas vão, assim, crescendo e mudando de terreno. Onde antes era considerada área essencialmente residencial, com o passar do tempo, passa a ser comercial e central. Vale a pena a reprodução de um trecho no qual Burgess descreve esse movimento, que pode ser facilmente atribuído à caracterização da expansão de Santos na época da intensificação do comércio do café, como veremos no capítulo seguinte.

"A invasão da cidade [pelos imigrantes] tem o efeito de uma onda de maré inundando primeiro as colônias de imigrantes, os portos de primeira entrada, desalojando milhares de habitantes que refluem para a zona seguinte e assim por diante, até que o ímpeto da onda tenha gasto sua força na última zona urbana; o efeito no total é o de acelerar a expansão, acelerar a indústria, acelerar o processo de 'lumpenização' na área da deterioração [zona de transição]” (Burgess, 1922-25 in Eufrásio, 1999, p.85)

O processo geral de expansão contém em si os processos de concentração $e$ desconcentração. O processo de concentração é caracterizado pela tendência de convergência do transporte das áreas locais e externas para o centro, e o segundo ressalta o desenvolvimento dos subcentros comerciais "que atraem freqüentadores de toda a cidade ao oferecer atrações mais 'elegantes’ em zonas afastadas do centro" (Burgess, 1929, p.6). Em 1922 Burgess apenas chama atenção para a existência desses processos, que, juntos, chamou de "descentralização centralizada".

Burgess adota a metáfora do "organismo" que Park também utiliza para conceber a cidade. Sua preocupação é também com o metabolismo da cidade, ou seja, com o nível de organização e desorganização social da cidade. Uma medida para esse metabolismo social é

recebendo também grande contingente de imigrantes e passando pelos mesmos processos sociais apontados por Burgess, conforme explicaremos nas páginas seguintes.

${ }^{31}$ O bairro do Bom Retiro, em São Paulo é um exemplo: inicialmente foi ocupado por judeus, depois coreanos e recentemente bolivianos, como mostra a pesquisa de Marcela Rufato exposta no Encontro do Centro de Estudos Rurais e Urbanos (CERU) em 2004. 
a mobilidade, ou seja, a freqüência dos deslocamentos dos indivíduos pelas áreas naturais da cidade. Quanto maior a mobilidade, mais impessoal tornam-se seus contatos e suas relações, favorecendo a desorganização social, com o desprendimento do indivíduo da sua vizinhança. Em certa medida, a desorganização social é natural e tolerável, pois é sinal de transformação para outra organização social (reorganização social). Por outro lado, se a expansão da cidade for rápida demais, a desorganização pode se dar em excesso e causar "o aumento excessivo de doenças, prostituição, desordens, insanidade e suicídio" (Burgess, 1922-25 in Pierson, 1970, p 364). A intenção de Burgess, nessa parte de seu artigo, é captar a caracterização das áreas da cidade pelo comportamento dos seus habitantes, e a mobilidade social é um termômetro do nível de desorganização social da comunidade observada.

A concepção de estrutura urbana de Burgess contém um conjunto de elementos de análise da cidade, e chega a prever processos de produção de localizações urbanas ao falar dos loop satélites. De certa forma, as considerações que veremos a seguir sobre os estudos de Hoyt $(1939,1964)$ já estão sugeridas em Burgess. Apesar de a perspectiva ecológica ser seu ponto de partida, o objetivo de Burgess era a expansão e a organização da cidade e não os processos sub-sociais. Burgess sabia que para cumprir seu objetivo isso era necessário mergulhar necessariamente pela ordenação econômica da cidade e esclarece: “a diferenciação em grupos econômicos e culturais naturais dá forma e caráter à cidade, pois a segregação oferece ao grupo e aos indivíduos que o compõe um lugar e um papel na organização total da vida da cidade" (Burgess, 1922-25, p.361 in Pierson 1970). Por outro lado, a perspectiva ecológica não se furtava a esse fator, considerando a organização econômica na divisão do trabalho como uma consequiência do processo de competição advindo da luta pela sobrevivência.

A nosso ver é inegável que há elementos dessa teoria que persistem nos estudos urbanos atuais, e que, se a sua representação gráfica já não serve para explicar fielmente a estrutura urbana das grandes cidades atuais, cheias de centralidades, explica pelo menos as primeiras etapas de sua formação. 


\subsubsection{A concepção sócio-econômica}

Cronologicamente, é a segunda matriz teórica da Escola de Chicago para explicar a organização territorial e social da cidade. Foi consolidada por Homer Hoyt, em 1939, ao realizar um estudo para o Departamento Federal de Habitação dos Estados Unidos. Analisando os padrões de uso do solo de algumas cidades americanas, Hoyt adaptou os melhores estudos daquela época e criou um esquema próprio de interpretação e esquematização da expansão das cidades. O esquema baseia-se na proposição de Burgess, mas se afasta da explicação ecológica ao caracterizar as vizinhanças apenas por níveis sócioeconômicos. No parecer de Eufrásio (1999), é um esquema que "manifestadamente se vale de uma interpretação baseada em dados e conceitos econômicos e sociais e na clara pressuposição de processos, relações e fatores de natureza sócio-econômica para a explicação da estrutura espacial da cidade” (Eufrásio, 1999: 209). Além da ausência do compromisso com a teoria ecológica, essa concepção diferencia-se por privilegiar o estudo dos padrões de uso de solo residenciais, com foco no movimento das áreas residenciais de alta renda. Hoyt não desprezou o estudo dos outros tipos de uso do solo, mas acreditava que "na consideração do crescimento da cidade, o movimento das áreas de altas rendas é, num certo sentido, o mais importante, porque tende a arrastar consigo o crescimento da cidade inteira na mesma direção" (ibidem). Dessa forma, o autor prefere apresentar "a estrutura de áreas sociais da cidade através do critério de caracterização dos grupos sociais que as habitam pelas suas categorias de renda" (idem, p.210), e não por suas características morais, comportamentais ou étnicas.

A compreensão do processo de expansão e, a nosso ver, de organização social dos territórios da cidade, é facilitada por uma representação gráfica desse movimento, no qual a cidade é considerada um círculo e as várias vizinhanças situando-se em setores que se deslocam em um vetor que parte do centro desse círculo às extremidades. Assim como o de Burgess, esse esquema de estrutura urbana também é um tipo ideal "que tenta dar conta de processos espaciais de crescimento urbano". Mas ao invés de zonas concêntricas ocupando toda a coroa de um círculo e representando "áreas naturais" - como quer a teoria ecológica Hoyt delimita setores dentro dessas coroas de círculo, que correspondem às vizinhanças, definidas, por sua vez, por categorias de renda. 


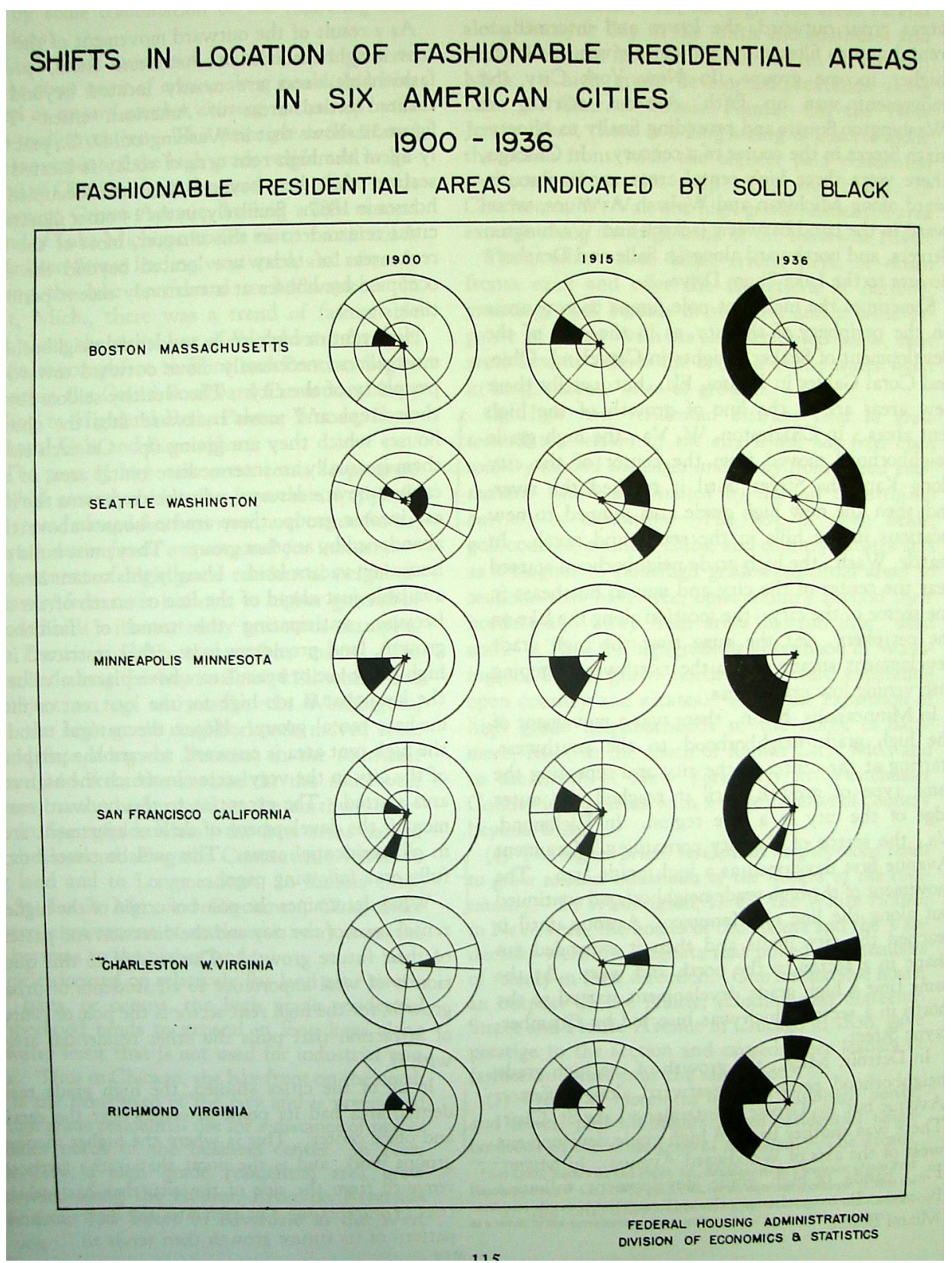

Figura 3: Representações gráficas das estruturas urbanas de Boston, Seattle, Minneapolis, San Francisco, Charleston e Richmond, com a indicação do deslocamento das áreas residenciais de alta renda (setores pretos). Figura extraída de Hoyt, 1939, p.115.

Observa, então, como ao longo do tempo as vizinhanças vão se deslocando para outra área, sempre em direção à localização onde estão as residências de alta renda, que por sua vez, vão se afastando em fuga da deterioração física e social e em busca dos melhores sítios geográficos. Dessa forma, as categorias de renda vão ficando mais baixas à medida que nos aproximamos do centro. 
A expansão da cidade é, assim, direcionada pela classe de alta renda, pois é no rastro dela que vão as outras áreas residenciais, assim como as lojas e os serviços de preços mais elevados. Mas essa aproximação se dá na trajetória de um vetor, e não radialmente. Em primeiro lugar, porque a própria área residencial de alta renda, ao movimentar-se, acompanha uma via de trânsito rápido; apesar de se afastar do centro, não abre mão de um acesso rápido a ele. Em segundo, porque as classes que conseguem aproximar-se da classe de alta renda não estão em número populacional suficiente para ocupar toda a coroa do círculo, ocupando também apenas um setor, beneficiando-se das instalações abandonadas.

Mantendo a direção da expansão, as classes de alta renda comumente só podem se movimentar para frente, e não para os lados, pois geralmente ao lado já se instala uma classe de renda intermediária, e assim, os terrenos disponíveis acabam sendo os que ficam à frente. As classes médias não se adiantam em ocupá-los porque são terrenos antecipadamente reservados por incorporações imobiliárias, que cobram o preço que só a classe de alta renda pode pagar (Hoyt, 1939 in Eufrásio, 1999:217). Outro fator que pode restringir a ocupação das terras laterais são as barreiras naturais, as quais já mencionamos.

A origem da área de alta renda é, portanto, a origem da trajetória de expansão da cidade. Examinando a formação da área urbana através de recursos variados, como fotos antigas e entrevistas com velhos moradores, Hoyt descobre que a primeira área de ocupação da classe rica foi próxima ao primeiro núcleo de negócios que surgiu. A partir dessa descoberta, e da observação do movimento das áreas de alta renda, Hoyt "postula", como diz Eufrásio, as seguintes tendências ${ }^{32}$ : estabelecidas em direção a outro núcleo de construções existentes ou em direção a centros comerciais";

2) "A zona das áreas de rendas altas tende a ir para terrenos mais altos, livres de inundações, (...) longe das indústrias instaladas perto do centro";

\footnotetext{
32 "Tendências" é mesmo o termo utilizado por Hoyt, que não se arrisca a definir nenhuma direção de expansão, mas apenas a indicar tendências, respeitando a limitação típico-ideal do conceito de estrutura urbana. Burgess, o primeiro a apontar a direção de crescimento de uma cidade também afirmava apenas "tendências", e não leis. Em todo o nosso estudo, seguiremos essa orientação, investigando tendências, como também fez Villaça (1998) na sua obra sobre as metrópoles brasileiras, como veremos mais adiante.
} 
3) "A zona de residências de alta renda tende a ir para setores de campo livre", [sem barreira para expansão posterior];

4) “As vizinhanças residenciais de mais altos preços tendem a crescer em direção às casas dos líderes da comunidade";

5) "As tendências de movimentos de edifícios de escritórios, bancos e lojas arrastam vizinhanças residenciais de altos preços na mesma direção geral";

6) "As áreas residenciais de alto padrão tendem a seguir vias de transporte rápido";

7) “A direção do crescimento das áreas de altas rendas continua a mesma por muitos anos";

8) "Apartamentos de luxo tendem a se estabelecer próximos do centro em áreas mais antigas";

9) “Os empresários de imóveis podem desviar a direção do crescimento residencial de alto padrão" (Hoyt, 1939 in Eufrásio, 1999: p. 221).

Segundo Hoyt, as vizinhanças têm um ciclo de vida, e tendem a se deteriorar pela invasão de "forças de diferenciação", como o comércio, a depreciação física das edificações, e o envelhecimento dos próprios moradores. Junto a isso, há a perda de status provocada pela competição constante de novas áreas, muitas vezes "criadas" pelas incorporações imobiliárias. Contra essa deterioração é que há o movimento das classes de alta renda para longe do centro.

Mas como mostrou a oitava tendência, algumas áreas centrais são mantidas como local de residência de alta renda. É uma exceção que deve ser considerada segundo Firey (1945), que estudou as áreas residenciais de alta renda no centro de Boston, argumentando a necessidade de novas variáveis de análise que descrevam certos processos ecológicos da cidade não explicáveis por razões estritamente econômicas. Em resposta a estudos de sua época - que se diziam ecológicos, mas que enfatizavam o fator econômico como impulso para a movimentação das áreas residenciais na cidade - o autor apresenta dados que sugerem duas alterações principais nas premissas básicas da ecologia humana, tal como se praticava 
na sua época ${ }^{33}$. A primeira é que o espaço seria visto não apenas como um impeditivo ao estabelecimento de certas atividades locais, mas também como uma propriedade, um símbolo de certos valores culturais que estariam associados a sua área espacial, e a segunda, é que as atividades locais não são agentes econômicos apenas, mas também "nutrem sentimentos que podem influenciar significativamente os processos locais" (Firey, 1945:141, tradução minha).

Firey testa essas hipóteses no centro de Boston, apontando certos padrões de uso de solo que foram herdados do passado e persistiram às mudanças econômicas. "Tal persistência de padrões espaciais só pode ser entendida nos termos e valores, que são símbolos dos grupos que ali habitam" (Firey, 1945:140). Três tipos de padrões persistentes seriam observáveis: 1) classe alta residindo no centro (Beacon Hill), 2) lugares "sagrados", como o "Boston Common" e "The Colonial Burying Grounds" e 3) a vizinhança de italianos de classe baixa conhecida como "Fim do Norte" (North End). Nesses usos do solo há processos locais que, na opinião de Firey, desafiam uma análise estritamente econômica.

Beacon Hill, de acordo com a descrição de Firey, é uma comunidade com identidade própria, muito querida por seus moradores, que fazem questão de expressar isso. A história do bairro parece ter sido importante para marcar esses sentimentos estéticos, históricos e familiares, etc, que adquiriram expressão espacial em Beacon Hill. Eles podem gerar processos locais retensivos, atrativos ou de residência, de acordo com as observações de Firey, que atentou para a influência desses sentimentos em cada atividade local. $\mathrm{O}$ autor tabulou onde moravam as famílias em Boston de acordo com a classe social de cada uma, descobrindo três concentrações espaciais de famílias de alta renda no centro, sendo uma delas Beacon Hill, e cinco concentrações suburbanas. De 1890 a 1950 decrescem as famílias nas duas concentrações centrais e aumentam as suburbanas a partir de 1905. A tendência de Beacon Hill manter-se destoa das outras.

\footnotetext{
${ }^{33}$ A explicação da "vertente ecológica" da seção 1 desse capítulo corresponde ao período em que foi iniciada, de 1915 até 1940, que é o período analisado por Eufrásio (1999). Dos anos 1940 em diante os estudos urbanos mesclam as duas concepções (ecológica e sócio-econômica de estrutura urbana), e muito do que constituiu a teoria ecológica foi se perdendo. Infelizmente, esses estudos posteriores nem sempre se atêm aos princípios teóricos ecológicos ou sócio-econômicos e são tomados como representativos da "Escola de Chicago", como se ela fosse homogênea.
} 
A história de Beacon Hill mostra uma comunidade atuante que consegue, através de ações articuladas, revitalizar o bairro, usando, para isso, estratégias de planejamento urbano $^{34}$. Firey considera determinante o fator sentimental para explicar porque aquela classe continua ali, ao invés de utilizar seu poder econômico para residir em outros sítios melhores na cidade.

Podemos também considerar o artigo de Firey como um diálogo com o estudo de Hoyt (1939) e com outros estudos que seguiram tal concepção. No entanto, em 1964 Hoyt revisa seu estudo e publica o artigo "Recent Distortions of Classical Models of Urban Structure" ${ }^{35}$, no qual aponta que importantes mudanças na sociedade americana refletiramse na estrutura urbana alterando muitas de suas tendências e padrões.

Hoyt analisa novamente as principais proposições de Burgess em 1922-25 e 1929 acerca do padrão de estruturação urbana das cidades industriais americanas dos anos 20 e compara com o que ele observa nos anos 60, assinalando as mudanças que ocorreram em cada zona delimitada por Burgess. Aponta também quais tendências que ele sugeriu em 1939 que se confirmaram e outras que surgiram depois, embora o autor tome a concepção de estrutura urbana de Burgess como o paradigma clássico.

De maneira geral, as mudanças demonstradas zona por zona revelam a preponderância de dois "fatores dinâmicos" principais na estruturação das cidades americanas: a popularização do automóvel e o aumento da população. Assim, vemos que na Zona Um, (“CBD” (Central Business District), as lojas começam a lucrar menos, perdendo a concorrência para shoppings situados nas fímbrias da cidade, com grandes estacionamentos e bastante espaço. Os escritórios passam a acompanhar cada vez mais a localização de residência das classes de alta renda, ou também acompanham os centros de serviços que surgem nos subúrbios. Os tradicionais hotéis do centro perdem clientela para aqueles mais modernos, que se instalam perto das estradas e oferecem amplos

\footnotetext{
${ }^{34}$ Em São Paulo, Heitor Frúgoli (2000) estudou associações da classe de alta renda que tentam controlar o planejamento urbano e as ações públicas para preservar a área que ocupa, com a associação Viva o Centro, e a Associação Paulista Viva. O autor não atribui isso a fatores sentimentais, mas na sua obra podemos observar também movimentos de resistência da classe de alta renda à deterioração, que, nesses casos, é equivalente ao aumento do comércio e da circulação de classes pobres na área.

${ }^{35}$ Ver Hoyt, 1971.
} 
estacionamentos. A Zona Dois, "Zona de Transição", perde a tendência de concentrar fábricas, que passam a preferir a zona rural para instalar suas grandes plantas fordistas de produção. Abandonada, a Zona de Transição sofre reformas urbanas, nem sempre bem sucedidas, e a deterioração social se acentua com a chegada de famílias negras, que vão, aos poucos, ocupando também as casas deixadas para trás pelos trabalhadores da Zona Três, a “Zona das Residências dos Trabalhadores”. Para Hoyt a Zona da Casa dos Trabalhadores Independentes é a próxima zona a ser alvo de "limpezas urbanas" ("to be cleared away").

Já a quarta, a Zona das Melhores Residências, foi a que manteve o seu padrão, com as mesmas tendências residenciais de concentrar famílias de classe média alta.

A Zona dos Commuters, área de residências de alta renda, continuou com padrão setorial de ocupação ao invés de circular, como Hoyt já havia assinalado em 1939, mas agora têm mais espaço para se movimentar, pois com a melhoria das vias para carros, ou seja, com a construção de anéis viários, o setor não se mantém mais na direção de apenas uma via de transito rápido.

A melhoria do acesso à metrópole aumenta a população das cidades periféricas, aliás, outra nova tendência observada por Hoyt em 1964: o ritmo de crescimento maior nas cidades periféricas do que na metrópole. Mas a intensidade desse fenômeno nos Estados Unidos é incomparável, segundo o autor: nem nas grandes capitais latino-americanas Hoyt havia observado tantos automóveis como nas cidades industriais americanas, embora o autor tenha indicado que há aumento contínuo do número de automóveis e da população na América Latina.

Em suma, nos anos 1960 o aumento da população é uma tendência mundial e influencia fortemente a estruturação das cidades. Nos Estados Unidos, observou-se também aumento da renda per capita e estabilidade da moeda, possibilitando muitas famílias adquirirem imóveis e carros com financiamentos de bancos e companhias de seguro. A popularização do automóvel é decisiva para definir a localização das áreas residenciais, pois reduz o tempo de deslocamento, tornando desnecessário, para famílias de classe média e alta renda, residir próximas ao trabalho e ao centro de compras. Esses consumidores preferem áreas residenciais próximas a locais bem estruturados e de fácil acesso, como os espaçosos shoppings e complexos de serviço construídos nos subúrbios, com amplos estacionamentos. 
Começaria aqui o fenômeno de decadência do centro, observado em quase todas as grandes cidades. O centro comercial perde clientela e as indústrias, que não são mais as fábricas dos anos 20, passam a preferir a zona rural, onde têm mais espaço. Os trabalhadores não precisam mais conviver com a desorganização social da zona de transição, e tendem a residir também cada vez mais distantes do centro. As zonas seguintes, cada vez mais centrais com o aumento da cidade, abrigam aqueles que até então não tinham acesso às edificações residenciais deixadas pelos trabalhadores: as famílias negras e "pessoas brancas sozinhas". Assim, embora o crescimento populacional seja maior nos subúrbios do que na cidade central, a tendência de liderança da classe de alta renda se mantém, pois ela ainda ocupa os sítios mais cobiçados, que agora são os mais próximos dos anéis viários, dos complexos de serviços, e distantes da deterioração e desorganização social, cada vez mais acentuada do esquecido centro.

Segundo Hoyt essas tendências ainda não se verificavam nas cidades latino americanas. Naquele momento elas cresciam em população, mas tinham alta inflação e baixa renda per capita, dificultando o acesso ao automóvel e a novas moradias. Porém, poucos anos depois, pudemos ver que, de modo mais agressivo e desordenado, as cidades brasileiras experimentaram um explosivo crescimento, urbanizando o país.

O que faz dessa teoria adequada para o caso de Santos, e bem utilizada por Villaça para as metrópoles brasileiras, é que ela enumera fatores essenciais à estruturação de cidades capitalistas, ou seja, qualquer cidade que tenha classes proprietárias, de alta renda e classes trabalhadoras, pobres, com necessidades de deslocamento e disputando espaço entre si, pode ser analisada à luz dessas formulações, sempre considerando as peculiaridades de cada espaço, como já dizia Burgess em 1929. A introdução do automóvel muda significativamente a estruturação das cidades, reduzindo a importância da proximidade com o centro para a classe média e de alta renda. Considerar o aumento populacional e o acesso aos bens como fatores importantes de organização das classes sociais no espaço é essencial para explicar as cidades latino-americanas, habitadas por trabalhadores, consumidores, desempregados, todos disputando, sob condições desiguais, o melhor espaço para residir e transitar. 
Por outro lado, o conceito de estrutura urbana, nascido da corrente ecológica, iniciou essa reflexão, dando o caminho para que Hoyt chegasse a essas conclusões. Como já assinalamos, o esquema pioneiro proposto por Burgess 1922-25 não deve ser descartado, pois é o que explica a formação da primeira configuração estrutural de uma cidade.

Ao categorizar as vizinhanças por renda e perceber que há padrões de movimentação residencial desses grupos sócio-econômicos, Hoyt afirma que o espaço urbano está ocupado por classes sociais, ainda que não haja, no seu texto, a definição de um conceito de "classe social". A teoria de Hoyt parece ter sido dotada por Flávio Villaça (1998) para estudar as metrópoles brasileiras, porque, ao utilizar os "setores", e não "zonas concêntricas", permite apreender o desenvolvimento urbano de uma sociedade com grande desigualdade social, que tem pouca população com alta renda, uma comprimida classe média e uma grande classe pobre sendo deixada para trás. Como já vimos, pensar conceitualmente a cidade como organizada em uma estrutura urbana pode ajudar a entender a sua reprodução social e como ela própria é o reflexo dos processos que estruturam a sociedade. Santos deve ser analisada sob esse mesmo prisma. Passemos, então, ao exame da perspectiva marxista de estudos urbanos.

\subsection{Estudos urbanos marxistas ${ }^{36}$}

É possível encontrar uma exposição comentada e crítica dos principais temas do debate marxista acerca da produção do espaço urbano na obra de Mark Gottdiener, $A$ produção social do espaço urbano (1997 [1985]). Nesse trabalho, o objetivo do autor é demonstrar que a ciência urbana de sua época (anos 1980) não conseguia explicar certos fenômenos como a desconcentração de grandes centros industriais que ocorria nos EUA; partindo dessa problemática para elaborar uma revisão das principais teorias urbanas. A conclusão é a de que as teorias de Castells e Lefebvre se complementam e, se reformuladas, podem dar contar da complexidade dos fenômenos sócio espaciais. Tomamos as obras de

\footnotetext{
${ }^{36}$ É imensa a bibliografia marxista sobre as cidades, e em diversos campos das ciências sociais (geografia, sociologia, urbanismo, economia, para citar alguns) e de nenhuma maneira pretendemos apresentá-la inteiramente aqui ou selecionar as obras mais marcantes. Nesse momento do nosso texto interessa-nos apresentar as obras mais significativas ao nosso ver que ajudam a pensar conceitualmente o enfoque do espaço material da vida cotidiana, onde vivem seus habitantes, o que chamamos, junto com Villaça (1998) de espaço intra-urbano.
} 
Manuel Castells, A Questão Urbana (2000 [1968]) e Henri Lefebrve, The Production of Social Space (1991 [1975]) como dois marcos nos estudos sociológicos do espaço socialmente construído na sociedade moderna. Estes autores, e os estudos derivados dessas duas vertentes possibilitam a construção de nosso objeto e da nossa hipótese, e a contextualização da noção de espaço intra-urbano.

O ponto de partida de ambos é o mesmo: "o espaço é um produto material de uma dada formação social" (Gottdiener, 1997: 120), mas os autores diferem quanto à maneira de abordar essa dimensão social do espaço. Para Castells a teoria do espaço urbano deve ser uma especificação da teoria geral da organização da estrutura social, já que o espaço não é fruto apenas de avanço tecnológicos e de aumentos demográficos, mas também de um processo histórico de formação, o que confere a cada qual a sua especificidade. Já Lefebvre eleva o espaço à condição de categoria explicativa e busca uma teoria marxista do espaço.

Castells enfatiza a estrutura econômica e rejeita o urbano como unidade ideológica (a pretexto de resposta às teorias da Escola de Chicago) e a estrutura política como fatores explicativos, já que não são mais os problemas políticos, mas os econômicos que organizam o espaço social, concordando com o althusserianismo ${ }^{37}$. Assim, divide a estrutura econômica do urbano em dois elementos: os meios de produção e a força de trabalho. Na sua busca de um objeto urbano de análise, Castells adota a força de trabalho como foco para explicar os processos de estruturação do espaço urbano. Os meios de produção não seriam um bom enfoque porque conduziriam a uma análise dos problemas regionais, já que o espaço de produção, graças aos avanços tecnológicos do processo de produção, ultrapassa delimitações urbanas (Castells, 2000: 55). A força de trabalho, como parâmetro de análise, confere à unidade urbana uma força de estruturação do espaço ao se articular com o conjunto das estruturas sociais. Nas suas palavras: "nas sociedades capitalistas avançadas, o processo que estrutura o espaço é o que concerne à reprodução simples e ampliada da força de trabalho" (2000:336).

Com base nessas premissas, Castells consegue elevar o urbano ao status de unidade espacial de reprodução da força de trabalho. Ou seja, para Castells "não existe teoria

\footnotetext{
${ }^{37}$ Perspectiva teórica proveniente da obra de Louis Althusser, comentador da obra de Marx que concebe a sociedade como um conjunto de três estruturas que formariam a estrutura social: a ideológica, a política e a econômica, que em última instância, determina as duas anteriores. Ver Althusser, (1983).
} 
específica do espaço, mas simplesmente desdobramento e especificação da teoria da estrutura social, para prestar conta das características de uma forma social particular, o espaço, e de sua articulação a outras formas e processos dados historicamente" (2000: 192, grifos do autor) e a melhor maneira de analisar a estrutura urbana que daí advém é pelo estudo dos movimentos da força de trabalho, já que é ela que realiza o consumo do espaço.

Propor o urbano como um elemento que deve ser incluído na análise das outras estruturas sociais é um mérito de Castells que deve ser aproveitado, apesar de não tomarmos a força de trabalho como único elemento fundamental estruturador do espaço. Nossa intenção é justamente analisar outras forças de produção social do espaço além da força de trabalho. Concordando com Villaça (1998), priorizaremos a idéia da força dos movimentos dos consumidores ${ }^{38}$ enquanto fator de produção e re-significação social do espaço.

Diferente de Castells e da economia política marxista, Lefebvre deseja realizar uma teoria marxista centrada no próprio espaço, que o observe não somente no plano estrutural das relações de produção, mas também como um produto destas mesmas relações de produção. Resumidamente, vemos que para este autor o espaço é também objeto de consumo e o seu próprio design espacial é convertido em mercadoria. Para Lefebvre, a importância do espaço é conquistada pela dialética entre valor de uso e valor de troca, que produz tanto um espaço social de usos quanto um espaço abstrato de expropriação. Ou seja, o espaço é tomado, ao mesmo tempo, como uma abstração concreta, um meio de ações sociais e um produto dessas ações. Assim como o valor de troca, o espaço só pode ser apreendido dialeticamente, e é, portanto, "ao mesmo tempo objeto material, produto, o meio destas relações sociais e o reprodutor dos objetos materiais e relações sociais" (Gottdiener1997: 133).

Tendo em vista os pressupostos e teorias expostas durante todo o capítulo podemos, agora, examinar a noção de espaço intra-urbano, necessária para compreender o conceito de localização intra-urbana (ou simplesmente localização urbana), chave para a construção do nosso objeto de estudo.

\footnotetext{
${ }^{38}$ Quando Castells refere-se à força de trabalho como estruturadora do espaço urbano está considerando-a no seu lado consumidor dos bens coletivos urbanos, no entanto, ao utilizar o termo "movimento de consumidores" queremos ressaltar que há consumidores de bens coletivos que não são mais força de trabalho, como os idosos, por exemplo.
} 


\subsection{Teoria da localização intra-urbana de Villaça.}

Espaço Intra-urbano no Brasil, de Flávio Villaça, retoma nos estudos brasileiros, os estudos de estrutura urbana das cidades. É, ao nosso ver, a obra que melhor apreende o contexto intelectual do nosso objeto de estudo e a que juntamente com as perspectivas que vimos, contém os conceitos que permitem a construção de nossa problemática. $\mathrm{O}$ autor retoma alguns dos principais estudos da escola de Chicago, como os de Burgess (1922-25) sobre o crescimento das cidades, e depois os de Hoyt $(1939,1964)$ - cujas premissas consideramos como base para o estudo dos processos sócio-espaciais que constituem a cidade - sem deixar de considerar as conclusões dos estudos acerca do espaço urbano enquanto expressão espacial do sistema capitalista, trazendo essas teorias para o estudo das cidades brasileiras.

Revisando a bibliografia dos estudos urbanos brasileiros, Villaça percebe que há uma confusão de termos para denominar o mesmo objeto de estudo e que provoca uma mistura de muitos enfoques. O autor observa, por exemplo, como análises que utilizam o termo "espaço urbano", na verdade, incidem sobre a dinâmica do espaço regional, e não do que é urbano. Para designar o que é essencialmente urbano, o autor cunha o termo "espaço intra-urbano", já que o termo "espaço urbano" está desgastado por maus usos. Villaça considera o urbano como uma dimensão particular de análise, embora reconheça o espaço socialmente construído como resultado de uma articulação entre as estruturas políticas, econômicas e sociais, como afirmou Castells (2000). Merece, portanto, uma denominação diferenciada da atribuída ao espaço regional.

O espaço intra-urbano é o espaço da cidade; é nele que acontece a vida urbana cotidiana; é a própria expressão territorial da estrutura urbana. Seus territórios, organizados por ruas, avenidas, praças, marcos físicos naturais, etc, ganham sentidos e significados conforme são ocupados de acordo com os fluxos de consumo ${ }^{39}$ e produção, e pelo comportamento da população que os visita e utiliza.

\footnotetext{
${ }^{39}$ Villaça cita este termo no seu estudo, mas não o conceitua. Nesta pesquisa entendemos que o autor referiase aos efeitos dos movimentos da população no espaço intra-urbano enquanto consumidora. Neste mesmo sentido, o utilizaremos para nos referir aos movimentos dos idosos no espaço intra-urbano de Santos enquanto consumidores, seja de produtos, de serviços ou do próprio espaço, como na praia.
} 
O espaço intra-urbano tem dois tipos de valor de uso: o valor dos objetos em si (um prédio, uma praça, um grande terreno, ruas, calçadas, asfalto) e o seu valor de localização, isto é, os eu valor em termos de acessibilidade e centralidade. Para Villaça, a localização de um espaço intra-urbano é também um de seus valores de uso e enquanto tal um atributo único do espaço intra-urbano. Os espaço significativos pela sua localização são chamados de localizações intra-urbanas. Descobrir como se organiza o espaço intra-urbano é, em grande parte, indagar sobre como são produzidas as suas localizações urbanas (o mesmo que "localizações intra-urbanas"). Assim, em Espaço Intra-Urbano no Brasil, o objetivo de Villaça é "entender as localizações intra-urbanas, a constituição e os movimentos de espaço intra-urbano das metrópoles brasileiras" (1998:11).

As localizações urbanas são pontos significativos no espaço intra-urbano pela sua acessibilidade e pela sua relação com outros pontos. É um valor de uso produzido também pela urbanização, além do valor de uso dos objetos em si. A nosso ver, as localizações urbanas são também fundamentalmente referenciais sociais no território da cidade, pois os grupos sociais que passam ou frequientam esses lugares, caracteriza-os socialmente. Esse aspecto de como se produz a localização intra-urbana será desenvolvido no quarto capítulo deste trabalho.

São os deslocamentos de pessoas que importam à estruturação do espaço intraurbano, e não os de mercadorias ou de populações como força de trabalho (que estruturam o espaço regional, por meio da migração). Esses deslocamentos de pessoas podem ter finalidades variadas: a busca de serviços, de produtos, a ida ao trabalho ou a busca de seus pares: a ida a um encontro entre amigos, conhecidos, etc... À medida que combinam mais atrativos, as localizações urbanas são freqüentemente utilizadas e se fortalecem como marcos referenciais para medir o valor de uso de localização de outros territórios também. Por exemplo: um terreno que fica próximo à Praça da Independência, em Santos será muito valorizado economicamente, pois está próximo de uma das áreas de maior circulação de consumidores de classe média. A Praça da Independência é, portanto, uma localização intraurbana comercial. Assim, a localização é o valor de uso de um espaço intra-urbano de estar acessível e de combinar fluxos diversos de consumo e de produção, segundo Villaça (1998). 
As localizações definem as paisagens da cidade e refletem o resultado do jogo entre os processos econômicos, políticos ou culturais que movimentam e desenham a estrutura urbana. Quanto mais freqüentada, mais a localização se afirma no espaço intra-urbano tornando-se um ponto de referência em relação a outros espaços, qualificando-os também quanto à acessibilidade. Elas definem o perto e o longe numa cidade; ou seja, conferem centralidade. A acessibilidade a determinados locais de trabalho ou de consumo é um dos fatores principais de organização das classes sociais no espaço da cidade, de forma que produzir localizações intra-urbanas é também organizar social e economicamente a população no espaço - aspecto que examinaremos adiante.

Se nosso objetivo é estudar transformações que acontecem na cidade, provocadas por uma população idosa que se faz cada vez mais presente e participante, é, também na sua participação nas localizações urbanas que devemos nos debruçar. Por isso, é no espaço intra-urbano que se situa nossa problemática; nesta abordagem podemos mostrar como um grupo populacional pode marcar referências sócio-territoriais numa cidade.

No entanto, para descobrir os pontos de maior frequiência que funcionam como de referência para classificar os lugares da cidade (e classificar também as pessoas que as freqüentam, como sugeriu Park (1976 [1915]) de uma maneira, e Milton Santos (1987) de outra), é preciso examinar a estrutura urbana santista, ou seja, como estão organizadas as classes sociais no espaço intra-urbano da cidade, quais são os locais mais acessíveis e cobiçados, e, daí sim, onde e como são produzidas as localizações intra-urbanas atuais. Nessa análise temos em vista encontrar a participação dos idosos santistas, tanto daqueles que se encaixam no perfil da terceira idade, quanto daqueles que não gozam de autonomia física ou financeira.

Os conceitos de estrutura urbana e a teoria de localizações intra-urbanas de Villaça (1998) serão utilizados, por todo o nosso trabalho de identificar uma estrutura urbana em Santos e situar dentro dessa estruturação o envelhecimento populacional, para então analisar a presença da população idosa no espaço intra-urbano e a produção de localizações intraurbanas. Assim, no capítulo a seguir, o objetivo será examinar como se formou a base da estrutura urbana atual, ou seja, como ocorreu a produção do tecido urbano santista. 


\section{Capítulo 3: A Formação de Santos}

A formação do espaço urbano de Santos e região foi estudada largamente. Há um conjunto considerável de trabalhos que abordam esse tema, sobretudo quanto à expansão urbana que ocorreu no último quartel do século XIX, quando aconteceram as principais obras de infra-estrutura da cidade e do porto. Há obras clássicas da literatura santista que documentam as origens e o desenvolvimento da cidade, assim como teses de doutorado em diversas áreas (Urbanismo, História Social, Demografia) e estudos demandados pela própria municipalidade, como o primeiro projeto de saneamento elaborado por Estevan Fuertes, a Planta de Santos elaborada por Saturnino de Brito, os Planos Diretores de 1968, 1975 e 1998 além de estudos para planos diretores que não foram sancionados, como os Sumários de Dados de julho e novembro de 1992. E há o estudo pioneiro do Departamento de Geografia da Universidade de São Paulo, que divulgou o nome da região metropolitana: "Baixada Santista". Juntamente com nossas observações de campo, será o conjunto desses trabalhos a nossa base para examinar, em linhas gerais ${ }^{40}$, como se formou a estrutura urbana atual que rege o espaço intra-urbano santista.

\subsection{Do período colonial aos primeiros "tempos modernos".}

Santos foi um dos primeiros núcleos urbanos do Brasil Colônia, pois possuía um amplo estuário com livre comunicação para o oceano e, ao mesmo tempo, um sítio urbano mais resguardado, com melhor acesso para o planalto paulista. Esses aspectos geográficos fizeram com que, já em 1546, a Vila de Santos suplantasse a Vila de São Vicente (inaugurada em 1532), tornando-se o porto preferido para importação de manufaturas. Brás Cubas, donatário daquelas terras, percebeu as vantagens daquela da localização geográfica em relação à Vila de Martim Afonso e investiu em seu desenvolvimento, chamando a primeira Santa Casa do Brasil a se instalar lá. Além disso, acreditava-se que as terras da Vila de Santos eram mais propícias à lavoura e ao plantio da cana, e três engenhos foram instalados. No entanto, logo esses negócios arrefeceram, com a concorrência nordestina no

\footnotetext{
${ }^{40}$ Não temos a pretensão de demonstrar e analisar a estrutura urbana de Santos, sendo este um trabalho que por si só merece uma dissertação. Nesse capítulo trata-se apenas de situar o espaço intra-urbano no qual está a população idosa e compreender o fenômeno do envelhecimento populacional dentro dos processos que constituem a cidade.
} 
plantio da cana de açúcar. E Santos, de solo úmido, com chuvas constantes, mais distante do continente europeu do que o Nordeste, caiu em marasmo por muitos anos, ficando com crescimento populacional e urbano estagnado, como explica Araújo Filho (1965):

"Santos até fins do século XVII pouco ou quase nada evoluíra do que fora nos meados do quinhentismo. Os limites da área urbana circunscreviam-se ao que hoje chamamos ‘coração’ da cidade, sua área comercial” (Araújo Filho, 1965, p.27).

Esse pequeno aglomerado urbano foi a "primeira Santos", uma cidade colonial de ruas estreitas, em nada parecida com a estrutura urbana que se constituiria depois das reformas urbanas impulsionadas pela pujança do café:

"Para abrigar uma população de 1625 habitantes, Santos possuía 13 vias públicas, que incluíam as ruas, dois becos e duas travessas" (Andrade, 1989, p.40)

"Durante aproximadamente 300 anos Santos foi uma vila, cujo espaço físico compreendia uma área que ia do Outeiro de Santa Catarina Á igreja e Convento de Santo Antônio do Valongo, que podia ser percorrida a pé em meia hora. Do lado do Campo, isto é, na direção dos morros, não ultrapassava a Rua do Rosário [hoje Avenida João Pessoa]" (idem, p. 19). 


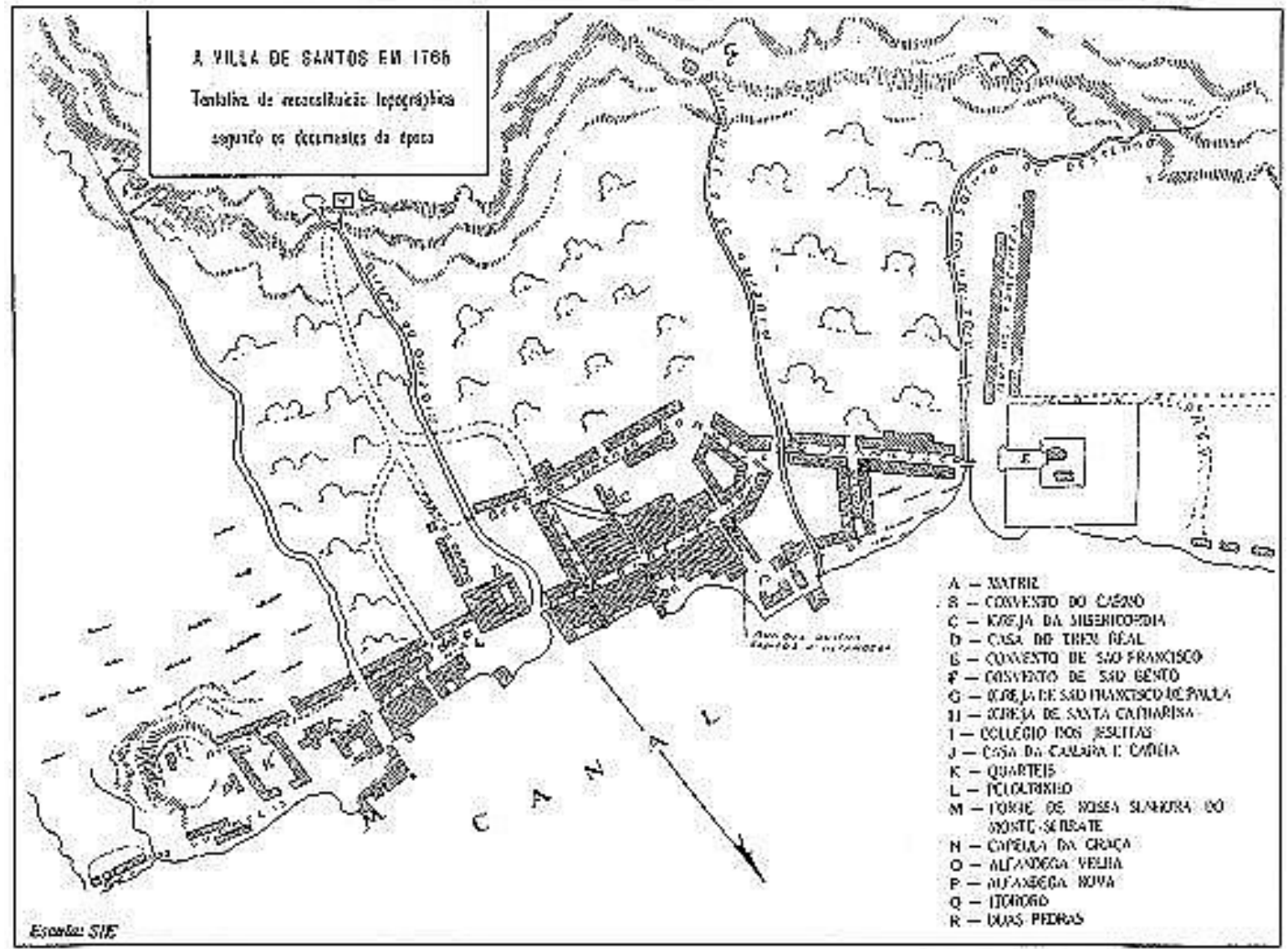

Figura 4: “A vila de Santos em 1765”, trabalho de reconstituição da Vila de Santos feito por Benedito Calixto, a partir de documentos do século XVIII. Na parte inferior da figura está uma pequena porção da orla norte da Ilha de São Vicente onde nasceu o porto. Imagem extraída do Jornal Eletrônico O Novo Milênio em http://www.novomilenio.inf.br, que digitalizou a imagem de SOUSA, Alberto. Os Andradas, Vol. I, Typographia Piratininga, São Paulo/SP, 1922.

A direção da expansão urbana de Santos foi, inicialmente, junto ao mar pela parte noroeste da ilha, por onde passavam os lavradores que, para irem à Vila de São Vicente, desembarcavam em Santos para depois seguirem pelo Velho Caminho de São Vicente (também conhecido como Caminho do Mar, que é entre onde está hoje o bairro do Marapé e a avenida Nossa Senhora de Fátima).

No início do século XIX, a ocupação urbana privilegiou os terrenos à beira-mar, pois eram os melhores para o comércio de importação de manufaturas e a tímida exportação de açúcar. Contudo, quando o café começou a ser exportado pelas fazendas do interior paulista e mineiro, a cidade passou a crescer em direção ao planalto. Nesses tempos em que o café era transportado por mulas, formou-se o núcleo urbano de Cubatão, parada de 
viagem para São Paulo. Essa direção mudou quando começou a funcionar, em 1867, a ferrovia São Paulo Railway, que eliminava a parada das tropas muares em Cubatão. Desde então, o desenvolvimento de Cubatão diminuiu, nunca mais voltando a ser como antes. Até hoje é uma das áreas mais pobres da Região Metropolitana.

A construção da ferrovia em 1867 marcou definitivamente o crescimento de Santos e a organização do seu espaço intra-urbano, fazendo com que a produção do café pudesse ser transportada em maior escala, o que permitiu o aumento da demanda de trabalho no porto. Santos cresceu: em 1900, de 5000 prédios passou a ter, em 1913, 88.947 prédios e 10.578 habitações na zona urbana e rural (ASSECOB, 1984). O tempo de viagem entre Santos e São Paulo era diminuído consideravelmente, permitindo que as pessoas retornassem a São Paulo no mesmo dia. As elites podiam, então, manter negócios em Santos e morar em São Paulo, fugindo das epidemias constantes devido às inundações e às más condições de higiene:

"Era famoso o trem dos comissários que partindo de São Paulo às 10:30h chegava em Santos e retornava à capital às 16:00h. Igualmente transportava os imigrantes e nacionais que se dirigiam rapidamente para diferentes pontos da província/estado, fugindo muitas vezes das precárias condições locais”.(Lanna, 1996:56).

Nessa época as elites ainda não buscavam se fixar nas praias. O costume europeu do banho de mar que atraiu as elites cariocas (Villaça, 1998) era ainda impensável naquelas condições:

"Entre 1890 e 1900, as epidemias ceifaram em Santos cerca de 50\% dos habitantes [em 1892, quando morreram 4173 pessoas]. Morria-se com incrível facilidade, parecendo vulgar à população render-se ao cerco fatal da febre amarela, varíola, peste bubônica, impaludismo, disenteria, febre tifóide e outras doenças" (Rodrigues, 1980, p.43).

"Quando chegavam os navios estrangeiros, ao porto de Santos, para carregarem o café e outras mercadorias, as companhias armadoras retiravam suas tripulações e mandavam-nas para lugares distantes da cidade. Na Ilha de Palmas, ficava a tripulação de um determinado navio; outra ia para Ribeirão Pires, outros 
para a área continental de Santos e só voltavam para o navio quando estava pronto para zarpar. E quem trabalhava? Portugueses, espanhóis, italianos, brasileiros e negros libertados pela Lei Áurea - que precisavam de empregos. Os que mais facilmente contraíam a doença eram os estrangeiros. Santos tornou-se o "porto maldito". Havia anúncios das companhias armadoras, na Europa, que avisavam que seus navios não paravam no Porto de Santos, como quem diz: 'pode embarcar tranqüilo"” (Andrade, 2005) ${ }^{41}$

Santos tornou-se um local propício para epidemias, pois com seu clima úmido e quente, e terras alagadiças e planas (dificultando o escoamento das águas das chuvas), não possuía nenhum sistema de saneamento ou de esgoto, e o lixo era depositado nos ribeirões que cortavam a cidade, a céu aberto. O primeiro surto de febre amarela ocorreu antes do início da imigração, em 1844, mas depois, principalmente no auge da imigração na década de 1870, a cidade viveu seus piores dias, pois recebia alto volume de população e não tinha habitações suficientes, produzindo situações insalubres de sobrevivência. De acordo com o recenseamento de 1872, Gitahy (1992) informa que havia 9.191 habitantes alojados em 1392 prédios. Destes habitantes, 1577 eram estrangeiros. Já em 1890 a cidade contava com 13.012, embora em 1886 tivesse 15.605. As epidemias aumentavam o número de mortes, mas muitos eram os que chegavam, pois em 1896 “os inspetores sanitários estimavam que a população local girasse em torno dos 35.000 habitantes. Para abrigar tanta gente, cortiços nasciam de casarões de outrora, e outros cortiços ficavam cada vez mais lotados, constituindo-se, assim "num novo segmento da economia, alavancando um mercado imobiliário rentista na área urbana" (Carriço, 2006, p.05).

\footnotetext{
${ }^{41}$ A mesma autora realizou uma tese de doutorado na qual examinou exaustivamente as epidemias que assolaram a cidade, as quais chamou de "peste negra santista". Ver Andrade, (1989).
} 


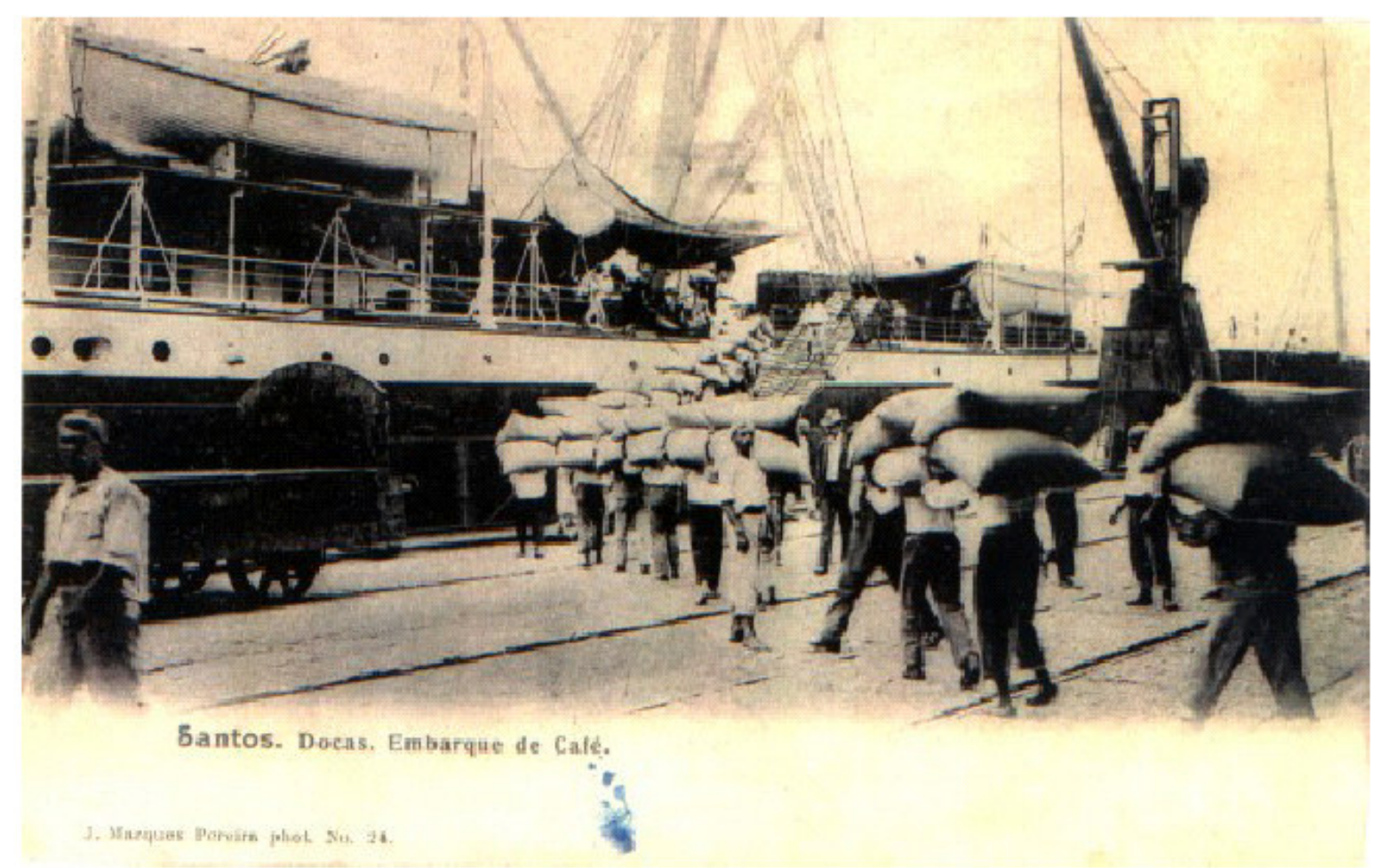

Figura 5: "Santos, Docas. Embarque de Café". Cartão Postal de 1905, produzido por José Marques Pereira, fotógrafo da cidade. Trabalhadores carregando sacas de café. Sobre o fotógrafo, ver a análise de Lobo, (2004) de onde foi extraída essa imagem. Fonte: Gerodetti, Coleção Particular apud Lobo, 2004, p.114.

As epidemias atrapalhavam a entrada dos imigrantes que vinham do sul da Europa, força de trabalho barata, necessária para a acumulação de capital agro-exportador e preferida aos escravos por trazerem consigo a civilidade urbana européia ${ }^{42}$. Eram tantas as mortes que "o governo provincial impôs às tripulações quarentena na barra, o que causou enormes prejuízos à economia cafeeira" (Carriço, 2006, p.04). A reforma do porto tornavase necessária, e por isso o governo central concedeu à Companhia Docas de Santos (CDS) - formada pelos empresários brasileiros Cândido Gafrée e Eduardo Palassin Guinle que acumularam bastante capital em uma loja de tecidos no Rio de Janeiro e subempreitando a construção de ferrovias no Nordeste - a operação do porto mediante a sua reforma. Essa decisão não teve o apoio da Câmara Municipal, que defendia os interesses dos comerciantes

\footnotetext{
${ }^{42}$ Sobre esse assunto, ver Merric \& Graham, (1981) e Naxara, (1998).
} 
locais que seriam prejudicados, pois a construção do cais derrubaria os trapiches ${ }^{43}$. No entanto, a reforma foi realizada e a concessão ampliada por mais 90 anos pelo governo central. São famosos e bastante registrados os conflitos entre a CDS e a Associação Comercial de Santos, que não ficaram somente nas contendas judiciais, mas também em atos de violência apoiados pela população - também oprimida com a destruição concomitante dos cortiços, no episódio conhecido como "Guerra dos Trapiches",44. Mas nem assim a CDS se intimidou e com a retaguarda do posicionamento do governo central, o primeiro trecho do cais foi construído, tornando-se a primeira obra de saneamento básico de Santos, já que eliminando os trapiches, limpava-se uma grande área de depósito de lixo a céu aberto próxima às residências da cidade.

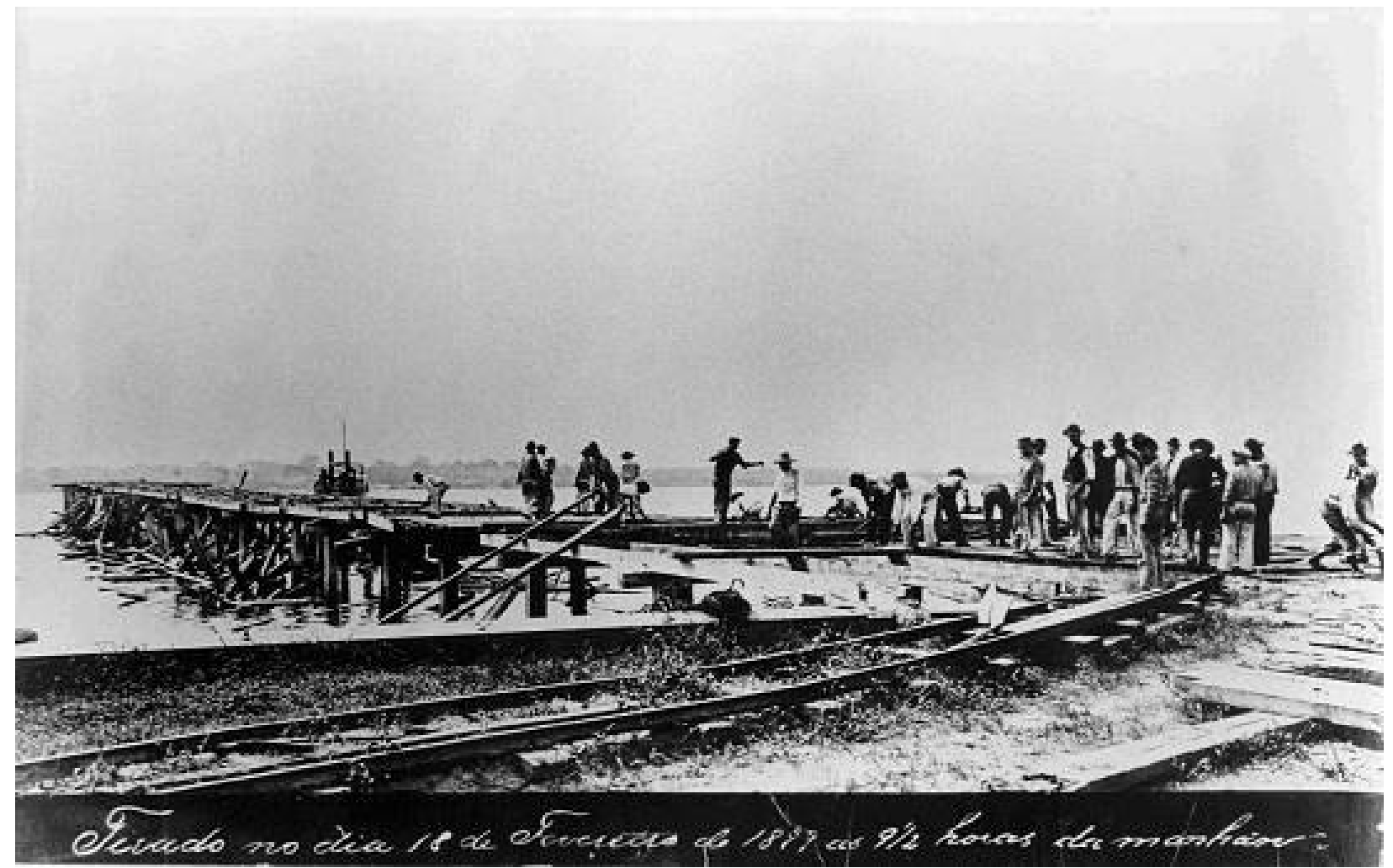

Figura 6: Foto da demolição do trapiche Brasil, em 1897. Extraído do Jornal Eletrônico Novo Milênio (http://www.novomilenio.inf.br) em 05/05/2006.

\footnotetext{
${ }^{43}$ Trapiches são pequenos armazéns com pontes de madeira que avançavam pelo mar até os navios. Serviam para desembarcar e guardar a mercadoria recém chegada e embarcar a que ia partir. Eram de propriedade de comerciantes locais. $\mathrm{O}$ cais substituiu os trapiches acabando com esse negócio local.

${ }^{44}$ Sobre as lutas da população santista contra as decisões externas dos governos provincial e central, ver Lanna, (1996) e Gitahy, (1992)
} 
Mas se o porto já tinha um cais e uma ferrovia, faltava ainda acabar com a má reputação gerada pelas epidemias. Em 1892, mesmo ano da construção do cais, e do maior número de mortos pela febre amarela (4173 pessoas) a municipalidade contrata Estevan Fuertes, engenheiro porto-riquenho que seguia o urbanismo norte-americano. Fuertes elaborou um plano essencialmente preocupado com a higiene e o saneamento da cidade, mas por ser muito caro para o capital municipal, não foi implantado inteiramente. Somente quando as epidemias ameaçaram chegar às cidades do interior paulista é que esforços efetivos são realizados pelo Estado em conjunto com o Município (Carriço, 2006). Assim, o Governo do Estado, através das suas Secretaria da Agricultura e Secretaria do Interior implantou a Comissão Sanitária de Santos, chefiada pelo médico Guilherme Álvaro, com o poder de fechar cortiços e de tomar todas as medidas necessárias para isso. Começava a destruição violenta dos cortiços, com as "ordens científicas” da comissão.

Em 1896 o Estado criou a Comissão de Saneamento e passou a se responsabilizar pelo oferecimento de serviços de água e esgotos, os quais, até então, eram alvos de reclamações por parte da população, por serem caros e ineficientes. Em suma, nas palavras de Carriço, "O agravamento das epidemias, que passaram a obstaculizar o comércio cafeeiro, tornou necessário controlar o processo de produção do espaço e a vida cotidiana no sítio urbano, por meio da legislação e de intervenções no meio físico" (Carriço, 2006, p.7).

Contudo, era preciso solucionar também, além do problema das epidemias, o da habitação. A escassez imobiliária já era um velho problema da cidade. Desde 1873, quando Santos era refúgio dos escravos que vinham das fazendas do interior de São Paulo, "a falta de moradias em Santos era problema", conforme cita Andrade (1989, p.92), do relatório do Dr. Ignácio Wallace Gama Cochrane, presidente da Câmara. A mesma autora informa que em 1889 a cidade tinha duas mil casas e 15.600 habitantes. De acordo com Gitahy (1992) em 1893 já tinha 30.000 e 3.234 casas, e em 1896, já contava com 35.000 habitantes e apenas 3.600 casas, uma média de 9,7 moradores por domicílio, que muitas vezes, tinha um só cômodo; e não havia mais porções de terras naquela região onde construir. Porém, os empreendedores imobiliários espreitavam outro mercado: pressionavam a Câmara para que logo fossem realizadas as obras que permitiriam a venda e o loteamento das terras desejadas 
pela classe de média e de alta renda da cidade que já deslocavam sua área residencial para longe da sujeira e das classes pobres:

"O grupo mais abastado seguia a velha tradição paulista de morar em chácaras - ficavam afastadas da cidade suja, poluída, perigosa pela presença de uma grande população, vulnerável a freqüentes epidemias" (Andrade, 1989, p.160)

"Em 1896 a Câmara de Santos contrata José Brant de Carvalho para chefiar o Setor de Obras Públicas e elaborar um plano de expansão para a cidade. Enquanto os estudos e propostas de Fuertes não eram implementadas pelo estado, a municipalidade sinalizava claramente que não estava disposta a esperar pelo saneamento para estender a malha urbana. As obras das Avenidas Conselheiro Nébias e Ana Costa já estavam avançadas, ao passo que o serviço de bondes, tracionados por animais, constituía-se em grande estímulo aos loteamentos que começavam a ser executados na área externa ao núcleo central. Não por acaso, proprietários de terrenos e loteadores faziam-se representar na Câmara, tendo como maior liderança Belmiro Ribeiro. Desta forma, havia claro interesse comum entre concessionários dos serviços de bondes e loteadores, que em alguns casos confundiam-se na mesma figura" (Carriço, 2006, p.10).

Carriço (2006) argumenta que a reforma urbana de Santos era interesse não só do Governo Central, e depois do Estado de São Paulo - representando o capital cafeeiro como também dos empresários locais, seja de imóveis ou de transportes. Ao nosso ver, nessa informação está também o fato de haver uma classe de alta renda da cidade que necessitava de área residencial e já se mobilizava para conseguir as condições desejadas. Afinal, se o Estado precisava do porto funcionando plenamente e os empresários das terras saneadas para vender, havia uma elite que iria comprar essas terras. Além disso, apesar das políticas higienistas atuarem pesadamente na "limpeza social" do Paquetá, as terras cobiçadas eram as da orla. Ou seja, as preferências residenciais da elite é que deram a direção da expansão, como Hoyt teorizou em 1939. 


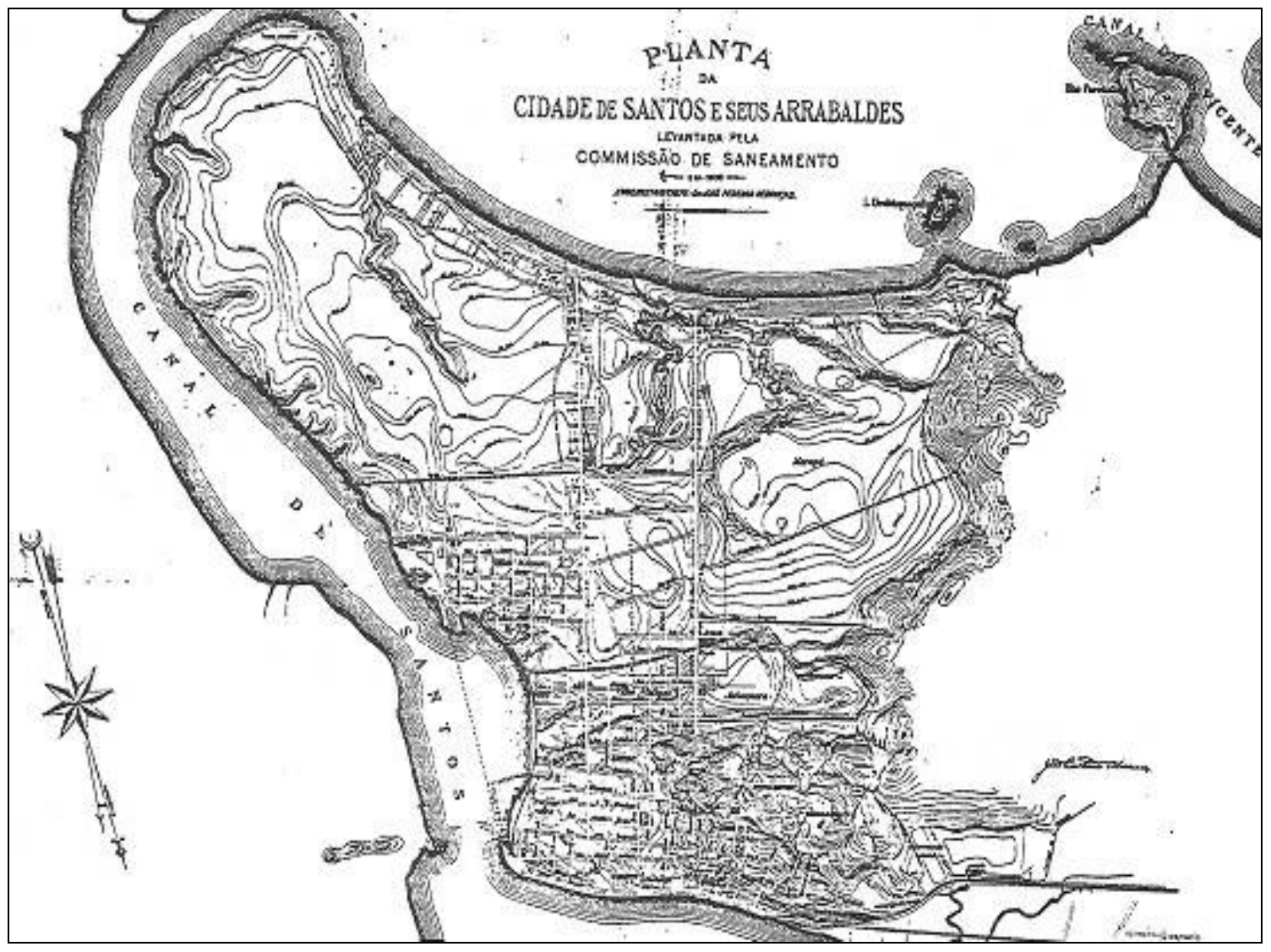

Figura 7: Na parte superior da planta se vê a orla marítima sul. Na parte inferior está o lado norte, no qual se iniciou a urbanização e dali já despontavam as avenidas Ana Costa e Conselheiro Nébias, os vetores que ligariam o centro à praia. Figura da Planta de 1903 de Santos, editada pela Comissão de Saneamento chefiada por José Rebouças, extraída do sítio Jornal Eletrônico Novo Milênio em http://www.novomilenio.inf.br em 05/06/2005.

Em 1897, a Câmara já dispunha de um projeto elaborado de urbanização das terras intermediárias à orla. O projeto era inspirado em cidades americanas, com desenho reticulado e monótono, sem respeitar a hidrografia e a topografia e nem "a ação humana", segundo o comentário de Saturnino de Brito (Andrade, 1989 e Carriço, 2006). Mesmo tecnicamente inferior, o projeto atendia aos interesses dos empresários de transportes e dos loteadores e foi aprovado imediatamente pela Câmara Municipal, assim como foi sancionado o seu Código de Posturas.

Para Carriço (2002), que analisou a legislação urbanística de Santos, desde esse Código de Posturas de 1897 que a segregação residencial dos pobres foi oficializada. As suas exigências ao construir aumentavam o custo da edificação, dificultando o acesso à 
moradia pelas classes trabalhadoras, principalmente ao permitir construir somente em lugar designado pela Câmara, como apontou Lanna, (1996).

Em 1898, é extinta a comissão de Saneamento e criada a repartição de Águas e Esgotos do Estado de São Paulo, chefiada pelo engenheiro baiano Theodoro Sampaio. A atuação desse engenheiro foi responsável pelo arrefecimento das epidemias ao implantar rede de esgotos na área central com ajuda financeira do governo central e fazer a manutenção da rede que já havia antes. Em 1901, após um "tumultuado" processo de concorrência pública para a implantação da rede de esgotos, a Comissão de Saneamento foi reconstituída, e em 1902, quando o mandato do governo estadual foi para Bernardino de Campos, José Rebouças assumiu a coordenação da Comissão. As obras continuaram, porém, com a utilização de manilhas de concreto armado, solução cara e refutada por Theodoro Sampaio, que volta para a Bahia. O governador Bernardino de Campos estava apoiado por empresas importadoras e fabricantes desse produto, utilizado em grandes proporções por Rebouças em obras pontuais, sem um planejamento global para a cidade (Costa, 2001 apud Carriço, 2006).

O novo Presidente do Estado de São Paulo, Jorge Tibiriçá, diante dos altos custos e da demora da conclusão da obra de Rebouças, contrata como chefe da Comissão de Saneamento, em 1905, Saturnino de Brito, engenheiro fluminense que já havia trabalhado no saneamento de Belo Horizonte.

Saturnino de Brito, que já vinha estudando Santos desde 1898 (Andrade, 1989 e Carriço, 2006) apresentou um planejamento completo para a cidade que sugeria a rede de esgoto em separado da rede de drenagem, com a utilização das manilhas de concreto em sua construção, e um plano urbanístico. Nesse período as obras ganharam ritmo acelerado, assim como a ocupação da porção leste da Ilha de São Vicente.

No entanto, as propostas de Brito eram abrangentes "demais":

“(...) não se limitaram ao desenho apresentado, prevendo também, a aprovação de uma nova legislação urbanística, que em muitos aspectos feria os interesses dos proprietários de imóveis, ao procurar facilitar a desapropriação dos terrenos necessários à abertura e ao alargamento de vias, limitando o aproveitamento 
dos terrenos. Esse conflito resultou na ruptura com a Câmara Municipal e com setores da imprensa que defendiam aqueles interesses" (Carriço, 2006, p.15).

Quando a proposta foi enviada para a Comissão de Obras e Viação do Município, foi recusada sua implantação imediata, pois não estaria "tecnicamente adequada", e juridicamente feria o princípio do direito de propriedade. Com base nesses argumentos, a Câmara não aprovou plenamente a proposta de Brito "por motivos técnicos". A planta acabou sendo implementada "com profundas modificações" (Carriço, 2006, p.16). Mesmo assim, tornou, de fato, habitáveis as terras intermediárias entre a orla e o centro.

A forma como foi realizada a reforma urbana santista demonstra que, apesar da necessidade do capital cafeeiro e da CDS em poder contar com o porto no qual haviam antes investido tanto, a classe de alta renda da cidade também agia na mesma direção, interferindo no processo quando lhe interessava. Convergiram os interesses do Governo do Estado de São Paulo em manter o Porto de Santos como saída para a exportação de café, facilitando a sua venda e a chegada da sua força de trabalho (imigrantes), com os interesses da CDS que queria ampliar o cais e a capacidade do Porto para auferir mais lucros e recuperar o dinheiro já investido, e os interesses dos empreendedores imobiliários e da Associação Comercial, esta última, muito ligada ao comércio do café, pois era composta de negociantes locais que ofereciam serviços de corretagem e agenciamento de compradores de café no exterior. O porto deixando de ser o preferido para esse comércio ${ }^{45}$, logo esses negócios se acabariam. E os empreendedores imobiliários, por fim, precisavam de outras terras para continuar ganhando dinheiro com a exploração do solo.

O conjunto de reformas e principalmente o planejamento urbano de Saturnino de Brito trouxeram à cidade não só melhorias infra-estruturais, mas uma nova cidadania, um novo espírito de civilidade urbana na maneira de usufruir a cidade e utilizar o espaço público, a qual é objeto de análise de Lanna (1996), Andrade (1989) e abordada por Gitahy (1992) e Lobo (2004). Lanna (1996, p.80) salienta que embora a visão de Saturnino de Brito fosse a da promoção do acesso à terra para todos, seu plano procurava “disciplinar os comportamentos sociais tanto nos espaços públicos quanto nos espaços privados, através da

\footnotetext{
${ }^{45}$ Outros portos faziam concorrência com o Porto de Santos, como o Porto de São Sebastião e o do Rio de Janeiro, mas o Porto de Santos era o preferido porque possuía boas vias de escoamento da produção (a moderna São Paulo Railway ). Entretanto, as epidemias começavam a torná-lo um lugar a ser evitado.
} 
socialização do sentimento de intimidade e da negação de toda e qualquer promiscuidade, sobretudo através das ações dos higienistas e reformadores sociais".

Essas reformas marcam o início da separação espacial das classes sociais em Santos por meio da segregação residencial. Interessa-nos nessa parte de nosso trabalho, explicitar como esse conjunto de reformas urbanas, além de ampliar a infra-estrutura portuária e urbana e disciplinar e cercear o uso do espaço público, ajudou a delinear uma estrutura urbana, ou seja, uma lógica de crescimento da cidade e de organização das classes sociais no seu espaço, como assinalou Burgess (1922-25, 1929), e depois Hoyt (1939). A construção da ferrovia é o início desse processo, gerando uma configuração da estrutura urbana diferente da que existia na época que o Porto somente exportava açúcar e importava manufaturas, quando a cidade possuía menos de dez mil habitantes.

Essa estrutura urbana está evidenciada na pesquisa de Andrade (1989), embora a autora não utilize o conceito de estrutura urbana. Ao mostrar "o discurso do progresso", a urgência dos santistas em entrar para a modernidade, tanto Andrade (1989) quanto Lanna (1996) nos indicam que havia uma ordem anterior a ser refutada - a estrutura urbana colonial. Os impactos da aceleração do transporte de pessoas e de mercadorias oriundos da ferrovia marcam essa transição para o moderno.

Ao caracterizar a estrutura urbana básica das metrópoles brasileiras, tanto as litorâneas quanto as do interior, Villaça (1998) chama a atenção para atuação das ferrovias e depois das rodovias (ou seja, as vias regionais) na urbanização das cidades brasileiras por oferecerem um eixo de urbanização. Em Santos isso também ocorreu, como relata Lanna nesse trecho:

"Ao seu redor [da ferrovia] apareciam novos lugares de convivência. Os quiosques instalados na estação rapidamente transformaram-se em local de encontro da população. [A ferrovia] alterou o tecido urbano e ao associar-se com o porto definiu esta área da cidade como essencialmente comercial. Daí para frente, as elites foram gradativamente abandonando o Valongo e dirigindo-se para áreas novas na cidade em expansão [primeiramente as terras laterais do Paquetá, e depois as terras marginais às avenidas Ana Costa e Conselheiro Nébias]. Esta região [Valongo] 
consolidou-se como de habitação de trabalhadores ligados ao porto, à ferrovia e aos inúmeros armazéns e depósitos instalados na região" $(1996: 55,56)$.

A ferrovia tornou mais comercial a área central, fazendo com que a população que ia ascendendo economicamente procurasse outras terras mais distantes. É o início do processo de expansão das zonas urbanas, com a Zona Central (Zona 1) invadindo a Zona de Transição (Zona 2), que passa a conviver com as classes de alta renda. Estas, no entanto, logo tratarão de buscar outras terras, seja deixando de residir na cidade, ou transpondo barreiras naturais.

Mas ao invés de uma expansão urbana dada por processos característicos de sucessão, como sugere Burguess, a urbanização em Santos aconteceu de maneira descontínua, pois enquanto o centro expandia sua área comercial expulsando as "classes perigosas" e eliminando os cortiços, as elites dirigiam-se diretamente ao outro lado da ilha, a orla sul ${ }^{46}$, construindo seus palacetes e dando a direção da expansão:

"Quando o que os santistas até hoje chamam de 'cidade', ou seja, os [atuais] bairros do Centro, Paquetá e Valongo tornam-se super povoados e poluídos, com cocheiras, e muitos ratos, as pessoas que podiam mudavam-se para a Barra, que hoje nós chamamos de orla da praia, indo morar em chácaras aprazíveis. Grandes chalés dos abastados, construídos como se fossem mansões, projetados por profissionais, começaram a aparecer junto com os cassinos e grandes casarões (...) Quem podia, transferia-se para a Barra, para longe da área ocupada nos séculos anteriores. Uma nova Santos surgia. O espaço entre a área antiga e a Barra foi ocupado em terceiro lugar". (Andrade, 2005)

Essas terras intermediárias eram planícies alagadiças entrecortadas por riachos e ribeirões, que eram, até então, utilizados como depósito de lixo. Aqui temos um exemplo do segundo fator, que segundo Burgess (1929), influencia a organização da expansão urbana: a topografia e a hidrografia. Por isso aquelas terras foram as últimas a serem ocupadas. O terceiro fator, que são as vias e os meios de transporte, também age, pois é ao longo das

\footnotetext{
${ }^{46}$ Villaça (1998) também aponta uma tendência crescente de ocupação da orla inicialmente pelas camadas de alta renda. Os primeiros casos que aponta são Rio de Janeiro e, justamente, Santos.
} 
avenidas que davam acesso á Barra (orla) que se construíram as primeiras casas, e depois da implantação das linhas de bonde a ocupação se intensificou.

Como em terras alagadas não era possível haver linhas de bondes, o primeiro transporte que houve foi por meio de gôndolas, em 1864, que deu prejuízo e não foi adiante. Em 1866 começaram os serviços de diligência, que até ofereciam viagens a São Paulo, mas que logo cessa com a inauguração da ferrovia, em 1867.

Mesmo antes da implantação da rede de esgotos e da rede de drenagem, foi inaugurada a primeira linha de bondes, ainda puxados por burros, em 1870, de iniciativa privada. Em 1873 foi ampliada para a "Barra do Embaré" [a orla da praia do atual bairro do Embaré], já apontando para a direção que tomava a área residencial de alta renda. Só em 1887 criou-se linhas de bondes para o bairro de Vila Mathias, bairro operário, fornecida pela firma Matias Costa e Santos, proprietária da Empresa de Bondes Vila Matias. Trata-se, aqui, da atuação de uma das grandes personagens da História de Santos, fundador do bairro de Vilas Matias e proprietário da maioria das casas que eram alugadas para os operários que desejavam habitar em residências melhores que as próximas do porto. Vila Mathias (ou "Matias", como escreve Olao Rodrigues (1980), pode ser considerada uma área da Zona 3 da estrutura urbana daquela época, uma "Zona da Casa dos Trabalhadores Independentes", como chamou Burgess. Em 1889, a mesma empresa instala um ramal para a atual Rua Marcílio Dias, onde se situava o botequim do Sr. Luiz Gonzaga que deu origem ao bairro do Gonzaga. Em 1909 é implantada o serviço de bondes elétricos pela The City of Improvements Co, que administrou as linhas até 1952, quando o Serviço Municipal de Transportes Coletivos comprou os carros e manteve as linhas até 1971, ano em que começaram a funcionar os ônibus a diesel. 


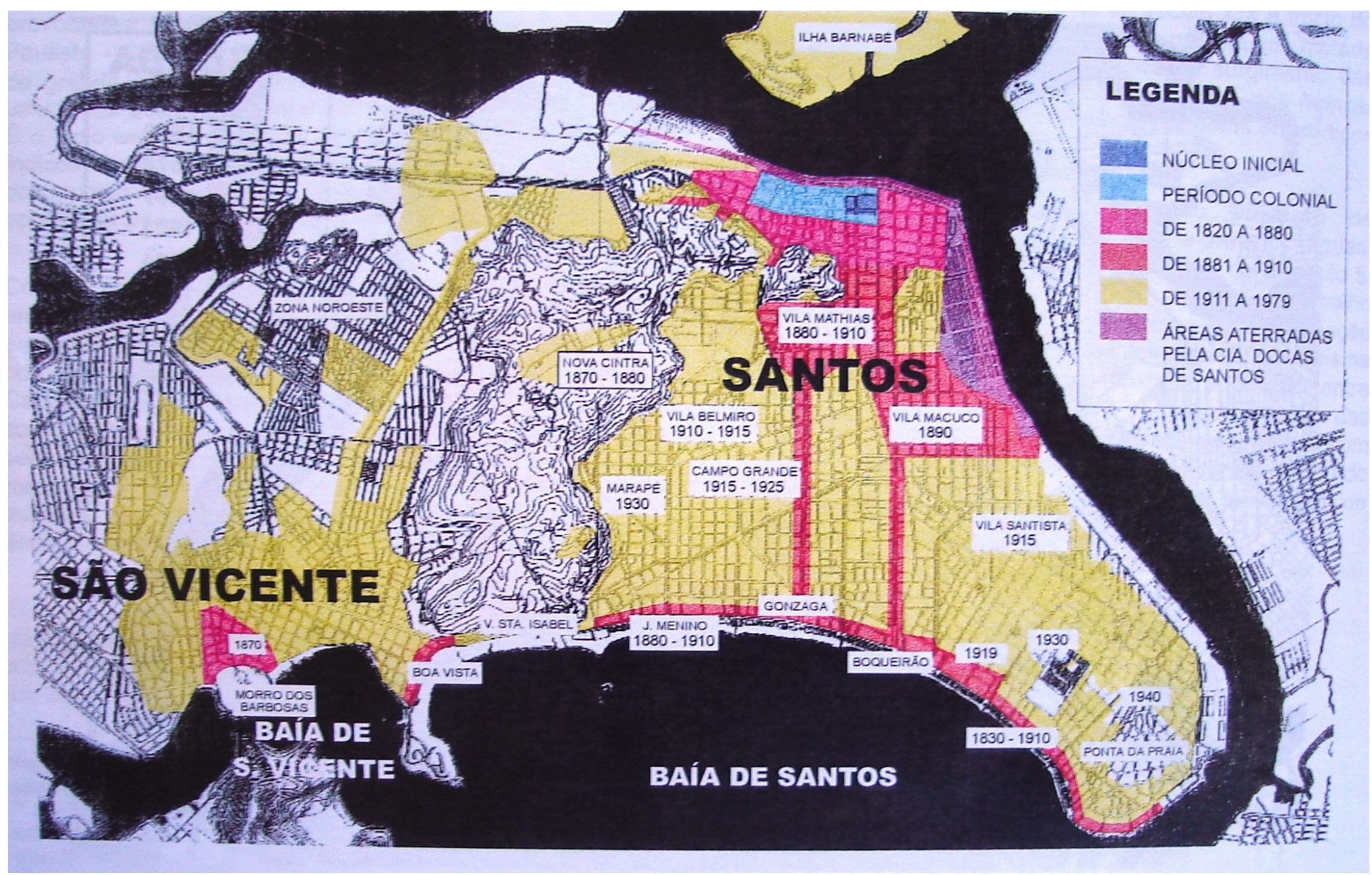

Figura 8: Cronologia da ocupação da Ilha de São Vicente, até a década de 1979. Esse mapa já está com a orla sul em destaque, ao invés dos mapas antigos que colocavam a orla norte na parte central do mapa. Note-se que toda a orla foi ocupada anteriormente aos bairros que receberam canais, e as vias que receberam bondes foram as próximas (Ana Costa e Conselheiro Nébias). A área entre essas duas primeiras ligações com a orla foi justamente a escolhidas pela classe de alta renda (chamada de "Vila Rica"). Foram ocupadas em seguida as terras entre os canais. Elaborado por Carriço (2002) através dos mapas históricos apresentados em Andrade (1989:201), dos mapas de Araújo Filho (1965) e Seabra (1979), em Carriço, (2002, p.38). 
De acordo com essa seqüência histórica de implantação dos transportes, as primeiras áreas a serem atendidas eram as residenciais de alta renda, ou as que estavam no caminho dessas áreas. Como sugeriu Hoyt, a classe de alta renda ao posicionar sua área residencial, atrai, com ela, os serviços essenciais, como os transportes, e com eles, a expansão de todas as outras áreas residenciais. A tendência dos transportes, que foram criados por iniciativa privada em todos os casos, era ligar as áreas centrais com a Barra (orla da praia), e essa foi a mesma tendência da expansão urbana posterior.

Realizadas, então, as obras de implantação da rede de drenagem, aterramento, oficialização das ruas, calçamento, abertura de valas e extensão dos meios de transporte entre o centro e a praia, as terras indesejadas ocupadas somente pelos trabalhadores braçais do porto que não tinham dinheiro para morar perto do local de trabalho (Valongo), passaram a ser disputadas pela classe média e de alta renda que se formavam. Segundo Lanna (1996), crescia o número de pequenos comerciantes que ofereciam serviços à população e os estabelecimentos de insumos à produção do café. Havia ainda os funcionários de médio e alto escalão da Cia. Docas, e os próprios negociantes e comissários que finalmente se arriscavam a habitar a cidade.

Já não importava mais estar nas terras próximas ao comércio do café, mas sim próximo ao banho de mar. Essas terras hoje são os bairros de Campo Grande, Marapé, Vila Mathias, Encruzilhada e Boqueirão. A expansão da cidade iniciada nas terras próximas ao porto tornou-se nesse sentido, como na teoria de Burgess (1924), radial $^{47}$ : do centro para a periferia em direção ao mar.

Nesse caso é importante salientar novamente a força orientadora da elite e o movimento de transbordamento das zonas urbanas. Quando foi necessário, nem o alagamento, a umidade e a insalubridade foram barreiras para a expansão da cidade, que tratou de resolver esse problema com a força do capital. Ao mudar sua localização residencial, empurrada pelo avanço de seus próprios negócios, a classe de alta renda interferiu em toda a dinâmica de expansão da cidade, revelando a existência de uma lógica

\footnotetext{
${ }^{47}$ Uma cidade litorânea não pode ter uma expansão radial ao "pé da letra”, mas essa exceção estava prevista na teoria, que é apenas uma proposição de um tipo ideal, como vimos no capítulo anterior.
} 
estrutural intra-urbana, que com vimos, foi captada por Burgess (1922-25), Hoyt (1939) e detalhada em Villaça (1998), para as metrópoles litorâneas.

No período em que o capital cafeeiro exportador era o principal propulsor da economia brasileira, Santos foi uma cidade com importância estratégica para todo o país e principalmente para o Estado de São Paulo. No estudo da formação do seu espaço intraurbano não devemos dissociar os processos urbano-regionais - como a construção da ferrovia, do porto, e a acumulação de capital regional - da apropriação das conseqüentes melhorias infra-estruturais intra-urbanas pela classe de alta renda residente na cidade. Nesse sentido, pode-se dizer que a lógica estrutural intra-urbana atuante hoje emergiu de uma conjunção de fatores, que, a nosso ver, reafirmam a importância dos modelos de explicação de estruturação urbana de Burgess e Hoyt para o primeiro processo de constituição de áreas naturais separadas e delimitadas na cidade, ou, dito de outra forma, de separação das classes sociais no espaço residencial, ou, ainda de outra maneira, de estruturação do espaço intra-urbano da cidade capitalista.

Os primeiros e mais importantes desses fatores intra-urbanos são a mudança de localização da área residencial de alta renda e o transbordamento do centro, ocasionando a sucessão em sua área circundante. Sob esse contexto é que acontece o saneamento das terras intermediárias entre o centro e a praia, que começam a adquirir maior valor econômico, principalmente depois da construção das avenidas Ana Costa, ligando a Vila Mathias à praia, e da avenida Conselheiro Nébias, melhorando a passagem do centro para o mar.

A expansão urbana tomou, pela terceira vez, nova direção, deixando o vetor planalto/Cubatão para voltar-se para a orla leste da Ilha. Ao longo das três primeiras décadas do século XX, a construção sequiente dos canais foi, aos poucos, formando vias de acesso à praia, ao delinearem avenidas nessa direção. Foram, naquela época, nove canais ${ }^{48}$, que viabilizaram a expansão por toda a ilha, com mostra o quadro a seguir:

\footnotetext{
${ }^{48}$ Apenas os canais de 1 a 6 ligam diretamente a praia com o centro da cidade. Os canais 7,8 e 9 não são chamados pelo número pela população, por serem canais menores, a não ser o canal 9, que é chamado de canal zero", por ficar a esquerda do canal 1. Além destes, há mais seis canais construídos recentemente pela prefeitura, na Zona Noroeste, já fora do plano de Saturnino de Brito. Informação sobre os canais extraída de http://www.canaisdesantos.com.br em 24 de julho de 2006.
} 


\begin{tabular}{|c|c|l|}
\hline \multicolumn{3}{|c|}{ Quadro 1: Inauguração dos canais de drenagem em Santos: } \\
\hline Canal & $\begin{array}{c}\text { Ano } \\
\text { inauguração }\end{array}$ & Avenida correspondente \\
\hline Canal 1 & 1907 & Pinheiro Machado \\
\hline Canal 2 & 1910 & Bernardino de Campos \\
\hline Canal 3 & 1923 & Washington Luiz \\
\hline Canal 4 & 1911 & Siqueira Campos \\
\hline Canal 5 & 1927 & Joaquim Montenegro \\
\hline Canal 6 & 1917 & Francisco Manoel \\
\hline Canal 7 & 1911 & Moura Ribeiro \\
\hline Canal 8 & 1912 & Barão de Penedo \\
\hline Canal 9 & 1911 & . \\
\hline
\end{tabular}

Fonte: Sítio http://www.canaisdesantos.com.br , 2006.

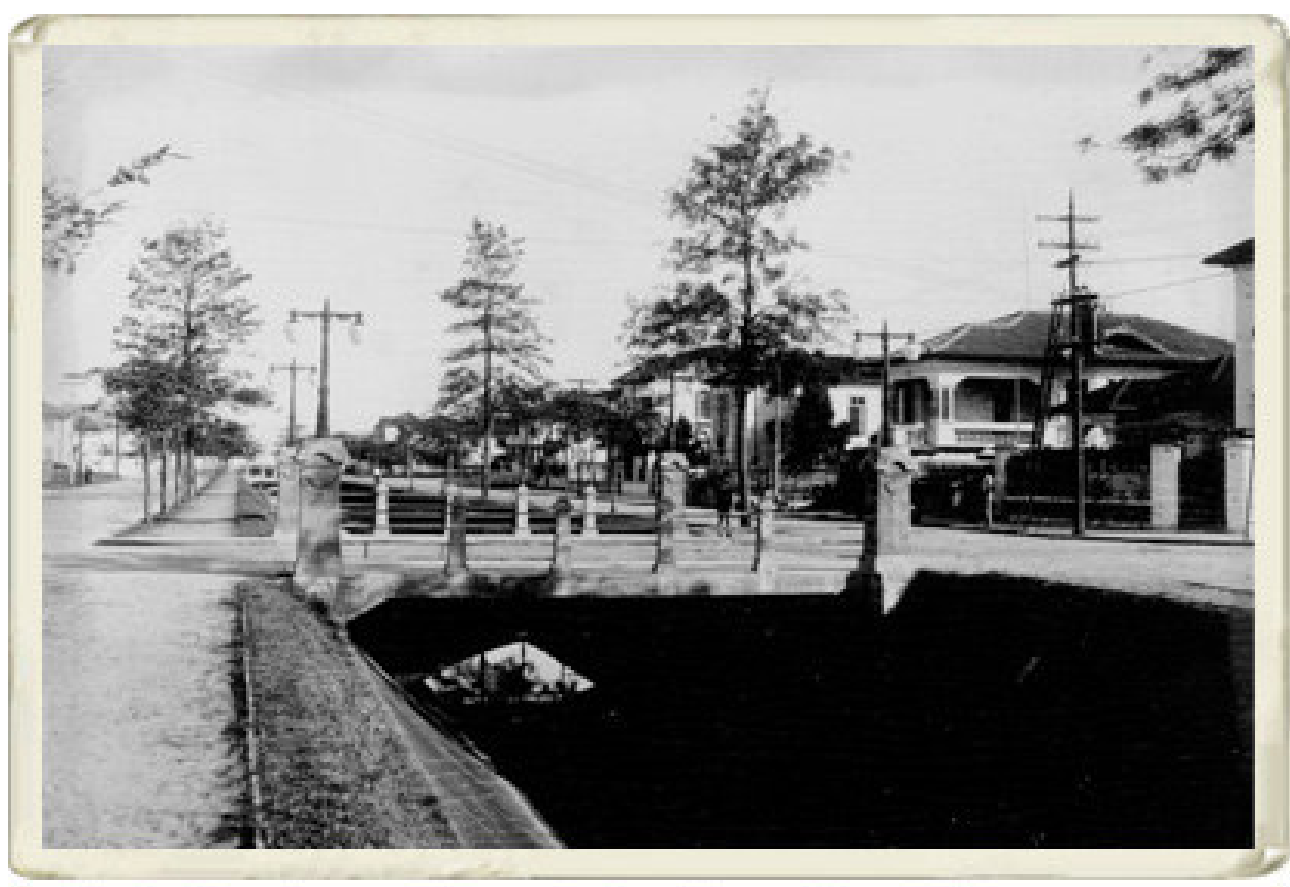

Vista do Canal 1 em 1939 - Autor: Sophia Pretzel Waldhein

Figura 9: Não havia chalés de madeira ao longo dos canais, local privilegiado das classes média e de alta renda. Imagem extraída de http://www.canaisdesantos.com.br em 05/06/2006. 
Posteriormente, outros fatores de estruturação urbana agiram enfatizando a nova direção, como a implantação das linhas de bondes. Essas linhas e a abertura das avenidas supracitadas representaram os primeiros vetores da trajetória de setores residenciais de classe média e alta ${ }^{49}$. O acesso aos meios de transporte permite que se privilegie o consumo e o lazer para definir a localização da área residencial e se deixe de priorizar a proximidade do local de trabalho. Lanna (1996) registra essa separação de funções no espaço da cidade:

"Já na virada para o século XX, com a modernização, saneamento e expansão da cidade, passaram a ser recorrentes notícias informando sobre a separação do local de trabalho e moradia tanto para empregados como para empregadores. (...) $\mathrm{O}$ crescimento dos órgãos públicos e seus empregados também contribuiu de maneira decisiva para o aparecimento não só de bairros com características marcadamente residenciais, mas, sobretudo das habitações unifamiliares, com esposa, filhos, empregados e jardins" (Lanna, 1996, p.103).

Desde a implantação das vias de ligação do centro com a praia da orla sul, a praia começava a ser freqüentada também pelos santistas:

“As Avenidas Conselheiro Nébias e Anna Costa (...) já aproximavam os santistas das praia arenosas, modificando os hábitos locais. Agora as praia do Embaré e Itararé eram mais uma possibilidade de lazer para os santistas, que antes limitavam-se aos circos de cavalinhos, sempre de passagem, aos concertos dados pela banda dos Bombeiros,quando as noites eram boas, nas praças públicas e à festa anual do Monte Serrate, em setembro” (Gitahy 1992, p.32).

Antes da abertura dessas avenidas, somente aqueles que possuíam seus casarões na orla, geralmente construídos em frente à Avenida Ana Costa e depois em direção ao José Menino, é que freqüentavam a praia, que era local de estadias de veraneio de barões do café do interior de São Paulo, sem nenhuma relação com a vida urbana de Santos, conforme Lanna (1996), Araújo Filho (1965) e Seabra, (1979), que assinala: “Por volta dos anos 1930

\footnotetext{
${ }^{49}$ Note-se que a ordem da construção dos canais não foi linear. Uma causa pode ter sido maiores dificuldades em desapropriar terrenos que estivem no caminho da construção. Justamente o canal 3, próximo à avenida Conselheiro Nébias, no centro da Vila Rica foi o último a ser inaugurado. Mas essa é apenas uma hipótese, que merece ser averiguada em outro trabalho.
} 
os segmentos mais abastados da sociedade santista já habitavam em caráter permanente a orla entre o Gonzaga e o Boqueirão, ou mais precisamente, entre a Ana Costa e a Conselheiro Nébias, na área posteriormente denominada Vila Rica” (p.16). Devemos notar que nessa época, as avenidas, as linhas de bondes até a praia e os canais já haviam sido concluídos.

Ou seja, à medida que se formava um modo de vida capitalista predominantemente urbano com a formação das classes sociais, uma das tendências da estruturação urbana passou a ser a da separação: tanto dos locais de trabalho e de consumo, como das áreas residenciais das classes sociais, que até então, se formavam predominantemente no mercado portuário: os negociantes, comissários, funcionários da CDS dirigiam-se para a Barra, deixando o Valongo e o Paquetá. Nasceram também as localizações intra-urbanas: a cidade passou a ter áreas e pontos diferenciados, cada um com uma função e um significado social. A acessibilidade e a facilidade de deslocamento passaram a valorizar e definir a localização das áreas residenciais. Criou-se uma rede de transporte e de vias urbanas para facilitar o deslocamento, privilegiando a classe de alta renda, como vimos em parágrafos anteriores. As classes trabalhadoras, expulsas dos cortiços, não tinham como acompanhar a valorização e partiram para a autoconstrução dos chalés de madeira, invadindo terrenos do Marapé, Campo Grande, as encostas do Morro, ou se dirigindo para os próprios morros, como conta novamente Andrade (1989, p.212-215). Aqueles trabalhadores em melhores condições partiam para a Vila Mathias. A drástica reforma social sanitarista já mencionada, o aumento do preço das terras e a própria desapropriação de terrenos para as reformas ${ }^{50}$ deslocaram boa parte dessa população para a zona noroeste da ilha, longe das praias, ao pé dos morros, em direção a São Vicente. Nesses novos bairros a ocupação foi desordenada; convenientemente a administração pública não cobrava o cumprimento do Código de Posturas de 1897 e "só aparecia para recolher impostos" (Araújo Filho, 1965). Foi a ocupação mais recente da cidade, e até hoje a mais pobre. Houve também aqueles que se deslocaram para as terras defronte ao porto, na Ilha de Santo Amaro, formando o bairro de

\footnotetext{
${ }^{50}$ Esse conjunto de reformas urbanas (construção do cais, dos canais, da rede de drenagem, etc) não foi feito pacificamente. Houve muita luta da população local, sobretudo da classes trabalhadoras que tinham seus terrenos desapropriados, sem recursos para reavê-los (pois passavam a valer muito mais). Lanna (1996) e Gitahy (1992) analisam esse aspecto político da remodelação de Santos e demonstram como em Santos a questão da moradia expôs claramente a luta de classes.
} 
Vicente de Carvalho, hoje pertencente ao município de Guarujá. Iniciou-se desde então a "periferização": o afastamento das classes pobres das áreas centrais da cidade para as periferias.

Os depoimentos de alguns idosos sobre suas moradias na cidade demonstram claramente como participaram de processos de sucessão entre zonas urbanas, tanto por ascensão social como por limitações impostas pelos movimentos do mercado imobiliário e do poder público local. Assim conta o casal Aurélio, de 74 anos, mineiro que veio trabalhar na CDS e Laurinda, 71 anos, portuguesa. Antes de se casar, Aurélio morou em duas pensões próximas ao Porto, que era a mesma zona central da cidade, podendo ser considerada para nós como a zona de primeira fixação de imigrantes. Depois que se casaram, para ter uma casa só para eles, foram para o bairro Jardim Rádio Clube, na Zona Noroeste entre as décadas de 1950 e 1970. Hoje moram no Marapé [bairro de classe média entre o centro e a praia]. Nos trechos a seguir, podemos identificar como a zona central foi se expandindo e como, de fato, os bairros da periferia nascente foram esquecidos. Enquanto nos anos 30 já havia no Boqueirão e no Gonzaga bondes elétricos, no Radio Clube nos anos 1950 não tinha nenhum tipo de condução:

Laurinda: Hoje a gente vê aquilo lá e não imagina! A gente não tinha nada. Morávamos lá sem água, sem luz e sem condução. Até chegar na Nossa Senhora de Fátima [principal avenida da Zona Noroeste, que liga todos os bairros], eu estava grávida da minha segunda filha. Carregava água com carrinho de mão porque não ia o caminhão da prefeitura...

Juliana $^{51}$ : Não tinha água encanada?

Laurinda: Não. O caminhão da prefeitura levava de noite e tinha umas caixas [caixas d'água] espalhadas no bairro. (...)

Aurélio: No Rádio Clube era [casa] própria. Aí alugamos lá e viemos pra cá [bairro Campo Grande, Zona Leste, pode ser considerado como da terceira

\footnotetext{
${ }^{51}$ Preferi usar meu próprio nome para designar minhas falas ao invés de "pesquisadora", ou "entrevistadora" porque é preciso levar em conta que essas respostas foram direcionadas à minha pessoa, de 25 anos, do sexo feminino. No caso das entrevistas feitas na rua, a minha aparência jovem intimidava inicialmente (demoravam a acreditar que eu era uma pesquisadora) e às vezes a conversa inicial explicativa sobre as minhas intenções científicas era muito maior do que a própria entrevista. Tudo isso pode ter influenciado no peso que se dava a um assunto ou outro (como quando faziam questão de dizem que não estavam tão velhos quanto eu poderia pensar).
} 
zona urbana] porque para a minha filha mais velha era muito dificultoso o negócio de condução; tinha que andar uma meia hora de casa até a linha do ônibus na avenida para pegar uma condução para cá. E ela estudava de dia e de noite; às vezes ela chegava em casa duas horas da manhã e de manhã tinha que levantar cedo porque ela tinha arranjado um emprego na Alfândega [centro, próxima ao Porto]. (...) Era aquela dificuldade, então resolvemos alugar a casa lá no Rádio Clube e alugamos aqui na Clemente Pereira [bairro Campo Grande] Ali moramos uns 12 anos de aluguel. Então, quando me aposentei eu tinha o meu fundo de garantia e alguma bobaginha mais... Então eu falei para a Laurinda: “Eu vou aposentar, tenho casa lá no Rádio Clube e vou ficar aqui pagando aluguel? Vamos dar um jeito.” (...) Aí foi quando vimos a casa lá na Manoel Tourinho, no Macuco [bairro próximo ao centro, zona de transição]

Laurinda: Perto da Xavier Pinheiro.

Aurélio: É, aí deu para a gente fazer negócio... Quando a gente foi para lá ainda era bom, tinha o Portuários [clube de lazer Associação Atlética dos Portuários], era bom, mas agora não presta [para morar]. Então a gente morava ali e era legal porque sempre tinha movimento... Mas, depois que o Portuários saiu dali, aquilo ficou um deserto! A gente ficou isolado ali.

Laurinda: Todo mundo vendeu as casas.

Aurélio: Depois abriram um frigorífico geminado na minha parede, e começou a estragar coisa lá... Eu falava lá com dono, inclusive o dono ajeitava, e coisa e tal... Aí um belo dia apareceram os crentes da Assembléia Deus perguntando se eu queria vender a casa.

Laurinda: Ficou tudo comercial. Depois construíram uma faculdade, tem um estúdio, tem uma igreja que tem outro nome lá...

Juliana: E só vocês morando por ali?

Laurinda: Só, ali sozinhos (...) Então nós fomos à imobiliária onde tínhamos comprado a outra casa lá na Manoel Tourinho e aí ele falou: “a casa que a senhora gostou [uma casa de dois quartos no Marapé, Saturnino de Brito, 
área residencial de classe média] está a venda de novo” (...) Isso foi há 10 anos atrás... [a casa onde essa entrevista foi realizada].

\section{2 "Mais outras funções": o terceiro momento de estruturação urbana.}

Depois que o sucesso do porto do café e a posterior reforma urbana deram o impulso que faltava ao crescimento da cidade que ficara estagnada por quase 300 anos, outras duas "funções", como chamou Araújo Filho (1965), ou "vocações", viriam a fazer crescer ainda mais a região: a indústria e o turismo.

Em 1926, instalou-se, em Cubatão, a Light para fornecer energia elétrica para as indústrias em São Paulo. A usina acabou atraindo a instalação de indústrias naquela área, que ficava entre o maior porto e a maior capital econômica do país. Formou-se, então o Parque Industrial que se consolidaria a partir dos anos 1950, com a construção da COSIPA (Companhia Siderúrgica Paulista), seguida da Ultrafértil (hoje Fósfértil) e do pólo petroquímico da Petrobrás. Quando se iniciou o período de construção dessas indústrias de base, e de grandes obras de infra-estrutura como a Via Anchieta, um novo impulso migratório se constituiu com imigrantes de diversos estados do país, mas principalmente do próprio estado de São Paulo e de estados nordestinos, de um modo geral, como nos demonstra o trabalho de Jakob (2003) para o período de 1959 a 1970.

Vale a pena destacar que entre os estados nordestinos, foi grande a participação dos sergipanos em Santos e em Vicente de Carvalho (até apareceram entre nossos entrevistados), mas a maioria dos migrantes vinha cada vez mais do estado de São Paulo, e mesmo de dentro da própria $\mathrm{RMBS}^{52}$, apesar de que muitos que vinham de outras cidades de São Paulo, já estavam na sua segunda etapa de migração, podendo ser ainda maior o número de migrantes nascidos em outros estados. Além das indústrias, outra grande fonte geradora de empregos atraía para Santos muitos indivíduos em busca de trabalho: a construção civil para o turismo de veraneio.

\footnotetext{
${ }^{52}$ Jakob (2003) chama a atenção para a impossibilidade de desagregar a migração intra-metropolitana da migração intra-estadual nos censos de 1960 e 1970, de forma que entre o aumento dos migrantes com UF de nascimento SP, pode estar oculta um aumento dos migrantes nascidos na RMBS.
} 
Com a crise econômica iniciada em 1929, os palacetes da elite cafeeira foram, em parte, abandonados e transformados em pensões para turistas (Araújo Filho, (1965) e Seabra, 1979) A inauguração da Via Anchieta em 1947 facilitou o acesso das famílias do interior a Santos, com o advento do automóvel, que se popularizava. Criou-se uma nova força de circulação de pessoas, que buscavam consumo da paisagem natural, e não trabalho ou a realização de negócios. Santos agrega outro motor de estruturação urbana: a população flutuante.

Para esse público em crescimento iniciaram-se os empreendimentos imobiliários de prédios de apartamentos de veraneio, ou seja, a preparação de um ambiente construído voltado para o consumo e o lazer. Santos passou, na década de 1950, a ser destino freqüente não só da população flutuante, mas de milhares de paulistas e nordestinos que vinham erguer a "Muralha que cerca o mar", como chamou Odete Seabra referindo-se aos edifícios de apartamentos de segunda residência. Mas as habitações da orla da praia, como bem demonstrou a mesma autora, foram construídas para serem vendidas, e não para atender ao seu pronto valor de uso. Assim, estes terrenos alcançaram os maiores preços possíveis dentro do mercado imobiliário para turistas, e não se abriram para o uso residencial dos santistas. Até fins da década de 1960 perdurou essa exploração econômica da paisagem natural das praias, mas com a construção de rodovias para outros municípios praianos e com a perda de balneabilidade das praias santistas, a população flutuante se espalhou pela RMBS.

Dessa forma, as vagas na construção civil foram diminuindo gradativamente, e na segunda metade da década 1970 esse mercado já estava saturado, como assinala a própria Seabra (1979) e observamos nas análises de Jakob (2003). Nessa época, no entanto, algumas indústrias ainda se instalavam em Cubatão ${ }^{53}$ e reacendiam a migração de mão de obra para a cidade, dessa vez, de mão de obra qualificada ocupando alguns dos apartamentos outrora de segunda residência, e apartamentos nos quarteirões logo atrás da orla. A migração nordestina continuava forte, mas nos anos 1970 dirigia-se menos para

\footnotetext{
${ }^{53}$ Segundo o site da prefeitura de Cubatão, das 25 indústrias existentes na cidade, 18 foram implantadas entre 1955 e 1975. Ver http://www.cubatao.sp.gov.br/noticia.asp?codigo=246\&COD_MENU=82 .
} 
Santos e mais para Cubatão e outros municípios mais distantes como Itanhaém e Mongaguá (Jakob, 2003).

De um modo geral, entre 1959 e 1970 a migração causou o aumento do espaço urbanizado da RMBS, desconcentrando-se cada vez mais dos municípios centrais. Por outro lado, tornou-se cada vez mais definida quanto à origem e destino dos migrantes, concentrando os migrantes intra-metropolitanos em Praia Grande, que passou também a receber mais migrantes nordestinos. Santos recebia migrantes de outros estados e do interior do estado de São Paulo predominantemente na década de 50, começando a perder população para municípios vizinhos já na década de 1970. Na década de 1980 o fluxo de migração intra-metropolitana de Santos para outros municípios da região já estava consolidado, e na década de 1990 seu saldo migratório (que leva em conta todas as trocas migratórias, tanto as intra-metropolitanas quanto as intra e interestaduais) chegou a níveis negativos.

O exame dos arranjos familiares do migrante também revela essa desconcentração espacial da região com aumento da segregação espacial em Santos. O número de casais com filhos (família nuclear) que chegavam era cada vez menor, em detrimento de casais sem filhos ou de indivíduos sozinhos procurando trabalho. Os casais com filhos migrantes foram mais observados em Vicente de Carvalho, distrito de Guarujá próximo à Santos, e tinham menor poder aquisitivo do que os casais com filhos residentes em Santos. Ou seja, já nos anos 1970 as famílias jovens não conseguiam estabelecer-se em Santos, quando as habitações de segunda residência encareceram ainda mais a orla da praia e os espaços próximos a ela, aumentando a pressão imobiliária que acompanhou historicamente o crescimento do município. Na avaliação de Jakob, Santos era alvo de migrantes em busca de trabalho, e não de famílias que chegavam por meio de redes sociais para começar vida nova:

"Nos anos 1970 deve ter havido uma migração que visava mais a busca do emprego nas faixas etárias mais próprias ao trabalho e com menos filhos. (...) Nesse período foi significativo o aumento dos migrantes nordestinos para os municípios mais próximos ao parque industrial da Baixada, como Cubatão, Guarujá, Santos e São Vicente. Assim, com relação aos migrantes não metropolitanos, a ocupação dos espaços mais centrais da Baixada Santista foi dada principalmente por migrantes em 
busca de trabalho, possuindo menos filhos e a ocupação das áreas mais periféricas, por migrantes com maior número de filhos.” (Jakob, 2003, p.60).

A partir da década de 1980 é possível considerar que se inicia em Santos uma nova dinâmica demográfica, que acompanha o momento sócio-econômico do município e acentua alguns processos de estruturação urbana relacionados à segregação residencial e à periferização da classe de baixa renda. Nessa década, além de diminuição da entrada de migrantes, começou a crescer o número de pessoas procurando trabalho em Santos (desempregadas). O filão dos edifícios de veraneio já tinha se esgotado e o porto passava por redução de postos de trabalho, com a conteinerização ${ }^{54}$. Como vimos no primeiro capítulo, o número de aposentados em Santos já era maior que o das outras cidades da região desde 1959, e o peso dessa faixa da população aumentava, à medida que diminuía o peso daqueles que trabalhavam. Além disso, Santos finda os anos 1980 com praias poluídas e os maiores índices de doentes de AIDS.

A década seguinte continua a retração no mercado de trabalho decorrente do declínio da função turística e da diminuição das atividades do setor da construção civil. As indústrias, ao invés de empregar, passavam por processos de privatização e reestruturação produtiva, diminuindo postos de trabalho e terceirizando parte do processo de produção. Houve queda do poder aquisitivo de boa parte da classe média, que trabalhava nas estatais recém privatizadas (COSIPA, Telesp, Fosfértil/Ultrafértil). Nesse período aumenta a migração intra-metropolitana de Santos para outros municípios da RMBS, principalmente de famílias jovens dirigindo-se para Praia Grande. Entre 1991 e 1996 a população total da cidade decresce (de 417.450 habitantes em 1991, para 412.243 em 1996) e o saldo migratório torna a ser positivo nos anos seguintes somente em níveis de reposição de população. Ainda de acordo com o censo de 2000, a taxa de crescimento demográfico da

\footnotetext{
${ }^{54}$ A introdução dos contêineres (grandes caixas de aço que comportam até 50 toneladas de carga das mais variadas mercadorias, de roupas a equipamentos eletrônicos) reduz o número de trabalhadores necessários para descarregar e carregar navios, trabalho feito agora por uma equipe (chamada de "terno") de somente cinco trabalhadores e um guindaste. Nos tempos do café embarcado em sacas, essa equipe envolvia cerca de 50 trabalhadores entre conferentes, consertadores de carga, trabalhadores de bloco e trabalhadores de capatazia (Oliveira, 2000 , p.30 in Diéguez, Carla. M.A.D, Relatório de Qualificação "De Carregadores a Multifuncionais: a nova identidade do trabalhador do Porto de Santos”, São Paulo, Dezembro de 2005, no prelo.
} 
RMBS ficou em 2,13\% enquanto a de Santos foi de $-0,29 \%$ e a de Praia Grande, foi de $5,01 \%$ (Jakob, 2001).

Desde os anos 1950, a parte da cidade que mais cresceu, tanto em população como em expansão urbana foi a Zona Noroeste. Sabemos que nos anos 1990, de acordo com os Sumários de Dados de 1992, produzidos pela Secretaria de Planejamento da Prefeitura Municipal de Santos, a Zona Leste foi a que menos cresceu em termos populacionais. De acordo com a análise de Carriço (2002) sobre as plantas genéricas ${ }^{55}$, os terrenos da Zona Noroeste, embora sempre mais baratos que os da orla, estão em valorização constante. No mesmo período analisado (de 1960 até 2000) o autor notou uma proliferação dos cortiços, mesmo com a construção de apartamentos populares pela Companhia de Habitação de Santos (COHAB-Santos). O solo santista tornava-se cada vez mais valorizado, enquanto sua população perdia, a partir de meados dos anos 1970, oportunidades de emprego e de aumento da renda.

\footnotetext{
${ }^{55}$ As plantas genéricas são produzidas por arquitetos contratados pela prefeitura para saber o preço médio dos terrenos. São utilizadas pela prefeitura para estabelecer o valor dos terrenos sobre os quais incide a cobrança de impostos.
} 


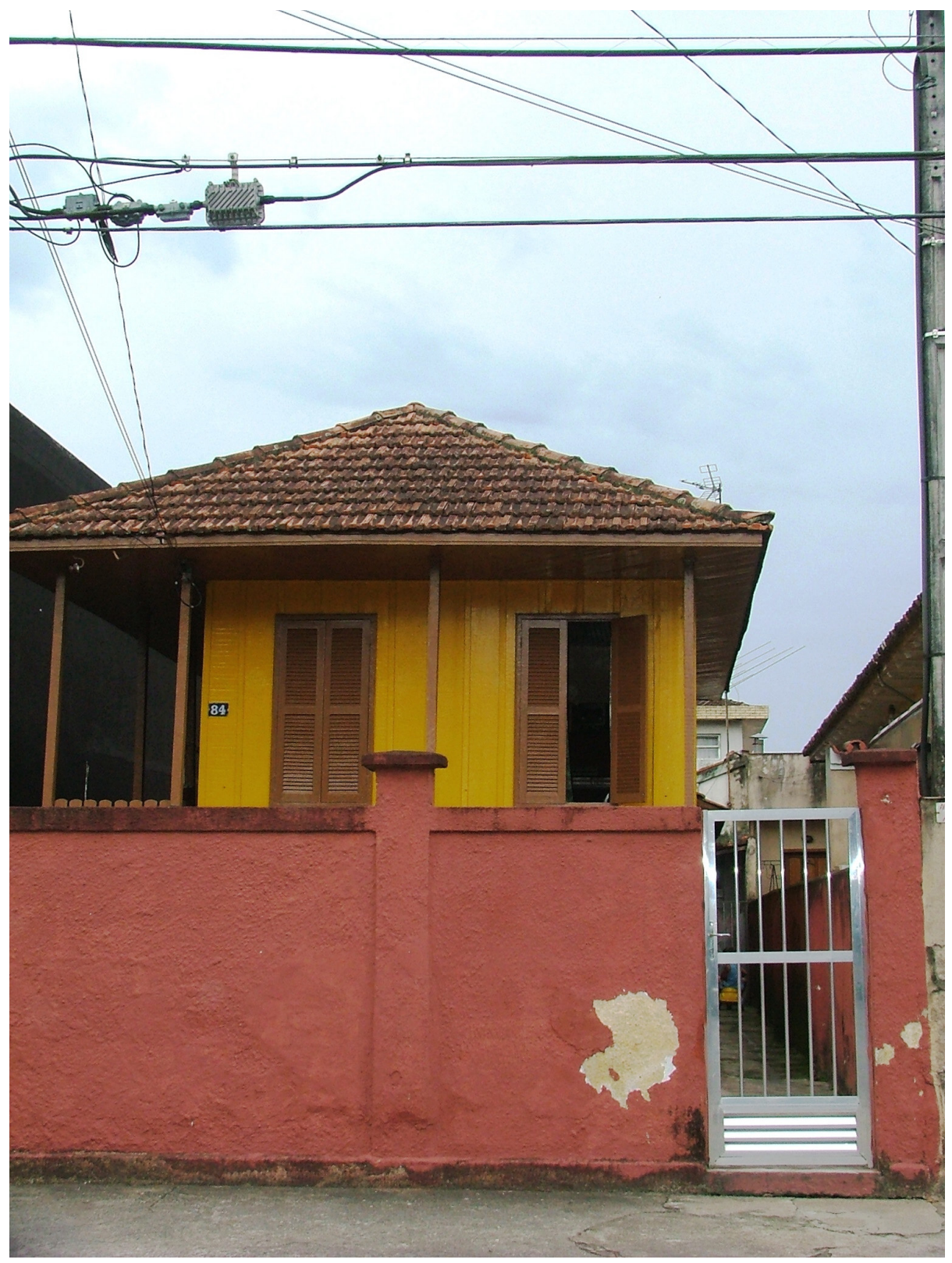

Figura 10: Chalé. Foto de Tatiana Busto Garcia, 2006. 


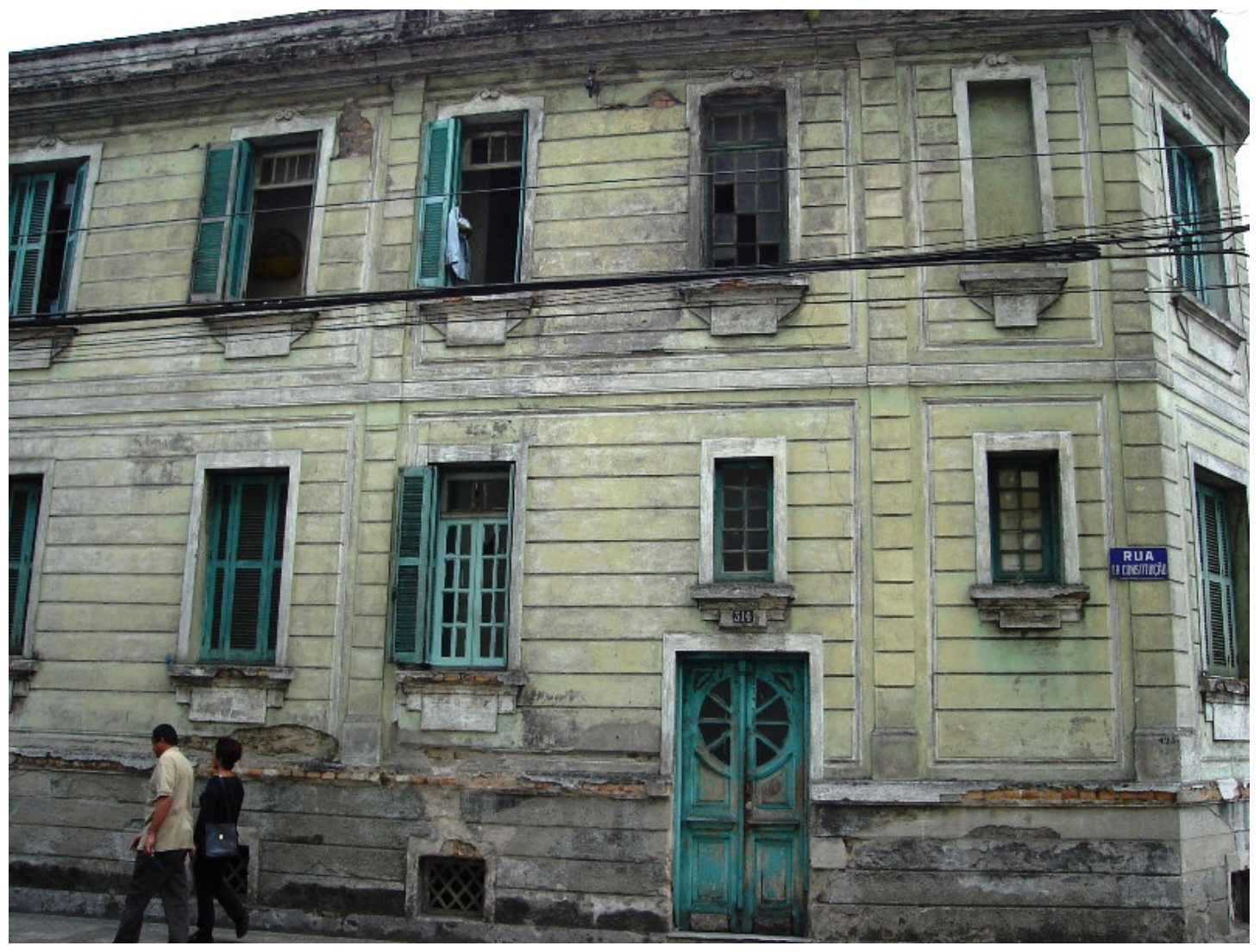

Figura 11: Casarão de quartos sublocados na Rua Constituição (área central), agosto de 2006.

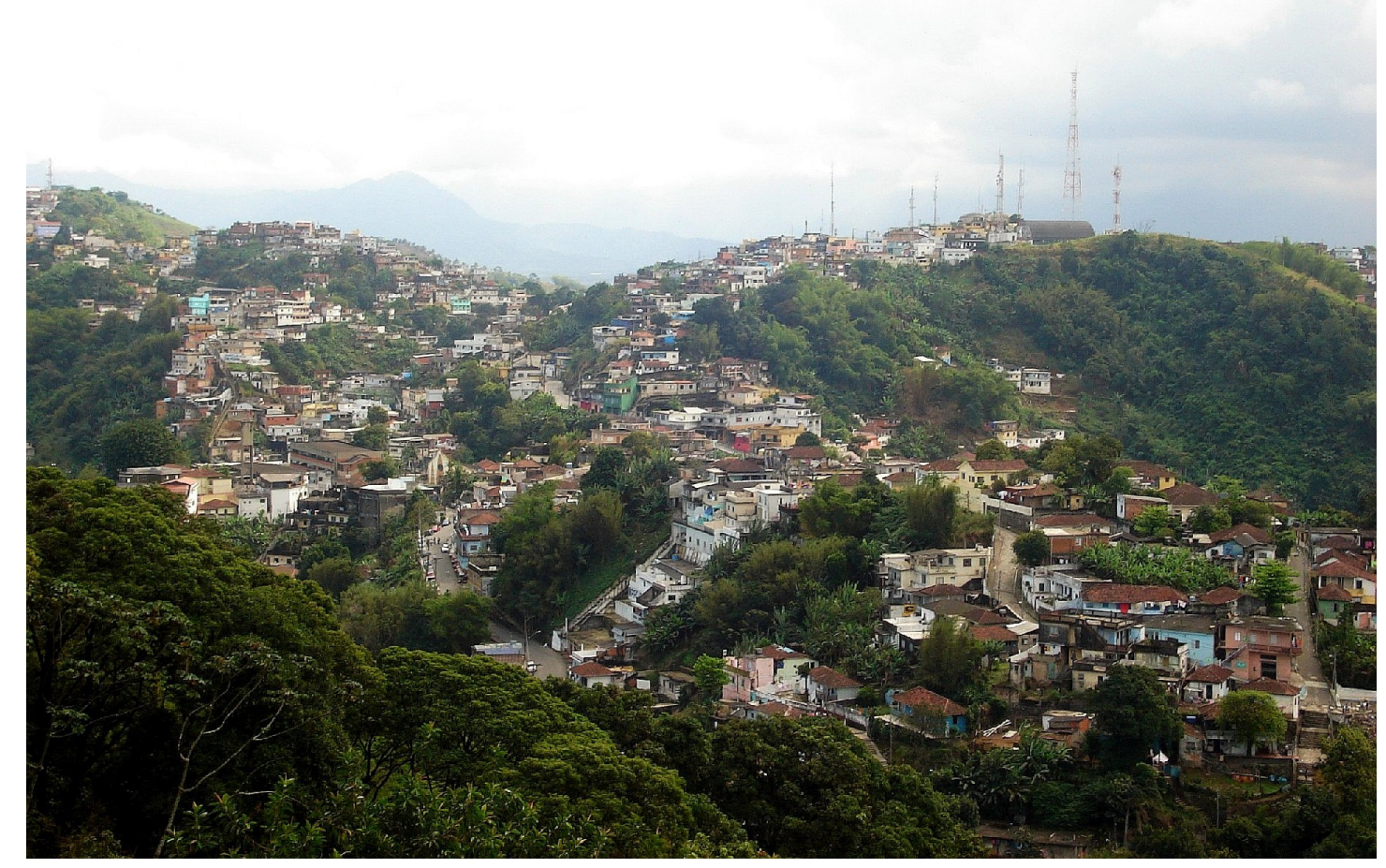

Figura 12: Morro São Bento, visto do Monte Serrat em agosto de 2006. Fotos da autora. 
Jakob (2003) aponta que a década de 1980 foi a que aumentou o número dos muito pobres e dos muito ricos. Carriço(2002), com dados sobre mortalidade infantil também apontou para um aumento da desigualdade social. Os índices de mortalidade infantil variaram muito entre os bairros de alta e baixa renda: índice 0 nos bairros do Gonzaga, Boqueirão e Ponta da Praia e índices de 10,3\% na Vila Mathias, 54,8\% no Centro e 57,1\% no Paquetá, piores do que a média da região Nordeste do Brasil (52,8\%).

Carriço também notou, em pleno ano 2001, uma proliferação de $\operatorname{cortiços}^{56}$ nos mesmos moldes de há quase dois séculos atrás, nos mesmos bairros centrais que tem as maiores taxas de mortalidade infantil. Essa distribuição da mortalidade infantil pela cidade nos permite considerar que há população de baixa renda concentrada na área central. Em nossa pesquisa de campo observamos que há muitos idosos morando sozinhos e ainda famílias com chefes de domicílio com mais de 60 anos nos cortiços do centro, embora segundo a tabulação feita pela Secretaria de Assistência Social da Prefeitura de Santos dos dados censitários, essas pessoas com mais de 60 anos residindo na região central somavam $4,24 \%$ do total da população idosa da cidade. A maioria das pessoas com mais de 60 anos reside nos bairros da Zona Leste, próximos à orla, como mostra a tabela adiante, na página 100.

Com o declínio da presença da população flutuante, alguns imóveis da orla, principalmente os "maiores e melhores", como relata Seabra $(1979)^{57}$, começaram a ser ocupados por santistas de alta renda, e nos últimos anos boa parcela dos apartamentos "menores e piores" tem sido ocupados por aposentados. Essa tendência foi indicada por Jakob (2003) e muitos dos nossos entrevistados também relataram ter se mudado depois da aposentadoria para um apartamento menor na orla da praia.

Os estudos acima mencionados e nossa pesquisa de campo nos permitem concluir que a distribuição espacial da população santista seguiu as mesmas direções apontadas na

\footnotetext{
${ }^{56}$ Os cortiços são classificados pelo Censo Demográfico como habitações subnormais, ou cômodos. Em Santos nos bairros supracitados e no bairro de Vila Nova casarões antigos e deteriorados são alugados por pessoas que sublocam cada quarto a um preço médio de 270 reais, mais a conta de água e de luz, segundo nossa última ida a campo realizada em 2006. A maioria desses cômodos são alugados por famílias migrantes recém chegadas.

${ }^{57}$ Seabra (1979) analisou profundamente os tipos de apartamentos da orla da praia entre os anos 1973 e 1976 . A autora classificou-os em dois grandes grupos: os "maiores e melhores" (de 3 quatros ou mais) e os "menores e piores" ( "quarto e sala", "kitinetes", e de até dois quartos pequenos).
} 
reforma urbana do início século XX, confirmando algumas das tendências apontadas por Hoyt (1971 [1964]), que enfatizou o aumento de população e a introdução do uso do automóvel como os dois principais fatores responsáveis pelas novas tendências que se observavam nas cidades a partir anos 60. Ambos, como vimos, estavam presentes em Santos: tanto o aumento de população, que se deu pela migração, como a construção da Via Anchieta e a instalação de indústrias automobilísticas, que geravam não só os automóveis como a classe média que os usaria para se tornarem população flutuante em Santos, cuja estrutura urbana tomou dimensões metropolitanas.

A classe de melhor renda continuou se afastando do centro: se dirigiu para perto da paisagem natural e das principais vias de transporte e lá permaneceu. É o bairro da Vila Rica, que fica entre as duas primeira avenidas que ligaram o centro à orla da praia (A Ana Costa e a Conselheiro Nébias). No entanto, com a saturação dos terrenos disponíveis, alguns empreendimentos residenciais de luxo começam a ser inaugurados no bairro da Ponta da Praia (dos anos 1990 em diante).

A área de estabelecimentos comerciais e de serviços acompanhou o deslocamento do setor residencial de alta renda. Primeiro o centro "antigo" deixou de ser freqüentado pelas classes médias e de alta renda e consolidou-se o bairro do Gonzaga como centro comercial paralelo ao centro tradicional, sendo o preferido pelas classes médias e de alta renda. Seabra (1979) argumenta que o Gonzaga fortaleceu sua vocação concomitantemente residencial e comercial por causa da grande clientela constituída nos fins de semana pela população flutuante, mas ao nosso ver, a instalação de boa parte da classe média santista nos bairros próximos ao Gonzaga fez com que, mesmo depois do declínio do turismo de veraneio, o Gonzaga permanecesse como área residencial e comercial das mais valorizadas até hoje. Nesse sentido que compreendemos novo vetor de construção de residenciais de luxo em direção ao bairro da Ponta da Praia. Os terrenos dos bairros do Gonzaga, Vila Rica e Boqueirão atingiram valores muito altos e ficaram muito adensados, de forma que se tornaram raros terrenos grandes o suficiente para serem explorados (teriam que ser construídos muitos apartamentos para compensar a compra do terreno). Daí a nova direção da Ponta da Praia, que oferece também bela paisagem natural para consumidores que não precisam estar próximos ao local de trabalho, pois tem meio de locomoção rápida 
(automóvel) para qualquer ponto da cidade, e muitos trabalham em São Paulo. Novamente os estabelecimentos comerciais mais requintados acompanham o movimento, com a construção do Shopping Praiamar e outros serviços que se concentraram na avenida Epitácio Pessoa (paralela à avenida da praia, do canal 4 até o canal 6) afirmando o novo vetor das construções residenciais de alta renda ${ }^{58}$.

Em 1998, o Plano Diretor passou a permitir a construção de prédios com mais de 14 andares. Junto com a duplicação da Rodovia dos Imigrantes (segunda pista inaugurada em novembro de 2002), que aumenta e facilita o fluxo de turistas e pendulares do planalto para a baixada, crescem os empreendimentos imobiliários próximos ou na própria orla da praia, agora, sem limitações quanto ao número de andares. O mais recente e chamativo, "Jardins da Grécia", tem três torres de 24 andares e fica defronte o mar.

Como podemos ver nas tabulações do NESE dos dados do Censo demográfico 2000 dos bairros santistas, a maior parte dos idosos reside justamente nos bairros que abrigam a população com renda de mais de 20 salários mínimos, o que pode indicar que parte da classe de alta renda de Santos é população idosa. Entretanto, não temos dados suficientes para inferir nenhuma relação de proporção; se, por exemplo, a maior parte da elite santista é idosa.

Em conversas com corretores, obtivemos a informação que a principal clientela desses empreendimentos de luxo não são casais idosos, mas famílias com chefes de domicílio entre 30 e 45 anos, de São Paulo e alguns santistas que trabalham em São Paulo. Ainda assim, o morador do condomínio supracitado entrevistado pelo principal jornal da cidade é justamente um senhor de 60 anos que acabou de se aposentar e de adquirir o imóvel $^{59}$. Também entrevistamos dois senhores que depois de se aposentar compraram imóveis (de três quartos e à vista) na Avenida Bartolomeu de Gusmão (orla da praia da Aparecida, Embaré e Ponta da Praia), e Jakob (2003) aponta para um aquecimento do mercado imobiliário voltado às demandas da população idosa.

\footnotetext{
${ }^{58}$ Novamente, lembramos que estamos apontando tendências, o que significa que pode haver (e há) alguns empreendimentos de alta renda na área tradicional de alta renda, o Boqueirão. Entretanto, percebemos que os maiores e mais luxuosos tendem a ser construídos na direção da Ponta da Praia, como o La Grande Maison, um dos edifícios de apartamentos mais luxuosos de Santos inaugurado há menos de três anos em frente ao Shopping Praiamar (bairro do Embaré, duas quadras da praia).

${ }^{59}$ Reportagem “Construção Civil: nas alturas”, publicada no jornal “A Tribuna”, em 17 de abril de 2006.
} 
A maior parte da população idosa santista está concentrada nos bairros da orla da praia, sobretudo nos mais valorizados economicamente: Boqueirão, Embaré e Aparecida. A seguir veremos um conjunto de tabelas e mapas elaborados por Jakob (2003) e pelo Núcleo de Estudos Socioeconômicos da Universidade Santa Cecília que mostra a distribuição residencial da população idosa em Santos, tanto das residências nas quais eles são chefes de domicílio (que inclui aqueles que moram sozinhos), quanto nas que eles apenas moram com outras pessoas. A tabela logo a seguir mostra a distribuição em bairros das pessoas com mais de 60 anos em Santos. 


\begin{tabular}{|c|c|c|c|c|c|c|c|}
\hline \multicolumn{2}{|c|}{ Zona Leste } & \multicolumn{2}{|c|}{ Zona Central } & \multicolumn{2}{|c|}{ Zona Noroeste } & \multicolumn{2}{|c|}{ Morros } \\
\hline Bairros & Pessoas & Bairros & Pessoas & Bairros & Pessoas & Bairros & Pessoas \\
\hline Embaré & 7022 & Vila Matias & 1723 & Jd. Castelo & 1494 & São Bento & 548 \\
\hline Boqueirão & 6995 & Jabaquara & 412 & Jd. Rádio Clube & 1463 & Nova Cintra & 367 \\
\hline Aparecida & 6944 & Vila Nova & 403 & Jd. Santa Maria & 997 & Vila Progresso & 212 \\
\hline Gonzaga & 5834 & Paquetá & 108 & Areia Branca & 862 & José Menino & 211 \\
\hline Ponta da Praia & 5144 & Centro & 97 & Saboó & 809 & Penha & 144 \\
\hline Campo Grande & 4740 & Valongo & 25 & Bom Retiro & 536 & Jabaquara & 132 \\
\hline Marapé & 3373 & & & Caneleira & 206 & Marapé & 129 \\
\hline Macuco & 2912 & & & Jd. São Manuel & 205 & Pacheco & 104 \\
\hline Encruzilhada & 2616 & & & Chico de Paula & 165 & Saboó & 82 \\
\hline José Menino & 1783 & & & Jd. Piratininga & 111 & Monte Serrat & 77 \\
\hline Vila Belmiro & 1739 & & & Alemoa & 11 & Fontana & 55 \\
\hline \multirow[t]{6}{*}{ Estuário } & 858 & & & & & Santa Maria & 43 \\
\hline & & & & & & Santa Terezinha & 21 \\
\hline & & & & & & Chico de Paula & 7 \\
\hline & & & & & & Caneleira & 3 \\
\hline & & & & & & Cachoeira & 3 \\
\hline & & & & & & Embaré & 0 \\
\hline TOTAL & 52.305 & & & TOTAL & 7.773 & TOTAL & 2048 \\
\hline \multicolumn{2}{|c|}{$80,22 \%$} & \multicolumn{2}{|c|}{$4,24 \%$} & \multicolumn{2}{|c|}{$11.92 \%$} & \multicolumn{2}{|c|}{$3,30 \%$} \\
\hline
\end{tabular}

Fonte: Censo 2000, IBGE. Dados elaborados pela Secretaria de Assistência Social da Prefeitura Municipal de Santos 


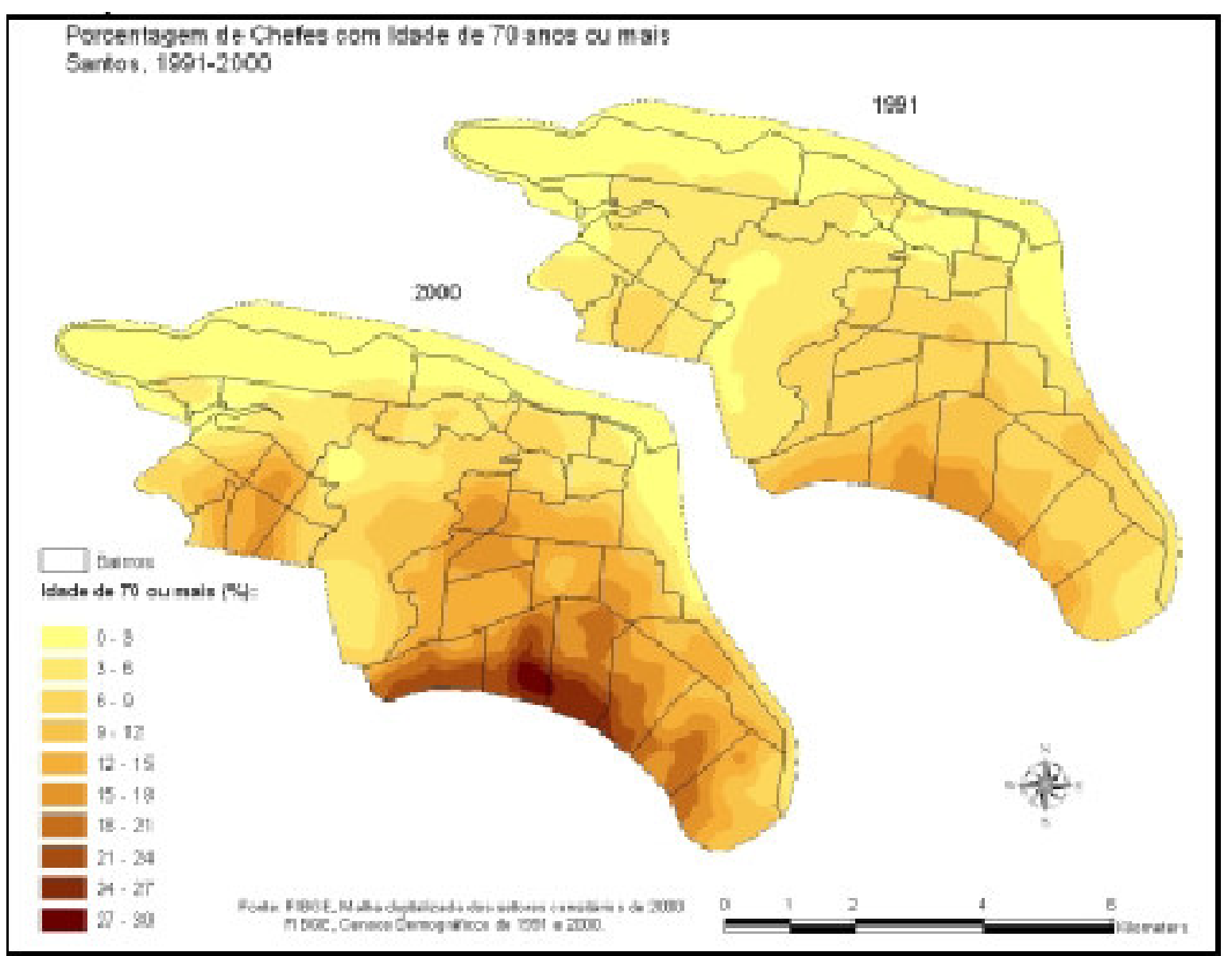

Figura 10: Porcentagens de chefes de domicilio com 70 anos ou mais em 1991 e 2000 de acordo com os Censos 1991 e 2000 do IBGE. Extraído de Jakob, 2003, p.118. 
Os chefes de domicílio das faixas etárias anteriores estão mais dispersos pela cidade. É interessante notar que a comparação entre os dois censos (1991 e 2000) em ambos os seguimentos etários (40 a 69 e a partir de 70 anos) mostra que a concentração de idosos na orla da praia é crescente.

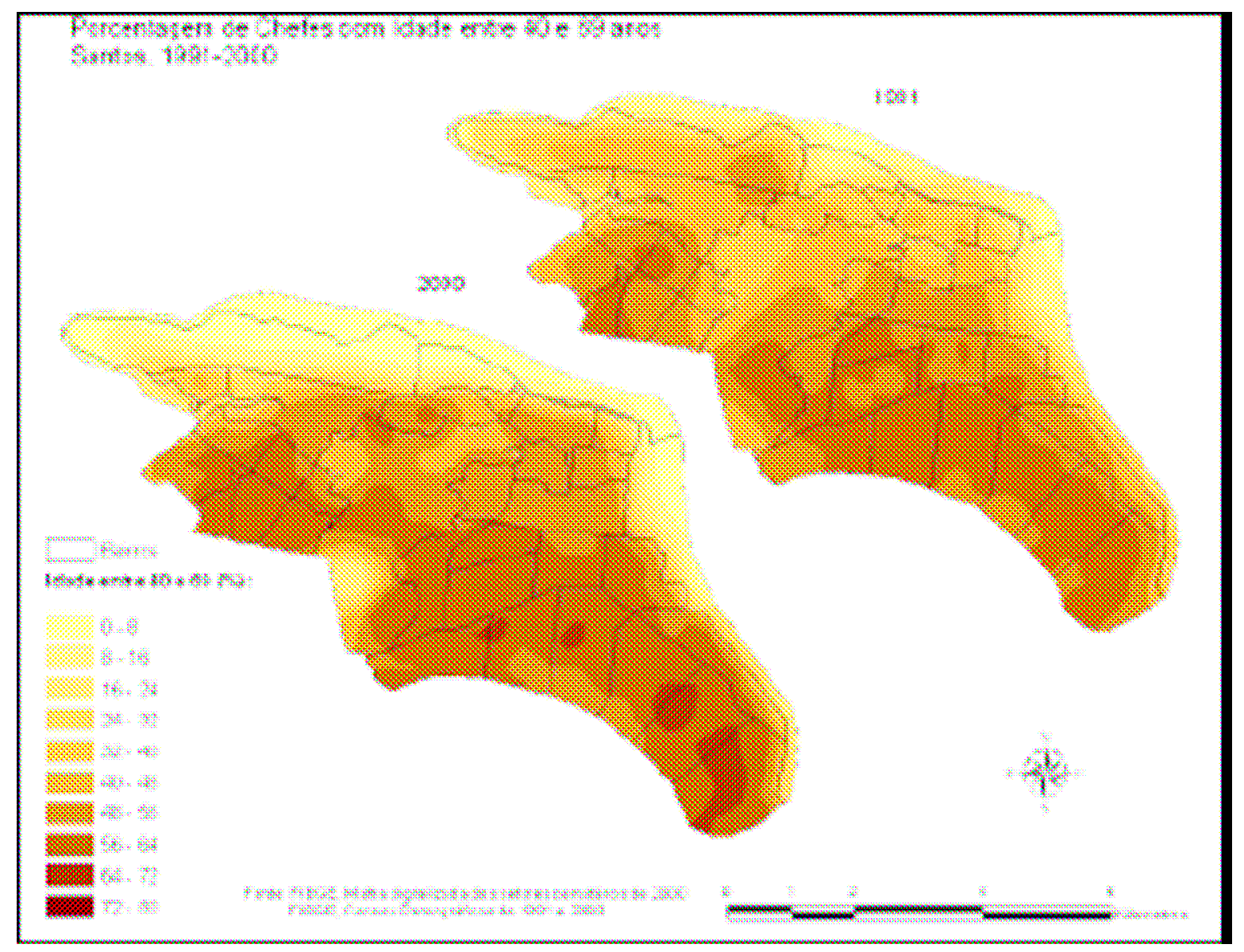

Figura 12: Porcentagem de chefes de domicílio entre 40 e 69 anos em Santos, de acordo com os Censos 1991 e 200 do IBGE. Extraído de Jakob, 2003, p. 117. 
Como vimos no capítulo 1, a maior parte da população idosa santista não é migrante: ou é natural ou está na cidade há muitos anos. Isso nos leva crer que há uma espécie de "migração intra-urbana" de uma população que residia na cidade em bairros "interiores" para a orla ou o mais próximo possível. $\mathrm{Na}$ fase em que percorremos a cidade fazendo entrevistas nas ruas, nas praças, na praia e nos pontos mais freqüentados pelos idosos, esses casos foram muito recorrentes, como contou Haroldo, freqüentador do SESC:

Juliana: Onde o senhor mora?

Haroldo: Bartolomeu de Gusmão. [avenida da orla da praia que começa no canal 5 e vai até a avenida portuária, na Ponta da Praia].

(...)

Juliana: O senhor sempre morou no mesmo endereço?

Haroldo: Não. Já morei no Macuco, no Campo Grande, na Encruzilhada, na Ponta da Praia e Aparecida, (...) sempre, procurando melhorar as condições de moradia. Hoje estou morando num apartamento de três dormitórios de frente para a praia.

(...)

Juliana: O Senhor é santista?

Haroldo: Sim.

E ainda o senhor João Ricardo, outro freqüentador do SESC:

Juliana: O senhor sempre morou em Santos?

João Ricardo: Não, eu morava em Minas e vim para cá em 1945.

Juliana: E senhor sempre morou neste mesmo endereço?

João Ricardo: Não.

J: Em qual foi o seu primeiro endereço?

João Ricardo: Tive várias mudanças, primeiro eu morei na Alfredo Shamas $n^{\circ} 7$, depois morei na Bernadino de Campos, 91 e depois onde eu vivi mais tempo foi na Av. Ana Costa, 414. 
Juliana: E aí por que o senhor. Veio para a Bartolomeu de Gusmão?

João Ricardo. Porque eu criei meus filhos nesta casa, uma casa muito grande, muito grande, eu acho, modéstia à parte, que era a casa mais bonita de Santos [que era na Ana Costa].

Juliana: Agora o senhor está na Bartolomeu de Gusmão?

João Ricardo: Na Bartolomeu de Gusmão, no apartamento.

Juliana: E por que o senhor decidiu ir pra lá?

João Ricardo: Porque eu pensei que não ia me acostumar em lugar nenhum, mas acontece que a vista para o mar me deixa enebriado! Me faz muito bem ver o mar.

Dentre o nosso universo de entrevistados, esse deslocamento apareceu mais para os bairros mais valorizados. Os idosos residentes nos bairros predominantemente de classe média (Campo Grande, Marapé, Vila Belmiro, Vila Matias, Encruzilhada) praticamente moraram sempre no mesmo bairro ou em imediações. Os que realizaram mais mudanças são os que estão residindo hoje na orla da praia ou próxima dela, como o Sr. Artur.:

Artur: Moro aqui perto, na Rua Firmino Barbosa.

Juliana: Perto da praia?

Artur: Não, a umas três quadras, entre o Sírio Libanez e o Tenis Clube [bairro Boqueirão].

Juliana: O senhor nasceu em Santos?

Artur: Nasci.

Juliana: E o senhor sempre morou nesse endereço?

Artur: Morei no Macuco até 72, com minha mãe na rua Nove. De 72 até 75 eu morei na Ponta da Praia com minha irmã, depois eu mudei pra o Marapé, depois morei na Osvaldo Cruz, no Boqueirão, e quando foi no fim de 75 por problemas políticos eu saí, fui pra Salvador, em 76 fiquei em Salvador, 77 voltei pra São Paulo e 
fiquei lá até 82 aí eu fui pra Europa, voltei em 83 e fui morar na Ponta da Praia. Depois fui comprar meu apartamento no Marapé e morei lá até 97, quando comprei casa em Águas de São Pedro, depois comprei um apartamento aqui no Boqueirão moro em Águas de São Pedro e em Santos.

Juliana: Por que o senhor escolheu morar aqui no Boqueirão?

Artur: Porque é um apartamento térreo, que já é uma grande vantagem, você mora perto do comercio, você mora perto do Gonzaga, que é o centro cultural da cidade, você mora perto de todo bom comércio, moro a um raio de uns $500 \mathrm{~m}$, moro perto do Carrefour, do Pão do Açúcar, a uns 800 m do Extra...

Já o Sr. Mourão, que encontramos numa pracinha do Campo Grande e foi "nascido e criado" em Santos, ficou sempre no mesmo bairro:

Mourão: Tem uns 15 anos que eu moro na Evaristo da Veiga.

Juliana: Perto do Canal 2? Sei onde é. E o senhor sempre morou lá?

Mourão: Depois que minha senhora faleceu, fez 15 anos.

Juliana: Antes morava onde?

Mourão: Morei na Espírito Santo, morei na Arnaldo de Carvalho que é ali perto...

Juliana: Sempre no mesmo bairro?

Mourão: Sim (...) Morava toda a família lá, desde 1920 eu e papai viemos pra o Campo Grande. Aqui era tudo mato, chácara de japonês ...

As tabulações do NESE-UNISANTA (cujos dados também estão representados em mapas) detalharam a importante diferenciação entre as duas faixas etárias idosas (de 60 até 80 anos e de 80 anos ou mais) na distribuição dos idosos pelos bairros da cidade e 
informaram a localização dos chefes de domicílio com renda acima de 20 salários mínimos. Nestes dados vemos que os bairros com mais renda têm maior proporção de idosos acima de 80 anos, enquanto os bairros de classe média, que seriam a zona urbana imediatamente atrás da zona de alta renda (Campo Grande, Marapé, Encruzilhada, Vila Matias, Vila Belmiro) concentram seus idosos mais na primeira faixa etária, sinalizando um envelhecimento mais recente. Até bairros da zona com menor renda (Zona Noroeste) já começam a ter maiores proporções de idosos (Castelo e Rádio Clube) do que outros bairros da Zona Leste como Vila Belmiro e Vila Matias, mas também entre o primeiro seguimento. Porém, chamam atenção os bairros Ponta da Praia e Gonzaga que corromperiam essa relação, pois são bairros com alta concentração de chefes de domicílio com renda acima de 20 salários mínimos, mas com uma população idosa mais jovem.

\begin{tabular}{|c|c|c|c|c|c|}
\hline Bairros & -60 a 64 & -65 a 69 & - 70 a 74 & -75 a 79 & - 80 ou mais \\
\hline Alemoa & 5 & 4 & 1 & 0 & 1 \\
\hline Aparecida & 2.007 & 1.890 & 1.371 & 895 & 781 \\
\hline Areia Branca & 244 & 209 & 192 & 119 & 98 \\
\hline Bom Retiro & 193 & 154 & 109 & 61 & 46 \\
\hline Boqueirão & 1.682 & 1.627 & 1.558 & 1.068 & 1.060 \\
\hline Campo Grande & 1.402 & 1.185 & 961 & 628 & 564 \\
\hline Caneleira & 56 & 50 & 47 & 31 & 22 \\
\hline Castelo & 553 & 426 & 254 & 155 & 106 \\
\hline Centro & 42 & 23 & 18 & 10 & 4 \\
\hline Chico de Paula & 67 & 50 & 22 & 13 & 13 \\
\hline Embaré & 1.850 & 1.688 & 1.504 & 973 & 1.007 \\
\hline Encruzilhada & 719 & 659 & 530 & 340 & 368 \\
\hline Estuário & 269 & 197 & 179 & 110 & 103 \\
\hline Gonzaga & 1.345 & 1.396 & 1.251 & 901 & 941 \\
\hline Jabaquara & 146 & 78 & 78 & 51 & 59 \\
\hline José Menino & 424 & 399 & 413 & 278 & 269 \\
\hline Macuco & 827 & 736 & 573 & 369 & 407 \\
\hline Marapé & 991 & 842 & 678 & 429 & 433 \\
\hline Monte Serrat & 28 & 18 & 16 & 9 & 6 \\
\hline Morro Cachoeira & 1 & 1 & 0 & 0 & 1 \\
\hline Morro Caneleira & 13 & 5 & 0 & 1 & 1 \\
\hline Morro Chico de Paula & 4 & 2 & 1 & 0 & 0 \\
\hline \multicolumn{6}{|l|}{ Morro Embaré (1) } \\
\hline Morro Fontana & 16 & 14 & 13 & 6 & 6 \\
\hline Morro Jabaquara & 43 & 31 & 28 & 17 & 13 \\
\hline Morro José Menino & 70 & 56 & 35 & 24 & 26 \\
\hline Morro Marapé & 40 & 44 & 21 & 14 & 10 \\
\hline
\end{tabular}




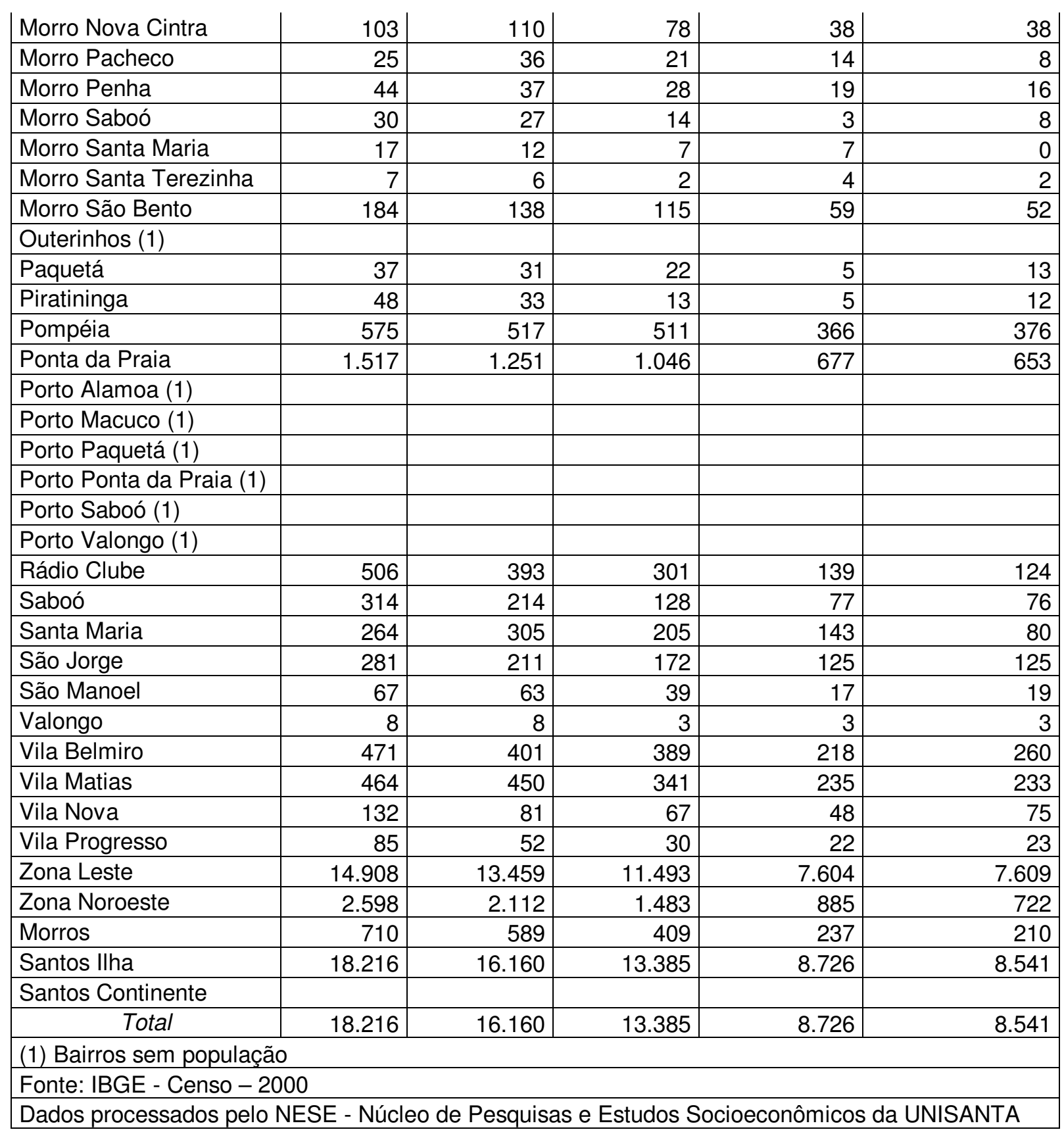




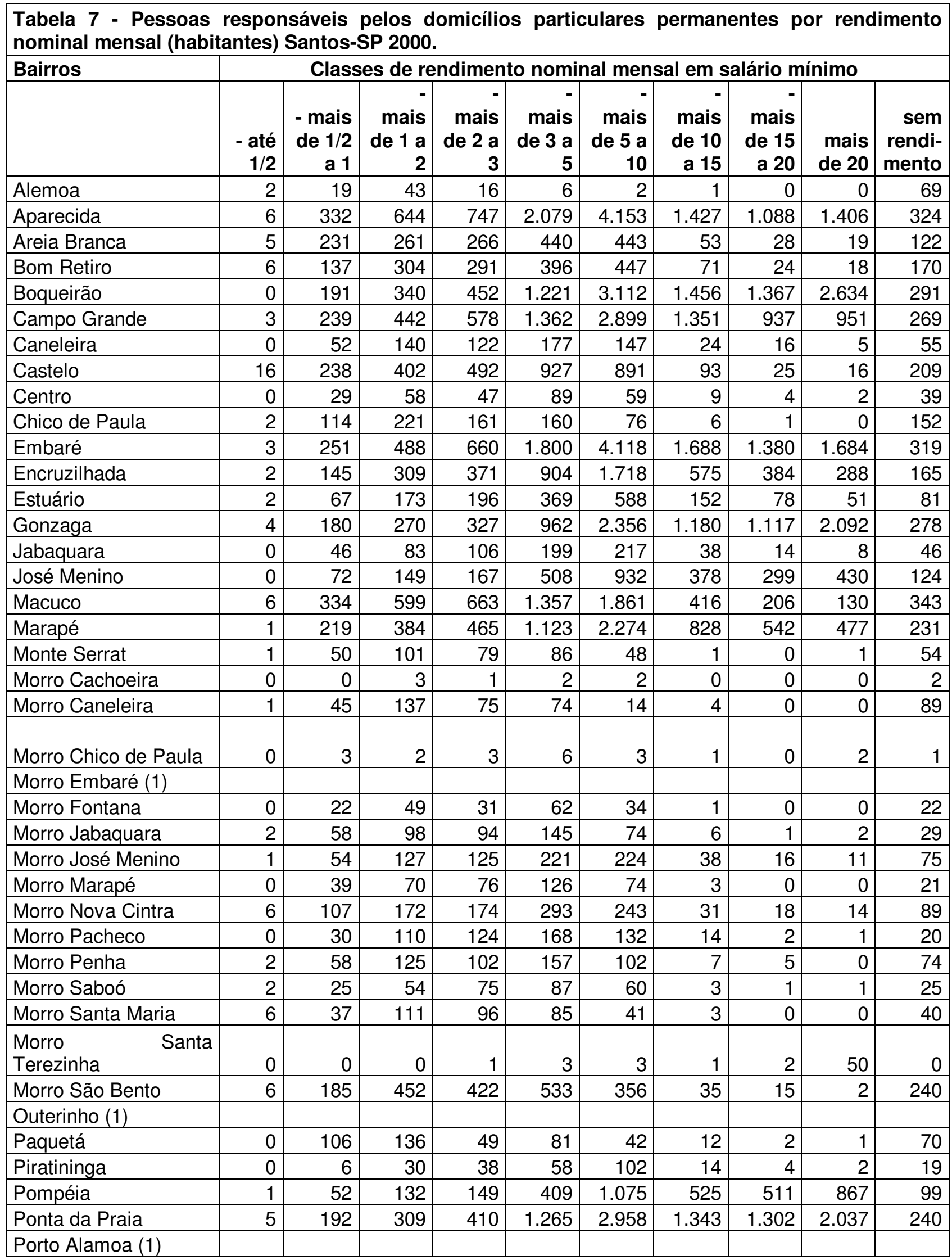




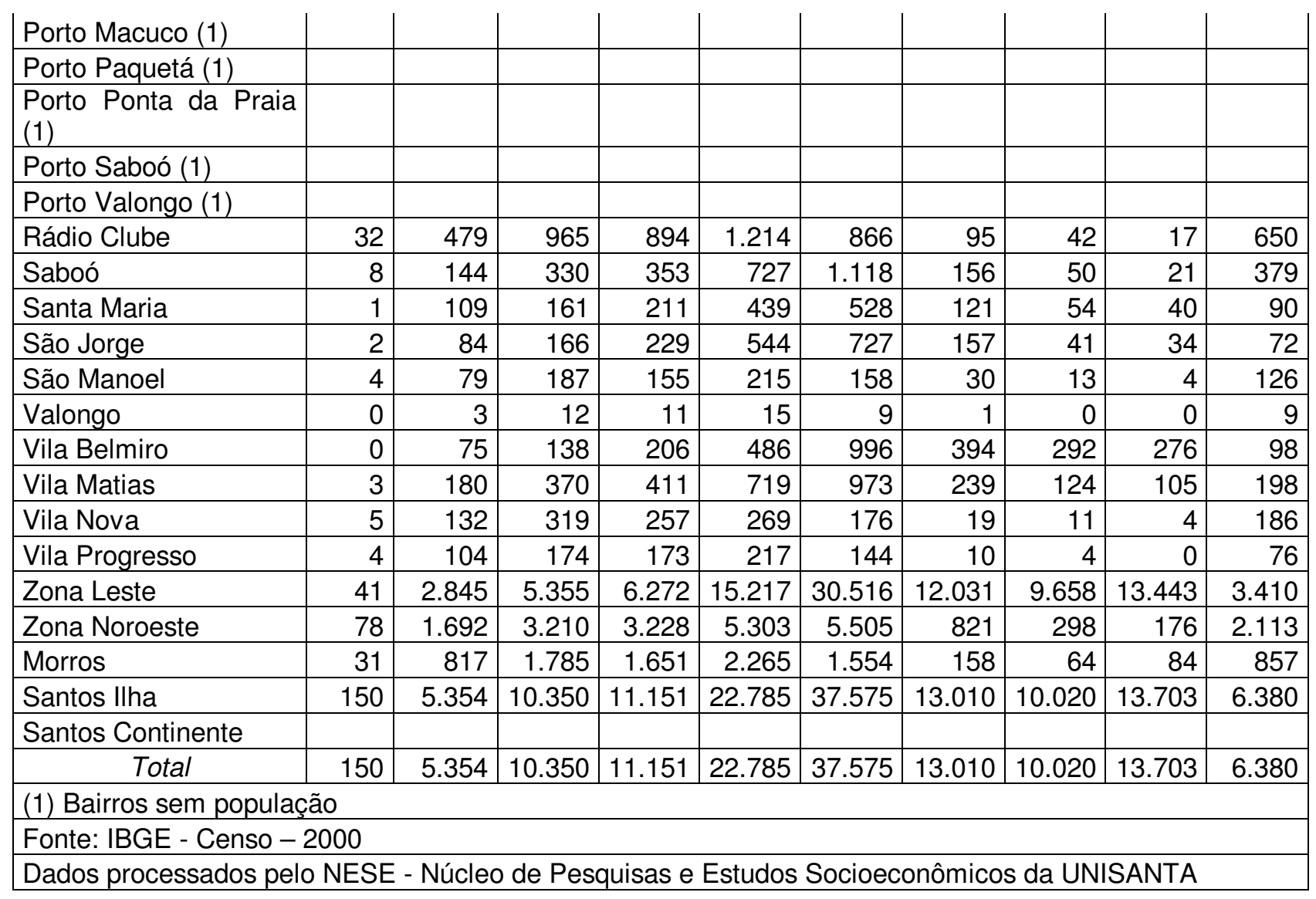




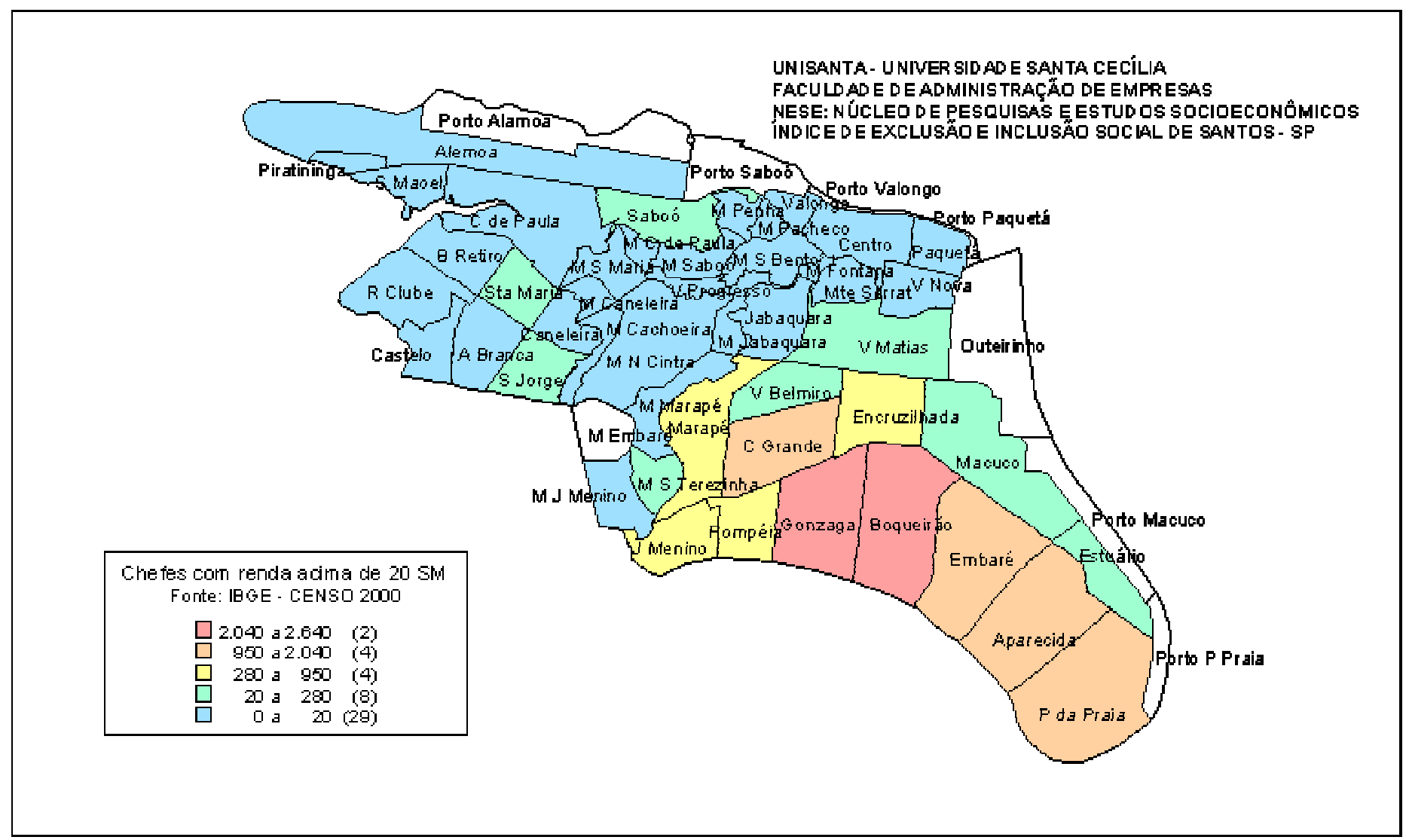

Mapa extraído de http://www.nese.unisanta.br em 20/08/2006. 
O bairro do Boqueirão é a tradicional área residencial de alta renda, enquanto o bairro da Ponta da Praia é, como vimos, o bairro que mais cresce em residências de luxo. O seguimento de 60 a 80 anos, é a faixa etária predominante dos idosos que se mudaram recentemente e da pequena parte que veio de outra cidade. Talvez aqui possamos assinalar que parte dos idosos migrantes estão preferindo esse bairro, sendo, portanto, parte da classe de alta renda que começa a ocupar a Ponta da Praia, mas para fazer essa afirmação categoricamente precisaríamos cruzar os dados relativos à renda nominal dos chefes de domicílio de cada setor censitário de Santos por idade, dados que não pudemos dispor nessa pesquisa.

O bairro do Gonzaga, o segundo com mais chefes de domicílio com renda acima de 20 salários mínimos, tem mais idosos entre os 60 e 64 anos do que nos outros intervalos etários. Foi um bairro bastante mencionado nas nossas entrevistas sobre mudança recente de residência, e pode estar sendo alvo preferido do deslocamento das residências de idosos. Nas entrevistas, ouvimos que morar no Gonzaga é melhor porque dá para "fazer tudo a pé" e está perto da praia e do "movimento". Foi a centralidade do Gonzaga, isto é, o fato de concentrar serviços e comércio variados atraindo consumidores de toda a cidade, sobretudo os da classe média, que apareceu como o fator decisivo pela escolha desse bairro para os entrevistados, alem do fato de ser um bairro residencial voltado para a praia.

A vida urbana das cidades turísticas pode ser um poderoso atrativo de camadas de renda média alta, principalmente da parte idosa dessa camada, que está procurando descanso, ao invés de bons negócios ou ascensão profissional. Na orla dessas cidades, e mais ainda de uma cidade que é um centro metropolitano, como Santos, é possível apreciar não só a paisagem como também as possibilidades de sociabilidade. Esse aspecto cosmopolita atraiu grande parte dos entrevistados, que afirmaram que uma das atividades que mais gostam na semana é ir passear no Gonzaga. Nesse sentido, conta como fator de atração de idosos “a dimensão cultural diferenciada das cidades litorâneas” da qual fala Villaça:

"O que mais chama a atenção não é tanto a mistura de classes sociais - que certamente existe - mas a mistura de funções urbanas e atividades. Os exíguos e os pequenos apartamentos expelem seus ocupantes para as ruas e praias, onde se desenvolve uma sociabilidade totalmente distinta da que ocorre nos bairros de 
apartamentos de São Paulo e Belo Horizonte. O clima favorece a vida ao ar livre, de maneira que as pessoas usam intensamente e transformam o espaço público e a sociabilidade" (1998:191).

Com as informações que tivemos na nossa pesquisa de campo e as tendências indicadas pelas tabelas acima, nos parece existir uma "migração intra-urbana" idosa para bairros da orla da praia, com ênfase nos bairros de alta renda. Pelas trajetórias residenciais narradas por alguns entrevistados, podemos considerar esse fenômeno como um processo de sucessão entre zonas urbanas movimentado pela população aposentada. É entre 55 e 60 anos predominantemente (de acordo com o que pudemos constatar nas entrevistas em localidades variadas) que acontece a aposentadoria e a mudança do arranjo familiar (quando os filhos deixam de morar com seus pais). Nessa fase então, esse senhores e senhoras que moravam em bairros mais interiores encontram o momento propício para buscar uma residência mais confortável, num ambiente (natural e construído) mais aprazível, e com menos despesa (um apartamento menor). Daí a busca pelos apartamentos outrora de segunda residência na praia.

Não cabe no escopo desse trabalho avaliar o peso da população idosa no mercado imobiliário, sendo essas apenas algumas indicações que se apresentaram na pesquisa. Nesse capítulo, nosso interesse foi identificar os processos que formaram (e ainda formam) a estrutura urbana de Santos, pois somente a partir dessa perspectiva acreditamos ser possível compreender como se deu o envelhecimento populacional.

\section{$* * *$}

Observamos que Santos teve diferentes direções de expansão urbana de acordo com o momento histórico que viveu produzindo configurações de estrutura urbana que revelavam os principais atores e processos sociais daquela sociedade de então. Podemos conceber uma primeira estrutura urbana como sendo a do pequeno núcleo urbano colonial, quando se formou a Vila de Santos, que veio até meados do século $\mathrm{XIX}^{60}$; uma segunda,

\footnotetext{
${ }^{60}$ O período colonial não foi examinado neste trabalho. Sobre isso, recomendamos os trabalhos de Andrade 1989 e 1981.
} 
quando Santos crescia dentro de si mesma limitada ainda às terras do que é hoje o centro antigo - a "cidade em transição", como chamou Lanna (1996). Esse segundo esquema estrutural veio até a primeira década do século XX, preparando-se para dar bases à estrutura urbana atual. A terceira e última configuração estrutural urbana, a nosso ver, é aquela que se forma com a forte entrada de migrantes e de população flutuante, resultando na urbanização completa (excetuando-se poucas áreas de mangues e morros) da Ilha de São Vicente, desde fins da primeira década do século XX até os nossos dias.

A partir da construção dos edifícios da orla da praia, com o adensamento da população nos bairros interiores, se consolidou a tendência de separação das classes sociais da estrutura urbana forjada no começo do século XX, pois houve uma substituição de classes sociais, como disse Araújo Filho (1965, p.38) ou, como diria Burgess, um processo de sucessão que partiu das cada vez mais degradadas terras do centro, e chegou ao limite geográfico: o mar. Isso acentuou a segregação residencial das classes pobres, pois, como demonstrou Jakob (2003) e Carriço (2002) a cidade cresceu mais para a direção dos bairros de menor infra-estrutura (Zona Noroeste e morros), e dos municípios vizinhos (Vicente de Carvalho, em Guarujá, São Vicente e Praia Grande). Nesse sentido, concordamos com Villaça, ao menos no que se refere a Santos, quando este autor argumenta que o padrão de estruturação das cidades brasileiras é a segregação espacial, pois até mesmo as leis de zoneamento da cidade - ao encarecer as exigências das construções na zona leste e tolerar os chalés nas áreas periféricas da cidade - incentivavam essa ordenação do espaço, como demonstrou Carriço, (2002).

A relação entre os processos estruturais globais e locais se fez sentir em Santos desde o seu nascimento, e até hoje seu estudo nos leva a considerar essa cidade como uma amostra que antecipa os fenômenos estruturais pelos quais o país em breve passará. Assim foi com o rompimento com o regime escravista e o início do regime republicano, segundo Olao Rodrigues (1980), arquitetados em grande parte em Santos; a imigração internacional, que passou primeiro por Santos; a industrialização, que foi intensa primeiro em Cubatão (na época pertencente a Santos), e nesse trabalho, vemos que assim também acontece com o envelhecimento populacional, que em Santos já atingiu níveis que só daqui a mais de uma década o país poderá vivenciar, de acordo com as atuais projeções demográficas. 
O estudo da bibliografia sobre a história de Santos, juntamente com a observação dos acontecimentos da cidade por meio dos jornais e de conversas com idosos santistas residentes há muitos anos nos mostrou que os processos estruturais nacionais foram decisivos para a formação de cidade de Santos, que foi por muitos anos a principal porta de entrada e saída de pessoas e mercadorias do Brasil. Dentre os principais fatores, destacamos:

1) $\mathrm{O}$ auge do comércio agro-exportador (café principalmente) e a construção do maior porto do país;

2) A instalação do Parque Industrial de Cubatão e do ABC, incentivados pela política varguista, pela política nacional desenvolvimentista de Juscelino Kubstchek e depois dos governos militares, gerando novo impulso migratório e nova formação de classe trabalhadora de baixa e média renda, tanto na cidade quanto em todo o estado de São Paulo, constituindo a população flutuante e aumentando o espaço urbano da RMBS.

3) A saturação do mercado da construção civil santista (que atendia à população flutuante mencionada no parágrafo anterior) e as grandes transformações econômicas mundiais que se fizeram sentir duramente através da política econômica neoliberal iniciada nos anos 1990, gerando as privatizações e demissões em massa dessas mesmas grandes indústrias da região que empregavam boa parte da classe média santista formada no período anterior (COSIPA, Ultrafértil, Telesp, Eletropaulo, etc.) e também da massa trabalhadora do Porto, reduzida pela introdução da conteinerização;

4) E hoje - queremos mostrar - o envelhecimento populacional, que em Santos é resultante do comportamento migratório das décadas anteriores e vem associado ao fenômeno demográfico da "onda jovem", conforme expusemos no capítulo 1.

Esses processos formaram a estrutura urbana sobre a qual incide o envelhecimento populacional de Santos. Formaram não só o espaço intra-urbano, com suas localizações 
intra-urbanas, suas áreas comerciais e residenciais, mas também a própria população idosa, que já foi população flutuante, classe operária, profissionais liberais, industriais, comerciantes e comerciários, estivadores, “doqueiros", “cosipanos”, "telespianos", professores, donas de casa, etc, que vivenciaram, sobretudo, o último momento de estruturação da cidade, na qual se consolidaram as áreas residenciais, tanto as centrais como as periféricas. O próximo capítulo trata então de examinar como agora, depois dos 60 anos, a população que construiu essa cidade - e também a que está chegando agora -utiliza e transforma o espaço intra-urbano de Santos. 


\title{
Capítulo 4: Envelhecendo na cidade: a produção das localizações urbanas de idosos.
}

\author{
“Alegria, para mim, é quando eu estou na rua!”. (Glória, 73 anos). \\ “Velho, se ficar dentro de casa, enferruja, não pode parar”. (Waldemar, 66 anos).
}

As localizações urbanas que caracterizam o espaço intra-urbano da cidade são reflexos dos processos que constituem a estrutura urbana, ou seja, decorrências dos movimentos da população para o trabalho e para o consumo (num sentido amplo: de serviços, de produtos, da paisagem natural, etc.), que são caracterizados, por sua vez, pelas condições sócio-econômicas, culturais e espaciais da população. Os idosos que têm autonomia física, como parte significativa da população santista, têm sua participação nesses deslocamentos, principalmente aqueles que participam das atividades lúdicas direcionadas ao público com mais de 60 anos que chamaremos pelo nome genérico de "atividades da terceira idade" ${ }^{\circ 1}$. O objetivo deste capítulo, portanto, é observar o cotidiano da população idosa santista caracterizada no primeiro capítulo desse trabalho e mostrar a produção das localizações urbanas de idosos.

Como vimos, a população idosa não é homogênea. É um grupo populacional crescente e mesmo que heterogêneo em si diferencia-se do restante da população. Somente o fato de não ter mais o trabalho tão presente em suas vidas (não constitui mais a maior parte do dia) já faz de grande parte desse grupo uma porção diferente.

Serão os aposentados uma classe social? A nosso ver, os idosos pertencem à mesma classe social que pertenciam quando trabalhavam, pois o envelhecimento é bastante diferenciado de acordo com as possibilidades de cada classe. A velhice não homogeneíza os indivíduos, diluindo essas diferenças de classe, como se pensava no começo dos estudos sobre velhice nas ciências sociais (cf. Debert 1999). Ao contrário, observamos que se

\footnotetext{
${ }^{61}$ Como veremos adiante, a maioria dos entrevistados resistem à expressão terceira idade para classificá-los num grupo social. Por outro lado, "terceira idade" e outras expressões equivalentes, como "melhor idade" e "idade da experiência" são utilizadas pelas instituições que promovem uma concepção de envelhecimento ativo e jovial através do oferecimento de programas, atividades, serviços e produtos para pessoas com mais de 60 anos. Queremos destacar neste capítulo que houve uma redefinição do tratamento dado a essa faixa etária devido às condições sociais específicas e recentes apontadas em grande parte no capítulo 1. "Terceira idade" não é um grupo social ou etário, mas uma forma de tratamento do envelhecimento - nem sempre acolhida pelos idosos.
} 
intensificam tais diferenças quanto ao acesso aos serviços e bens necessários para uma velhice "bem sucedida". Assim, há várias maneiras de envelhecer e de encarar esse período da vida, que recebe diferentes denominações deles próprios e da sociedade, de acordo com o que se quer ressaltar desse grupo (se são seus aspectos positivos de autonomia e realização pessoal, ou seu são seus aspectos negativos, de dependência e de gastos sociais) "Velhice", terceira idade, "melhor idade", "idade da experiência"; seja que nome for, é uma etapa (ou várias dentro de uma) que tem características próprias e gera um dia a dia urbano peculiar ${ }^{62}$.

A velhice é uma etapa da vida que vem sendo construída social e historicamente. É claro que o ponto de partida dessa idéia é o fato inegável do envelhecimento físico, mas as maneiras da sociedade lidar com esse fato biológico produzem, por sua vez, fatos sociais. Assim como sua condição social, a imagem e a idéia que o indivíduo idoso tem da velhice definem muito do seu cotidiano.

No caso de Santos, observamos que o modo como sua população idosa encara esse período define suas atividades cotidianas e a maneira como o idoso participa da cidade. Pode ser com a sua presença no espaço da cidade ao simplesmente passear em suas ruas, caminhar na praia ou no jardim; pode ser realizando deslocamentos para consumo indo a supermercados, padarias, bancos, restaurantes, academias de ginástica; ou simplesmente usufruindo as diversas possibilidades de sociabilidades que o espaço público proporciona, formando rodas de conversa, de carteado, grupos que se reúnem para tomar sol na praia, para dançar, ou apenas para constituir um grupo e formar um coletivo, pelo simples prazer de pertencer a uma coletividade, como sugeriu Simmel (1983), com o conceito de sociabilidade como sociação lúdica. Todas essas são atividades intra-urbanas; realizam-se porque há uma cidade que as acolhe, que dá o lugar para essa sociabilidade e que é, ao mesmo tempo, apropriada pelos idosos e ressignificada em algumas de suas localizações urbanas. Mas como se dá esse processo de apropriação, de ressignificação de um espaço público? Como as localizações urbanas se tornam conhecidas por serem freqüentadas por idosos? Ou antes, como se dá a produção da localização urbana?

\footnotetext{
${ }^{62}$ Não nos esquecemos dos muitos idosos e idosas vivendo na zona rural apesar de serem minoria, conforme Berquó e Baeninger (2000), mas acreditamos que as diversas denominações do envelhecimento é um fenômeno urbano, onde a pluralidade cultural cotidiana é manifesta e os grupos sócio-etários mais delimitados cotidianamente.
} 


\subsection{A produção das localizações urbanas}

Vimos no item 2.3 que, segundo Villaça (1998), a urbanização resulta de dois tipos de produtos espaciais: os objetos em si (edifícios, praças, shoppings, etc); e as localizações. A localização é a relação que um lugar tem com os demais e é também o valor de uso do espaço em termos de tempo e custo de deslocamento, isto é, em termos de acessibilidade. E esse segundo valor é produzido pelo tempo socialmente necessário para produzir a cidade inteira da qual aquela localização faz parte. Assim, a localização urbana é um valor de uso socialmente produzido do espaço urbano. Nas palavras de Villaça, "a localização ou ponto é o valor de uso produzido pelo trabalho coletivo dispendido na construção da cidade" (1998, p.74).

A localização intra-urbana ganha centralidade quando mostra capacidade de combinar socialmente fluxos de produção e consumo, concentrando, assim, destinos de deslocamentos de pessoas. Essa "capacidade de aglomerar", para usar a expressão de Lojkine (1981) que Villaça incorpora, é o valor específico da localização urbana. Ela é um espaço no qual é possível entrar em contato com os "efeitos úteis da aglomeração". Por aglomeração, Villaça refere-se à própria cidade: a existência da cidade como uma aglomeração organizada de pessoas é que produz as localizações urbanas. Assim, este autor vê no raciocínio de Lojkine (1981) a essência da produção social da localização:

"Um terceiro valor de uso do solo assume, a nosso ver, crescente importância com a socialização das condições gerais de produção: o que chamamos de capacidade de aglomerar, logo, de combinar socialmente meios de produção e de reprodução de uma formação social" (Lojkine 1981, p.163 in Villaça 1998, p.73).

Ao que Villaça explica:

“Isso a que Lojkine chama de 'capacidade de aglomerar' só é possível se existir essa formidável obra do trabalho humano que é a cidade, e especialmente seus sistemas de transporte. A terra urbana só interessa enquanto 'terra-localização' (Villaça, 1985,5), ou seja, enquanto meio de 
acesso a todo o sistema urbano da cidade”. (Villaça, 1998, p.74 [grifos nossos]).

A produção da localização urbana é especial não só por se tratar de uma relação, mas também porque é produzida coletivamente, por trabalho socialmente necessário coletivo de uma aglomeração socialmente produzida em cooperação: a própria cidade. Desde o seu primeiro texto sobre o assunto (Villaça, 1985), este autor vem tentando deslocar as conclusões de Marx, com devidas reservas, para pensar a terra urbana. Com base na teoria da produção do valor (tanto de uso quanto de troca), Villaça afirma que Marx considera $a$ cooperação como um outro tipo de força produtiva, que, além de potencializar o trabalho realizado, faz produtos que só ela pode fazer, como "carregar um móvel pesado", no qual não basta a soma dos trabalhos individuais, mas o trabalho de muitos em cooperação; e estabelece uma distinção entre "formas individuais [de cooperação] diretamente produzidas pelo capitalista [o empresário] ao nível da unidade produtiva e as formas sociais de cooperação". Villaça pretende ressaltar o papel da cooperação como "força produtiva social de trabalho social", sugerindo uma aplicação "recontextualizada" do conceito:

"Convém lembrar, a essa altura, que ao analisar a cooperação com vistas às aglomerações urbanas, não estamos tratando das condições gerais de produção freqüentemente a elas associadas. O que destacamos aqui é a força coletiva como um valor de uso específico das aglomerações em cooperação. A urbanização é uma força produtiva social desenvolvida através das aglomerações socialmente produzidas (ao contrário daquelas diretamente produzidas pelo capitalista) como condição para o desenvolvimento da cooperação, também no nível social (em oposição à cooperação diretamente produzida pelo capitalista)" (Villaça, 1998, p.76-77, [grifos nossos]).

Ou seja, ao dizer que as localizações urbanas são pontos significativos no espaço intra-urbano pela sua capacidade de aglomerar, Villaça não se refere a uma aglomeração de pessoas simplesmente, mas a aglomeração de funções urbanas.

Entretanto, o espaço representado por uma localização intra-urbana, ao concentrar destinos de deslocamentos de pessoas, ou seja, ao proporcionar o encontro de muitas pessoas, pode tornar-se também uma "localização social". Queremos acrescentar mais um 
sentido às localizações urbanas às quais Villaça atribui a caracterização da cidade e a diferenciação de um espaço intra-urbano de outro: o sentido de referencial social territorial na cidade. Quando utilizado freqüentemente por determinado grupo social, aquele "pedaço" ganha uma "fama": um significado social e simbólico. Consideramos que os territórios representativos na estrutura urbana devido às suas localizações urbanas, ou seja, aqueles que são acessíveis e concentram finalidades da cidade (consumo, serviços, lazer) são também referências sociais e simbólicas, que se definem pela sua relação com outras também. Na verdade, estamos sugerindo adicionar mais um sentido de centralidade à localização intraurbana: o social.

A partir dos relatos dos senhores e senhoras que conhecemos, soubemos que eles saem de casa com o objetivo de confraternizar e passar o tempo em conjunto com outras pessoas, de se constituir num grupo. Também vão buscar vínculos, amizades, inserção social, e por que não, prestígio. A sociabilidade que ali produzem, marca aquele local como um lugar de um tipo de prática social, e se torna uma referência. Isto ficará mais claro quando analisarmos mais adiante o circuito dos bailes de dança de salão, sobretudo no caso do Baile do Extra.

É verdade que Villaça está atento para o fato de que o conceito de cooperação não deve ser reduzido apenas à associação de trabalhadores na unidade de produção e tenta utilizar essa idéia na "esfera social", mas ainda dessa forma o autor não considera as dimensões culturais que lembramos aqui; não as incluem como fator fundamental na significação social da cidade. A cidade não deve ser tratada apenas como um conjunto de espaços, territórios, localizações, mas também como uma unidade de medida do social, uma forma material da própria estrutura social, com toda a sua cultura (ou culturas) incluída, como assinalou Park (1915) e tantos outros depois, como Sassen (2000), que ressalta essa dimensão cultural como uma das produtoras da globalidade nas metrópoles globais ${ }^{63}$.

Dentro do "combinado social” da localização o qual se refere Lojkine (1981), estão as práticas culturais, sociais, de lazer, que também levam os indivíduos a se deslocar. O

\footnotetext{
63 "It is not only the transmigration of capital that takes place in this global grid, but also people - both rich - the new transnacional, professional workforce, and poor, most migrant workers. And it is a space for the transmigration of cultural forms, the re-territorialization of 'local' subcultures" Sassen, 2000, p.151, [grifos nossos]).
} 
conjunto de pessoas que freqüenta a localização pode estar ali por motivos diversos e se constituir, assim, num grupo depois do encontro proporcionado pela comum acessibilidade ao local (como veremos nas rodas de conversa da praia), ou podem nem ao mesmo se constituir num grupo (apenas resultar numa grande circulação de pessoas, como num terminal de ônibus). Mas de uma forma ou de outra, caracterizam o local como lugar de alguma determinada presença ou atividade, de encontrar algum "tipo de gente". Como lembra Magnani (1996) "na realidade são as práticas sociais que dão significado ou ressignificam tais espaços, através de uma lógica que opera com muitos eixos de significação: casa/rua; masculino/feminino; sagrado/profano; público/privado; trabalho/lazer e assim por diante" (Magnani, 1996, p.39). Esses eixos são perfeitamente evidentes e delimitadores das práticas sociais que definem as localizações urbanas de idosos, como veremos na análise das nossas informações de campo.

Cremos que a reunião de pessoas e a sociabilidade ali produzida; as trocas (comerciais ou culturais), enfim, o encontro entre pessoas - como força de trabalho ou não adiciona um dado cultural à localização urbana, e conseqüentemente à cidade. É por isso também e não só pela sua participação no mercado imobiliário ou nas eleições municipais, que senhores e senhoras aposentados que não estão mais no processo de produção capitalista enquanto força de trabalho ou mesmo donas de casa que nunca foram parte do mercado de trabalho ${ }^{64}$ podem interferir na produção da cidade: como um grupo etário com identidade e cotidiano próprios ${ }^{65}$. Isso significa dizer que os cidadãos simplesmente enquanto citadinos que habitam ou circulam na cidade, dotam alguns espaços de uma centralidade social, embora subjetiva: o hipermercado Extra é uma referência central para o circuito dos idosos praticantes da dança de salão, mas não se constitui numa referência para o grupo de idosos do circuito dos corais ou das atividades de voluntariado, por exemplo.

Até aqui pudemos compreender que a localização urbana, tal como Villaça apresenta, se constitui de dois valores de uso:

\footnotetext{
${ }^{64}$ As donas de casa no trabalho cotidiano do lar também podem ser consideradas força de trabalho, mesmo que não estejam sendo remuneradas, pois estão dando o suporte para que outras pessoas de seu lar trabalhem "fora" remuneradamente. Nesse momento do texto queremos ressaltar somente que seus deslocamentos no espaço intra-urbano não são casa-trabalho, mas relacionados preponderantemente a consumo.

${ }^{65}$ Novamente devemos lembrar que este grupo etário não tem uma única identidade e um único cotidiano a ponto de igualar pobres e ricos. Mas é possível observar que dentro da parte idosa de cada estrato social há momentos do dia-a-dia em comum que faz dessa parte um grupo específico.
} 
1) Valor pela faculdade de estar acessível. Esse valor de uso é produzido pelo trabalho necessário para produzir a infra-estrutura que nela está e que leva as pessoas até ela.

2) Valor pela capacidade de combinar socialmente fluxos consumidores e produtores, que decorre em grande parte do que está assinalado no primeiro ponto, da acessibilidade e da centralidade do espaço na estrutura territorial urbana, da sua localização propriamente dita. É o valor de uso produzido pela aglomeração da qual fala Villaça.

3) Além desses aspectos, propomos incluir o da dimensão sócio-cultural da localização, pelo fato de ser uma referência social, portanto, simbólica, na cidade e de, por isso, classificar socialmente os lugares e os cidadãos.

Mas como se significa sócio-culturalmente o espaço da localização urbana? Cremos que pela presença frequiente de grupos sociais que conseguem ter acesso à localização e são atraídos pelas atividades urbanas que ela oferece. As características sociais e a sociabilidade dos freqüentadores do local formam o grupo e a própria localização urbana, caracterizando ambos. Por exemplo: que tipo de grupos sociais freqüentará um shopping center luxuoso? O que significa morar nos Jardins ou no Capão Redondo, em São Paulo? Morar no bairro da Caneleira ou no Boqueirão, em Santos? Que idéias estão relacionadas antecipadamente a uma pessoa que passa a maior parte da noite na Avenida General Câmara, em Santos? Ou na Avenida Amaral Gurgel, em São Paulo? Ou que passa o dia na Rua 25 de Março em São Paulo? Ou ainda que freqüenta os jardins da orla da praia de Santos às 10 horas da manhã de uma segunda-feira?

O espaço intra-urbano público está aparentemente aberto para a freqüência de quem quiser e por isso é impossível delimitar um grupo único de freqüentadores do local. No entanto, alguns grupos se apropriam daquele espaço público com a sua presença constante, constrangendo ou alternando com a presença de grupos diferentes, ou de indivíduos isolados - é o que pudemos examinar em algumas etnografias urbanas ${ }^{66}$. Essas apropriações privadas do espaço público acontecem em gradações variadas, mas definem um pouco da identidade

\footnotetext{
${ }^{66}$ Ver os estudos de Magnani (org) 1996, Frúgoli (1989) e Peixoto (2000).
} 
do grupo e do local, como mostrou Clarice Peixoto (2000) justamente sobre grupos de aposentados do Rio de Janeiro.

Vimos em Santos também, que os idosos aposentados por terem muito tempo livre e compartilharem, a maioria, de um ideal de envelhecimento jovializado, autônomo e ativo, prezam pela busca de encontros e de companhias de atividades. E o local de encontrar o novo, o fortuito, o inesperado, é, necessariamente, o inverso do mundo da casa (controlado, domesticado, íntimo, conhecido): o mundo da rua, como analisou Da Matta, (1985), ou simplesmente o mundo "semi-público" ou "semi-privado" (Peixoto 2000) de fora de casa, como veremos nas instituições que oferecem atividades para a terceira idade. Dessa forma, a busca pela sociabilidade que caracteriza as chamadas "Melhor Idade", "terceira idade", "Idade da Experiência" encontra na cidade o seu lugar. A terceira idade aparece como o "tipo ideal" de envelhecimento urbano.

Os estudos de antropologia urbana desenvolvidos por Magnani (1984, 1993 e 1996) procuraram investigar a rua como lugar de sociabilidade, pois o autor acredita que os elementos que constituem e caracterizam a sociabilidade tal como veremos adiante, estão possibilitados no espaço da rua:

"É a rua que resgata a experiência da diversidade, possibilitando a presença do forasteiro, o encontro entre desconhecidos, a troca entre diferentes, o reconhecimento dos semelhantes, a multiplicidade de usos e olhares - tudo num espaço público e regulado por normas também públicas" (Magnani, 1993, p. 46).

Seus estudos mostram, de maneira muito peculiar, a relação entre os espaços da cidade e grupos de pessoas que se reúnem para realizar uma mesma atividade. De maneira a identificar a dinâmica espacial desses grupos, o antropólogo criou um sistema de categorias que classifica e delimita abstratamente esses espaços.

Da menor para a maior, a primeira é a de "pedaço", que se refere ao espaço de vivência do indivíduo, onde ele costuma realizar a maior parte de suas atividades cotidianas, no qual circula a pé e encontra seus companheiros. Essa categoria foi pensada inicialmente 
para compreender o lazer nos bairros de periferia ${ }^{67}$, e diz respeito a uma dinâmica comunitária dos bairros "populares". Nesse sentido, a categoria "pedaço" revelava um sentimento de pertencimento local daquele que o freqüenta, além de outros laços:

"Entretanto, não bastava passar por esse lugar ou mesmo freqüentá-lo com alguma regularidade para 'ser do pedaço'; era preciso estar situado numa peculiar rede de relações que combina laços de parentesco, vizinhança, procedência, vínculos definidos por participação em atividades comunitárias e desportivas, etc.” (Magnani, 1993, p.49)

O autor estendeu essa categoria para o estudo do centro da cidade, definindo "pedaços centrais": pequenas áreas caracterizadas por comércio e serviços voltados para um tipo específico de público que se encontra lá não só para consumi-lo, mas também para confraternizar e encontrar seus pares. Como as galerias de rock no centro de São Paulo e as lojas de discos e cds de "black music" que concentram adeptos do hip hop. O pedaço seria o espaço de vivência e sociabilidade desse grupo.

Essa categoria de "pedaços centrais" nos lembra a de "regiões morais" proposta por Park (1915), sobretudo quando Magnani assinala que, diferente do pedaço dos bairros populares, os frequientadores dos pedaços centrais nem sempre se conhecem. Park (1915) sugeriu a existência de áreas naturais na cidade que concentravam atividades de lazer específicas para freqüentadores assíduos, nas quais se reuniam aqueles que tinham gostos e diversões comuns, como podemos ver hoje a Vila Madalena ou o Bexiga; mas eram áreas nas quais predominavam os contatos secundários ${ }^{68}$. No pedaço central

“os freqüentadores não necessariamente se conhecem - ao menos não por intermédio de vínculos construídos no dia-a-dia do bairro - mas sim se reconhecem enquanto portadores dos mesmos símbolos que remetem a

\footnotetext{
${ }^{67}$ A delimitação da área caracterizada como pedaço não inclui necessariamente o local do trabalho, que pode ser numa área industrial ou numa área mais central, distante desses bairros populares, geralmente periféricos.

${ }^{68} \mathrm{O}$ conceito de contato secundário, assim como o seu oposto, o de contato primário, foi forjado por Cooley para caracterizar a sociabilidade nas cidades modernas americanas. Para esse sociólogo da Escola de Chicago, na vida urbana proliferam-se os contatos secundários, que são contatos comunicativos passageiros e impessoais entre indivíduos, e diminuem os contatos primários, que são pessoais, podendo reincidir entre os mesmos indivíduos, como é o contato entre familiares.
} 
gostos, orientações, valores, hábitos de consumo, modos de vida semelhantes" (Magnani, 2001, p.39).

Ambas as categorias - pedaço central e região moral - nos servem para assinalar que a prática da sociabilidade como um fim em si mesmo pode caracterizar áreas da cidade ${ }^{69}$. Mas, a nosso ver, o interesse do autor não está nos efeitos dessa sociabilidade no espaço da cidade enquanto um todo estruturado, mas na cultura que se constrói entre o indivíduo e o "pedaço". A categoria pedaço foi criada para captar

“(...) aquele espaço intermediário entre o privado (a casa) e o público, onde se desenvolve uma sociabilidade básica, mais ampla que a fundada nos laços familiares, porém mais densa, significativa e estável que as relações formais e individualizadas impostas pela sociedade” (Magnani 1984, p.138 in Magnani 1993, p.49 [grifos nossos]).

Por isso, é diferente de "localização intra-urbana" no sentido que queremos dar a esse termo. A categoria "pedaço" não conjuga os atributos estruturais conferidos pelo seu posicionamento (territorial e social) dentro da estrutura urbana; não realça o valor daquele espaço em termos de acessibilidade (em tempo e custo) - o próprio "valor localização". Está mais associada à categoria de "vizinhança" enquanto comunidade de convívio íntimo local.

Além de "pedaço", Magnani criou outras categorias para apreender a espacialidade da cultura urbana: manchas, circuitos e trajetos. As manchas concentram serviços e comércios relacionados a uma determinada atividade. São maiores e diferentes da categoria pedaço, que se refere a espaços delimitados pelas práticas de um grupo ou pelo espaço de vivência de um grupo de indivíduos. As manchas comportam um número mais diversificado de freqüentadores e de equipamentos urbanos, podem conter vários pedaços e não se restringem ao lazer.

\footnotetext{
${ }^{69}$ A similaridade de significados entre algumas categorias que se referem ao espaço de dentro da cidade assinala, a nosso ver, um ponto de convergência entre esses estudos de disciplinas diversas: o da necessidade de focar o olhar na interação das pessoas com os espaços, de maneira a compreender como a cidade é organizada por essa interação, e não somente pelos movimentos dos setores residenciais da classe de alta renda, ou pelos movimentos do mercado imobiliário, ou ainda, pela definição das vias de transporte. Apesar da crescente segregação residencial que já acontece nas cidades médias brasileiras (como mostrou Rodrigues, (2005) para o oeste paulista), a circulação de pessoas e essas interações urbanas captadas pelas etnografias recentes (Peixoto, 2000, Frúgoli 1989, Magnani, 1996) persistem como processo caracterizador dos espaços.
} 
Os trajetos são os possíveis deslocamentos entre manchas ou entre pedaços, sendo uma forma de uso do espaço diferente daquela evocada pela categoria "pedaço"; Enquanto esta, como foi visto, remete a um território que funciona como ponto de referência - e, no caso da vida no bairro, evoca a permanência de laços de família, de vizinhança, origem e outros - trajeto aplica-se a fluxos no espaço mais abrangente da cidade e no interior das manchas urbanas" (Magnani, 1996, p.40). Os trajetos ligam pontos dentro de uma mancha, ou ligam pedaços. Pode ser as possíveis sequiências de locais que se pode visitar numa mancha, como na mancha de lazer do bairro do Bexiga, onde se costuma ir a uma livraria, depois a um café e depois a uma cantina; ou ainda: começar pela cantina, ir depois a uma casa de shows, e finalizar com o café, e assim por diante. Os trajetos mostram que os

pedaços não são espaços fechados e impermeáveis, onde só a vida comunitária acontece: "É a noção de trajeto que abre o pedaço para fora, para o espaço e âmbito do público" (Magnani, 1996, p.46).

Há ainda os circuitos, que "unem estabelecimentos caracterizados pelo exercício de determinada prática ou oferta de determinado serviço, porém não contíguos na paisagem urbana, sendo reconhecidos em sua totalidade apenas pelos usuários: circuito gay, circuito dos cines de arte, circuito esotérico, dos salões de dança e shows black, circuito do povode-santo, dos antiquários, brechós, clubes e outros" (Magnani, 1996, p.45). Dessa forma, os circuitos são praticados por indivíduos que têm algo em comum e podem formar grupos, mas cujos pontos de encontro não se concentram num pedaço.

Os idosos santistas também vivenciam a cidade por meio de circuitos. Há um grupo de idosos que assiduamente freqüenta bailes pela cidade, cumprindo uma agenda semanal. Esses bailes acontecem em espaços públicos, marcando localizações urbanas de idosos, como veremos.

Assim, as categorias de pedaço, mancha, trajeto e circuito podem nos ajudar a perceber os usos da cidade, embora, a nosso ver, seja a noção de localização urbana que nos permite recuperar a característica fundamental dos espaços eleitos pelos idosos na cidade: a sua relativa acessibilidade e centralidade, compreendendo-os inseridos numa estrutura urbana. Durante a pesquisa nosso foco no estudo da localização intra-urbana teve que se desviar da hipótese de influência das localizações urbanas de idosos no 
desenvolvimento da estrutura urbana. A circulação dos idosos de Santos não se demonstrou grande o suficiente para criar localizações urbanas representativas estruturalmente para toda cidade; no entanto, observamos efetivamente que os locais eleitos por eles para permanecerem, se reunirem ou praticarem alguma atividade tinham uma grande acessibilidade comum a todos, e possibilitavam, por isso, a formação de grupos que caracterizavam e marcavam socialmente aquele ponto da cidade. Por isso não se trata apenas de pedaços centrais, mas também de localizações urbanas que foram adotadas por idosos, dando a possibilidade de inscrição de um novo dado na cultura urbana, na imagem da cidade.

O espaço atua como local de sociabilidade e ele próprio produz o grupo que o caracterizará como localização urbana. A nosso ver, esse é o caso de alguns grupos de idosos em Santos. É verdade que já havia uma pré-disposição das pessoas idosas as constituir um grupo; o desejo de ser parte de um grupo veio antecipadamente, mas a concretização do grupo, a "turma", só se dá no espaço descoberto. Entre as atividades cotidianas dos idosos aposentados, observamos que a sociabilidade como um fim em si mesma está muito presente, o que os coloca como um grupo importante na caracterização sócio-cultural de certas localizações urbanas, principalmente as que estão próximas das suas áreas residenciais. Para aqueles aposentados, sobretudo aos que não trabalham mais, o espaço público da cidade, a rua, a avenida da praia, não é um lugar só de passagem, que está entre o ponto de partida e o de chegada: é um lugar também de passar o tempo. As localizações urbanas, os espaços-localizações oferecem umas das condições do encontro, da sociabilidade: um espaço determinado e acessível. A produção dialética espaço-sociedade se concretiza na localização, pois se a localização classifica os cidadãos, e os faz valer pelo lugar onde estão, esses, em interação, reafirmam os significados sociais, culturais e simbólicos da localização.

É cada vez maior a parte dos idosos santistas que vêm transformando a velhice num período de conhecer o novo, de formar novos vínculos, de estar fora de casa, em contraposição a uma idéia cada vez mais "velha" de velhice recatada e introspectiva. Nesse "novo modo de envelhecer" é central a sociabilidade, uma forma sociológica bastante peculiar que mereceu a atenção de Simmel na sua busca da essência da sociedade moderna. 
A universalização da aposentadoria e a conseqüente melhoria das condições sociais da população idosa começam a dar alguma base para a busca do envelhecimento digno. Entre aqueles que puderam chegar a essa fase da vida com autonomia física e certa autonomia financeira (não só as camadas médias, mas também os pobres não miseráveis), por meio da sociabilidade na cidade, a velhice se refaz.

\subsection{A Sociabilidade e a aposentadoria}

A sociabilidade é definida sociologicamente por Simmel como uma forma autônoma de sociação lúdica. A sociação é a interação na qual os indivíduos "se agrupam em unidades que satisfazem seus interesses". Quando a sociação se torna um fim em si mesma, aí está a sociabilidade. A sociedade, para Simmel, é formada por esses agrupamentos; constitui-se quando os conteúdos dos indivíduos (seus desejos, propósitos, ou ambos) entram em contato uns com os outros por meio de formas sociais, como a interação ou como a sociação. A sociedade (a reunião dos conteúdos por meio das formas sociais) se constitui, portanto, por meio de sociações.

No entanto, os conteúdos associados às formas adquirem autonomia e tornam-se fins em si mesmos. Um dos exemplos de Simmel é a ciência. Antes, era um conhecimento construído para facilitar a vida humana. Com o seu desenvolvimento, tornou-se um valor em si mesma, ou, como diria Weber, mais uma esfera de valor. Hoje podemos dizer que tal ou qual coisa tem seu valor "científico". Assim também a arte. "Completamente estabelecida, [explica Simmel], é inteiramente separada da vida" (Simmel, 1983, p. 167).

A noção de sociabilidade resulta do jogo entre a determinação da forma pelos conteúdos a serem expressos, e da determinação dos conteúdos (reduzidos de importância) pelas formas que querem se expressar, ou seja: resulta da autonomia da forma sociação. A conversa pela conversa, e não para transmitir informações. A sociabilidade é uma forma de interação que se tornou estímulo, um conteúdo do jogo de interações entre indivíduos, assim "como a caça, o ganho ardiloso, a prova de força física e intelectual, a competição, etc.", tornam-se objetivos em si mesmos, ao invés do produto dessas ações (Simmel, p.168). Assim, a definição de sociabilidade de Simmel, é a de "fenômeno de liberação das formas de todos os laços com os conteúdos", existindo por si mesmas, "pelo fascínio que difundem 
pela própria liberação desses laços” (Simmel, 1983, p.168). Daí a definição sociológica de sociabilidade como forma autônoma ou lúdica de sociação.

Dessa forma, a sociabilidade verdadeira não visa nenhum produto. "As verdadeiras motivações da sociação, condicionadas pela vida, não têm importância para a sociabilidade" (p.169). O resultado desse fenômeno, de processo interacional, "são exclusivamente as pessoas que se encontram numa reunião social". Por isso que a sociabilidade tem importância, a nosso ver, como processo social urbano: forma os grupos que caracterizarão, e se deterão em espaços intra-urbanos, ao invés de simplesmente passarem por eles, com destino a outro lugar.

Uma característica fundamental para Simmel, para haver sociabilidade é a livre interação e a equivalência de elementos. Para ocorrer, a sociabilidade precisa de condições "democráticas", deve ocorrer entre iguais ou, melhor dizendo, entre iguais na dada situação. E essa equivalência, muitas vezes construída para o momento, gera um ambiente ideal, um mundo sem os conflitos latentes do mundo real. Por isso Simmel argumenta que a sociabilidade não deve ocorrer entre indivíduos de classes sociais muito diferentes, sob pena de dolorosas e frustrantes experiências. Como o alvo da sociabilidade é apenas "o sucesso do momento sociável e, quando muito, da lembrança dele", não é permitido usar de atributos externos no jogo: "riqueza, posição social, cultura, fama, méritos e capacidades excepcionais não podem representar qualquer papel na sociabilidade", sob pena de se diferenciar e romper com a sua condição de estar no grupo: "Sem a redução da autonomia e da exacerbação pessoal - que é efetuado por essa forma - a própria reunião não seria possível" (p.170).

É preciso haver alguma condição de igualdade, algo em comum entre os indivíduos, para ser gerada a sociabilidade. No caso dos idosos, a fase da vida em que estão é essa condição. Não só a idade, mas também a aposentadoria, a redução dos papéis sociais (sobretudo a ausência do papel de agente produtivo) é que os torna "marinheiros do mesmo barco". No caso específico dos idosos, são também esses os mesmos motivos, que os fazem procurar a sociação: associar-se a um outro grupo e ganhar um papel numa nova cena.

A necessidade de uma condição comum entre os membros da sociabilidade colocada por Simmel pode explicar a grande predominância da interação intra-geracional entre os 
idosos, embora eles tenham resistência a ser identificados como pessoas da terceira idade, da "melhor idade", etc, preferindo muitas vezes o termo "idoso" por este ser mais genérico. Os idosos entrevistados no espaço da rua buscavam, a nosso ver, um lugar onde pudessem ver pessoas de outras idades. Preferiam a rua, a praia, as praças, o Gonzaga ${ }^{70}$, e não outros lugares com atividades de terceira idade. Entretanto, o que observamos é que quando a sociabilidade acontece, ou seja, quando o encontro gera alguma comunicação, é entre quase iguais que ele se dá, e sua duração, continuidade e permanência no mesmo espaço caracterizam as localizações urbanas de idosos.

Outra condição da sociabilidade que a torna muito atraente para eles é o constrangimento às diferenciações de classe, que pelo menos naquele momento podem ser esquecidas. Quando estão fora de casa os problemas financeiros, a casa pequena, a dependência dos filhos, tudo isso fica em casa. Veremos adiante que poder sair de casa-e efetivamente fazê-lo - é visto por muitos idosos como o segredo de um envelhecimento bem vivido.

A sociabilidade deve ter algo de casual, e ser momentânea, com tempo e espaço determinados e limitados. Quando a sociabilidade é o objetivo declarado, como nas instituições de promoção de convivência da Prefeitura, ou como em alguns eventos do SESC, esses grupos são recusados e estigmatizados por outros idosos. A predominância das formas sobre o conteúdo resulta muitas vezes numa falta de relação objetiva com a realidade, e essa falta de "utilidade", de "aplicação" é estigmatizada por aqueles que estão fora do jogo da sociabilidade. Afinal a sociabilidade "se poupa dos atritos com a realidade por meio de uma relação meramente formal com essa”. (Simmel, 1983, p.169). Entre os idosos que rejeitaram e estigmatizaram as atividades lúdicas da terceira idade e as próprias pracinhas de jogos estão principalmente homens que ainda trabalham e aqueles que tentam afirmar um papel social dentro da família, do lar. Por outro lado, os entrevistados nos bailes contaram que não tinham mais "tarefas": os filhos e os netos já estão criados. Ou não tinham nem filhos e nem netos.

No entanto, a "utilidade" dos encontros diários, por mais "fúteis" que possam parecer, existe e é o próprio encontro, como refletiu Simmel: “Os sociados sentem que a

\footnotetext{
${ }^{70}$ Bairro de Santos. Ver o terceiro capítulo.
} 
formação de uma sociedade como tal é um valor; são impelidos para essa forma de existência" (p.168). Novamente para os idosos isso é mais tocante, pois eles vêem reduzida sua participação em outros coletivos como o da família ${ }^{71}$, e perderam, em geral, o mundo do trabalho.

É grande e plural a população idosa que se vê nas ruas, mas é possível, perceber entre ela grupos, turmas, que se reúnem em certos locais. Esses idosos, de maneiras diversas, estão ressignificando localizações intra-urbanas, que vamos chamar simplesmente de localizações urbanas de idosos. Mas antes de entrar no exame dessas experiências urbanas, a nosso ver bastante influenciadas pela terceira idade enquanto representação social de envelhecimento proposta pelas instituições que se voltaram a uma clientela idosa e abraçada pela mídia e pelo mercado, é preciso, ao menos em linhas gerais, revisar como o envelhecimento se tornou um assunto social.

\subsection{Alguns aspectos sociais da velhice}

A socialização da velhice é um processo contínuo que hoje renova suas características, mas que vem desde a segunda metade do século XIX (Lenoir, 1979). Nesse século foram criadas as grandes invenções tecnológicas que transformaram a noção de tempo e espaço (como a energia elétrica, a locomotiva a vapor), consolidou-se o modo de vida moderno em oposição ao tradicional (Ortiz, 1991) e se difundiu quase mundialmente o sistema capitalista industrial. Desde essas décadas em que se inicia o uso da ciência como principal solução aos "recém identificados" problemas sociais (como foi, por exemplo, com a loucura), a velhice vem gradualmente migrando da esfera privada para a esfera pública também sendo tratada como um problema social. Assim, na segunda metade daquele século nas sociedades ocidentais capitalistas consolidava-se a visão que permanece ainda hoje no senso comum de que a velhice é uma etapa da vida caracterizada pela decadência física e ausência de papéis sociais (Lenoir, 1979). E desde então, os velhos foram marginalizados por não poderem mais vender a sua força de trabalho e considerados inaproveitáveis para a

\footnotetext{
${ }^{71}$ A participação na família e no lar é muito variada dentro das classes sociais. Como já vimos no primeiro capítulo, há muitos idosos de renda baixa que permanecem por muitos anos como chefes de domicílio, com até mais de uma família (a sua e a dos filhos). Já entre os idosos de renda média ou maior, foi mais freqüente nas nossas entrevistas encontrar aqueles que moravam sozinhos ou na casa dos filhos.
} 
sociedade, como um fardo a ser sustentado por ela, como bem demonstraram Bosi (1987), Beauvoir (1976), Pacheco (2004), Goldman (2004), entre outros. Contudo, a mesma condição que os marginalizou, conferiu a eles, o status de um grupo social que deveria ser recompensado e amparado, como assinalou Lenoir (1979) e Debert:

“o avanço da idade como processo contínuo de perdas e dependência, dando aos idosos uma identidade de condições, sendo responsável por um conjunto de imagens negativas associadas à velhice, é também um elemento fundamental para a legitimação de direitos sociais, como a universalização da aposentadoria” (Debert, 1999, p.14).

Assim, o envelhecimento do corpo foi (e é) uma característica fundamental, inegável, distintiva e classificatória dos indivíduos, sendo esse o ponto de partida para pensar todas as implicações do envelhecimento nos indivíduos e na sociedade. (Featherstone, 1998).

O direito à aposentadoria, para fazer descansar os corpos que foram explorados (e envelhecidos precocemente muitas vezes) durante toda uma vida de trabalho é a legitimação oficial de um período de inatividade e passa a ser mais um marcador da condição de velho, além dos fatores mais evidentes da decadência física e da relativa perda da capacidade produtiva. A introdução da aposentadoria trouxe também uma melhora nas condições econômicas da população idosa, que antes era um dos estratos mais pobres da sociedade capitalista como um todo.

Essas mudanças se refletiram no modo de tratamento dessa população: de "velhos" passaram a "idosos", uma denominação que, segundo Peixoto (2000), foi empregada para abrandar a carga negativa do termo "velho", que se referia a pessoas improdutivas e de classes baixas. Ainda assim, a aposentadoria não retira a feição negativa da experiência da velhice, pois "simboliza a perda de um papel social fundamental - o de indivíduo produtivo - passando a ser sintoma social de envelhecimento" (Peixoto, 2000:81).

Jaime Pacheco (2004) parece concordar com essa afirmação, pois para ele o trabalho marca o ciclo de vida nas sociedades ocidentais, que é formado em grande parte pela presença de instituições sociais. Quando velho, o indivíduo não é mais considerado útil para o trabalho, e a velhice passa a ser fonte de sofrimento. A lógica desse processo vem desde a escola, com a imposição de hábitos de disciplina e serviço, como uma "reprodução 
antecipada da empresa", um treino para o mercado. Os modos de organização do trabalho (taylorista, fordista, pós-fordista e neotaylorista), que desapropriam do trabalhador o ato da criação, persuadem o trabalhador envelhecido a dar o seu lugar para outro mais jovem, supostamente mais capacitado, isto é, que possa seguir com mais eficiência as regras e padrões impostos. Esse pensamento de que o indivíduo velho deve se retirar permeia a sociedade e também os estudos mais influentes sobre o trabalhador idoso e a sociedade industrial, como Cumming e Henry (1961) e Cowgill e Holmes, (1972). Nesse sentido, "a aposentadoria, como parte do processo de desengajamento, apresenta aos trabalhadores o tempo livre como recompensa. Mas, também, expõe a contradição do mundo ocidental na valorização do ser humano" (Pacheco, 2004, p.219).

Além disso - e talvez principalmente - a nosso ver a saída do mundo do trabalho é a perda de um universo de relações sociais, de uma das instâncias que definiam a própria identidade pessoal do trabalhador, sobretudo no caso dos homens, já que as mulheres idosas participaram menos do mercado de trabalho. A aposentadoria marca essa troca de papel social: de trabalhador a aposentado.

Aurélio, (74 anos, morador do Marapé): Fiquei na saudade de lá do ambiente que eu vivia, da companheirada e coisa e tal. Hoje a gente vê as Docas do jeito que está, dá até uma tristeza na gente...

A aposentadoria tira o compromisso de ir trabalhar todos os dias, mas não o senso de dever, de querer ser útil para sociedade. A passagem de uma identidade a outra (de trabalhador a aposentado) não é fácil e nem imediata, pois muitos viveram até então trabalhando desde a infância, e a noção de existência produtiva é a única que conhecem: “quem não vive para servir, não serve para viver". Muitos dos idosos entrevistados nas pracinhas estavam aposentados há mais de vinte anos, mas apenas há cinco, há sete, há três anos que as frequientavam. Para alguns aposentados recentemente, e principalmente para aqueles que sempre trabalharam desde cedo, caracterizá-los como terceira idade e propor a eles um envelhecimento lúdico, não faz sentido:

Aloísio (72 anos, morador do Itararé, bairro praiano de São Vicente): Eu não sei bem o que é terceira idade. É mole? Por exemplo, eu não tenho paciência com esse pessoal da terceira idade que fica jogando dominó, 
baralho, eu não tenho paciência para isso! Eu fui ficar sem trabalhar agora, em fevereiro, e não consegui ficar sem fazer nada. Trabalho desde os dez anos! Sempre! Adoro!

A terceira idade como concepção de um envelhecimento saudável, autônomo, de período privilegiado para realizações pessoais, surge como um discurso das políticas públicas e do mercado para classificar uma crescente faixa da população francesa de classe média que começava a se aposentar, já a partir dos 45 anos de idade. Com a criação dos fundos de pensão, o mercado começou a dar maior atenção para esses jovens aposentados e foi preciso outra denominação para designar essas pessoas que já estavam no fim da fase marcada pelo período de trabalhar, mas com plena autonomia financeira e física; diferente dos primeiros aposentados que paravam de trabalhar já no limite de suas forças. A expressão terceira idade vem para separá-los "dos pobres velhinhos", dos velhos senis, ranzinzas, de maneira a redefinir uma nova maneira de encarar o envelhecimento, como explica Peixoto (2000), que aponta as palavras-chave desse novo envelhecimento:

"Sinônimo de envelhecimento ativo e independente, a terceira idade convertese em uma nova etapa da vida (...) a velhice muda de natureza: 'integração’ e 'autogestão' constituem as palavras-chave desta nova definição. A criação de uma gama de equipamentos e de serviços declara a sociabilidade como o objetivo principal de representação social da velhice de hoje" (Peixoto, 2000, p.57).

Para essa terceira idade é que surge um mercado de produtos e serviços especializados, e outros mercados já existentes se direcionam para esses consumidores em potencial, como fazem as agências de turismo, academias, bingos, etc.

A autora ressalta ainda que na França, onde essa expressão surgiu, a terceira idade é a nomenclatura presente nas políticas públicas de promoção do bem estar da população idosa, numa nova tentativa de classificar os indivíduos e de redefinir a velhice como uma "arte de bem envelhecer" que cada indivíduo deve buscar, "transformando a velhice bem vivida ou decadente num empreendimento privado" (Gullemard, 1976, p.104 apud Peixoto, 2000 p.56). No Brasil, essa idéia chega para promover o mesmo tipo de concepção individualista e otimista de envelhecimento: 
"A rubrica da terceira idade é fundamentalmente empregada nas proposições relativas à criação de atividades sociais e esportivas: idoso simboliza sobretudo, as pessoas mais velhas, "os velhos respeitados", enquanto terceira idade designa, principalmente os 'jovens velhos', os aposentados dinâmicos, como a representação francesa" (Peixoto, 2000: 81).

Em Santos também observamos que a terceira idade é a expressão utilizada nos programas e ações sociais de promoção de atividades lúdicas, de convivência, mas não de assistência. Para essas últimas é reservada ainda a palavra "idosos", como são os "Centros Comunitários da Terceira idade" e as "Repúblicas de Idosos",72.

Por outro prisma, Myriam Barros (2004) salienta que a terceira idade é o desenvolvimento da idéia de velhice na modernidade. Partindo do pressuposto de que "a noção de indivíduo é chave para compreender a sociedade moderna, ou seja, como essa sociedade classifica seus membros", a autora vê na idéia terceira idade o resultado do desenvolvimento da idéia do indivíduo como primado nas interações sociais. Assim a terceira idade é uma imagem de velhice que visa positivar o indivíduo idoso, tão estigmatizado que foi pela sociedade industrial. Nas palavras da autora, essa seria uma nomenclatura para designar

"uma forma de experiência de envelhecer elaborada na sociedade moderna quando a aposentadoria se faz presente como direito social nas nações modernas, quando aumenta a expectativa de vida e quando a ideologia individualista está implicada em todos os níveis da vida. [Vem também de] uma imagem positiva no discurso de especialistas em envelhecimento na área médica” (Barros, 2004:49).

Além disso, a terceira idade é resultado de uma transformação mais abrangente operada pela sociedade de consumo, qual seja a da ampliação da juventude para um estilo de

\footnotetext{
${ }^{72}$ CECOM: definição dada pela prefeitura: "São espaços idealizados para prevenir o isolamento social da Terceira idade [sic], com atividades culturais que estimulam e preservam seu bem estar físico e emocional, valorizando a convivência e as relações familiares e comunitárias". Republica de Idosos: "Proposta alternativa a institucionalização do idoso de baixa renda e a falta de moradias populares, que preserva sua independência, autonomia e convivência comunitária. Eles vivem em Repúblicas com liberdade e conforto, pagando aluguel simbólico, onde os próprios moradores gerenciam as atividades do dia a dia e dividem as despesas da casa". Extraído de http://www.santos.sp.gov.br em 27/10/2006. As Repúblicas e os Centros Comunitários são projetos pioneiros no Brasil da Prefeitura Municipal de Santos, dos quais falaremos adiante.
} 
vida que permeia todas as fases da vida não mais conectada somente a um determinado período do ciclo biológico. Junto com a melhora dos indicadores sociais da população idosa, aumenta a busca de uma aparência e de um estilo de vida jovem, como o mercado sugere, negando tudo o que lembre velhice.

Laslett (1987 apud Debert 1999, p. 162), por sua vez, ressalta que a invenção da terceira idade "requer, a existência de uma comunidade de aposentados, com peso suficiente na sociedade, demonstrando dispor de saúde, independência financeira e outros meios apropriados para tornarem reais as expectativas de que essa etapa da vida seja própria à realização e satisfação pessoal". Esses ingredientes estão todos presentes em Santos, embora junto com outra parcela da população idosa que é menor, mas que existe e está praticamente escondida nos cortiços do centro da cidade. Em meio a tantas transformações, novamente Debert (1999) lembra que é preciso ter sempre em vista que "há uma dissolução dos problemas nas representações gratificantes da Terceira idade (...) na medida em que a visibilidade conquistada pelas experiências inovadoras e bem sucedidas fecha o espaço para as situações de abandono e dependência”. Como ressaltou Peixoto (2000), o uso da expressão terceira idade, assinala uma transformação na imagem do velho, mas não concretamente nas políticas sociais, que quase não se alteraram com relação à população idosa de idade mais avançada e com doenças crônicas manifestas ${ }^{73}$.

No material recolhido na pesquisa de campo, vimos que terceira idade já é uma expressão pejorativa, e agora se usa outras denominações, como "melhor idade", "idade da experiência", "idade da maturidade" e outras, sempre fugindo de qualquer lembrança de velhice. Quando perguntados o que achavam da terceira idade ou do termo terceira idade, entrevistados com mais de 60 anos de todas as partes da cidade e de todas as classes de renda o relacionaram com "estar velho". Alguns logo diziam: "Não me sinto da terceira idade, pois ainda faço tudo, saio, curto a vida...” e outros: “sim, estou né? Fazer o quê? A gente fica velho mesmo”, ou ainda “a velhice é um estado de espírito”, mesmo que a pergunta tenha sido sobre a expressão terceira idade. E as outras denominações que vieram

\footnotetext{
${ }^{73}$ Essa lacuna já começa a ser reconhecida com a oficialização recente da internação domiciliar pelo Sistema Único de Saúde (SUS) para pessoas com mais de 60 anos que necessitem de cuidados especiais, conforme a notícia veiculada no portal do Ministério da Saúde em http://portal.saude.gov.br/portal/aplicacoes/noticias/noticias_detalhe.cfm?co_seq_noticia=28208, acessado em 20/11/2006. Mas essa não é a tônica das políticas públicas que se dirigem à terceira idade.
} 
com o desgaste da expressão também não são suficientes para que se esqueça da velhice, como um grupo de senhores me ensinou de maneira bem humorada:

Gilberto (76 anos, morador do Gonzaga): Você sabe qual a diferença entre o velho e o ancião?

Juliana: Não.

Gilberto: Você deve saber, você é socióloga deve saber.

Juliana: Então me ensina aí.

Gilberto: Velho é aquele que já está esperando a morte, praticamente já está para lá... já não liga mais para nada... está negativo... O ancião é aquele que apesar da idade ele ainda quer fazer alguma coisa de útil...

Juliana: E terceira idade é o quê?

Gilberto: Já vivi na terceira idade, tenho $76 .$.

Tadeu (61 anos): Terceira idade é meia três 63...

Gilberto: Para começo de conversa, você como socióloga deveria saber que não existe mais terceira idade, é "boa idade".

Juliana: E o senhor está na boa idade?

Gilberto: Acho que eu estou, já fiz 60 anos.

Juliana: O senhor está na terceira idade ou na boa idade?

Tadeu: Quando a gente vai no baile do CECOM eles falam “boa idade”...

Juliana: Vocês vão ao baile do CECOM?

Gilberto: Eu vou, eu gosto de me divertir de vez em quando...

A velhice continua sendo algo a se evitar, relacionada com senilidade, com perda das capacidades mentais e físicas, e com o espírito oposto ao da juventude: o de parar no tempo, ou melhor: o de parar. E principalmente: o velho, ou terceira idade é sempre o outro, como já ressaltou Debert (1999). Em todos os blocos (separados por local da entrevista) os entrevistados, embora aceitassem o termo como uma maneira politicamente correta de se referir às pessoas maiores de 60 anos, negavam estar na terceira idade, citando o comportamento de outros para ressaltar o próprio. 
Cláudio (65 anos, vendedor ambulante): Terceira idade acho que é bom. Eu tenho terceira idade, já tenho 65 anos, sou de 1940.

Juliana: E o que é terceira idade para o senhor?

C: Velho, né! O termo certo é velho, mas não me sinto velho. Eu todo mês de maio vou para o nordeste, vou para a Bahia, Sergipe, Recife, Fortaleza, vou para aquelas festas louca lá, as noitadas, chego e não me sinto cansado. Acho que terceira idade é quando os caras ficam jogando dominó, ou você fica dentro da casa ou no apartamento sentado no sofá vendo televisão, se entrega.

Juliana: Então o senhor nunca faria parte da terceira idade.

$C: N \tilde{a} o$.

J: E nem viria aí para a praia para jogar dominó...?

C: Não! Eu? Deus me livre!

Apesar da não identificação com a terceira idade a maior parte dos entrevistados ressaltavam que viviam ativa e saudavelmente, como se estivessem cumprindo seu dever do bem envelhecer, de fazer a sua parte por si mesmo.

Mas enquanto esses festejavam esse período da vida, outros se queixavam das dificuldades trazidas pela velhice. A expressão terceira idade é compreendida da mesma forma, com um mesmo significado, mas a aceitação dessa condição é variada de acordo com as condições de saúde e, principalmente, com a classe sócio-econômica. Os idosos que estavam na praia e no SESC foram os que mais ressaltaram os aspectos positivos da fase da vida em que estão, mas os idosos dos bairros centrais, na mesma faixa de idade dos primeiros, ressaltaram as dores físicas, a falta de dinheiro, a diminuição progressiva no tempo do valor da remuneração da aposentadoria e alguns nem tinham ouvido falar em terceira idade.

As diferenças de classes sociais que se fazem ainda mais marcantes na velhice não se perdem nessa maior visibilidade dos idosos. A imagem da velhice daquele que fica "dentro de casa", que é combatida e rejeitada pela maioria dos idosos entrevistados e de um nascente senso comum, é - quando não se trata de uma escolha pessoal - a velhice daqueles que não puderam conservar boa saúde durante a vida, que muitas vezes tiveram trabalhos pesados, 
insalubres, penosos; que precisam trabalhar na informalidade, sem aposentadoria, portanto; que não têm plano de saúde ou que não têm a tão importante companhia da família, que é ainda a instância cuidadora principal do idoso. Nesse sentido, a "reinvenção da velhice" tem características bem marcadas de classe e gênero que também estão evidenciadas nas localizações freqüentadas por ambos os grupos de idosos em Santos, e principalmente nas áreas residenciais desses dois grupos, como vimos na análise dos dados sócio-demográficos e veremos na pesquisa de campo na seção a seguir, que trata de demonstrar algumas das localizações urbanas de idosos de Santos.

\subsection{Localizações Urbanas de Idosos de Santos}

Chamo de "localizações urbanas de idosos" os lugares da cidade que são centrais para os idosos, bastante freqüentados por eles, sendo reconhecidos pela população em geral como lugares onde se poderão encontrar idosos. Através da pesquisa de campo tentaremos demonstrar algumas dessas localizações e assinalar as principais formas de sociabilidade relacionando-as com o perfil dos grupos de idosos que freqüentam essas localizações.

\subsubsection{Procedimentos da pesquisa de campo:}

A pesquisa de campo que empreendemos foi realizada em quatro etapas. A primeira etapa foi exploratória, com algumas entrevistas nos locais conhecidos pelos santistas por terem muitos idosos: a praia e o SESC. Entrevistei doze pessoas entre homens e mulheres procurando saber aonde mais encontrar idosos, quais as atividades cotidianas predominantes e examinar algumas hipóteses iniciais, como a entrada de migrantes idosos e a concentração residencial nos bairros de alta renda. Essa etapa serviu para delimitar os temas que mereciam ser mais explorados nas entrevistas seguintes. Além disso, conversei mais longamente com senhores e senhoras conhecidos de meus pais, que residem em Santos há mais de trinta $\operatorname{anos}^{74}$. Essas conversas também serviram para mapear inicialmente as atividades que

\footnotetext{
${ }^{74} \mathrm{O}$ fato de ser santista, de ter vivido na cidade por muitos anos e ainda de ter nela uma rede familiar facilitou a pesquisa de campo nas duas últimas etapas. Mostrando ao entrevistado que tínhamos algo em comum, contando meu endereço, por exemplo, a conversa fluía com menos reservas tanto do entrevistado quanto minhas, que podia entender muitas colocações "locais" sem pedir maiores explicações a todo momento.
} 
congregavam os idosos de classe média, como coral, aulas de dança de salão, voluntariado, etc.

A segunda etapa foi a de observar em toda a cidade a interação de idosos com o espaço público e procurar propriamente os espaços que poderiam ser caracterizados como localizações urbanas de idosos. Percorri a pé e de carro as ruas de Santos entrevistando pessoas com 60 anos ou mais no local em que foram encontradas. Durante o percurso, observei e registrei como se caracterizava o espaço intra-urbano de cada bairro, prestando atenção em como era o uso do solo (se era comercial, residencial, ou industrial), os tipos de habitação (se havia mais casas ou prédios, se eram casas pequenas ou grandes, de madeira ou alvenaria), como acontecia a movimentação de pessoas (se andavam de carro ou a pé; se eram muitas ou poucas); se havia espaços públicos para convivência de pessoas, como praças ou áreas verdes, etc. Com isso, busquei relacionar o relato do entrevistado com o local onde estava sendo encontrado. Nessa etapa as entrevistas ("semi-estruturadas") foram gravadas digitalmente e feitas de maneira breve, uma vez que procurei acumular o maior número possível de relatos. Foram entrevistadas 45 pessoas com 60 anos ou mais. Elaborei um roteiro de perguntas, mas não o segui rigidamente como a um questionário, pois variei a ordem das perguntas conforme a disposição da pessoa de respondê-las, às vezes eliminando umas e acrescentando outras, sempre de acordo com o meu objetivo de identificar pontos na cidade freqüentados por idosos, estabelecer as suas trajetórias residenciais (saber onde foram as residências anteriores à atual), e de investigar a percepção que eles têm do seu envelhecimento.

A terceira etapa foi ouvir a história da vida de cinco pessoas: duas mulheres, um senhor e um casal. Essas entrevistas foram agendadas e aconteceram na casa deles. Não houve uma preocupação metodológica em investigar com detalhes a vida do entrevistado, e não seguimos um roteiro específico. Entretanto, eu pedia para que falassem mais sobre alguns temas que interessavam à pesquisa quando não apareciam, como a chegada a Santos (no caso dos não nascidos em Santos), a trajetória profissional e a trajetória residencial. Para essa etapa procurei entrevistar idosos de diferentes classes sociais e diferentes áreas residenciais da cidade. Também tentei entrevistar igual número de mulheres e homens, mas as mulheres foram mais acessíveis para esse tipo de entrevista. Esses depoimentos foram 
utilizados por todo o trabalho, sobretudo no terceiro capítulo, já que ao contar a história de suas vidas, contavam a história da própria cidade. Abriu pistas para aprofundar os temas mais importantes da vida de idosos e, principalmente, nos aproximou do sentimento de envelhecer.

Além dessas três etapas, visitei bailes públicos de dança de salão e ensaios de coral. Ajudaram também, de certa forma, as viagens de ônibus de São Paulo a Santos ${ }^{75}$ (e vice versa) nas quais pude conversar com senhoras e senhores que possuíam residência na Baixada Santista e em São Paulo e ensaiavam morar em Santos ou no Guarujá.

\subsubsection{No espaço público intra-urbano: praças, jardins e a rua.}

Na caminhada pela cidade, observei que em certos bairros os idosos são mais visíveis no espaço intra-urbano público do que em outros. De fato, os bairros que têm menos pessoas acima de 60 anos de acordo com as tabelas apresentadas no capítulo anterior foram os que menos mostraram idosos caminhando nas ruas, em praças, ou simplesmente sentados em frente à porta de casa, como vimos em bairros mais "populosos de idosos".

Podemos agrupar o total de idosos entrevistados em quatro grandes blocos:

a) Bloco Praia: aqueles que foram entrevistados na orla praia. Neste bloco estão incluídos os residentes no Gonzaga, Boqueirão, Embaré, Aparecida e Ponta da Praia;

b) Bloco SESC: entrevistados no SESC (também com residentes dos bairros do Bloco Praia e Bloco Zona Leste);

c) Bloco Zona Leste: entrevistados dos bairros Marapé, Campo Grande, Vila Belmiro, Vila Mathias, Encruzilhada, Pompéia, José Menino e no Morro Nova Cintra;

\footnotetext{
${ }^{75}$ Por trabalhar e estudar em São Paulo e ter família morando em Santos, quinzenalmente pelo menos eu fazia essa viagem. Muitas vezes viajei ao lado de idosos que moravam em Santos ou em São Paulo. Para citar dois exemplos, uma senhora aposentada em São Paulo me contou que estava morando no Guarujá há um ano na antiga "casa de praia", mas que planejava se mudar pra Santos por causa dos serviços e do comércio que são melhores, e outro senhor paulistano contou-me que tinha muitas recordações de adolescência nas praias de Santos e que por ter filhos já morando em Santos pensava em mudar-se para a cidade também.
} 
d)

$$
\begin{aligned}
& \text { Bloco Centro e Zona Noroeste: por serem poucos e com características } \\
& \text { parecidas, colocamos num mesmo bloco (entrevistados da Caneleira, } \\
& \text { Jabaquara, Bom Retiro, Valongo e Vila Nova) }{ }^{76} \text {. }
\end{aligned}
$$

Na fase de entrevistá-los na rua, a caminhada começou pela orla da praia de oeste para leste, a partir da área do emissário submarino, antes do Canal Um, seguindo em direção à Ponta da Praia. Fiz esse percurso em mais de um dia, e no meio da semana para saber se havia variação no uso da orla da praia durante as horas do dia. Também por esse motivo decidi realizar as entrevistas entre segundas e sextas-feiras, ou seja, nos dias em que a praia é menos freqüentada pela população em geral. Nos fins de semana a praia tem muitos veranistas (turistas de segunda residência) e mais santistas de todas as idades e áreas da cidade. Já entre segunda e sextas-feiras (os chamados "dias úteis") predominam os idosos, que preferem esses dias, pois os fins de semana são reservados para a companhia disponível só nesses dias - dos filhos e netos. Assim, nas observações a seguir não estão incluídos os fins de semana, com exceção dos bailes de dança de salão.

Encontrei mais idosos durante a manhã do que à tarde e um número ainda menor à noite, embora os tenha encontrado. Muitos disseram que realmente são esses os períodos em que mais gostam de freqüentar a orla da praia: preferencialmente de manhã, um pouco a tarde e menos ainda à noite.

Um dos primeiros pontos que se destacou na orla pela presença de idosos foi a plataforma do Emissário Submarino de manhã e no começo da tarde em dias ensolarados (nos dias chuvosos eles não vão à praia, predominando os surfistas). À medida que anoitecia apareciam grupos de jovens, com o som do carro ligado, alguns fumando maconha, e em pouco tempo os idosos deixavam o local. Junto com eles, iam embora também alguns poucos vendedores ambulantes. Assim, “o Emissário” é visto como um lugar "legal e

\footnotetext{
${ }^{76}$ Não foi possível entrevistar idosos em todos os bairros da cidade porque muitos não aceitaram conceder a entrevista (principalmente nos shoppings), e em outros eles não estavam parados (Morros, Boqueirão, Embaré), sendo impossível a abordagem, além daqueles bairros em que não os encontrei na rua (Santa Maria, Macuco, Estuário, Areia Branca, Vila São Jorge, Jardim Rádio Clube, Jardim Piratininga, Morros, com exceção do morro da Nova Cintra). A divisão dos blocos é pelo local onde foi realizada a entrevista, e não pelo bairro da residência do entrevistado, de forma que encontramos pessoas do Jardim Rádio Clube na praia, do Saboó na pracinha da Carvalho de Mendonça, etc.
} 
gostoso de ficar, mas só até o fim da tarde”. Temos aqui um exemplo de como uma mesma localização adquire sentidos diferentes de acordo com a hora do dia.

Como nosso objetivo foi observar quem eram as pessoas idosas que circulavam na cidade, não procuramos entrevistar número igual de mulheres e homens, forçando uma amostra igual entre os sexos. A proporção entre os sexos na nossa amostra foi a que encontramos disponível no espaço intra-urbano, e o resultado foi uma grande maioria masculina, o que não ocorreu, no entanto, nas entrevistas que foram agendadas e nem naquelas realizadas nos estabelecimentos com atividades direcionadas ao público maior de 60 anos. Nesses locais seria quase mais adequado dizer "público de idosas", tamanha a proporção maior de senhoras, viúvas em sua maior parte.

No espaço da praia ${ }^{77}$ há idosos realizando atividades diversas:

a) Há aqueles que preferem ficar sentados nos bancos do extenso jardim que permeia toda a orla lendo jornal, observando a paisagem e o movimento de pessoas.

b) Há os que fazem caminhadas na areia e no calçadão atrás do jardim, e os que realizam alguma atividade física organizada pela prefeitura, como o pessoal que joga tamboréu toda terça e quinta às oito horas da manhã.

c) Há os que tomam banho de sol na areia da praia. Entre esses há os que estão passando temporada na cidade, como o casal de mineiros de Varginha que pensa em se mudar definitivamente para a cidade, assim como a mãe de 80 anos e a filha de 53 anos, paulistanas, que tinham apartamento há 30 anos em Santos, e esperavam a aposentadoria da última para se mudar de vez.

d) E o pessoal que fica jogando damas, dominó e carteado nas mesinhas de cimento em frente aos quiosques próximos próximo ao término de cada canal na praia.

\footnotetext{
${ }^{77}$ Consideramos a praia de Santos como um conjunto de espaços, cada um, com um tipo de uso predominante. De fora para dentro temos, conforme mostra a figura 13 na página seguinte: a avenida da praia (calçada e vias de circulação de veículos), o jardim, a calçada que fica entre o jardim e a areia, o banco de areia e o mar. Na ponta oeste temos o Emissário Submarino, quase se limitando com São Vicente, e na ponta leste há o "Ferry Boat" (balsas e barcas).
} 
Nos bancos do jardim a maior parte dos entrevistados foi de residentes, e desses, alguns há menos de dez anos. Do total de 45 pessoas que aceitaram me conceder entrevistas nessa etapa da pesquisa, cinco foram turistas veranistas que compraram apartamentos nos prédios da orla há muito tempo e agora usam a antiga segunda-residência para passar parte da semana na cidade, e outros sete haviam acabado de fixar residência em imóveis adquiridos recentemente (menos de cinco anos).

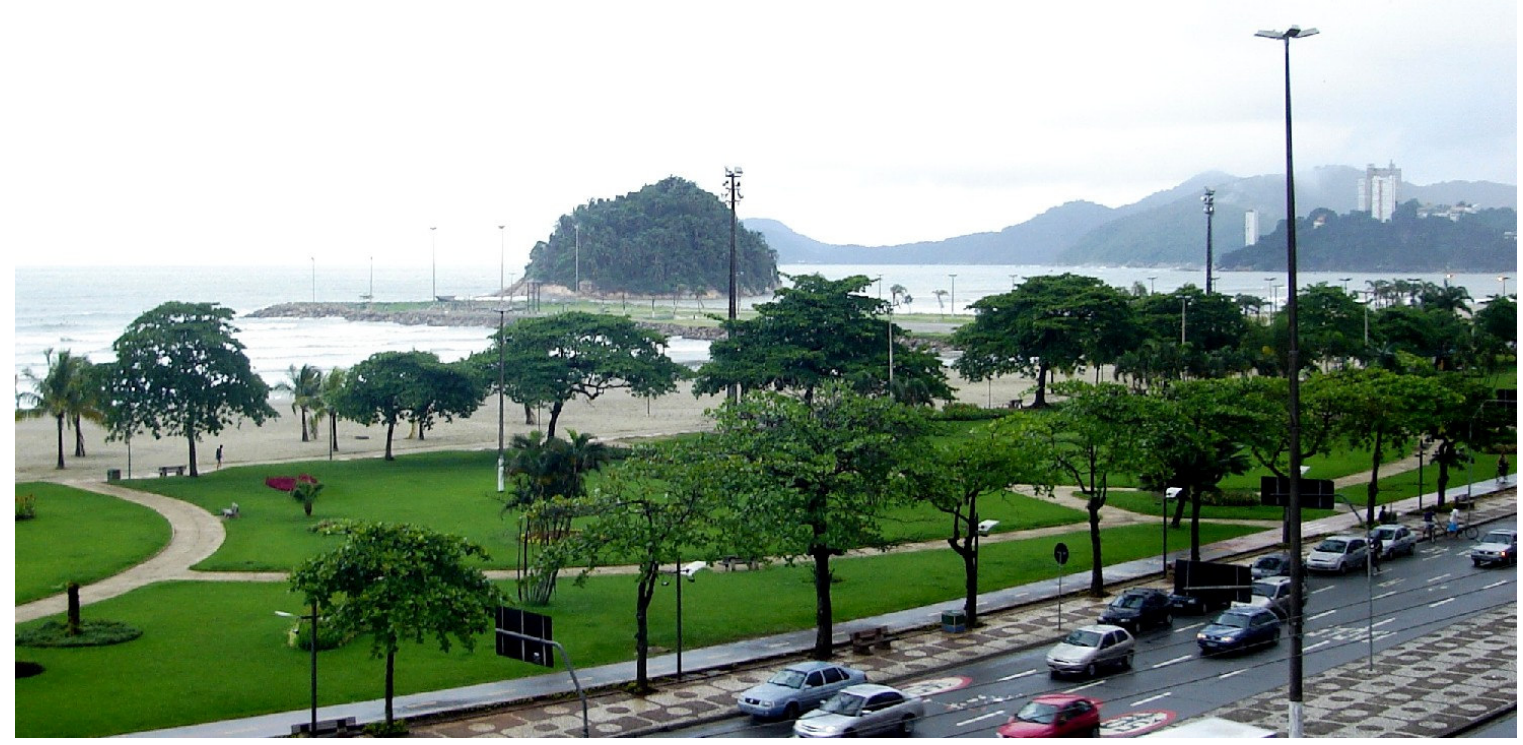

Figura 13: Avenida Presidente Wilson, praia do José Menino, e o jardim que continua até o canal 6, conforme a nota 79. Ao fundo em segundo plano há o Emissário Submarino e a Ilha de Urubuqueçaba logo atrás. Mais ao fundo e à direita, a Ilha Porchat. Foto da autora, outubro de 2006.

No jardim, pela manhã, encontrei também santistas que moraram em outras regiões da cidade, ou em outra cidade da região metropolitana e ainda trabalhavam; todos estes homens que costumavam ${ }^{78}$ ir à praia de manhã e trabalhar a tarde. Muitos destes trabalhadores já haviam se aposentado, mas precisavam complementar a renda. Entre eles havia zeladores, vendedores ambulantes e catadores de latinha.

O maior uso da praia de Santos é sem dúvida, o da caminhada, e a maioria dos que caminham entre homens e mulheres (pelo menos à vista) são as idosas de aparentemente

\footnotetext{
${ }^{78}$ As informações a seguir são as dos senhores e senhoras que estavam dispostos a conversar, e não podem ser encaradas como um retrato do perfil dos freqüentadores idosos da praia.
} 
entre 60 e 80 anos, geralmente acompanhadas de seus maridos ou com amigas, no começo da manhã ou no fim da tarde.

De maneira geral, os jardins da orla da praia são mais freqüentados por homens sozinhos que apenas contemplam a paisagem natural e urbana. Pela noite, os bancos do jardim que são voltados para o mar, fora da vista da avenida, são ocupados por casais de namorados jovens, mas na parte voltada para a avenida é possível ver idosos sozinhos, geralmente homens, até às 22 horas.

Entre as atividades cotidianas relatadas pela maioria dos entrevistados nessa etapa, a sociabilidade apareceu bastante diferenciada entre os sexos. Usar o espaço da rua, da praça mais propriamente, como local de permanência é uma prática quase totalmente masculina. Até mesmo passear pelo bairro também se usa mais entre os homens do que entre as mulheres, que preferem as áreas comerciais de luxo, como o Gonzaga, o Boqueirão e os shoppings. As mulheres quando saem de casa têm um destino definido, já os homens gostam mais de sair somente para caminhar pelas ruas - o que é diferente da caminhada como atividade física, praticada na praia por ambos os sexos. As poucas entrevistas com mulheres no espaço da rua foram somente de manhã, e com viúvas de mais de 70 anos. Sozinhas, elas tomavam sol nos bancos da calçada voltados para a avenida, pois gostavam de observar o movimento das pessoas indo trabalhar e de casais que passeavam de mãos dadas. Era a cena urbana que as atraía, e não somente a paisagem do jardim ou da praia. Mas a rua como local de permanência é domínio masculino; tanto que as únicas senhoras mais jovens que encontramos sentadas nos bancos - e não fazendo caminhada - estavam em grupo.

Essa diferença de atitudes com relação à rua já se coloca na divisão cotidiana das tarefas do lar. Na vida doméstica, enquanto as mulheres ficam com a arrumação da casa e o fogão, onde podem exercer sua sedução culinária, os homens ficam com as tarefas de "fora de casa”, como ir à padaria, pagar contas, ir ao supermercado, buscar os netos na escola, etc; às vezes tomando essas tarefas para si, como demonstra o diálogo tão freqüente e cotidiano entre o casal de entrevistados que me contavam o que faziam durante o dia:

Aurélio: Se tiver algum biscatezinho para fazer dentro de casa eu faço... 
Laurinda: [Ele] Vê jornal, vê tv, vai comprar alguma coisa... Ele vai para as compras, vai no supermercado... Eu sou uma dona de casa que não sabe quanto custa um pão. Não sei quanto custa um quilo de tomate...

Aurélio: Aqui já me trocaram de nome!

Juliana: Ah é?

Aurélio: É, é “Jáque”.

Juliana: Por que "Jáque”?

Aurélio: "Já que tu num ta fazendo nada vai me comprar isso daqui!" [risos].

A esposa interrompe:

Laurinda: Mas é mesmo! Aí ele fala: “Não quer nada?” Aí eu falo: "quero não”. Ele fala: “Não quer que vá na feira?” Não, já tem tudo aí.

Aurélio: Aí ela vai e fala "traz só pepino e maçã".

Laurinda: Aí ele traz pepino, traz maçã, traz um monte de coisa ...

É muito comum eles esticarem esse caminho e vivenciarem um pouco a experiência do flaneur evocada por Walter Benjamim - o solitário indivíduo moderno que "flana" sem rumo certo na cidade. Como contou o Sr. Rogério, que tinha uma conta a pagar no centro da cidade e resolveu ir a pé (saindo do Marapé), ao invés de pegar o ônibus (que para ele que tem mais de 65 anos é de graça). Ter "um compromisso" é ter a oportunidade de sair do marasmo "de dentro de casa", do mundo doméstico, domínio feminino entre os idosos. Laurinda pede para que ele vá comprar frutas e legumes, mas ele também se oferece para ir. Talvez por isso em todos os bairros os homens foram maioria nas ruas e praças. Nesse sentido, vale a pena alongar essa pausa na descrição do uso da praia para nos voltarmos ao cotidiano dos idosos, pois essa diferença de atitudes femininas e masculinas em relação à casa também está presente na escolha das atividades cotidianas.

Entre os homens as atividades de programas da terceira idade quase não exercem apelo. Daqueles senhores que passeavam na praia, na rua ou que estavam nas praças somente dois (entre os 45 entrevistados nessa etapa) afirmaram freqüentar o SESC, o 
CECOM e os bailes de dança de salão ${ }^{79}$. Mas todos disseram que gostam de passear e fazer compras na cidade.

Aqueles que ainda trabalhavam, os que se aposentaram recentemente, ou os que não freqüentavam assiduamente nenhuma pracinha, preferiam preencher o dia com atividades "úteis". Uma delas é ajudar os filhos; outra, muito importante, é realizar cuidadosamente compromissos pessoais. Entre eles, os cuidados com a saúde ocupam um lugar importante porque são encarados também como uma função e uma atividade que exige perícia: escolher bons médicos, alimentar-se da maneira mais adequada, fazer exercícios físicos; o bem viver é uma arte, um ofício no qual o idoso tem que se aprimorar. Essa idéia, iniciada pelo discurso médico, como mostrou Debert (1999), Barros, (2004), e outros, já está incorporada no discurso tanto dos homens como das mulheres. Assim, preenchem o dia de maneira "útil":

Otávio (74 anos, morador da Vila Belmiro): É aquela rotina, divido o tempo. Minha filha trabalha também, passa o dia todo fora... Às vezes fico em casa com minha mulher e minha filha... Também tenho problema de saúde. De vez em quando vou ao médico marcar exame: uma vez é no dentista, outra é em clínica, às vezes é no de próstata; não tenho próstata, mas precisa fazer o exame... É aquilo que lhe falei: divido o tempo...

Outras atividades cotidianas desempenhadas rapidamente sem muita atenção por pessoas que ainda estão trabalhando ou donas de casa muito ocupadas, como, por exemplo, as compras semanais do supermercado, são feitas com muito mais atenção pelos idosos. Eles pesquisam mais os preços e não se preocupam com o tempo que isso pode tomar. Assim como os homens gostam de ler o jornal inteiro (e não só a parte que mais interessa), e assistem regularmente os jornais televisivos. A vida pessoal cotidiana é um mundo que exige atenção, e se os seus filhos, sobrinhos e netos não tem tempo suficiente para cuidar dela, eles sempre têm dicas para ajudar, quando não tomam as tarefas para si. As mulheres, mais

\footnotetext{
${ }^{79}$ Em compensação, muitos dos idosos encontrados nesses eventos lúdicos afirmaram ir à praia, geralmente pela manhã. Mas a para esse grupo, a praia é mais um local de atividades físicas, da tradicional caminhada, do que um local de sociabilidade.
} 
sobre as atividades de dentro de casa (dicas de culinária, de limpeza, de decoração da casa ${ }^{80}$ ), e os homens atentos ao mundo lá fora: a política, a novela, e a outros assuntos "técnicos" do cotidiano, como a mecânica do carro, as contas, enfim, às tarefas fora do espaço da casa.

Nas rodas de conversa, principal maneira de permanecer no espaço público da rua, entre os homens, o papo se mantinha nos assuntos do mundo público: a economia, o governo, a política local, as últimas notícias do jornal local... E entre as mulheres, os assuntos do mundo privado: culinária, doenças, a escola dos netos, a família dos filhos; uma exceção talvez sejam os programas de televisão, também muito discutidos, sobretudo as novelas, que novamente, tratam dos assuntos do mundo privado.

Contudo, essa divisão público/privado, masculino/feminino está cada vez mais sendo dissolvida, sendo que ela é mais freqüente entre os idosos mais velhos (já de 75 em diante). A nova geração dos sessenta anos, mais entre aqueles de classe média ou média alta, está cada vez menos entrando no mundo à parte da terceira idade, pois não raro continuam trabalhando, ou têm um projeto definido de vida: dedicar-se a algum hobbie, desenvolver trabalhos voluntários, enfim, realizar algum projeto, com metas e produtos ${ }^{81}$. Novamente, a noção de "utilidade" presente - dessa vez, ligada à de realização pessoal. No entanto, ter um projeto de vida alternativo e maduro não é algo imediato logo após a aposentadoria. Muitos só pensam sobre a vida "pós-trabalho" depois que param de trabalhar. À medida que pensam, não param; o segredo é não parar, enquanto o cotidiano, os eternos afazeres do lar, vão preenchendo o dia:

Rui (68 anos, morador do Gonzaga): Ando com ela [a esposa], fico com ela para lá pra cá, no fim do mês quando a gente recebe vou pagar as contas, comprar o que falta em casa, dar uma volta com meu filho, dar uma volta com meu cachorrinho...

\footnotetext{
${ }^{80}$ Embora cada dias mais elas estejam saindo de casa e dominando todas as atividades cotidianas. Essas dicas sobre facilidades domésticas são cada vez mais das senhoras mais velhas (de mais de 70 anos).

${ }^{81}$ Esse pode ser mais um exemplo da colonização do tempo livre pelo sistema capitalista, como apontaram estudos clássicos das ciências sociais, notadamente Adorno e Horkheimer em $A$ indústria cultural e $A$ Dialética do Esclarecimento e Habermas em Técnica e Ciência como "Ideologia". Acreditamos que na aposentadoria $o$ trabalho continua presente por meio da sua racionalização e da transformação das ações do tempo livre em atividades, em ações racionais com respeito a fins. Mas longe de nós desenvolver esse tema aqui, que merece reflexão futura.
} 
Murilo (65 anos, morador do Campo Grande): Fico um pouco na praia, fico com minha esposa, às vezes vejo alguma coisa do meu automóvel, vejo alguma que precisa para casa, pra minha filha, para minha irmã, aquele convívio, mas, nada que me prenda àquela rotina de casa, não tenho nenhum problema de fazer aquela rotina diária, não. Sem compromisso.

Carlos (64 anos, morador do bairro do Marapé): Como falei: à tarde faço alguma coisa escrita, porque eu trabalhei em banco antes, vejo o extrato do banco, a noite tomo um banho, faço um lanche, e dou uma caminhada no Gonzaga...

Hugo (74 anos, morador do bairro do Gonzaga): Meu caminho é 5 horas na casa da minha filha, meio dia e meia vou para casa, fico até as 4 horas e venho pra cá [um café dos filhos], fico até às 10 horas [da noite] e depois vou pra casa. (...) Não eu só ajudava, é da firma aqui, eu trabalho porque gosto de trabalhar.

Como residem predominantemente nos bairros com mais comércio e serviços, os idosos não precisam se deslocar para outras regiões da cidade para satisfazer suas demandas mais freqüentes. No caso dos hipermercados, os dois que existem na cidade estão nos bairros do Boqueirão e no limite do bairro do Campo Grande com o bairro do Gonzaga. As consultas médicas, as aulas de ginástica, o ensaio do coral, a missa ou o culto, o SESC, o CECOM, os bailes, tudo está próximo a pé ou de ônibus, que é gratuito aos maiores de 65 anos:

Juliana: O senhor vai de ônibus ou de carro? [ele dizia que gostava de ir ao cinema, à praia...]

Marcelo (75 anos, morador do Boqueirão): De ônibus. Eu não tenho mais carro. Aqui não tenho. Nem uso. Os lugares são pertinhos... Eu não tenho 
mais carro... Aos lugares que ficam mais longe vou de bicicleta, então não preciso de carro. Acabei de compreender que carro me dá mais preocupação do que tranqüilidade.

No deslocamento para esses eventos pouco precisam sair dos bairros praianos, avançando pouco para o interior da Ilha, a não ser diretamente à zona central, onde podem usufruir do comércio (mais amplo e mais barato que no Gonzaga), visitar a pequena área do centro histórico restaurado, onde há o Museu do Café, o Bonde Turístico, ou ${ }^{82}$ quando têm algum compromisso com o aparelho administrativo da cidade, que está concentrado nessa região da cidade. Nesse caminho, raramente param pelos bairros adjacentes ao centro, a zona central expandida onde estão os cortiços atuais (Vila Nova, Parte do Macuco, arredores do Mercado Municipal...).

Assim, excetuando os deslocamentos para o centro da cidade, percebemos que as localizações urbanas de idosos são definidas, em geral, com relação à moradia daquele que se desloca até ela. O local da moradia é sempre o ponto de inicial do deslocamento, principalmente dos deslocamentos que visam o lazer, como é o caso dos aposentados santistas. Por isso, a área residencial deles é importante: são as áreas referenciais que elegerão os espaços acessíveis.

As ruas dos bairros que têm mais idosos, com raras exceções, são amigáveis para passear. São planas, têm calçadas largas, pouco movimento de carros e de ônibus e pouca poluição (com exceção das avenidas dos canais que são artérias de circulação do transporte coletivo, e de algumas ruas do Boqueirão, como a Rua Oswaldo Cruz e a Rua Azevedo Sodré, essa última de comércio de luxo). O espaço intra-urbano de Santos é convidativo, ao contrário de outras cidades de relevo acidentado, calçadas irregulares, mais movimento de carros do que de pedestres, como São Paulo e Campinas. Assim conta o veranista paulistano que morava em Campinas de 83 anos que fumava calmamente encostado na mureta do Shopping Balneário, às vinte e duas horas de uma quinta-feira:

\footnotetext{
${ }^{82} \mathrm{O}$ Teatro Coliseu que fica a poucos quarteirões afastado do centro histórico tornou-se, recentemente, depois da sua restauração, alvo de deslocamentos de idosos, mas somente em dias de espetáculos e normalmente pela noite.
} 
Eugênio: Eu venho sempre aqui. Lá em Campinas a gente não tem condições de ficar até tarde, ali assaltam a gente. Eu mesmo já fui assaltado durante o dia três vezes!

Voltando aos blocos de entrevistados, o bloco praia foi o mais heterogêneo. Foi nesse bloco que encontramos os maiores graus de instrução e também o maior poder aquisitivo. Alguns poucos (apenas três) disseram ser proprietários de estabelecimentos de comércio, fábrica, escritórios, e imóveis. Mas também encontramos aposentados portuários, ensacadores, professores, comerciantes, advogados que de vez em quando ainda exerciam a profissão, etc. A praia pareceu-nos o espaço mais democrático: não há nenhum tipo de delimitação como nos bailes que há o cerco de cadeiras em torno do espaço dos dançarinos, e como em algumas praças reformadas recentemente que foram gradeadas (Praças dos Andradas, em frente à rodoviária). Na praia há apenas a diferenciação entre os espaços, como há em toda praia urbanizada. Os entrevistados eram de locais variados, tanto da Zona Noroeste como da Zona Leste, porém com nenhum entrevistado da Zona Central, o que pode se dever à nossa pequena amostra, embora os poucos entrevistados do Centro afirmassem não ir à praia.

Apesar de não procurarem atividades lúdicas naquele local, os idosos que freqüentam os bancos da praia formam grupos. Eles vão se conhecendo à medida que percebem que têm horários e usos parecidos da praia. Com alguns minutos de conversa já se cria um laço que se retoma em outros dias, e assim, as rodas de conversa vão adquirindo tempo e espaço definidos. Grupos de senhores ou de senhoras começam a se encontrar todos os dias geralmente pela manhã para falar da vida da família, dos filhos, de doenças, da novela, de pessoas famosos, de viagens que fizeram, do governo, do presidente, do prefeito, da aposentadoria... Em toda a cidade os grupos de homens, são mais freqüentes e quase sempre algum tipo de jogo medeia e oferece o pretexto pra reunião (carteado, damas, xadrez...).

As mesinhas de cimento ao lado dos quiosques do final do Canal Três (praia do Gonzaga) se destacam entre todos os outros quiosques e canais pela presença constante de homens idosos jogando damas e carteado. Atualmente tem também campeonatos de xadrez 
nos quais participam jovens (depois das 18 horas geralmente). A qualquer hora do dia é possível encontrar homens mais velhos por lá. A maior parte deles vem das redondezas, mas há uma pequena parcela que não mora por perto e chega a tomar ônibus para ir até lá.

O Sr. Júlio, 67 anos, que mora no Jardim Rádio Clube (Zona Noroeste) é um exemplo. Ele vai lá quase todas as manhãs para encontrar seus amigos e parceiros de jogo. Diferente de outros que freqüentam o mesmo local, o Sr. Júlio trabalhou como ensacador no porto até 1989, quando se aposentou por invalidez, mas ainda trabalha como catador de latinhas de alumínio usadas. Tem três filhos casados e um deles ainda mora com ele, junto com a nora, de forma que ele é o chefe de um domicílio de duas famílias. Pelas manhãs é possível encontrar o Sr. Júlio na praia, naqueles quiosques. Pela tarde ele está trabalhando. Nas mesmas mesinhas de cimento, num fim de tarde, conversei com o Sr. Marcelo, 76 anos, que mora a poucas quadras dali (bairro Boqueirão, Zona Leste). Há quinze anos que ele vem se encontrar com seus companheiros para conversar, jogar e passar o tempo. O cotidiano dele é bem diferente daquele do Sr. Júlio. De manhã suas atividades são as seguintes:

Marcelo: Costumo correr na praia, gosto de correr descalço. Faço 5km, ida e volta. Daí fico por aqui e o tempo passa rapidamente. Também leio o jornal, gosto muito de música clássica, faço pesquisa, leio revistas...

Juliana: Pela tarde também?

Marcelo: À tarde também. Gosto de ler a noite, vou ao cinema... Apesar de ter televisão a cabo, ainda vou ao cinema, gosto de tela grande. Eu já fui assim... um entusiasta, pode se dizer assim, um cinéfilo, sempre me interessei. Não me deixo ficar sem ter o que fazer. Às vezes o tempo passa rápido demais, o tempo fica curto realmente!

Juliana: E aqui o senhor costuma vir bastante?

Marcelo: Venho pra cá... Aliás, eu quem praticamente introduziu a prática diária do xadrez, mas o nível do pessoal está mais alto do que o meu, então eu assisto mais do que jogo. 
Nesse sentido poderíamos confrontar a afirmação de Simmel de que a sociabilidade não deve se dar entre membros de classes sociais muito diferentes. Mas, Simmel também afirma que a sociabilidade proporciona o ambiente de um mundo ideal. "Riqueza, posição social, cultura, fama, méritos e capacidades excepcionais não podem representar qualquer papel na sociabilidade" (Simmel, 1983, p.170), de forma que desigualdades sociais ficam disfarçadas naqueles momentos necessariamente finitos de interação lúdica. As diferenças não são diluídas, mas encobertas, propositadamente esquecidas. É um mundo "composto por indivíduos que não têm nenhum outro desejo além de criar com os outros uma interação completamente pura, que não é desequilibrada pelo realce de nenhuma coisa material", por isso é preciso que as diferenças de classe sejam encobertas.

Como não fizemos uma observação longa, etnográfica, não podemos fazer muitas afirmações a respeito da força dos vínculos afetivos que se formam ali, mas com certeza podemos afirmar que esse local pode ser caracterizado como uma localização urbana de idosos. Entrevistados encontrados em outros locais da cidade lembraram-se dessa pracinha, dizendo que "é lá que ficam aqueles homens que jogam o dia inteiro e não fazem nada" assim disseram alguns outros senhores que se concentravam nas atividades do dia a dia, ou que ainda trabalhavam e algumas mulheres. É uma localização urbana de idosos caracterizada por uma sociabilidade predominantemente masculina. $\mathrm{Na}$ verdade, não encontramos nenhuma mulher nas rodas de carteado e damas que visitamos.

A existência das pracinhas com mesas de cimento é mais comum nos bairros da Zona Leste e nelas foi fácil encontrar homens mais velhos, sozinhos ou com outros, mas nunca com mulheres. Alguns desses lugares se destacam como pontos de maior centralidade, como é o encontro das ruas Carvalho de Mendonça e Rua Guararapes com a Avenida Bernardino de Campos (canal 2). Esta pequenina quadra com mesinhas de cimento é bastante conhecida no bairro e freqüentada há muitos anos (mais de 15 anos com certeza). Seus freqüentadores - homens predominantemente com mais de 50 anos - são assíduos todas as tardes, e alguns ficam durante todo o dia até a noite.

A maioria deles mora por perto ou já morou no bairro do Campo Grande e mudouse. Esses, então, vêm de outros bairros para reencontrar os amigos e parceiros de jogo. Alguns se mudaram para a orla da praia; o bairro mais citado novamente foi o Gonzaga. 
Outros se mudaram para residências maiores em bairros menos caros, como o Saboó, o Areia Branca e o Jardim Rádio Clube. Todos com que conversei eram aposentados; alguns com três anos, outros com 20 anos de aposentadoria. Muitos se conheceram antes de se virem na pracinha, no trabalho portuário, embora haja entre eles comerciantes e trabalhadores das indústrias de Cubatão, como a Petrobrás e a Cosipa, todos das chamadas “camadas médias”, como também constatou Peixoto (2000) para esse tipo de sociabilidade.

Essa praça pode ser tomada como uma localização urbana de idosos. É uma referência para o bairro e para eles, que dividem o dia entre os períodos que estão na praça, e fazendo outra coisa, ou em casa. Ficar na praça, para a maior parte, é uma atividade que preenche dias inteiros. Perguntados se são da terceira idade, a maioria diz que sim, pois "a idade já é avançada, e não há como negar”. Poucos associam a expressão com uma velhice ativa, diferenciada, ou como uma fase da vida anterior à velhice. Não costumam freqüentar as atividades do SESC e dos CECOMs porque não gostam ou porque já estão satisfeitos com o que têm. Como disseram, ficam quase o dia todo jogando, mas de manhã vão à praia, geralmente a pé. Esse grupo prefere ocupar o tempo com o jogo e também com as atividades do dia a dia que ainda sobraram. Na verdade o jogo, muitas vezes, é só o pretexto para sair de casa e conversar:

Juliana: Vocês conversam sobre o quê?

José: Aqui a gente conversa de qualquer jeito... Sobre a situação do país, sobre o presidente da república, sobre mulher... A gente fala mais é do governo, que aposentado nunca está satisfeito, devido às atitudes que o governo toma em relação aos aposentados. Nunca está satisfeito, é sempre pra criticar, dificilmente você vê uma atitude que é para beneficiar, como agora, que o governo deu 14 não sei o quê de aumento para o salário mínimo. Trezentos: 60, pra 240 dá o quê?? Uns 14\%. Para os aposentados é 5! Micharia! Lá, agora, você pega o aumento que dá na água, na luz, mais 40,00 para a empregada e mais o que aumentou de medicamento o que você vai receber já não dá pra cobrir tudo isso. Tá compreendendo? 
Eles estão alerta. Também nessas conversas trocam informações sobre seus direitos e constroem suas opiniões sobre assuntos importantes para eles, como o Estatuto do Idoso, por exemplo:

Tito: É, mas não vejo vantagem nenhuma. Que você veja minha condição, sou aposentado. Não é 60 anos [que se considera idoso]?

Juliana: Pelo Estatuto é.

Tito: Pois é, porque pra andar de ônibus é 65! Alguém está comendo alguma coisa aí, porque é 60! Por que pra prefeitura é 65? Fora os bancos! Os bancos que são do governo são mais safados ainda! Se você vai no banco da Caixa é pior ainda, não tem vantagem nenhuma, é uma pena... que eu sei, mas não vejo vantagem nenhuma.

(...)

Juliana: E as atividades culturais que têm para o pessoal da terceira idade, o senhor já foi em alguma?

Tito: Não digo que não vou, não... Sei que tem um bocado de coisa, baile, mas não vou.

Juliana: Por quê??

Tito: Não vou porque não me interessa.

Do outro lado da rua tem um ponto de táxi de motoristas idosos, com quem também conversei. O ponto é antigo, de forma que eles acompanham há muitos anos o movimento da praça. Pedi para que me indicassem outros locais onde eu poderia conversar com pessoas de 60 anos ou mais, e a primeira referência foi o SESC, depois do hipermercado Extra e outras pracinhas na Vila Belmiro, no próprio Campo Grande e na Aparecida. Seguindo esse caminho, encontrei outras praças com mais idosos homens. O tipo de interação lúdica observada foi a mesma: o pretexto da sociabilidade continuava sendo o jogo de cartas, de damas, às vezes de xadrez. Mas em algumas esquinas, observei que a interação se dava por ela mesma, sem outros motivos ou pretextos. Assim acontece na muretinha do Canal Um (Avenida Pinheiro Machado), na esquina com a mesma Rua Carvalho de Mendonça (limite 
entre o Marapé e o Campo Grande), como conta o Sr. João, que vai lá todos os dias de segunda a sexta:

João: Durante o dia vou ao centro fazer alguns pagamentos depois volto, almoço; depois do almoço faço algumas coisas... As filhas pedem pra fazer alguma coisa, faço, depois venho aqui para o canal bater um papo com o pessoal.

No dia em que os entrevistei eram quatro homens discutindo inflamadamente o pequeno aumento do salário mínimo (na época, de 240 para 300 reais), que não ajudava em quase nada com os gastos deles. Quando expliquei os propósitos da minha pesquisa e perguntei sobre o que gostavam de conversar, logo explicaram que falam muito do governo, e me explicaram como a aposentadoria "tá diminuindo", "o governo comeu tudo". Nesse grupo todos moravam por perto e o encontro era rápido, mas diário, sempre no fim das tardes. Entre cinco e seis da tarde é o horário que eles terminam de realizar os seus compromissos diários cotidianos, e preparam-se para encerrar a "jornada": ir pra casa, tomar banho, lanchar e ver televisão. São companheiros de bairro, de condição de vida e dois deles trabalharam juntos, no Porto. Estão aposentados há muito tempo: há 30 anos o Sr. Manoel, há 27 anos o Sr. Tadeu, e o Sr. Hélio, o mais novo freqüentador, há três anos. Mas começaram a se reunir a pouco mais de cinco anos, pois não pararam de trabalhar depois que se aposentaram. O Sr. Hélio trabalhava nas Docas (CDS) e depois virou pintor de paredes. Agora não pinta mais porque as pessoas "só querem pagar parcelado e assim eu não posso".

Essa esquina já está ficando conhecida no bairro, e pode ser a nosso ver, considerada uma pequena localização urbana de idosos; um ponto acessível para eles, no cruzamento de duas vias de ligação dos bairros residenciais de classe média Marapé e Campo Grande com outros bairros. A muretinha do canal funciona como um banquinho. Antes, no mesmo horário, era só um lugar de passagem dos estudantes do colégio em frente. Agora é um ponto de encontro de aposentados.

Essa localização urbana, assim como as outras pracinhas que visitamos, não tem uma centralidade significativa para toda a cidade. Não se pode compará-la com as mesinhas do canal três, por exemplo, que estão numa das principais avenidas de Santos, e recebe idosos 
de diversos pontos da cidade ou com a movimentada esquina do Canal Dois com a Carvalho de Mendonça. Assim como essa, outras localizações urbanas de idosos que encontramos são mais representativas para seus bairros do que para a cidade, sendo locais onde ainda se pode encontrar o senso de comunidade. Sempre que perguntava aos idosos encontrados nesses lugares sobre o que mais gostavam em Santos, na resposta não vinha só a praia, a grande atração, mas seus amigos, seus companheiros, inclusive entre os mais pobres. O senso de comunidade é muito prezado e buscado pelos idosos de todos os blocos, e nesses locais de encontro, perto de casa, acessíveis a pé, eles revivem um pouco do sentido do bairro, de vizinhança, de quando a cidade era menor (e eles mais jovens). Ao nosso ver a grande contribuição urbana das localizações urbanas de idosos é a da recuperação da sociabilidade entre vizinhos, dos contatos primários em meio à proliferação dos contatos secundários que caracterizam as cidades que crescem e se modernizam, como Santos. È a oportunidade de conversar sobre o mundo e trocar opiniões ou construir opiniões juntos.

Assim pude presenciar na pequena mureta do Shopping Balneário (Avenida Ana Costa, próximo à praia). A mureta ao lado da entrada do shopping é tradicional ponto de encontro entre os jovens, mas na ponta, quase na esquina, um pedacinho do muro fica com um grupo de senhores que se encontra ali todas as noites, por volta das 21:00, no horário da novela das oito (que eles não gostam de assistir). Entre eles, há trabalhadores informais, aposentados, e aposentados que não puderam parar de trabalhar. Mais um exemplo de sociabilidade entre indivíduos de classes sociais diferentes. Mas nesse grupo há um elemento especial: eles se conheceram ainda na juventude, e se reuniam ali por perto, quando nessa quadra da Ana Costa com a Avenida Vicente de Carvalho (avenida da praia) ainda havia cinemas, e o local da atual Lojas Americanas e Mc Donalds abrigava um salão de jogos. Depois de algum tempo, algumas pessoas daquela época se reencontraram e voltaram a se reunir pra conversar, agora nessa esquina, que oferece a paisagem bonita da praia e o movimento de pedestres de todas as idades. Todos os dias tem alguém, mas quando tem jogo de futebol (geralmente os jogos do Campeonato Brasileiro que são televisionados por volta das 21:30h) tem menos senhores. Nem quando chove eles deixam de se reunir, pois entram no shopping e ficam na praça de alimentação, ou em algum banco. Esse encontro é um hábito e faz parte do dia de quem tem cotidianos muito diferentes, como podemos 
observar nos relatos do Sr. Nilson, que precisa trabalhar pra aposentar-se por tempo de idade, e do Sr. Geraldo. O Sr. Nilson, que trabalha numa banca de jornal, começa sua jornada assim:

Nilson (73 anos, morador do Gonzaga): Primeiro vou na loja do patrão para pegar o almoço dele e levar para a casa dele. Depois volto e vou para a banca - quando eu não fico lá, porque às vezes ele pede para ficar na loja. Aí eu num abro a banca. Aí fico lá até 6 horas, fecho e vou para casa, e a noite venho para cá.

E o Sr. Geraldo, que já está aposentado, contou que de manhã:

Geraldo, (61 anos, morador do Gonzaga): Caminho, leio, escuto música...

Juliana: E à tarde?

Geraldo: À tarde eu durmo um pouco acordo, sigo mais menos a mesma rotina e a noite a gente vem aqui no Gonzaga encontrar com este grupo de amigos, fico aqui até umas 10 horas e depois vou até o Boqueirão encontrar com outros amigos e converso até a meia noite mais ou menos.

J: E senhor está aposentado?

A: Estou aposentado.

J: E não trabalha mais? Qual foi sua profissão?

A: Eu fui portuário, eu conferente do Porto.

Nessa esquina não se reúne tanta gente como nas outras localizações observadas, e se parece mais com a muretinha do Canal Um com a Carvalho de Mendonça. Os senhores entrevistados eram todos das redondezas (Gonzaga e Boqueirão), e essa nos parece ser mais uma localização urbana de idosos de bairro: referencial social, central em seus pedaços, e acessível. Mais uma localização que recupera o prazer do encontro com seus pares, como era quando aquela quadra era a mais badalada de Santos, o melhor lugar para a paquera, a adolescência de muitos paulistanos veranistas... 


\subsubsection{E as mulheres?}

Os grupos de mulheres foram poucos na nossa pesquisa; somente dois: nas proximidades da Igreja São Judas Tadeu e na praia do Gonzaga. Nos bancos da calçada da areia, debaixo de uma árvore, logo ao lado do Posto 2 (posto dos salva-vidas), algumas senhoras perceberam que tomavam sol quase todos os dias no mesmo local. Agora elas marcam o horário para chegarem juntas. No dia em que as entrevistei estavam em seis: quatro viúvas e duas casadas. Todas moravam próximas da praia (no Gonzaga e no Pompéia).

Dona Frida, uma das viúvas, imigrou da Áustria para São Paulo, onde viveu a maior parte de sua vida. Hoje vive em Santos, na orla da praia, e está com 78 anos. Dona Célia, de 68 anos, é espanhola. Viveu 40 anos em Praia Grande e há três anos está em Santos, na Floriano Peixoto, próximo à praia, vivendo sozinha. Ela preferiu morar nessa rua porque assim está perto da residência de seus filhos e dos locais que gostava de ir. Sua atividade preferida é passear pelo Gonzaga nos shoppings, fazer compras e tomar sol na praia, como fazia naquele momento da entrevista. As atividades cotidianas das senhoras desse grupo eram praticamente as mesmas e não mencionaram freqüentar as atividades da terceira idade da prefeitura ou do SESC. Vale a pena reproduzir o trecho em que explicam como se conheceram e contam um pouco do seu dia-a-dia:

Célia: Esse grupinho aqui? Agora tem pouco! Tem dia que tem umas oito, dez, né? Hoje tem pouquinha!

Juliana: E como vocês começaram a se reunir aqui?

Frida: Aqui gente vinha se proteger do sol. Por isso todo mundo vinha aqui ... No calor o sol é muito forte, a gente fica até o meio dia...

Rosa: Ou então a gente vai trocando... [de ponto na praia]

Juliana: E como vocês se conheceram?

Frida: É só sentar aqui. Aqui se fala, conversa, já estamos amigas.

Célia: Vem uma, sentou do lado, puxou conversa, já era.

Frida: Simpatiza, vem outro dia, vem outro dia... já estamos amigas... 
Juliana: E vocês ficam conversando sobre o quê?

Frida: Ah... doença, comida, bobagens, novela, aí saem as bobagens... (risos)

Juliana: De manhã a senhora está sempre aqui na praia?

Célia: Isso.

Juliana: E de tarde passeando pela cidade...

Célia: Isso. Passeando, fazendo algum compromisso... Que a gente sempre tem, né?

Juliana: E quando a senhora vai passear a senhora vai pra onde?

Célia: Eu vou para o shopping.

Juliana: Shopping? Em qual shopping? Balneário, Miramar?

Célia: Os dois, é que eu procuro em tudo. Quando eu vou procurar um negócio, procuro no shopping todo até achar o que é melhor, o mais barato por aí...

Juliana: E senhora vai como?

Célia: A pé.

Juliana: E para a praia também?

Célia: Também.

Juliana: E a senhora?

Frida: É como a Rosa, arrumo a casa de manhã, venho aqui... Eu trago lanche; sou a única que come aqui, sou como uma nenê, trago banana, maçã, uva, sou a única que come... Depois vou pra casa esquento a comida - que já está pronta - vejo televisão, o repórter da Globo, ouço todas essas bobagens, depois lavo o meu pratinho, às vezes ponho na máquina porque uma vez por mês tem ligar porque se não enferruja. E depois continuo assistindo televisão (...) depois se tenho vontade, me visto e saio de novo. Assim é a vida... Outra vez lancho...

Rosa: E come... 
Frida: Ah, eu como! Eu vivo pra comer [risos]... Que podemos fazer? Eu gosto só de coisas boas...

(...)

Juliana: A senhora nasceu em Santos?

Frida: Não, nasci na Áustria. Eu sou de lá. Vim com meu marido em 49 para cá, em São Paulo. Eu morava lá no Paraíso perto da Paulista. Morei lá a vida toda. Meu marido se aposentou e meu filho inventou de morar aqui para aproveitar o mar ... Meu marido ficou muito doente e não aproveitamos nada. Por isso eu todo dia venho aqui, eu não quero entrar naquela vida ...

Apesar de variarem, às vezes, o local do encontro, é possível encontrá-las freqüentemente naquele banquinho (e com cadeiras de praia que trazem de casa) durante as manhãs entre segunda e sexta. Nesse exemplo podemos verificar que o encontro delas é proporcionado não só pela praia, mas pelo ambiente construído da praia: os bancos e a sombra das árvores do jardim. Elas estão unidas por uma mesma prática - tomar sol (ou curtir a sombra fresca) - e pela mesma localização urbana (aquele ponto acessível a pé a todas elas). Descobrindo seus hábitos cotidianos e suas histórias de vida, logo se vê que estão próximas também pelas suas condições de classe e de arranjo familiar. Nesse sentido, a localização residencial (que está relacionada com a localização de seus lazeres) denota um perfil sócio-econômico similar, como tentamos mostrar no capítulo anterior.

Andando pelo Marapé notei que a Igreja São Judas Tadeu reúne muitas senhoras. E já fora da Igreja, algumas conversavam antes de se despedirem. Esse grupo chamou-me atenção porque eram senhoras do segundo seguimento etário: três de mais de 80 anos e apenas uma de 75. Eram donas de casa que não saíam muito de casa, mas tinham uma participação efetiva na Igreja. Nesse sentido, podemos sugerir que a sociabilidade entre essas senhoras mais velhas, como já sugeriu Motta (2004) é mais restrita ao mundo familiar, privado, mas a Igreja, como um espaço público controlado com regras bem definidas de comportamento, onde elas têm uma importância conquistada pela eficácia de suas ajudas voluntárias nas atividades da paróquia, nos parece ser uma exceção. De fato, essas senhoras 
- que moram todas ali nas próximas quadras - ficam entre suas casas, a Igreja e a casa de seus filhos.

Entre todos que entrevistamos nas ruas, poucos tinham mais de 80 anos (na verdade cinco senhores e quatro senhoras apenas). Entre os idosos mais velhos, é menos freqüente sair de casa, seja por falta de disposição (saúde) seja por não cultivarem o hábito de sair todos os dias. Motta (2004), que estudou a sociabilidade entre idosos de Salvador, também afirma que a geração dos atuais idosos de 80 anos ou mais não participou do momento de transformação da velhice numa etapa libertária de realização de atividades prazerosas, aguardadas a vida toda. Os idosos mais velhos ainda cultivariam hábitos da velhice recatada. A imagem de um envelhecimento ativo trazido pela expressão terceira idade e as atividades engendradas por essa visão da velhice são menos aceitas por esse grupo porque estão menos "afinados com o tempo social que gestou esses programas para terceira idade (...) [São os idosos de menos idade] que gozam mais larga e amplamente dos benefícios desse fato social relevante e relativamente recente que é a aposentadoria (...) e são os que mais foram atingidos diretamente pela difusão do ideário feminista de emancipação, autonomia, e igualdade de direitos entre os sexos" (Motta, 2005, p.127). De fato, entre os idosos entrevistados, a grande maioria tem entre 60 e 70 anos.

Mas em todos os grupos, observamos que são as mulheres idosas que cada vez mais saem de casa e buscam novas experiências, sobretudo as viúvas e as que trabalharam profissionalmente. As aposentadas se destacam como a parcela que tem mais iniciativa de buscar novos conhecimentos, e de participar das atividades de voluntariado. São a maioria nas faculdades de terceira idade, na organização dos eventos beneficentes e estão muito presentes nas pastorais da Igreja Católica. Estela é um bom exemplo. Paulistana que reside a quatro anos em Santos e viúva há três anos e meio aposentou-se como professora de música. Depois de alguns meses trabalhando voluntariamente numa casa assistencial de educação de crianças portadoras de deficiência, foi convidada para ser contratada pela instituição. Como ela tinha outras atividades que gostava muito (faculdade da terceira idade, o coral da Igreja, e a alfabetização de adultos) ela recusou o convite. Ao contrário de boa parte dos aposentados, o que lhe falta não são atividades. 


\subsubsection{Adentrando a Ilha...}

Nos bairros da chamada Zona Noroeste (Rádio Clube, Saboó, Bom Retiro, Santa Maria, Castelo, Chico de Paula, Areia Branca, Vila São Jorge, Caneleira, Jardim Piratininga e São Manoel) cujas construções são mais pobres ${ }^{83}$ havia menos espaços para convivência (menos praças) embora essa região conte com o Horto Florestal. São também os bairros que têm menos população idosa.

Vimos que os idosos da Zona Leste, tanto dos bairros praianos quanto dos bairros interiores deslocam-se menos para outros setores de zonas urbanas da cidade além dos que eles vivem. Nesse sentido, os seus "pedaços centrais" são próximos aos seus "pedaços residenciais". Já os residentes da Zona Noroeste foram entrevistados, em sua maioria, na orla da praia e nas pracinhas de jogos do Campo Grande, Marapé, Vila Belmiro e Pompéia. Na própria Zona Noroeste, quando caminhei por lá, vi muito poucos. Um único ponto, além do Horto Municipal - podemos apontar - dentro das limitações de nossa breve pesquisa de campo - como local de encontro entre idosos: a Associação de Melhoramentos do Bairro do Bom Retiro, cuja diretoria era de senhores de mais de 60 anos. É comum no sábado ver homens idosos e outros um pouco mais jovens reunidos para conversar e beber, como num bar. No entanto, esta não é uma exclusividade do Bom Retiro: é muito comum as Associações de Melhoramentos dos bairros santistas serem geridas por idosos (homens principalmente) assim como as mulheres idosas liderarem pastorais nas igrejas católicas, como vimos na Igreja Nossa Senhora do Rosário de Pompéia e na Igreja São Judas Tadeu.

Conversamos com dois senhores no Horto Municipal, importante área verde da cidade localizada no Bairro Santa Maria, mas não encontramos uma roda de conversa por ali. O Horto é mais visitado para caminhadas matinais, como costuma fazer o Sr. João, 74 anos, morador do Morro da Nova Cintra (que não é perto do Horto a pé) e Dona Engracia, 61 anos, moradora do Saboó.

Dessa forma, os idosos da Zona Noroeste vão para as localizações urbanas de idosos da Zona Leste, mas o inverso não acontece. Outro exemplo desse deslocamento temos no circuito dos bailes de dança de salão: mesmo havendo um CECOM na Zona Noroeste,

\footnotetext{
${ }^{83}$ Embora cada vez mais essas casas estejam recebendo melhorias. Depois que receberam infra-estrutura urbana (calçamento, asfaltamento, energia elétrica, saneamento, etc.) esse bairros já tem terrenos disputados e aumento do valor venal, como mostrou Carriço, (2002).
} 
muitos idosos dessa área preferem freqüentar os bailes dos CECOMs Vila Nova (José Menino) e Isabel Garcia (Boqueirão), assim como o Baile do Extra (o supermercado). Quando indaguei porque se deslocavam, disseram que buscavam qualidade: a melhor aula, o melhor baile. No entanto, no baile do SESI (Bairro Chico de Paula) eles vão: pois de quinze em quinze dias é o único que acontece aos sábados ${ }^{84}$, e que é freqüentado pelos idosos que movimentam o circuito semanal. Então agora o SESI é local de encontrar "todo mundo": adquiriu a centralidade social que marca as localizações urbanas de idosos.

No entanto, basta caminhar para a zona central da cidade para encontrar aqueles que nem sabem o que é terceira idade. Homens com 65 anos e aparência de 75, que trabalham o dia todo e chefiam domicílios que abrigam filhos e netos. Nessas famílias, como a do Sr. Francisco, a renda do idoso é a única garantida todo o mês.

Pude entrevistar o Sr. Francisco em sua casa, um cômodo no Bairro Vila Nova. Além da sua esposa, morava com ele também a família do seu filho, e na época, estava para chegar a família da sua filha. Todos recém-chegados do Vale do Paraíba onde segundo eles não havia oportunidades de emprego. Com a chegada da filha, somariam dez pessoas em um cômodo, como se vivia em Santos há 130 anos atrás. Dos sete que moravam lá na época, somente o Sr. Francisco e seu filho tinham saúde e idade para trabalhar, pois a esposa do Sr. Francisco se cansava facilmente até mesmo nos trabalhos de casa ${ }^{85}$. Seu filho trabalhava como ajudante de obra com um contrato temporário, de forma que a única renda garantida mensalmente era a aposentadoria especial do Sr. Francisco, que não podia mais trabalhar como caminhoneiro por causa de um acidente que o tirou a visão de um olho. Por isso atualmente trabalha como catador de papel.

Quando o perguntei sobre a terceira idade, ele disse que não sabia bem o que era isso. Como estava há pouco tempo em Santos, perguntei se ele estava gostando da cidade, ao que ele disse que é um bom lugar. Não se referiu à praia em nenhum momento da entrevista, mas quis ressaltar que já tinha feito amigos (outros catadores de papel), que já tinha uma turma,

\footnotetext{
${ }^{84}$ O SESC também faz bailes de dança de salão aos sábados, mas somente quinzenalmente, de forma que nos fins de semana que não havia bailes no SESC, o baile do SESI ficava superlotado.

${ }^{85}$ A esposa do Sr. Francisco foi ao posto de saúde municipal (uma policlínica em Santos) por causa de seu mal-estar constante, mas não recebeu tratamento. Sua doença exigia remédios muito caros e que não iam poder curá-la; somente aliviar o sofrimento. O médico preferiu mandá-la para casa descansar, o que ela efetivamente fez antes desta dissertação se concluir...
} 
e que se precisasse, tinha quem o ajudasse; que se não tivesse dinheiro, podia comer sem pagar no bar da esquina onde já tinha feito amizade com o dono. E ainda, Santos era uma boa cidade porque nela seu filho havia conseguido finalmente arranjar um emprego com carteira assinada, e por isso a filha estava para chegar.

O Sr. Francisco veio para Santos porque tinha sido incentivado por alguns de seus companheiros (também do Vale do Paraíba) que foram pra Santos e conseguiram viver um pouco melhor. Nesse sentido, podemos vislumbrar nesse relato a hipótese de um provável fluxo de migração por redes sociais de população pobre idosa pra Santos. Chama nossa atenção que mesmo no caso do Sr. Francisco que está muito distante de qualquer vivência de terceira idade, a sociabilidade que ele conquistou também faz de Santos seu lugar preferido, e por ter já se inserido na turma que faz os "bicos", que mora e trabalha toda por ali, ele não procura, por enquanto, viver em outra área da cidade, como a Zona Noroeste, mesmo pagando por um cômodo o suficiente para alugar uma casa naquela região.

No pequeno bairro do Jabaquara, onde ficava antigamente o famoso Quilombo, a única idosa que vi na rua e consegui entrevistar foi Dona Cecília. Ela estava na esquina da sua rua esperando alguém; parecia estar voltando de algum lugar por perto quando a abordei. Depois de me apresentar e explicar meu interesse em conversar com pessoas com mais de 60 anos sobre Santos e o dia a dia, perguntei, já no final da entrevista o que ela achava da terceira idade. A sua resposta foi como um resumo de suas queixas da velhice que lhe era possível viver:

Cecília (72 anos, Jabaquara): Terceira idade é fogo na roupa! Não é muito bom não. O bom mesmo é já morrer e ir embora! Não é bom pensar assim, mas, às vezes a gente pensa. A gente não pede a morte para Deus. A gente não pôde pedir para vir, mas também não pode pedir para ir; tem que ser feito a vontade de Deus. Eu mesmo penso assim. Meu marido, ele sabe melhor que eu para dizer as coisas. Ele não faz nada... [vive doente] (...) Outro dia desmaiei, lembro que eram três horas da tarde. Sabe que hora fui acordar? No outro dia, na Santa Casa tomando soro. Aí fiquei perguntando por que eu estava ali, quem tinha me levado, por que estava tomando soro, 
o que tinha acontecido comigo... eu não estava bem, minha pressão abaixou...

Dona Cecília trabalhou sem registro como faxineira em casas de família durante muitos anos. Depois trabalhou numa empresa onde, registrada, se aposentou precocemente por causa de um acidente de trabalho ${ }^{86}$. Mesmo não podendo ficar em pé por muito tempo, ela cuida da casa, do marido, toma conta da neta enquanto sua filha trabalha e ainda vai comprar alguma coisa que precisa em casa por perto. Dona Cecília está longe de qualquer rotina que tenha a sociabilidade na agenda, e sua vida é no lar familiar. Terceira idade, para ela, é sinônimo de muita idade, e está longe de ser um período de descanso.

No centro, no primeiro bairro residencial de Santos, o Valongo, pode-se ver durante a tarde entre alguns caminhoneiros que esperam sua vez no Porto alguns poucos idosos caminhando pelas ruas ou em algum bar. Nessa área degradada, as únicas residências são os velhos casarões de outrora, hoje cortiços. Consegui apenas uma única e rápida entrevista com um ensacador aposentado de 80 anos, que mora num cômodo. Seu cotidiano é sempre por ali, fica perambulando pelas ruas conversando ora com um ora com outro... Ele não tem "atividades":

Jerônimo (80 anos, morador do Valongo): Eu não faço mais nada, 80 anos! Eu vou fazer o quê?

Juliana: E de tarde? O que fica fazendo?

Jerônimo: De tarde já é tarde...

Juliana: Onde o senhor gosta de ficar em Santos?

Jerônimo: Na Campos Melo... um outro lugar... Na praia já tive muito, agora não vou mais não quero mais saber de praia.

De maneira geral, nos bairros da zona central (Jabaquara, Caneleira, Centro, Valongo, Paquetá, Vila Nova e Macuco) e da zona Noroeste a maioria dos poucos idosos

\footnotetext{
${ }^{86}$ É interessante notar que entre nossos 45 entrevistados cinco mencionaram aposentadoria depois de acidente de trabalho: o Sr. Júlio, que foi ensacador no Porto e mora no Jardim Rádio Clube, o Sr. Francisco, que era caminhoneiro, que mora no bairro Vila Nova o Sr. Luís, representante comercial, que mora num apartamento pequeno na orla da praia do Embaré, a Sr. Cecília, supracitada e o Sr. Cláudio, portuário que freqüenta a Carvalho de Mendonça no cruzamento com a Bernadino de Campo e que não revelou onde morava. Note-se que destes, três pertencem ao Bloco Centro Zona Noroeste.
} 
que encontrei vive uma velhice sofrida, com doenças crônicas, e outros ainda trabalham, apesar de já estarem aposentados. Foram poucos os que disseram freqüentar as atividades da chamada terceira idade, no CECOM ou ir nos bailes de dança de salão. A maioria dos idosos entrevistados nessas regiões diziam não gostar desse tipo de atividade e nem do tipo de pessoas que freqüentavam o lugar. Eles tinham outros hábitos, como ficar cuidando da casa ou ver televisão. Na verdade poucos podiam participar dessas atividades, pois trabalhavam durante toda a semana (como os senhores da Associação do Bom Retiro, que só se reuniam no fim de semana) ou não tinham disposição física, como Dona Cecília, no Jabaquara.

Caminhando do centro para a orla, a partir da Avenida Conselheiro Nébias começamos a encontrar idosos nas ruas à medida que nos aproximamos da praia. Nos bairros da orla destaca-se o Embaré e o bairro da Aparecida no qual mais vimos idosos caminhando nas ruas do que em todas as outras áreas da cidade. Da mesma forma que nos bairros atravessados pelos canais de um a quatro, encontramos alguns estabelecimentos comerciais misturados aos quarteirões residenciais, como é característico de Santos. Mas a partir do Boqueirão, os serviços são mais requintados. Também nessa área já correspondente ao nosso "Bloco Praia", os idosos foram maioria nas ruas no meio das tardes e manhãs, passeando com seus cachorros, indo aos bancos, fazendo pequenas compras ou voltando da praia. Foi no Embaré (na verdade um dos maiores bairros de Santos) que vi o maior número de padarias, restaurantes, mercados e farmácias, algumas bastante requintadas. Nesse bairro é que fica o SESC, a uma quadra do Shopping Praiamar.

\subsubsection{Fora de casa e fora da rua}

No SESC encontrei muitos grupos de idosos reunidos para desempenhar alguma atividade lúdica. O SESC é um ponto de referência para encontrar idosos e ouvi isso de outros idosos entrevistados e de santistas residentes de diversas idades. Para freqüentá-lo é necessário ser sócio comerciário ou usuário. Os cursos são cobrados, mas têm preços promocionais para os sócios acima de 60 anos. O SESC funciona de terças a sextas das 13 às 22 horas; sábados domingos e feriados das 10 às 19 horas e não funciona às segundasfeiras. Uma vez associado, o idoso no SESC tem descontos para eventos e pode participar sem pagar mais nenhuma taxa adicional de algumas atividades direcionadas pra ele, como 
são as mesas de carteado e usar a piscina. Entre os cursos oferecidos pelo SESC e que têm "desconto para a terceira idade" estão o voleibol, natação, ginástica, dança de salão, teatro e os bailes quinzenais, além da área de convivência, um grande saguão com sofás para leitura e conversa.

Geralmente santistas ou residentes em Santos há mais de dez anos, os idosos que freqüentam o SESC costumam ir a pé ou de ônibus e moram - a maioria dos entrevistados nessa pesquisa - nos bairros da orla da praia. De manhã vão à praia e de tarde ao SESC; às vezes variando com um passeio no Gonzaga, ou no shopping que fica ao lado do SESC. Quase todos estão aposentados e já pararam de trabalhar, porém há poucos ainda que trabalham meio período.

As áreas residenciais desse grupo fora muito parecidas com a dos idosos que encontramos na praia, mas há muitos de São Vicente, Praia Grande e de outros bairros como Campo Grande e Vila Mathias.

Os idosos encontrados no SESC pareciam gozar de boa saúde. Eram animados e tinham muito prazer em dar a entrevista. Cuidar da saúde era parte do dia a dia deles, mas o cotidiano das tarefas do lar foi menos presente nos relatos desses entrevistados, que fizeram muitos elogios ao SESC e disseram passar a maior parte do tempo por lá. Nessas entrevistas foi fácil esticá-las e partir para uma conversar descompromissada sobre envelhecimento e a cidade de Santos. A opinião de quase todos é a de que Santos é a cidade certa para envelhecer, mas mostraram também preocupação com os jovens, pois acompanham a dificuldade dos netos e filhos em arranjar bons empregos. Sobre a terceira idade, novamente o termo traz a idéia da velhice decadente, e sempre que se iniciava o assunto, as primeiras frases vinham no sentido da negação:

Afonso: Não... Sabe o que é que é, eu estou na terceira idade, mas me sinto muito bem.

Juliana: É? E o que é Terceira idade para o senhor?

Afonso: Terceira idade é quando você já se sente só, que precisa de ajuda dos outros, eu não preciso de nada. Terceira idade só na idade. 
Não estariam na terceira idade porque estavam plenamente ativos, ao mesmo tempo que diziam que essa era a melhor fase da vida. A conversa com o casal de aposentados que abordei na área de convivência do SESC é bastante exemplar:

Juliana: E esta história de terceira de idade, o que é pra vocês? Vocês sentem que estão na terceira idade?

Paulo: Sim, sim, eu mim sinto na terceira idade... Na verdade eu me sinto como se tivesse na segunda...

Lúcia (66 anos, Embaré): Não. Sabe Juliana, eu vou à hidroginástica e faço direito - a maioria das pessoas faz tudo errado. Eu nado, sempre nadei, então eu me sinto ótima, apesar dos problemas que eu tenho (pressão alta, essas coisas...), me sinto muito bem! Eu gosto de fazer crochê, eu gosto muito de ler...

Juliana: Isso significa o quê? Que você não é da terceira idade?

Lúcia: Não. Agora se me olho no espelho eu sinto realmente que sou da terceira idade... (risos)

Paulo: Agora eu acho que as pessoas podem estar na terceira idade mesmo fazendo as coisas ... Terceira idade não é ficar deitado numa cama, sentado como uma concha olhando a vida...

Lúcia: Não, às vezes eu tenho preguiça. Eu gosto de ver filme e a noite ele vai dormir mais cedo; é bom porque levanta mais cedo, porque a gente gosta muito de andar. Agora tem gente, a ex-mulher dele, não anda! Fica o dia inteiro em casa fumando... Não pode! Tem que sair...

Paulo: Espera um pouco, não é porque a pessoa já está com uma certa idade, com os 70 anos, que não tem possibilidade... Tem gente que bateu um ventinho já se cobre todo, não sai de casa...Eu acho isso mesmo...

Lúcia: Eu gosto de comer bem, de beber cerveja, de tomar uma caipirinha... Ah é, e de viajar! Viajamos bastante.

Mas é o mesmo casal que lembra:

Lúcia: Agora me deixe falar uma coisa que é fundamental: depende do poder aquisitivo. Aquela pessoa de classe média, classe média alta, ela pode 
desfrutar, ela pode viajar... agora aquela pessoa pobre, que tem que sustentar filhos e netos, ela não pode passear, ela cada vez mais vai ficando cansada, mais estressada...

Paulo: É.

Lúcia: É fundamental, infelizmente.

Nessa pesquisa, os entrevistados do Bloco SESC foram os que apresentaram a concepção mais positiva do envelhecimento, como uma ótima fase da vida de realizar sonhos e divertir-se. No SESC, assisti também a um desfile de moda por ocasião do Dia das Mães, e praticamente todas as modelos tinham mais de 60 anos. Segundo a diretora da agência de modelos By Clô que organizou o desfile, foi fácil a adesão das lojas à iniciativa. Na sua agência, que oferece cursos de modelo e etiqueta, as alunas de mais de 60 anos é que sugeriram a existência de um curso do tipo voltado para elas. A iniciativa foi das senhoras ${ }^{87}$.

Oferecendo praticamente as mesmas atividades do SESC há o CECOM (Centro Comunitário da Terceira idade). Criado em 1991, o CECOM, assim como a República de Idosos, é um projeto pioneiro da prefeitura de Santos de oferecimento de atividades alternativas para a população idosa, com vistas ao seu bem-estar e à sua integração social. Nos CECOMs as vagas são limitadas, mas o acesso é livre, bastando cadastrar-se e fazer a matrícula. Para os bailes a participação é totalmente aberta, sendo exigido somente que se tenha mais de 60 anos no caso do CECOM Isabel Garcia. No CECOM Vila Nova não há nem a restrição de idade.

Os bailes, assim como outras atividades, são regulados pelos próprios freqüentadores. O tempo (das 14:00 ás 17:00) e o espaço são oferecidos e delimitados pelo CECOM, mas a preferência das músicas, a entrada de pessoas estranhas é vigiada pelos próprios frequientadores. Embora o CECOM seja um espaço público com regras próprias institucionais, ele é apropriado pelos idosos que interferem muito no seu funcionamento. A restrição à idade no baile do CECOM Isabel Garcia foi um pedido das senhoras, que não gostavam da concorrência de mulheres jovens (em todos os bailes de salão sempre há muitas

\footnotetext{
${ }^{87} \mathrm{Na}$ nossa pesquisa de campo, entre as diversas atividades observadas (dança, coral, trabalho voluntário) as idosas demonstraram muita autonomia e iniciativa nas atividades que realizam. Assim foi com o Coral da terceira idade da Unisantos, que foi antes um grupo de senhoras que se reuniram para cantar e recuperar, algumas, os talentos musicais dos seus tempos de rádio. Depois do sucesso do coral é que a UNISANTOS decidiu abrigá-lo e profissionalizá-lo com a contratação de uma maestrina.
} 
damas para poucos cavalheiros). Já no CECOM Vila Nova, por uma opção da diretoria estimulou-se sempre a integração geracional, e por isso há incentivos para que os idosos tragam familiares aos bailes. Essa é uma nova diretriz administrativa recente da prefeitura, que visa fortalecer a família e a comunidade, e por isso a mudança do nome: de "centro de convivência", para "centro comunitário", como me explicou a diretora do CECOM Vila Nova.

São nesses espaços institucionalizados e apropriados pelos idosos que encontrei muito mais mulheres do que homens. Nas turmas da Universidade da Terceira Idade da Universidade Católica de Santos (a primeira a oferecer a faculdade da Terceira Idade em Santos) as mulheres são quase o total de alunos. E tanto no SESC quanto no CECOM (talvez mais no CECOM) as mulheres são as grandes freqüentadoras. Nos bailes, depois das aulas de ginástica, na lanchonete do SESC é que estão as rodas de conversa de senhoras.

\subsubsection{Circuitos}

Na nossa pesquisa notamos que há grupos de idosos que se formam por causa de uma atividade preferida, como a dança de salão, o canto coral, e o trabalho voluntário. Esses grupos se reúnem em alguns lugares quase diariamente, seguindo uma agenda de encontros. Talvez estejamos diante de circuitos, pois cada um deles deixa o seu "pedaço", mas não se encontra somente em um outro pedaço central, mas sim em vários locais acessíveis e propícios para a prática que querem realizar. Esse nos parece ser o caso dos freqüentadores dos bailes de dança de salão, dos ensaios dos corais e das casas assistenciais e hospitais (o voluntariado) - os três circuitos que identificamos. Na maioria dos bailes e ensaios que observamos em vários lugares, os participantes foram quase sempre os mesmos, e nas entrevistas as senhoras que faziam trabalhos voluntários ajudavam mais de uma instituição. Embora essa situação não seja um exemplo fiel da categoria "circuito", usaremos o termo para nos referir a essa prática, pois são deslocamentos cíclicos para locais acessíveis a eles em termos de tempo e custo, definidos pelas atividades que praticam, ou seja, são circuitos entre locais, alguns transformados aos poucos em localizações urbanas de idosos.

Na nossa pesquisa optamos por acompanhar de perto o circuito da dança de salão, que a nosso ver, é o maior e o mais movimentado. Todos os dias da semana têm um baile: 
- Segunda-feira: Clube na Rua Cunha Moreira com a Rua Júlio Conceição (não souberam me dizer o nome do Clube), bairro Encruzilhada, das 15:00 às 18:00 horas;

- Terça-feira: Hipermercado Carrefour, Bairro Jardim Independência, em São Vicente próximo à divisa com Santos, das 15:00 às 18:00 horas;

- Quarta-feira: Hipermercado Extra, na Rua Pedro Américo, Bairro Campo Grande, das 15:00 às 18:00 horas;

- Quinta-feira: CECOM Isabel Garcia, na Rua Barão de Paranapiacaba, Bairro Encruzilhada, com aula das 15:00 às 16:00 e baile até as 17:30 horas;

- Sexta-feira: CECOM Vida Nova, na Avenida Presidente Wilson, Bairro José Menino, das 14:00 até as 17:00 horas;

- Sábado: SESI (Serviço Social da Indústria), na Avenida Nossa Senhora de Fátima (bairro Chico de Paula), das 14:00 às 18:00 horas;

- Domingo: Fonte do Sapo, na praia da Aparecida, das 19:00 às 22:00 horas.

Todos esses bailes são gratuitos, e a maioria, como se pode notar, é na Zona Leste de Santos. São os aposentados de classe média (daqueles $60 \%$ que percebem entre três e dez salários mínimos) que moram nos bairros intermediários os seus maiores freqüentadores. Eles vão de ônibus ou a pé, e costumam sair de suas casas para o baile. Em alguns desses locais os bailes formaram localizações urbanas de idosos, como é no caso do Extra, do Carrefour e da Fonte do Sapo. Nesse sentido o baile do Extra de Santos merece atenção, pois foi o primeiro supermercado no Brasil a oferecer um baile no seu espaço, ficando conhecido em toda a cidade como lugar de ver idosos.

\subsubsection{O Baile do Extra}

Há seis anos, na época de comemorar o aniversário de um ano do supermercado, a diretoria decidiu fazer um grande evento. Nessa época a empresa fez uma pesquisa sobre seus clientes do período diurno e descobriu que de cada dez clientes, quatro eram idosos ${ }^{88}$.

\footnotetext{
${ }^{88}$ Não tivemos acesso ao relatório dessa pesquisa, muito menos à diretoria, procurada muitas vezes por telefone e pessoalmente, infelizmente inacessível. As informações que constam aqui são as que obtivemos
} 
Como se pensava que não havia muitas alternativas de diversão para as pessoas da terceira idade, decidiram fazer o evento direcionado para eles. $\mathrm{O}$ baile aconteceu dentro do espaço do supermercado e fez muito sucesso. Os elogios recebidos por meio da caixa de sugestões foram tantos, que o supermercado passou a promover o baile semanalmente.

O baile acontece num espaço que serve de passagem entre o estacionamento e o espaço da loja onde estão as mercadorias. Em torno dele há uma lavanderia de lavagem a seco, um salão de beleza, uma banca de jornal, um quiosque do Mc Donalds, outro que vende quadros, um estande de venda de filtros d'agua, um estande maior que vende aquários, uma máquina de locação de DVDs instalada recentemente, e já na saída lateral uma ótica. No primeiro ano de inauguração desse supermercado, havia somente a lavanderia, o salão, a loja de aquários e uma farmácia.

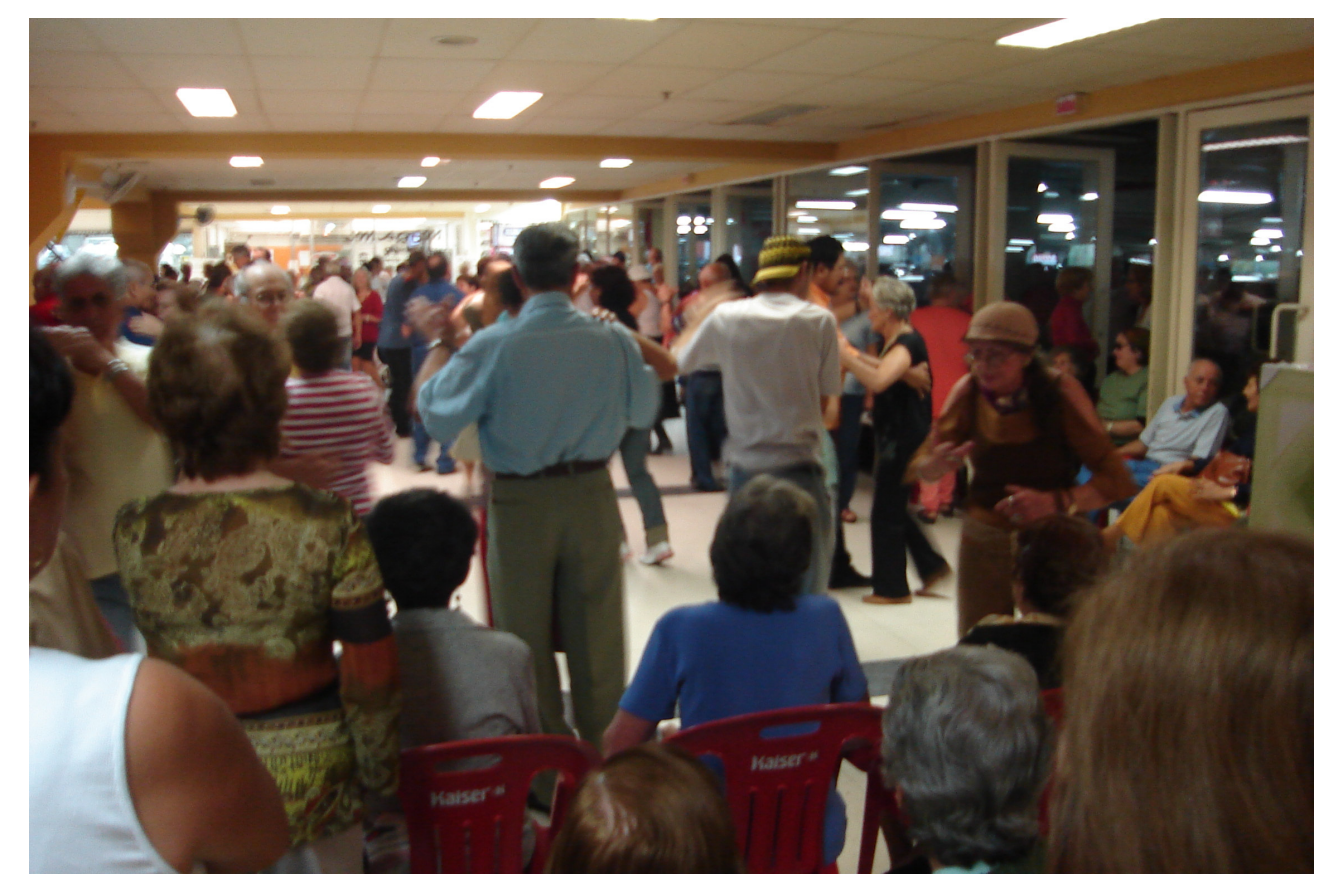

Figura 14: Baile do Extra, numa tarde chuvosa de quarta-feira: neste dia havia menos gente do que de costume. Foto da autora, outubro de 2006.

em conversa com Jonathan, o ex-funcionário que cuidou do baile desde o início e que hoje trabalha como prestador de serviço ao supermercado e como DJ para outros bailes de dança de salão. No entanto, em contato eletrônico e por telefone com a assessoria de imprensa do Grupo Pão de Açúcar em São Paulo obtivemos autorização para fotografar o baile. 
Rita, uma das veteranas do circuito da dança, é quem organiza o espaço, distribuindo as cadeiras em roda e delimitando o espaço da dança. As cadeiras são muito disputadas, e por isso os participantes chegam cedo. Não é permitido reservar cadeira para algum amigo que queira chegar mais tarde. Durante o baile, todo o espaço tanto no círculo interno às cadeiras quanto ao redor fica ocupado. A passagem que fica entre o estacionamento e a esteira rolante de acesso à loja é suficiente para passar um carrinho de cada vez.

Entre os participantes muitas donas de casa viúvas, aposentados, e muitos que ainda trabalham e apressam o serviço para sair mais cedo e ir dançar. Os que fazem isso geralmente trabalham informalmente (vendedores ambulantes, corretores de imóveis, vendedores de seguro, etc.). E há também alguns casais que estão perto mas ainda não chegaram aos 60 anos.

É muito freqüente o casal do aposentado com sua esposa, como Ruth e Silvio. Ela é dona de casa e ele é aposentado há 15 anos. Moram no Campo Grande, bairro residencial de classe média a poucas quadras do supermercado. Seus filhos já estão casados e vivendo em suas próprias casas, com filhos adolescentes que não precisam mais da presença constante dos avós para tomar conta e ir buscá-los na escola. Então, não restaram muitos afazeres a esse casal. Ruth resume: "Não temos nada pra fazer à tarde, os netos já estão grandes, então todo dia a gente vai dançar (...) Tem que sair de casa, ficar parado é que não dá”.

É de praxe chegar ao baile e cumprimentar Jonathan, que é muito querido pela maioria deles. O cumprimento é feito sem que se tenha que parar de dançar, numa demonstração de domínio do corpo e da dança. Nos bailes de maneira geral os idosos provam a eles mesmos e, no caso do Extra, exibem ao público como driblam com maestria os fatores que fazem da velhice um tempo temido: a perda dos domínios corporal, mental e emocional. Ao demonstrar agilidade na dança, elegância e alegria provam - como sugere Featherestone (1998) - que eles têm essas três principais competências (controle do corpo, da emoção e habilidades cognitivas) para serem considerados pessoas capazes, "confiáveis, aceitas, com plenos direitos de cidadão". No baile mostram para toda a platéia assídua e para os todos os clientes do supermercado (que são obrigados a passar pelo baile para ter acesso à loja) sua juventude. Como diz Silvio: “Tenho 70 anos, mas aqui tenho só 30”. 
A platéia é muito maior que a pista de dança, e outro ambiente se forma entre os que assistem o baile: são os outros freqüentadores assíduos. Há pessoas de todas as idades nesse público, mas a maioria aparenta ter mais de 60 anos. As senhoras balançam a cabeça e o corpo, desejosas de dançar. Alguns senhores olham sérios, com compras no carrinho, e fazem comentários entre eles. Há os casais de idosos que indo embora com as compras, param antes para observar; e há as pessoas que moram por perto e costumam aparecer por ali para curtir as músicas e o ambiente. Conversei com um senhor que costumava fazer compras e assistir um pouco do baile, antes de voltar pra casa. Ele, que tinha 70 anos, disse que era legal ver "esse pessoal da terceira idade". Os clientes de outras idades elogiam o supermercado, principalmente os clientes turistas.

A platéia, assim, é diversificada, mas não vimos muita conversa entre jovens e velhos. A sociabilidade nesse baile é intra-geracional, tanto entre os que dançam (todos idosos) quanto entre os que assistem. Há rodas de conversa na platéia mais próxima à pista, e parecem ser um público cativo, pois são pequenos grupos de senhoras mais velhas sentadas, ou seja, que chegaram cedo e reservaram seu lugar. Em outros dias vi os mesmos grupos de senhoras conversando praticamente no mesmo local; parece que elas se encontram para conversar no baile e já sabem que não vão dançar (ou não querem dançar). Entre elas há uma senhora de 90 anos que desde o primeiro baile sempre está lá para assistir. Ela já não tem condições de dançar, mas é conhecida e querida por todos. Uma vez seu aniversário foi comemorado lá.

Na pista de dança o número de homens é sempre menor que o de mulheres, assim como na platéia, onde essa desproporção é um pouco menor. Nos bailes que participei duas senhoras dançavam sozinhas (e faziam questão de continuar assim). A pista de dança é sempre cheia, e fica ainda mais quando está tocando forró, samba de gafieira ou pagode, que são os ritmos preferidos. As músicas mais antigas e os boleros são tolerados por pouco tempo; logo algum casal vem pedir ao DJ para animar mais, pois assim poderão também colocar em prática os complicados passos que aprenderam nas diversas aulas de dança de salão oferecidas pela cidade.

Todos dançam muito satisfeitos e sorrindo, principalmente nas músicas mais agitadas, arriscando passos aéreos até. Dançar é um grande prazer, logo se vê pelas suas expressões 
faciais. O ambiente é como num baile colegial, e há muita paquera e casais de namorados (até relacionamentos extraconjugais). Dali já saíram dez casamentos, contou-me o DJ. E há a turma dos amantes da dança, como algumas viúvas que dançam com seus parceiros fixos de dança, senhores que também chegaram sozinhos e se enturmaram.

O baile vai das 15:00 às 18:00, mas por volta de 17:15 Rita já começa a guardar as cadeiras e a maior parte dos participantes vai embora: essa é a hora em que muitos deles têm que ir buscar o neto na escola. Alguns depois sobem à esteira rolante e vão comprar algo que está faltando em casa, ou para o lanche da tarde, para o neto, etc. Ao invés de irem à quitanda do bairro, já deixavam essa compra para depois do baile, no supermercado.

Mas a festa continua. Depois do baile, o supermercado oferece ainda um músico tocando ao vivo até às $20 \mathrm{~h}$, no andar superior onde estão as mercadorias, a praça de alimentação e algumas poucas lojas. Há espaço, mas menos casais dançavam, pois a maioria já tinha ido embora. Esse parece ser o momento de conversar e descansar consumindo um cafezinho, um refrigerante ou uma cerveja. Nesse momento há também algumas senhoras que vem exclusivamente para assistir aos que dançam. Chama atenção uma senhora maltrapilha com um carrinho vazio parada em pé observando o baile. E outra, que nunca dança e fica muito irritada quando alguém ocupa uma mesa que atrapalha sua visão dos casais que dançam. As duas não estavam no baile à tarde e pareciam ter chegado para aquele momento de "happy hour".

Nesse baile, e principalmente nesse happy hour após o baile, pode-se identificar as "panelinhas" (grupos de amigos), rostos que se pode ver depois em outros bailes da cidade. Eles se reúnem pra dançar, mas também apenas por se reunir e ser uma turma, como Silvio faz questão de declarar: "Nós aqui somos uma família".

O baile do Extra é o preferido dos entrevistados do circuito de dança de salão. Aqui, além da dança, eles têm a platéia de idade variada, o espaço para conversar tranqüilamente e fortalecer seus vínculos de amizade, e podem interferir na organização fazendo críticas e sugestões. Mas a nosso ver o sucesso desse baile se explica também por esse ser o caso mais claro de produção de uma localização urbana de idosos. Um baile que acontece num espaço que servia somente de passagem entre o estacionamento e a loja, que tinha poucas vitrines, mas que agora é um espaço valioso de prática de uma atividade de um grupo específico: é o 
lugar do baile da "Melhor Idade". Uma tradição já se forma em torno desse baile; é o principal dentro do circuito, e de acordo com nossa breve observação participante, o mais lotado. Foi depois dessa iniciativa que o Carrefour passou a oferecer um espaço com um DJ e mais: um pequeno lanche de chá com bolachas. Tudo de graça para os idosos. Recentemente, o Extra contratou um "personal dancer" ${ }^{89}$ : um dançarino profissional para dançar gratuitamente com as senhoras que não tem parceiro.

No Extra é possível ver idosos durante todo o dia e em todos os dias da semana, mas a parte da manhã é o período mais freqüentado. Segundo eles, é bom ir cedo porque as frutas são mais fresquinhas, embora, na verdade a reposição dos hortifrutigranjeiros aconteça durante todo o dia. Jonathan acha que eles vêm de manhã por uma questão de hábito e para se encontrarem.

Os idosos desse circuito, assim como a maioria dos outros entrevistados, também vêem na velhice uma experiência decadente, e a expressão "terceira idade" é apenas mais uma para falar de "velho". Assim, eles não gostam da expressão, e dizem que ser velho não é mais que um pensamento, uma atitude, e por isso podem não ser velhos se quiserem. "Melhor Idade" sim, é vista como uma expressão mais adequada - já que se tem que usar alguma - pois remete àquele que "já se preocupou com o que tinha que se preocupar e então você já passou daquele período, dessa fase...”.

Para esses grupos de praticantes de atividades, mais do que para outros blocos de entrevistados, o importante é sair de casa, pois é fora de casa que se sentem jovens. Encontramos esse sentimento de juventude ao praticar uma atividade também entre as senhoras que cantavam em corais. "Alegria para mim é quanto eu tô na rua!", disse uma delas. Os idosos dos circuitos também foram os que mais fizeram questão de dizer que tinham muitos amigos. Assim, sair de casa não traz somente o prazer de dançar, cantar e ajudar alguém, mas também “o ambiente ideal” do qual falava Simmel, uma turma, ou, como gostam de dizer, "uma família", enquanto a realidade do orçamento apertado, do convênio

\footnotetext{
${ }^{89} \mathrm{Na}$ dança de salão quando o número de damas é muito maior que o de cavalheiros - que é o que acontece em quase todo baile de dança de salão de qualquer idade - há espaço para os "personal dancers": cavalheiros que podem ser contratados por uma dama (ou por várias damas que fazem rodízio entre si) para dançar durante todo um baile. Eles são pagos por baile e o serviço pode custar entre 60 e 200 reais, de acordo com a habilidade na dança do dançarino.
} 
médico insuficiente, dos problemas financeiros dos filhos que fazem parte hoje dos problemas da velhice, ficam em casa.

$$
* * *
$$

Nesse capítulo procuramos observar como se dão a permanência e os deslocamentos no espaço intra-urbano e como o uso de certas localizações urbanas estão presentes no cotidiano dos idosos de Santos. Procuramos também relacionar essas atividades e usos do espaço com as suas maneiras de encarar o envelhecer e com a noção tão propagada de “terceira idade". Durante essa tarefa nos deparamos com algumas questões importantes no tocante à definição do processo atual de envelhecimento do trabalhador, que passa a ser identificado como aposentado, quando ele próprio ainda se identifica como trabalhador, ou ainda mais arbitrariamente à sua auto-imagem - passa a ser identificado como "terceira idade”. Essa e outras questões - como a dificuldade de aceitar a possibilidade de usar seu próprio tempo sem ter que fazer alguma coisa "útil" - não tiveram desenvolvimento nesse trabalho, ficando apenas como hipóteses sugeridas para outros estudos.

As conclusões desse último capítulo se confundem com as de todo o trabalho, de forma que as deixamos para as considerações finais. 


\section{CONSIDERAÇÕES FINAIS}

Esse trabalho tentou compreender o envelhecimento populacional da cidade de Santos-SP e o cotidiano da sua população no seu espaço intra-urbano. Por meio do estudo da formação da estrutura urbana de Santos, de entrevistas semi-estruturadas e de uma reflexão sobre a sociabilidade na aposentadoria, sugerimos que a maioria da população idosa santista que tem autonomia física e certa autonomia financeira se faz mais presente em certos espaços da cidade do que em outros, conforme a lógica estrutural que organizou as áreas residenciais e as localizações urbanas na cidade. O estilo de vida engendrado durante os anos em que foram trabalhadores e o ideal cada vez mais socializado de um envelhecimento autônomo faz com que, para eles, o segredo do bem envelhecer seja cada vez mais se abrir para o mundo de fora de casa. O uso de pontos do espaço intra-urbano por esses idosos como local de permanência e de sociabilidade - não só de rápida passagem marcam-nos como localizações urbanas de idosos, conferindo uma nova identidade à cidade, à velhice e aos próprios idosos.

Com suas presenças ativas, alegres, e algumas vezes pretensamente joviais, esses idosos fornecem argumentos em forma de imagens às concepções positivas do envelhecimento sugeridas pelas políticas públicas e pelo mercado, como a "terceira idade". Mas no exame do acolhimento dessa expressão pelos senhores e senhoras encontrados nas localizações urbanas de idosos, descobrimos que ela não faz parte do discurso das pessoas dessa faixa etária em diante, que preferem não se rotular, embora as principais instituições voltadas para uma clientela de mais de 60 anos utilizem essa expressão e outras equivalentes.

A especificação de atividades dirigidas para pessoas com mais idade, e o uso de uma denominação para designá-las colocam-nas em evidência como uma parte separada da sociedade. A resistência de alguns a freqüentarem "as atividades da terceira idade" pode ser atribuída ao fato de que eles não se colocam nessa parte deslocada e especial, mas sim como integrantes da teia de relações cotidianas, como qualquer outro cidadão, seja de idade avançada ou não.

Levantamos algumas questões que cremos merecer apreciação de futuras pesquisas, como: a migração intra-urbana de idosos dos bairros interiores para os bairros praianos; o possível fluxo migratório de população idosa pobre de outras regiões do Estado de São 
Paulo para Santos; a criação de um setor residencial de alta renda na Ponta da Praia com população idosa fazendo parte dele e reforçamos a hipótese de entrada de migrantes idosos paulistanos e do interior do estado de São Paulo na cidade para ocupar apartamentos outrora de segunda residência. Acreditamos que esse fenômeno migratório acontece também em Praia Grande, onde há muitos apartamentos de segunda residência, mais acessíveis financeiramente que os de Santos.

E além das questões apontadas no final do último capítulo, sugerimos uma afinidade eletiva entre a sociabilidade definida por Simmel e a aposentadoria, mais especificamente daquele que não volta a trabalhar. O mundo ideal da sociabilidade pode ser um caminho para re-adquirir um papel numa nova cena, principalmente para os homens idosos, menos ambientados com o mundo doméstico, domínio feminino nas gerações idosas mais idosas.

Neste mesmo contexto, percebemos que a maioria de idosas viúvas e aposentadas acentua o caráter libertador e prazeroso da imagem do envelhecimento santista, pois são as mulheres as que têm mais projetos e sonhos engavetados por antigos constrangimentos sociais, preconceitos e falta de independência financeira. Sem o peso da responsabilidade de cuidar de um lar, resolvem ir em busca de realizar seus sonhos, para preencher também a falta de um cotidiano a dois, no caso das viúvas. De maneira geral, foram as mulheres idosas as mais atuantes nas atividades lúdicas que observamos como os corais, a dança de salão, e estão mais presentes nas universidades de terceira idade, no trabalho voluntário em hospitais e creches assistenciais, e participam mais dos grupos que fazem viagens turísticas, embora também muitas idosas estejam cumprindo o papel de cuidadoras. Como o intervalo etário da categoria "idoso" já chega a abarcar 40 anos, é possível encontrar idosas cuidando de suas mães, como é o caso de muitas santistas.

Em Santos, a tendência de concentração social dos idosos nos bairros ricos da cidade e as localizações urbanas de idosos fazem a propaganda da melhor cidade para a "terceira idade”, mas mascara a existência de uma velhice sofrida em bairros pobres. Minoria numérica que são, escondidos nos cortiços da região central da cidade, ficam ainda menos visíveis, carecendo de condições mínimas de sobrevivência - uma aposentadoria digna, atendimento rápido e suficiente em postos de saúde, etc., mais urgentes que bailes na praia e 
ginástica 90 . E mesmo nos bairros “intermediários” (geográfica e economicamente), muitos idosos que freqüentam regularmente os bailes e a praia não têm condições de ter um bom convênio médico e não contam com atendimento emergencial satisfatório dos hospitais da cidade.

Ainda assim, por terem saúde para sair de casa estão em plena atividade, trabalhando, freqüentando a praia e os bailes. É a necessidade de continuar em frente que não impede aqueles que têm autonomia física de buscar diversão e amigos. Ao contrário, é para esquecer os problemas do lar que muitos saem e aproveitam os encontros - na rua, na praia, na praça ou simplesmente fora de casa - que, na maioria, ainda são de graça. E a produção de localizações urbanas de idosos continua a acontecer.

\footnotetext{
${ }^{90}$ Mas, a nosso ver a melhoria das condições de vida dessa população depende não só de ações setoriais (política para idoso), mas também da melhoria dos serviços públicos essenciais à toda a população, como a saúde e a habitação, e fundamentalmente, de uma melhora da remuneração da aposentadoria.
} 


\section{REFERÊNCIAS BIBLIOGRÁFICAS e BIBLIOGRAFIA CONSULTADA}

ALTHUSSER, Louis. Aparelhos Ideológicos do Estado, Editora Graal, Rio de Janeiro, 1983.

ANDRADE, Wilma Terezinha de. O Discurso do Progresso: A Evolução urbana de Santos 1870-1930. Tese de Doutoramento em História Social, da FFLCH-USP, São Paulo, 1989.

,Wilma Terezinha de. Mosteiro da ordem de São Bento. Santos, S.N, 1981

.Palestra proferida em 25 de agosto de 2005 na CEV (Comissão Especial de Vereadores). Disponível em: http://www.canaisdesantos.com.br/historia.htm Acesso em: 24 de julho de 2006.

ARAÚJO FILHO, José Ribeiro. "A expansão urbana de Santos" In: DEPARTAMENTO DE GEOGRAFIA DA FACULDADE DE FISOLOFIA E CIENCIAS HUMANAS DA UNIVERSIDADE DE SÃO PAULO. A Baixada Santista, aspectos geográfico. Vol. 3: Santos e as Cidades Balneárias. Edusp, 1965.

ARENDT, Hannah. A Condição Humana. Forense Universitária, 1997, Rio de Janeiro.

ASSOCIAÇÃO DOS EMPRESÁRIOS DA CONSTRUÇÃO CIVIL DA BAIXADA SANTISTA, Introdução à Formação Econômica da Baixada Santista. Gráfica da PRODESAN, Santos, 1984.

BARRETO JÚNIOR, Irineu Francisco. Poder local e politica: a saúde como lócus de embate na cidade de Santos-SP. Tese de doutorado em Ciências Sociais defendida na Pontíficia Universidade Católica de São Paulo (PUC-SP), São Paulo, 2005.

BARROS, Miriam M. Lins.(org.) Velhice ou Terceira Idade? Ed. FGV, São Paulo, 2000.

. "Velhice na Contemporaneidade" In PEIXOTO, Clarice (org.) Família e Envelhecimento. Editora da FGV, Rio de Janeiro, 2004.

"Envelhecimento, Cultura e Transformações Sociais" In PY, Lígia et al (orgs.) Tempo de Envelhecer: percursos e dimensões psicossociais. Nau Editora, Rio de Janeiro, 2004.

BERCOVICH, Alicia \& MASSÈ, Gladys. Descontinuidades Demográficas, Onda Jovem e mercado de trabalho: uma comparação entre Brasil e Argentina. Trabalho apresentado no I Congresso da Associação Latino Americana de População realizado em Caxambu - MG, de 18 a 24 de setembro de 2004. 
BERQUÓ, Elza. "Considerações sobre o envelhecimento da população no Brasil" In: NERI,Anita e DEBERT, Guita (orgs), Velhice e Sociedade, Campinas: Ed. Papirus, 1999. p.11-39.

BERQUÓ, Elza. e BAENINGER, Rosana. "Os idosos no Brasil: considerações demográficas.” Campinas. Textos NEPO 37, outubro 2000.

BEAUVOIR, Simone de. A Velhice. Difusão Européia do Livro, São Paulo, 1970.

BOSI, Ecléa. Memória e Sociedade: lembranças de velhos. Cia das Letras, Rio de Janeiro, 1995.

BOURNE, Larry. Internal Structure of the City: readings on space and environment. Oxford University Press, New York, 1971.

BRASIL. Lei n. 10.741, de $1^{\circ}$ de outubro de 2003. Estatuto do Idoso.

BRASIL. Lei № 8842 de 04 de janeiro de 1994. Política Nacional do Idoso.

BRASIL. Decreto-lei No. 53.831 de 25 de Março de 1964. Dispõe sobra a aposentadoria especial instituída pela Lei 3087 de 26 de agosto de 1960. Disponível em http://www.planalto.gov.br/CCIVIL_03/decreto/D53831.htm.

BRASIL. Lei No 3087 de 26 de agosto de 1960. LOPS - Lei Orgânica da Previdência Social.Disponível em http://www81.dataprev.gov.br/SISLEX/paginas/42/1960/ 3807.htm

BURGESS, Ernest. "O crescimento da cidade: introdução a um projeto de pesquisa", traduzido de The City - University of Chicago Press, 1922/1925 por Olga Dória, In: PIERSON, Donald. Estudos de Ecologia Humana - Leituras em Sociologia e Antropologia Social. Editora Livraria Martins Fontes, 1970, São Paulo.

BURGESS, Ernest. "As áreas urbanas” in An experiment in Social Science Research University of Chicago Press, Chicago, 1929. Traduzido por Mário Eufrásio.

CACHIONI, NERI, SIMSON (orgs). As Múltiplas Faces da Velhice no Brasil, Editora Alínea, Campinas, 2003.

CHALHOUB, Sidney. Cidade Febril. Cia das Letras, São Paulo, 2000.

CAMARANO, Ana Amélia (Org). Os novos idosos brasileiros: muito além dos 60? IPEA, Rio de Janeiro, 2004. 
CARRIÇO, José Marques. Legislação Urbanística e segregação espacial nos municípios centrais da Região Metropolitana da Baixada Santista. Dissertação de Mestrado da Faculdade de Urbanismo da Universidade de São Paulo (FAUUSP), São Paulo, 2002.

O Plano de Saturnino de Brito para Santos: urbanismo e planejamento urbano entre $o$ discurso $e$ a prática. Artigo publicado no site http://www.canaisdesantos.com.br, extraído em junho de 2006.

CASTELLS, Manuel. A Questão Urbana Ed. Paz e Terra, Rio de Janeiro, 2000.

COSER, Lewis A. "Tendências Americanas" in BOTTOMORE, T. \& NISBET, R. (orgs). História da Análise Sociológica. Zahar, Rio de Janeiro, 1980.

COWGILL, D.D. \& HOLMES, L.D. Aging and modernization. Apppleton-Century-Crofts, New York, 1972.

CUMMING, E.\& HENRY, W. Growing old. Basic Book, New York, 1961.

CUNHA, José M.P. da. Mobilidade Populacional e Expansão Urbana: o caso da Região Metropolitana de São Paulo. Tese de Doutorado apresentada ao Departamento de Ciências Sociais do Instituto de Filosofia e Ciências Humanas da Universidade Estadual de Campinas, 1994.

DA MATTA, Roberto. Carnavais Malandros e Heróis: para uma sociologia do dilema brasileiro. Editora Guanabara, Rio de Janeiro, 1990.

DEBERT, Guita, Grin. A Reinvenção do Envelhecer. Edusp FAPESP, São Paulo, 1999.

.Guita, Grin. "A antropologia e o estudo dos grupos e das categorias de idade" in BARROS, Miriam Moraes Lins. (org.) Velhice ou Terceira Idade?Ed. FGV, São Paulo, 2000, p.50-67.

DEBERT, Guita Grin. e SIMÕES, Júlio. Assis. "A aposentadoria e a invenção da Terceira Idade" in DEBERT, G. e SIMÕES, J. Antropologia e Velhice, Coleção Textos Didáticos, Gráfica do IFCH, Unicamp, 1998.

DESTRO, Gláucia. Corpos envelhecidos também dançam: uma análise das representações sociais do envelhecimento em Dance ao Entardecer, projeto municipal de Santos-SP Relatório Final de Iniciação Científica CNPq/PIBIC 2006.

EUFRÁSIO, Mário A. “A Delimitação da Sociologia na Escola de Chicago”, mimeo. São Paulo, 1995.

Mário A. Estrutura Urbana e Ecologia Humana: a escola de Chicago (19151940), Editora 34, São Paulo, 1999. 
FEATHERSTONE, Mike. "O Curso da vida: corpo, cultura e o imaginário no processo de envelhecimento" in DEBERT, G. e SIMÕES, J. Antropologia e Velhice, Coleção Textos Didáticos, Gráfica do IFCH, Unicamp, 1998.

FIREY, Walter. "Sentiment and Symbolism as ecological variables" - American Sociological Review, v.10, n² A, April 1945, pp.140-148.

FREITAS, Elizabete Viana. "Demografia e Epidemiologia do Envelhecimento" In PY, Lígia et al (orgs) Tempo de Envelhecer: percursos e dimensões psicossociais. Nau Editora, Rio de Janeiro, 2004.

FREITAS, Nilton. "A Aposentadoria Especial no Brasil”, artigo publicado no sítio do Instituto Nacional de Saúde no Trabalho -INST/CUT, 1998, disponível em http://www.instcut.org.br/pre01.htm.

FRUGOLI, Heitor Jr. Os shopping-centers de São Paulo e as formas de sociabilidade no contexto urbano. Dissertação de Mestrado do Departamento de Antropologia ad Faculdade de Filosofia Letras e Ciências Humanas da Universidade de São Paulo (FFLCH-USP), São Paulo, 1989.

. Centralidade em São Paulo: trajetórias, conflitos e negociações na metrópole. Cortez/Edusp, São Paulo, 2000.

GITAHY, Maria Lúcia Caira. Ventos do Mar: Trabalhadores do porto, movimento operário e cultura urbana em Santos, 1889-1914. Editora da Unesp e Prefeitura Municipal de Santos, São Paulo, 1992.

GOLDMAN, Sara Nigri. “As dimensões sócio-políticas do envelhecimento” In PY, Lígia et al (orgs) Tempo de Envelhecer: percursos e dimensões psicossociais . Nau Editora, Rio de Janeiro, 2004.

GOTTDIENER, Mark. A Produção do Espaço Urbano. Ed. Edusp, São Paulo, 1997

HADDAD, FILHO Elias Salim. A qualidade de vida como fator de desenvolvimento econômico sustentável: o caso da cidade de Santos. Dissertação de Mestrado em Gestão de Negócios pela Universidade Católica de Santos, 2004.

HOYT, Homer. The Structure and Growth of Residential Neighborhoods in American cities. United Government Printing Office, Washington, 1939.

JAKOB, Alberto E. "A Mobilidade Populacional Intra-Metropolitana da Baixada Santista o Período Pós-1970", in HOGAN, Daniel Joseph et al (orgs). Migração e Ambiente nas Aglomerações Urbanas Núcleo de Estudos da População/UNICAMP, 2001 
Análise sócio-demográfica da constituição do espaço urbano da Região Metropolitana da Baixada Santista no período 1960-2000. Tese de Doutorado defendida no Núcleo de Estudos da População da Universidade Estadual de Campinas (NEPO-UNICAMP), Campinas 2003.

LANNA, Ana Lúcia Duarte. Uma Cidade na Transição: Santos: 1870-1913, Editora Hucitec, São Paulo-Santos, 1996.

LAWS, Glenda. "The Land of Old Age': Society's Changing Attitudes toward Urban Built. Environments for Elderly People" in Annals of the Association of American. Geographers, 83(4), 1993, pp.672-693.

LEFEBVRE, Henri. The Production of Space, Oxford, Blackwell, 1991.

LENOIR, R. 'L'invencion du 'troisieme age': constituition du champ dês agents de gestion de la vieillesse.”. Actes de la Recherche en Science Sociales, N² 26, 1979.

LÔBO, Maurício Nunes. Imagens em Circulação: Os cartões postais produzidos na cidade de Santos pelo fotógrafo José Marques Pereira no início do século XX. Dissertação de mestrado em História do Instituto de Filosofia e Ciências Humanas da Universidade Estadual de Campinas, apresentada em 27 de agosto de 2004, Campinas.

MERRICK, Thomas William e GRAHAM, Douglas H. População e Desenvolvimento no Brasil: de 1800 até a atualidade. Zahar Editores, Rio de Janeiro, 1981.

MOTTA, Alda Britto: “A novas formas de sociabilidade de idosos - o caso de Salvador", In BAHIA. Análise \& dados, Salvador, vol. 10, n.4, p.129-137, março 2001. ."Sociabilidades possíveis: idosos e tempo geracional" in PEIXOTO, Clarice (org). Família e Envelhecimento. Editora da FGV, Rio de Janeiro, 2004.

NAXARA, Márcia Regina Capelari. Estrangeiro em sua própria terra: representações do brasileiro 1870 - 1920. Annablume - Fapesp, São Paulo, 1998.

NESE - Núcleo de Estudos Sócio-Econômicos da UNISANTA. Pesquisa de Emprego e Desemprego. Março 2003 a Setembro de 2006. Santos, 2006, disponível em http://www.nese.unisanta.br/

- Pesquisa de Orçamento Familiar, Santos, 2003, disponível em http://www.nese.unisanta.br.

NESE - Núcleo de Estudos Sócio-Econômicos da UNISANTA. Índice de Exclusão Social e inclusão Social - Santos-SP, disponível em http://www.nese.unisanta.br/

OLIVEIRA, Juliana Andrade. "Sociabilidade, estrutura urbana e o lugar social dos idosos", trabalho apresentado no Fórum "A Formação de Identidades Coletivas: comunidade, 
lugar e espírito", no Encontro ANPOCS 2004 em Caxambu, em 28 de outubro de 2004.

ORTIZ, Renato. Cultura e modernidade: a França no século XIX. São Paulo: Editora Brasiliense, 1991.

PACHECO, Jaime Lisandro. "Trabalho e Aposentadoria” In PY, Lígia et al (orgs.) Tempo de Envelhecer: percursos e dimensões psicossociais . Nau Editora, Rio de Janeiro, 2004.

PARK, Robert Erza Park. "A Cidade: Sugestões para Investigação do Comportamento Humano no Meio Urbano" in VELHO, Otávio Guilherme. O Fenômeno Urbano. Zahar Editores, Rio de Janeiro, 1976.

PEIXOTO, Clarice. Envelhecimento e Imagem. Annablume, Rio de Janeiro, 2000.

PY, Lígia et al (orgs) Tempo de Envelhecer: percursos e dimensões psicossociais. Nau Editora, Rio de Janeiro, 2004.

PEUCKER, Thomas K. "Joham Georg Kohl, a Theoretical Geographer of the $19^{\text {th }}$ Century" The Profession Geographer, vol XX, nº4 July 1968, p.247-250.

RODRIGUES, Olao. Cartilha da História de Santos. Instituto Histórico e Geográfico de Santos, Academia Santista de Letras e Ordem dos Velhos Jornalistas do Estado de São Paulo e União Brasileira de Escritores (Seção São Paulo). Santos, 1980.

RODRIGUES, Fabíola. "Por onde vão as Brisas Suaves do Sertão Paulista?” -População e Estruturação Urbana na constituição da cidade (im)possível - Votuporanga, um estudo de caso. Dissertação de Mestrado apresentada ao Programa de Pós-Graduação em Demografia do Instituto de Filosofia e Ciências Humanas da Universidade Estadual de Campinas (IFCH-UNICAMP), Campinas, 2004.

RUFATO, Marcela. Sucessão de Imigrantes no bairro do Bom Retiro. Comunicação no Encontro Anual do Centro de Estudos Rurais e Urbanas da Faculdade de Filosofia Ciências e Letras da Universidade de São Paulo, 2004.

SANTOS, Milton. O Espaço do Cidadão, Nobel, São Paulo, 1987.

SASSEN, Saskia. "New Frontiers of Urban Sociology" in British Journal Vol. N 51 (January/March 2000), p. 143-159, London School of Economics, 2000.

SIMMEL, Georg. "Sociabilidade: um exemplo de sociologia pura ou formal." In: MORAES FILHO, Evaristo(org.). Simmel. São Paulo: Ática, 1983. (Coleção Grandes Cientistas, 34). 
SIMÕES, Júlio Assis. "Provedores e militantes: imagens de homens aposentados na família e na vida pública" In: PEIXOTO, Clarice Ehlers (org.) Família e Envelhecimento, Editora FGV, Rio de Janeiro, 2004.

TELLES, Stella Maria Barberá da Silva. Idoso: Família, Trabalho e Previdência. Tese de doutorado defendida no do Departamento de Ciências Sociais do Instituto de Filosofia e Ciências Humanas da Universidade Estadual de Campinas, IFCH-UNICAMP, Campinas, 2003.

THOMAS, William e ZNANIECKI, Florian. Nota Metodológica, São Paulo, 2004. Organização, tradução e introdução de Mário Antonio Eufrásio.

VILAS BOAS, Sérgio. Santos: Centro Histórico, Porto e Cidade. Audichromo Editora, São Paulo, 2005

VILLAÇA, Flavio. "A Terra como Capital (ou a Terra-Localização)", in Espaço \& Debates, Ano V, n. ${ }^{\circ}$ 16, 1985.

VILLAÇA, Flávio. Espaço Intra-urbano no Brasil. Studio Nobel/FAPESP, São Paulo, 1998.

."Os Efeitos do Espaço sobre o Social” In: SOUZA, Maria Adélia et al (orgs) Metrópole e organização: conhecendo a cidade de São Paulo, CEDESP, São Paulo, 1999.

WAJNMAN, S.; OLIVEIRA, A. M. H. C.; OLIVERIA, E. L.de. A atividade econômica dos idosos no Brasil. In: CAMARANO, A. A. Muito além dos 60 anos: os idosos brasileiros. Rio de Janeiro: IPEA, 1999. p. 81-221. 